UNIVERSIDADE DE SÃO PAULO

FACULDADE DE FILOSOFIA, LETRAS E CIÊNCIAS HUMANAS

DEPARTAMENTO DE SOCIOLOGIA

PROGRAMA DE PÓS-GRADUAÇÃO EM SOCIOLOGIA

ALEXANDRE BARBOSA MARQUES

A Dominação do Espaço Urbano em Goiânia

SÃO PAULO 
UNIVERSIDADE DE SÃO PAULO

FACULDADE DE FILOSOFIA, LETRAS E CIÊNCIAS HUMANAS

DEPARTAMENTO DE SOCIOLOGIA

PROGRAMA DE PÓS-GRADUAÇÃO EM SOCIOLOGIA

\title{
A Dominação do Espaço Urbano em Goiânia
}

\author{
Alexandre Barbosa Marques \\ alexandrebarbosa@gmail.com \\ Dissertação apresentada para o Programa \\ de Pós-Graduação em Sociologia do \\ Departamento de Sociologia da \\ Faculdade de Filosofia, Letras e Ciências \\ Humanas da Universidade de São Paulo, \\ para a obtenção do título de Mestre em \\ Sociologia.
}

Orientador: Prof. Dr. Mário Antônio Eufrásio.

Palavras-chave: sociologia urbana, dominação, Bourdieu, Goiânia, espaço

SÃO PAULO 
Dedicado a Paulo Roberto Marques, Joana

Bortolini Franco e Mário Antônio Eufrásio 
Agradeço aos entrevistados pela gentileza em atender com toda a disposição e cuidado às minhas solicitações, à equipe dos arquivos da ADEMI e da SEPLAM, pela grande atenção recebida, e aos colegas da turma de 2010 e do grupo de sociologia urbana do CERU, pelas discussões e idéias compartilhadas. 


\section{Resumo}

A presente dissertação parte do postulado de que existe uma correspondência entre o espaço físico da cidade e o espaço social na cidade, de modo que os objetos dispostos no espaço físico da cidade podem representar a posição dos agentes no espaço social. Foi desenvolvido e aplicado para o caso de Goiânia um método descritivo e cartográfico de representação da estrutura urbana, para obter uma descrição dos padrões de disposição dos imóveis de alto padrão ao longo da história da cidade. A aplicação do método descritivo e cartográfico levou à hipótese inicial de que um processo histórico e específico de segregação sócio-espacial pode ser representado por este método porque há uma correspondência entre o espaço físico e o espaço social. Com o objetivo de explicar a hipótese inicial e, a partir dessa explicação, desenvolver um método propriamente sociológico de interpretação da análise da estrutura urbana, foi levantada uma série de questões cujo desenvolvimento levou à explicação da hipótese inicial. A explicação da hipótese inicial desenvolvida no trabalho foi sintetizada na forma da seguinte hipótese final: a disposição dos imóveis de alto padrão descrita pelo método descritivo e cartográfico é um efeito da dominação das áreas melhor qualificadas da cidade pela classe dominante do espaço urbano. O efeito da dominação garantiu a correspondência entre os imóveis de alto padrão e a classe dominante do espaço urbano. As permanências e mudanças nos padrões de disposição desses imóveis são as formas temporárias dessa correspondência, o que não modificou a lógica básica de segregação sócio-espacial. Ao fim do trabalho, foi apresentado um método propriamente sociológico para futura aplicação empírica e teste da hipótese final. 


\begin{abstract}
This thesis departs from the postulate that, in a city, social space is related to the physical one, in a way that objects disposed in the physical space might portray the position that agents assume in the social one. A cartographic and descriptive method was developed for the Goiânia city case, in order to achieve a description of the setting patterns of high standard properties along local history. Applying such a descriptive and cartographic method led to the initial hypothesis that a historical and specific segregation process can be represented by the developed method, as there is a relation between physical and social space. In order to explain the initial hypothesis and, from such explanation, develop a properly sociological analysis interpretation of the urban structure, a series of questions was raised, and this process led to the exposure of the starting hypothesis. The exposure was summarized in the following final hypothesis: the setting of high standard properties showed by the descriptive and cartographic method is an effect of the rule over the best qualified areas that the dominant class has over the urban space in Goiânia. The continuities and changes in the setting patterns of these properties are the temporary forms of such correspondence, and all of it has not modified the basic logics of social and space segregation. At the end of the project, a properly sociological method was introduced for future empirical application and for testing the final hypothesis.
\end{abstract}




\section{Conteúdo}

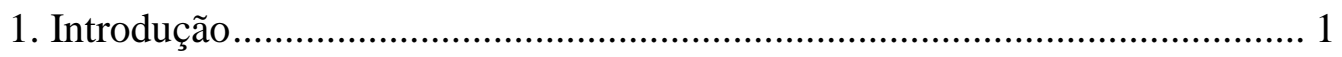

1.1. A Paris novecentista de As Regras da Arte ............................................. 1

1.2. O postulado de partida........................................................................... 3

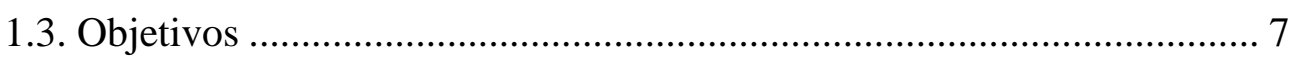

2. A questão do método descritivo ………………………………………….... 8

2.1. A motivação para a análise descritiva da estrutura urbana ...................... 8

2.2. A questão do método descritivo ............................................................. 9

2.3. Modelos cartográficos da estrutura urbana apropriados......................... 10

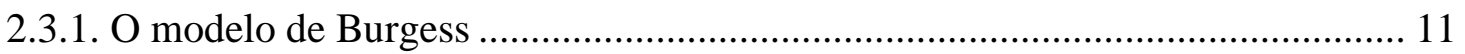

2.3.2. O modelo dos setores de círculo de Hoyt......................................................... 13

2.3.3. O modelo de Griffin e Preston .................................................................... 15

2.3.4. Os três modelos como escalas de representação da estrutura urbana ................. 17

2.4. O método descritivo e cartográfico ...................................................... 18

2.5. Exemplo de aplicação do método descritivo e cartográfico.................... 34

2.5.1. A hierarquia no planejamento original da cidade ............................................... 34

2.5.2. A estruturação da cidade até o início da década de quarenta ............................... 41

2.5.3. $\mathrm{O}$ adensamento nas décadas de quarenta e cinquenta ........................................ 50

2.6. Os resultados da aplicação do método .................................................. 68

3. A questão sociológica................................................................................. 76

3.1. A motivação para a interpretação sociológica da estrutura urbana ........ 76

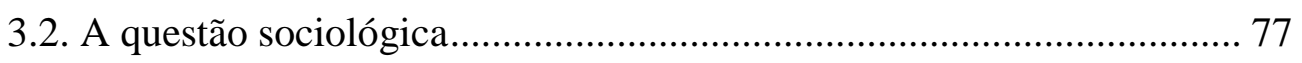

3.3. A hipótese de pesquisa ……………………………………………….... 83

4. A explicação da hipótese de pesquisa ……………………………………... 88

4.1. Algumas noções de Bourdieu ............................................................. 89

4.2. A primeira questão de pesquisa ……………………………………..... 93

4.3. A segunda questão de pesquisa …………………………………….... 97

4.3.1. Os critérios e os esquemas de qualificação ........................................................ 98

4.3.2. O sistema de qualificação.................................................................................. 103 


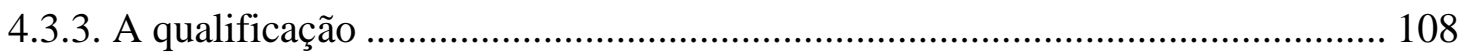

4.3.3. A distinção pela qualificação ....................................................................... 115

4.4. A terceira questão de pesquisa ......................................................... 116

4.5. A quarta questão de pesquisa ...................................................... 119

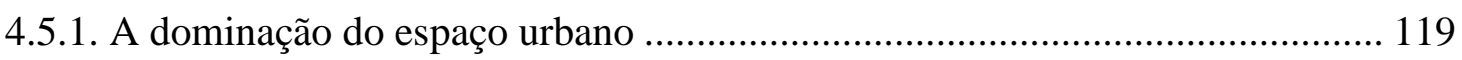

4.5.2. Os agentes estruturadores dominantes ........................................................ 123

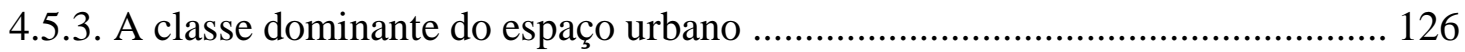

4.6. A quinta questão de pesquisa ............................................................ 131

4.6.1. A disposição sincrônica e diacrônica dos imóveis de alto padrão .................... 131

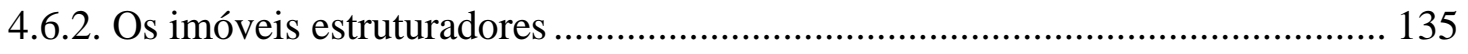

4.6.3. As forças centrífugas e centrípetas ............................................................ 138

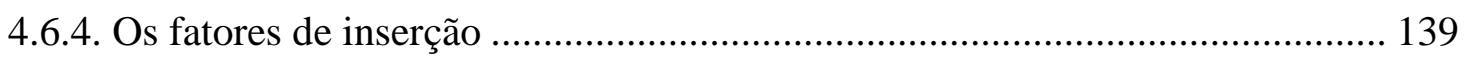

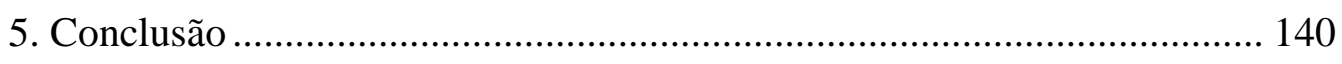

5.1. A explicação da hipótese de pesquisa ............................................. 140

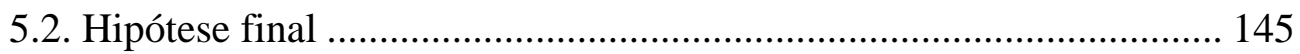

5.3. O método sociológico de análise da dominação do espaço urbano .... 145

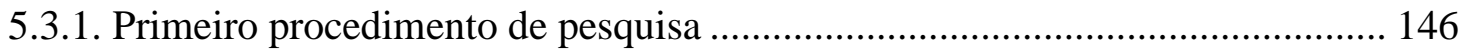

5.3.2. Segundo procedimento de pesquisa .............................................................. 147

5.3.3. Terceiro procedimento de pesquisa.............................................................. 147

5.3.4. Quarto procedimento de pesquisa ............................................................. 147

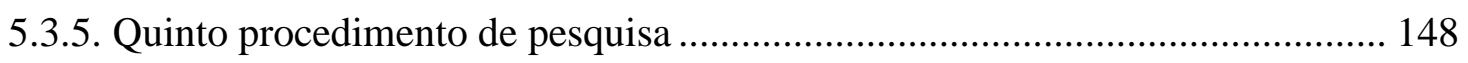

Referências bibliográficas .................................................................. 149

Apêndice: atividades de pesquisa........................................................... 158

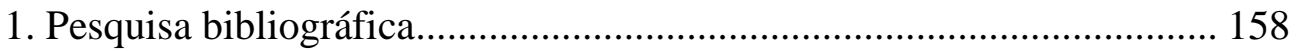

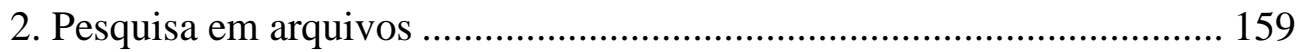

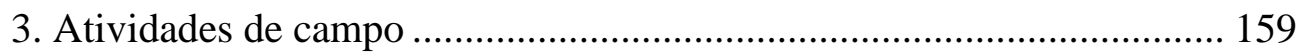

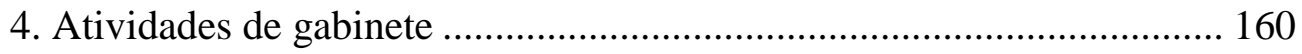




\section{Introdução}

\subsection{A Paris novecentista de As Regras da Arte}

Em sua leitura da obra A Educação Sentimental, de Gustave Flaubert, Pierre Bourdieu destaca que o romancista, ao estabelecer "os dois pólos do campo do poder", instaura "as condições de uma espécie de experimentação sociológica” (Bourdieu 2002: 24). A narrativa de Flaubert, sob a ótica de Bourdieu, trata de cinco adolescentes lançados em um "campo do poder" - "como partículas em um campo de forças" - e de suas trajetórias "nesse espaço", que "serão determinadas pela relação entre as forças do campo e sua [dos personagens] inércia própria" (idem). O “campo do poder" é um "campo de forças possíveis, que se exercem sobre todos os corpos que nele podem entrar” (ibid.). É um “meio" em que "se exercem forças sociais, atrações ou repulsões, que encontram sua manifestação fenomenal sob a forma de motivações psicológicas tais como o amor ou a ambição" (ibid.). Também é "um campo de lutas, e talvez, a esse título, comparado a um jogo" (ibid.). Nesse "campo de lutas", as "disposições" incorporadas pelos agentes - incluindo aí a elegância, a naturalidade e a beleza -, e o "capital", "sob suas diversas formas, econômica, social, cultural", constituem os "trunfos que vão comandar a maneira de jogar e o sucesso no jogo" (ibid.). O que está em jogo é o "domínio" de uma posição a ser mantida ou conquistada, e os jogadores em questão se diferenciam em relação aos seus trunfos e à sua "vontade de vencer" (ibid.: 24-25).

Esse deslocamento dos agentes em luta através de posições ocupadas em um espaço social apresenta um paralelo com os deslocamentos e posições ocupadas pelos personagens no espaço físico de Paris. Há, na Paris novecentista de A Educação Sentimental, de acordo com Bourdieu, um triângulo cujos vértices estão ligados a espaços que representam "mundos" distintos: o mundo dos negócios (a rua Chaussée D’Antin), o mundo da arte (o bairro de Montmartre) e o mundo dos estudantes (Quartier Latin) (ibid.: 56). A estrutura representada por esse triângulo "não é outra que 
não a do espaço social de A educação sentimental" (ibid.) ${ }^{1}$. Existem também relações de oposição entre os personagens associados aos dois pólos desse espaço social representado no espaço físico. Assim, os habitantes e freqüentadores do Quartier Latin, lugar de boemia e diversões, se opõem aos habitantes do Saint-Germain, "centro do ascetismo aristocrático"; já na Chaussée D’Antin e ruas circunvizinhas, vivem os membros da "nova fração dirigente da classe dominante", que se opõem tanto aos moradores de Montmartre, "lugar de residência oficial dos artistas de sucesso", quanto aos ocupantes do reduto da antiga aristocracia no Saint-Germain (ibid.: 57-58). Construindo ali grandes mansões, os moradores da Chaussée D'Antin recriam “os sinais do antigo padrão de vida do 'faubourg' Saint-Germain” (ibid.: 58). Para Bourdieu, essas construções são o produto de uma "readaptação social que se traduz por uma translação espacial" (ibid.).

Ao longo do tempo, os personagens de Flaubert mudam de domicílio e trocam seus locais de frequiência social. Esses movimentos são representados a partir de uma lógica hierárquica: “nesse 'espaço estruturado e hierarquizado', as trajetórias sociais ascendentes e descendentes distinguem-se claramente do sul para o noroeste, quanto às primeiras, e do oeste ao leste e/ou do norte ao sul, quanto às segundas" (ibid.: 59). Portanto, na cidade de Paris, onde "jogam” Frédéric e os outros jovens personagens, há uma associação simbólica entre o espaço físico e o espaço social, de modo que o espaço físico se associa a "mundos" específicos. Essa associação é também uma associação de sinais de posições distintas, de modo que a posição - de local de moradia e de locais de convívio social - de um agente no espaço físico pode representar a posição dos mesmos agentes no espaço social, o que permite a Bourdieu traçar as trajetórias dos indivíduos no espaço físico e indicar, assim, suas trajetórias sociais, quer sejam ascendentes ou decadentes $^{2}$.

\footnotetext{
${ }^{1}$ Além do referido triângulo, existem ainda áreas não frequentadas pelos personagens principais: o bairro da antiga aristocracia (Saint-Germain), e as áreas de moradias das "classes populares". O "universo" representado pelo triângulo é definido por uma "dupla relação de oposição, jamais evocada", com a antiga aristocracia do faubourg Saint-Germain, e com as "classes populares". (Bourdieu 2002: 56).

${ }^{2}$ A representação se dá na medida em que um sinal ou um símbolo possui a qualidade de se referir a algo que não ele próprio. É desse modo que duas famílias (Arnoux e Dambreuse) "funcionam como símbolos encarregados de marcar e de representar posições pertinentes ao espaço social" (Bourdieu 2002: 19), e que as trajetórias dos personagens no espaço físico de Paris representam suas trajetórias no espaço social.
} 


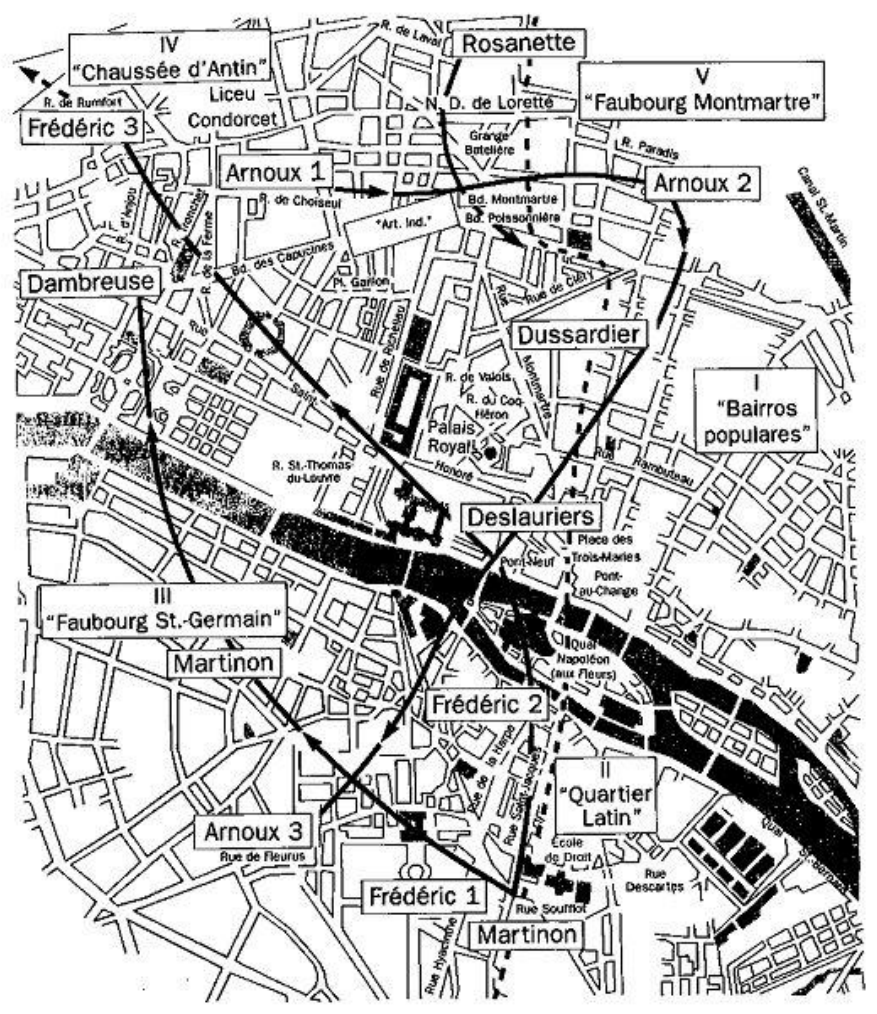

Figura 1. Trajetórias residenciais dos personagens de Flaubert traçadas sobre o mapa de Paris. As trajetórias residenciais representam as trajetórias sociais dos mesmos personagens. Fonte: Bourdieu 2002.

No que diz respeito a esta pesquisa, na interpretação bourdieana da Paris novecentista de Flaubert interessam particularmente as propriedades que são atribuídas ao espaço físico de Paris, cuja associação forma o postulado de partida desta pesquisa: (1) o espaço físico pode representar o espaço social; (2) existe uma correspondência entre o espaço físico e o espaço social.

\subsection{O postulado de partida}

Em As Regras da Arte, Bourdieu desenvolve sua apreciação do valor sociológico da obra de Flaubert orientando-a para a apresentação de uma topografia social $^{3}$, e a correspondência do espaço físico com o espaço social possui uma

3 Como pode ser observado nesses dois exemplos: (a) "Se A educação sentimental, história necessária de um grupo cujos elementos, unidos por uma combinatória quase sistemática, estão sujeitos ao conjunto das forças de atração ou de repulsão que exerce sobre eles o campo do poder, pode ser lida como uma história, é que a estrutura que organiza a ficção, e que fundamenta a ilusão de realidade que ela produz, dissimula-se, como na realidade, sob as interações entre pessoas, que ela estrutura". (Bourdieu 2002: 28); (b) "Com efeito, A educação sentimental reconstitui de maneira extraordinariamente exata a estrutura do mundo social na qual foi produzida e mesmo as estruturas mentais que, modeladas por essas estruturas sociais, são o principio gerador da obra na qual essas estruturas se revelam. Mas ela o faz com os meios que lhe são próprios, ou seja, dando a ver e a sentir, em exemplificações ou, melhor, evocações no sentido forte de encantações capazes de produzir efeitos, especialmente sobre os corpos, pela 'magia 
importância apenas secundária. Mas, ainda que continue secundária aos interesses do autor em suas outras obras, essa correspondência não se resume ao que foi encontrado em Flaubert. A correspondência entre o espaço físico e o espaço social também é observada pelo autor na França no final do século XX, mais de um século depois de $A$ Educação Sentimental. É possível constatá-la em A Miséria do Mundo, obra na qual Bourdieu publicou um breve texto dedicado especificamente à localização de agentes e objetos no espaço físico, nomeado "Efeitos do Lugar".

Nesse texto, Bourdieu define o "lugar" como "o ponto do espaço físico onde um agente ou uma coisa se encontra situado, tem lugar, existe" (Bourdieu 1999: 160). O lugar dos agentes e das coisas pode ser entendido como "localização", "sob um ponto de vista relacional”, ou como "posição”, “como graduação em uma ordem”. Trata-se, em última instância, da "superfície e o volume que um indivíduo ou uma coisa ocupa no espaço físico" (idem). Se não há aqui um conceito mais geral de "espaço", a não ser enquanto espaço produzido ou significado, e definido em termos de posição e de localização, há, no entanto, a noção de que um lugar é um espaço ocupado por um indivíduo ou coisa e que, por isso, poderá ser relacionado e classificado.

Os agentes são caracterizados ou classificados em relação à sua inserção em um espaço social. Também são aí classificadas as coisas apropriadas e utilizadas pelos agentes, que se convertem em suas propriedades ${ }^{4}$. É justamente a localização dos objetos no espaço social e sua apropriação pelos agentes que dá ao espaço físico ocupado a possibilidade de representar simbolicamente o espaço social, como ocorre em A Educação Sentimental. O espaço físico, mais ainda, naturaliza as hierarquias sociais:

A estrutura do espaço social se manifesta, assim, nos contextos mais diversos, sob a forma de oposições espaciais, o espaço habitado (ou apropriado) funcionando como uma espécie de simbolização espontânea do espaço social. Não há espaço, em uma sociedade hierarquizada, que não seja hierarquizado e que não exprima as hierarquias e as distâncias sociais, sob uma forma (mais ou menos) deformada e, sobretudo, dissimulada pelo efeito de naturalização que a inscrição durável das realidades sociais no mundo natural acarreta: diferenças produzidas pela lógica histórica podem, assim, parecer surgidas da natureza das coisas (basta pensar na idéia de "fronteira natural") (ibid. Grifos do autor.).

evocativa' de palavras capazes de 'falar a sensibilidade' e de obter uma crença e uma participação imaginária análoga às que concedemos ordinariamente ao mundo real”. (idem: 48).

4 "Os agentes sociais que são constituídos como tais em e pela relação com um espaço social (ou melhor, com campos) e também as coisas na medida em que elas são apropriadas pelos agentes, portanto constituídas como propriedades, estão situados num lugar do espaço social que se pode caracterizar por sua posição relativa aos outros lugares (acima, abaixo, entre, etc.) e pela distância que o separa deles". (Bourdieu 1999: 160). 
Trata-se de uma correspondência relativa entre o espaço social e o espaço físico, na qual a "posição de um agente no espaço social se exprime no lugar do espaço físico em que está situado", condição importante para a distinção entre as diferentes classes e frações de classe, já que "o consumo mais ou menos ostentatório do espaço é uma das formas por excelência de ostentação do poder” (ibid.: 161). Essa correspondência leva, para Bourdieu, o espaço ocupado à condição de "espaço social reificado (isto é, fisicamente realizado ou objetivado)" (ibid.).

Bourdieu esclarece sua concepção a respeito do espaço físico como espaço social reificado ao afirmar que "as grandes oposições sociais objetivadas no espaço físico", tendem a "se reproduzir nos espíritos e na linguagem sob a forma de oposições constitutivas de um princípio de visão e de divisão, isto é, enquanto categorias de percepção e de apreciação ou de estruturas mentais" (ibid.: 162). O espaço físico apropriado exerce uma série de coerções, ou "chamadas à ordem", que "são uma das mediações através das quais as estruturas sociais se convertem progressivamente em estruturas mentais e em sistemas de preferências" (ibid.). Essa característica do espaço físico apropriado, que contribui para a "incorporação insensível das estruturas da ordem social", se faz ainda através da "experiência prolongada e indefinidamente repetida das distâncias espaciais nas quais se afirmam distâncias sociais", e é "através dos deslocamentos e dos movimentos do corpo que essas estruturas sociais convertidas em estruturas espaciais e assim naturalizadas organizam e qualificam socialmente como ascensão e declínio" (ibid.). A "aproximação ou distanciamento em relação a um lugar central e valorizado" é um exemplo dessa mediação (ibid.).

Como resultado da apropriação diferenciada do espaço físico pelos agentes sociais, há as "concentrações dos bens mais raros e de seus proprietários em certos lugares do espaço físico", que "se opõem assim, em todos os aspectos, aos lugares que agrupam principalmente e por vezes exclusivamente os mais carentes" (ibid.: 161.). Essas áreas de concentração dos bens mais raros abrigam as moradias dos agentes bem situados no espaço social e também diversas atividades comerciais "que têm em comum ocupar posições elevadas (portanto, homólogas entre si) em seus campos respectivos”, e que "não podem ser compreendidos no que eles têm de mais específico a não ser que o coloquemos em relação com comércios situados no mesmo campo, em posições inferiores, mas em outras regiões do espaço físico" (ibid.).

O espaço físico, ao ser assim apropriado, se torna relativamente homólogo ao espaço social. As posições e as transformações nas posições dos agentes no espaço 
social, decorrentes das lutas por posições elevadas no espaço social, exercem efeitos no espaço físico, na medida em que os agentes se distribuem no espaço físico relativamente de acordo com sua posição no espaço social, como ocorre em A Educação Sentimental, e como segue nessa passagem de Meditações Pascalianas:

\begin{abstract}
O espaço social tende a se reproduzir, de maneira mais ou menos deformada, no espaço físico, sob a forma de um certo arranjo de agentes e propriedades. Por conseguinte, quaisquer divisões e distinções do espaço social (alto/baixo, esquerda/direita etc.) se exprimem real e simbolicamente no espaço físico apropriado como espaço social reificado (por exemplo, na oposição entre os bairros elegantes, (...), e os bairros populares ou os subúrbios). Esse espaço é definido pela correspondência, mais ou menos estreita, entre uma certa ordem de coexistência (ou de distribuição) dos agentes e uma certa ordem de coexistência (ou de distribuição) das propriedades. Em consequência, não existe alguém que não seja caracterizado pelo lugar em que está situado de maneira mais ou menos permanente ("não ter eira nem beira" ou não possuir 'domicílio fixo' é ser desprovido de existência social; ser da 'alta sociedade' é ocupar as altas esferas do mundo social). Também caracterizado pela posição relativa, logo pela raridade, geradora de rendas materiais ou simbólicas, de suas localizações temporárias (por exemplo, os lugares de honra e quaisquer prerrogativas de quaisquer protocolos) e sobretudo permanentes (endereços privado e profissional, lugares permanentes, pontos de vista insólitos, exclusividades, prioridades, etc.). Caracterizado enfim pelo lugar que assume, que ocupa (de direito) no espaço por meio de suas propriedades (casas, terras etc.), que são mais ou menos 'devoradoras de espaço' (space consuming) (Bourdieu 2001: 165).
\end{abstract}

Essa idéia de correspondência entre a distribuição dos agentes e a distribuição de suas propriedades fornece a chave para a compreensão de que é justamente essa correspondência relativa entre as estruturas que fornece ao espaço físico a propriedade de simbolizar o espaço social. É possível representar o espaço social através do espaço físico com base nessa correspondência, é possível captar efeitos de ordem sociológica a partir de uma descrição da estrutura física, porque há uma correspondência relativa entre o espaço urbano e o espaço social. Essa compreensão é uma proposta básica apresentada por esta pesquisa, de modo que o postulado de partida adotado pode ser assim expresso: o espaço físico pode representar o espaço social com base em uma relativa correspondência entre o espaço físico e o espaço social.

Se tomar, ainda com base nessa noção de correspondência entre os espaços, uma noção de estrutura urbana como uma estrutura da distribuição de agentes e propriedades em um recorte espacial delimitado e classificado como urbano, e tomar a noção de espaço social como uma estrutura de posições sociais, então posso apresentar o postulado de que a estrutura urbana pode representar a estrutura social com base em uma relativa correspondência entre a estrutura urbana e a estrutura social. 


\subsection{Objetivos}

Esta pesquisa realiza uma investigação sobre a segregação sócio-espacial na cidade de Goiânia. A segregação sócio-espacial é compreendida a partir do postulado de partida, que afirma a existência de uma correspondência entre a disposição dos elementos no espaço físico e as posições de agentes no espaço social, de modo que a posição dos elementos no espaço físico pode simbolizar a posição dos agentes no espaço social ${ }^{5}$. No entanto, é difícil encontrar um modo eficaz para explicar essa correspondência e conectar satisfatoriamente o espaço físico e o espaço social. Superar essa lacuna e obter alguma compreensão da conexão entre o objeto e a agência é o principal desafio para esta pesquisa, e determinará o grau de sucesso na busca de gerar uma contribuição significativa para a sociologia da cidade e das relações sócioespaciais.

O objetivo geral desta pesquisa pode ser expresso da seguinte maneira: apresentar a proposta de um método sociológico de interpretação da estrutura urbana que seja capaz de esclarecer a relativa correspondência entre o espaço físico e o espaço social, fundamentado em uma explicação de como o espaço físico pode representar o espaço social com base nessa correspondência.

Para alcançar esse objetivo geral a pesquisa lida com dois problemas. Em primeiro lugar, a pesquisa busca explicar a lógica da correspondência postulada e, em segundo lugar, apresentar uma metodologia aplicável a um estudo empírico e sociológico. Assim, o objetivo geral pode ser divido em dois objetivos específicos: $O$ primeiro objetivo específico é esclarecer a relativa correspondência entre o espaço físico e o espaço social e explicar como o espaço físico pode representar o espaço social com base nessa correspondência. Tal explicação deverá ser apresentada na forma de uma hipótese final. O segundo objetivo é apresentar um método de estudo empírico propriamente sociológico para testar, a posteriori, a hipótese final.

Para alcançar esses objetivos, foram levantadas duas questões, a questão do método descritivo, e a questão sociológica. Como a questão sociológica levará ao

\footnotetext{
${ }^{5} \mathrm{Na}$ verdade, os elementos sociais associados a elementos espaciais podem ser e de fato são utilizados formal e informalmente para classificar indivíduos e grupos em termos de estratificação social, como na contagem de eletrodomésticos ou do número de automóveis por domicílio em uma pesquisa censitária, por exemplo. Além disso, o próprio conceito de "segregação sócio-espacial" exprime a idéia de correspondência entre grupos sociais e grupos de elementos da estrutura urbana.
} 
desenvolvimento da hipótese de pesquisa, foi levantada uma terceira questão, acerca de como explicar a hipótese da pesquisa ${ }^{6}$.

\section{A questão do método descritivo}

\subsection{A motivação para a análise descritiva da estrutura urbana}

A motivação básica para a realização de uma análise descritiva da estrutura urbana de Goiânia se deve a duas fontes de leitura. Em primeiro lugar, os autores norteamericanos da geografia e da economia urbanas do pós-guerra, principalmente Homer Hoyt, Griffin e Griffin e Preston, cuja leitura e exposição de textos em seminários faz parte das atividades exercidas pelo grupo de sociologia urbana do $\mathrm{CERU}^{7}$, orientado pelo professor Mário Eufrásio. Esses autores desenvolveram métodos e modelos de análise da estrutura urbana que podem ser considerados um desenvolvimento do modelo de Burgess, o clássico modelo dos círculos concêntricos, criado na década de 20. Em segundo lugar, a obra O Espaço Intra-Urbano no Brasil, de Flávio Villaça. Nesse livro, o autor realiza uma análise da estrutura urbana de seis metrópoles brasileiras - São Paulo, Rio de Janeiro, Belo Horizonte, Salvador, Recife e Porto Alegre - que mostra como padrões estruturais similares àqueles observados pelos autores norte-americanos, referidos acima, podem também ser encontrados nas metrópoles brasileiras. Esses padrões similares se referem, em geral, à concentração e desconcentração de tipos e qualidades de imóveis, objetos móveis e agentes no solo urbano; e, em particular, à disposição dos imóveis, cuja fixação no solo oferece uma especificidade para a observação empírica, que pode ser adequada para captar processos estruturais de longa duração. O modelo geral de representação da estrutura urbana em setores de círculo ${ }^{8}$, desenvolvido por Homer Hoyt, é adaptado por Villaça para representar a estrutura urbana das metrópoles brasileiras.

\footnotetext{
${ }^{6}$ Que não deve ser confundida com a hipótese final.

${ }^{7}$ Centro de Estudos Rurais e Urbanos - FFLCH - USP.

${ }^{8}$ Em Goiânia, muitos bairros são conhecidos como "Setores", como Setor Central, Setor Oeste, Setor Sul, Setor Marista ou Setor Bueno. Isso pode gerar confusão ao me referir a "setor" no sentido definido por Hoyt e usado também por Villaça e Griffin \& Preston, de setor radial de um círculo que representa graficamente uma área urbana ou cidade. Assim, para denominar um bairro goianiense, usarei "Setor" com inicial maiúscula, e para denominar um setor de círculo, utilizarei o termo com inicial minúscula.
} 

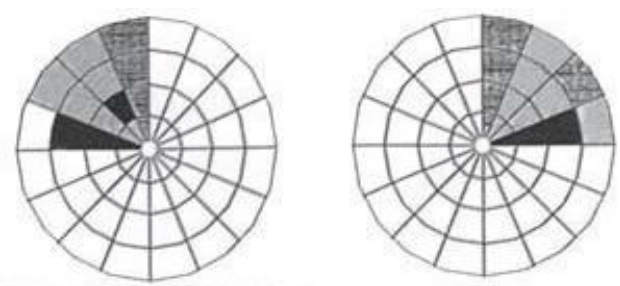

RIO DE JMREIRO(INCLUS NE NTEROI)
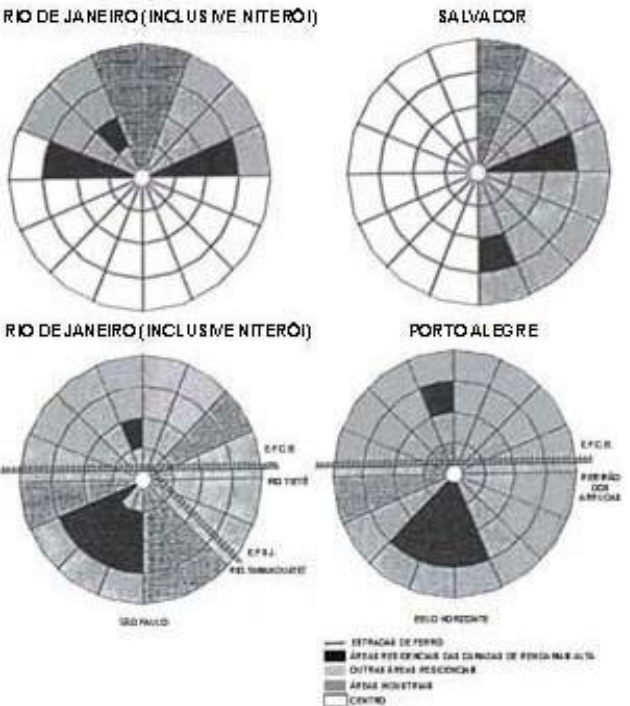

Figura 2. Aplicação do modelo desenvolvido por Homer Hoyt às metrópoles brasileiras, de acordo com Flávio Villaça. No alto, está representada a cidade do Rio de Janeiro, à esquerda, e Salvador, à direita. No centro, o Rio de Janeiro (incluindo Niterói, nesse caso), à esquerda, e Porto Alegre, à direita. Abaixo, São Paulo, à esquerda, e Belo Horizonte, à direita. Estão representadas duas categorias de áreas residenciais. $\mathrm{Na}$ cor mais escura, as áreas residenciais de mais alta renda. $\mathrm{Na}$ cor mais clara, as outras áreas residenciais. A cor intermediária representa as áreas industriais, que tiveram uma tendência histórica de desenvolvimento ao longo dos eixos ferroviários principais, também representados nos modelos. Em branco, estão as áreas ocupadas pelo mar nas cidades litorâneas e pela Lagoa dos Patos, em Porto Alegre. Fonte: Villaça 2001 (Adaptado por Oliveira 2005).

\subsection{A questão do método descritivo}

Em Goiânia, essas leituras orientaram a observação da distribuição dos tipos e qualidades dos usos do solo urbano, como uma atividade inicial desta pesquisa. Foi então constatado que padrões similares de configuração dos elementos urbanos também ocorreram ali. Os imóveis de alto padrão se concentram em áreas específicas da cidade e, além disso, essas concentrações de usos do solo de alto padrão progrediram no espaço através do tempo, em um processo de longa duração que seguiu a mesma orientação geral em direção ao sul.

Mas, para realizar uma descrição mais sistemática da estrutura urbana de Goiânia, foi preciso encontrar ou adaptar um método adequado para tal. Por isso, foi necessário adaptar ou desenvolver um método descritivo aplicável nas condições específicas desta pesquisa. 
Como desenvolver um método viável - e não ainda propriamente sociológico para fins de análise da estrutura urbana? Essa questão se levanta porque os referidos trabalhos, que levaram ao desenvolvimento de modelos da estrutura urbana e de métodos para sua análise, são resultados de grandes projetos de pesquisa, com extensa gama de dados disponíveis. No caso desta pesquisa, todo o trabalho empírico foi fruto de esforços individuais, o que resultou necessariamente em adaptações no método de pesquisa utilizado. De um modo geral, pode-se dizer que o método de pesquisa individual sacrificou a precisão na capacidade de delimitação dos objetos, que caracteriza os trabalhos dos geógrafos e economistas norte-americanos que desenvolveram os métodos de análise da estrutura urbana que inspiraram esta pesquisa. Esse sacrifício se fez necessário pela incapacidade de realizar um levantamento detalhado de dados acerca de todas as edificações qualificadas como "de alto padrão", ao longo do meu recorte temporal. Trata-se, assim, do desenvolvimento de um método de pesquisa qualitativo, não apenas no sentido de que utiliza dados diversos para qualificar o objeto em diferentes padrões, mas também porque é necessário um método que se adapte à dependência de fontes variadas para a tipificação e a qualificação dos elementos urbanos.

Assim, a questão do método descritivo pode ser expressa nos seguintes termos: como desenvolver um método para mapear elementos da estrutura urbana que seja viável diante das condições de pesquisa?

\subsection{Modelos cartográficos da estrutura urbana apropriados}

Antes de apresentar o método descritivo adotado por esta pesquisa, faz-se necessária uma sumária apresentação de meu entendimento acerca de três modelos de explicação da estrutura urbana, os modelos de Burgess, Hoyt e de Griffin e Preston. Acredito que esses três modelos podem ser entendidos como complementares, na medida em que representam a estrutura sócio-espacial urbana em escalas diferentes e, assim, o modelo mais abrangente contém em si o modelo menos abrangente.

Mais importante, porém, é o convite ao leitor para atravessar os limites dos diferentes campos de compreensão acerca da cidade. Quando se observa os modelos da estrutura urbana, deve-se ter em mente que eles buscam representar a disposição de unidades reconhecíveis no espaço urbano. Essa atividade de representação é encontrada também em outras categorizações da cidade, que lidam com elementos identificados por 
termos coletivamente reconhecidos - tais como casas, ruas, praças ou bairros. Os termos utilizados em diversos esquemas de classificação da cidade podem ser associados por correspondência: o setor de alta renda de Hoyt pode corresponder à zona sul do Rio de Janeiro; o centro expandido e a zona de expansão urbana dos planos diretores podem corresponder ao centro e à periferia da linguagem cotidiana. Isso quer dizer que existem semelhanças entre diferentes formas de descrição da cidade: os modelos acadêmicos da estrutura urbana que serão apresentados podem guardar semelhanças com os planospilotos das "cidades planejadas"; também podem guardar semelhanças com a categorização praticada nos planos diretores e nos projetos de intervenção urbana; com os critérios de atribuição de valor dos manuais de especialistas em avaliação imobiliária; com os mapas sócio-econômicos das cidades, produzidos pela plotagem de dados censitários; e ainda com as categorizações praticadas na publicidade, na imprensa e nos discursos informais do cotidiano.

O que se propõe aqui é um tratamento instrumental dos modelos de representação da estrutura urbana, que devem ser concebidos e utilizados como ferramentas de pesquisa empírica, para representar em mapas os dados obtidos de fontes diversas. Essas fontes podem se referir aos seguintes tipos de dados: (a) os tipos diferentes de usos do solo, (b) os diferentes valores monetários do solo e das edificações urbanas, (c) a densidade horizontal e vertical de ocupação do espaço urbano, e (d) o volume dos fluxos de circulação de pessoas, mercadorias e veículos. Por essa qualidade de condensação da representação dos dados na forma de mapas, foi dado o nome de "cartográficos" a esses modelos da estrutura urbana. Pretendo com isso desassociar os modelos da estrutura urbana de qualquer referência teórica prévia que os tenha moldado.

\subsubsection{O modelo de Burgess}

O modelo clássico dos círculos concêntricos da estrutura urbana de Chicago, desenvolvido por Ernst Burgess (cf. Burgess 1970: 363), se aplicado ao caso de Goiânia e de outras cidades brasileiras, é útil para o entendimento do padrão característico de segregação centro-periferia, como foi mostrado por Villaça (2001:113). Uma aplicação básica desse modelo no Brasil resultaria - geralmente, segundo suponho - em uma 
representação bem diferente da original, pois apresentaria apenas dois círculos concêntricos, ao invés de cinco, como no modelo de Chicago ${ }^{9}$.

É possível pensar na concepção de Burgess como um modelo que representa o crescimento geral da cidade através de uma relação entre a demografia e o valor do solo, de modo a apresentar um gradiente duplamente informado, que é ao mesmo tempo um gradiente de valores do solo e de densidade de ocupação do solo ${ }^{10}$. A pressão econômica exercida pelos usos do solo característicos das áreas mais centrais da cidade, os usos não residenciais, seria um importante fator de crescimento urbano, ao lado do desejo dos consumidores por novos e atraentes lançamentos imobiliários ${ }^{11}$.

${ }^{9} \mathrm{O}$ que não descarta a possibilidade de representações mais elaboradas e que resultem em um maior número de anéis concêntricos, principalmente para períodos de rápido crescimento urbano.

${ }^{10}$ Como pode ser observado nessa sequência de passagens: "Uma hipótese compartilhada por Burgess, por Park e por McKenzie é a de que 'os valores do solo se elevam com o movimento e o aumento da população' (Park, 1929-C, p. 190). Para Park, 'o aumento dos valores do solo em qualquer parte da comunidade serve para ocasionar, por sua vez, uma redistribuição da população na comunidade como um todo (...)' (ibid.) (...) 'Assim, parece que os valores do solo, que são eles próprios em larga medida um produto dos agregados de população, operam no decorrer do tempo para dar a este agregado, dentro dos limites da comunidade, uma distribuição organizada e um padrão característico. Sob a pressão dos valores do solo no centro, as cidades tendem a assumir a forma de uma série de círculos concêntricos, cada um dos quais circunscreve uma área de mobilidade decrescente e valores do solo em diminuição. Se os valores do solo mais elevados estão na área de compras de varejo, eles normalmente se localizarão no ponto em que, no decorrer das vinte e quatro horas, o maior número de pessoas se encontra e passa' (ibid., p. 191)" (Eufrásio 1999: 147-148).

““A mobilidade é talvez o melhor índice do estado de metabolismo da cidade' (p. 59). (...) 'As variações nos valores do solo (já que refletem o movimento), especialmente onde correlacionadas às diferenças nos aluguéis, oferecem a melhor medida de mobilidade, e assim, de todas as mudanças que ocorrem na expansão e no crescimento da cidade' (p. 610). (...) 'As variações nos valores do solo (já que refletem o movimento), especialmente onde correlacionadas às diferenças nos aluguéis, oferecem a melhor medida da mobilidade e, assim, de todas as mudanças que ocorrem na expansão e no crescimento da cidade' ( $p$. 61)". (Eufrásio 1999: 89).

“'O movimento significativo para o crescimento é aquele que implica numa mudança do movimento em resposta a um novo estímulo ou nova situação' que 'é chamado de mobilidade' (p. 58). (...) 'Os mais elevados valores do solo em Chicago estão no ponto de maior mobilidade da cidade, na esquina das ruas State e Madison, no Loop; por mais de dez anos, os valores do solo no Loop estiveram estacionados, mas no mesmo período dobraram, quadruplicaram e mesmo sextuplicaram nas esquinas estratégicas dos loops-satélites, um índice preciso das mudanças que ocorreram (...)' (p. 61)”. (Eufrásio 1999: 90).

11 “(...) Há, nesse reagrupamento, no entanto, uma hierarquia de fatores, pois o fator ao qual Burgess atribui o papel principal na formação do padrão da cidade é (...) 'o da extensão radial [crescimento radial para fora], que dá a estrutura urbana básica da cidade' (...) e 'é devida em parte à pressão do comércio e da indústria, e em parte ao impulso de se transferir de residência: o comércio e a indústria, à medida em que se desenvolvem, se estendem para fora desde o centro da cidade e penetram entre as residências; e as famílias respondem aos apelos de distritos residenciais mais atraentes, cada vez mais afastados do centro da cidade' (1928, p. 51) (p. 167). (...) 'Se a extensão radial fosse o único fator que afetasse o crescimento das cidades americanas, toda cidade do país exibiria uma exemplificação perfeita dessas zonas" (1928, p. 53 e 1929, p. 118).” (Eufrásio 1999: 168). 


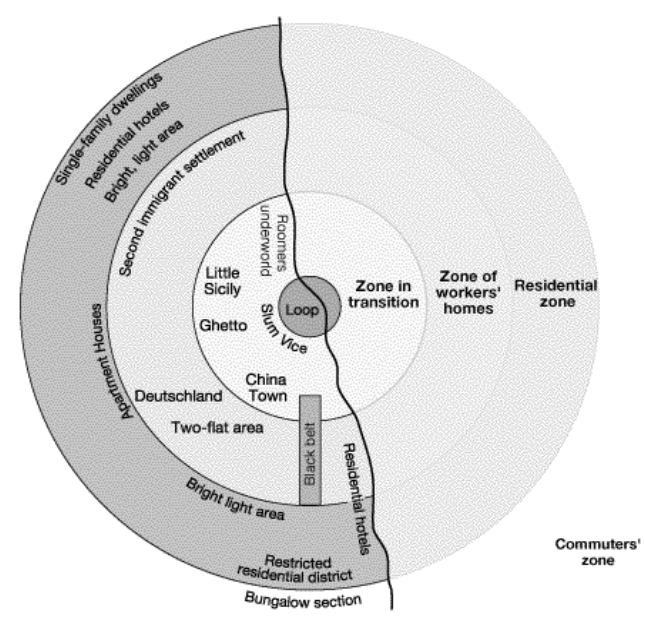

Figura 3. O modelo de Burgess em sua configuração original. Fonte: www.geographyfieldwork.com

\subsubsection{O modelo dos setores de círculo de Hoyt}

Após defender sua tese de doutorado em economia com uma pesquisa sobre o mercado imobiliário de Chicago, Homer Hoyt se torna (1934) o chefe do setor de economia habitacional da agência governamental criada para financiar a compra da casa-própria, a Federal House Administration (Eufrásio 2009: 25). Nessa instituição, Hoyt $^{12}$ pôde levantar os dados necessários para a produção de seu mais conhecido trabalho: The Structure and Growth of Residential Neighborhoods in American Cities. De acordo com Eufrásio:

O estudo resultante lhe permitiu reformular um importante aspecto da teoria do sociólogo Ernest W. Burgess da estrutura urbana em cinco zonas circulares concêntricas: para Hoyt, o crescimento da cidade ocorreria por setores ao longo das vias de transporte mais rápido existentes, na direção de trechos com áreas vagas, e a diminuição das rendas e dos valores do solo não seria igual em torno da circunferência inteira da cidade, mas mostraria variações de setor para setor, chegando mesmo a não haver diminuição no setor das rendas mais baixas (Eufrásio 2008: 130).

A setorização apresentada no modelo de Hoyt é o resultado da ênfase do autor no estudo das áreas residenciais, que o levou a notar o papel especial exercido pelas áreas residenciais de alto padrão, que atraíam para perto de si o avanço do centro da cidade e das residências de padrão intermediário, geralmente situadas no lado oposto da cidade àquele ocupado por indústrias e pelas maiores extensões de áreas residenciais de baixa renda (Hoyt 1939: 115-116). De acordo com esse autor, ocorria nas cidades norte-

${ }^{12} \mathrm{O}$ economista Homer Hoyt foi também um agente de investimentos imobiliários, e buscou, em sua carreira, unir a análise da estrutura urbana com o planejamento de investimentos imobiliários e com o planejamento urbano público. A capacidade de constatação de tendências de segregação urbana seria a chave para a aplicação das descobertas da investigação científica na prática do planejamento urbano (Eufrásio 2009: 25). 
americanas um processo de filtração, caracterizado como um processo da dinâmica de desenvolvimento urbano ${ }^{13}$. A filtração seria motivada pela desvalorização sucessiva de gerações de áreas residenciais, tornadas obsoletas pela produção de novas gerações de residências, de modo que as novas famílias de mais altas rendas ocupariam as novas residências disponíveis, e as casas antigas, quando mudavam de proprietários, passavam a ser ocupadas por famílias de rendas inferiores (Hoyt 1939: 131-132) ${ }^{14}$.

Para Hoyt, existe uma tendência de concentração das áreas residenciais de alto padrão em setores específicos da cidade, capazes de "arrastar consigo o crescimento da cidade inteira em sua direção" (Hoyt 1959: 499; apud Eufrásio 1999: 209). Para identificar essas áreas residenciais de alto padrão, o método apresentado por Hoyt visava qualificar as residências com base em dados médios por quarteirão. Dentre os dados disponíveis pelo autor, a ênfase maior foi dada aos dados acerca do valor financeiro das residências, considerados aqueles que mais refletem a média das informações totais do conjunto de dados de qualificação disponíveis. Assim, Hoyt utiliza como dado padrão para a elaboração dos seus mapas de representação da estrutura urbana a renda média de aluguel por quarteirão (Hoyt 1939: 142-144).

O resultado do desenvolvimento do modelo de representação da estrutura urbana de Hoyt foi denominado como uma teoria dos setores, pois as áreas residenciais de alto padrão permaneciam contíguas em seu crescimento para fora da cidade, em um padrão axial de segregação sócio-espacial, que se desenvolvia ao longo da história da cidade $^{15}$.

13 'É digno de nota o uso do termo 'filtração', por Hoyt, alternativamente a 'invasão' e 'sucessão', por exemplo, como conceitos da ecologia humana clássica que Burgess usara, para os processos de substituição dos residentes de uma área da cidade: na formulação de Hoyt, a filtração é o processo mais central da dinâmica do desenvolvimento urbano e não exige necessariamente, de modo algum, a pressuposição de processos ecológicos, quer se interpretado em termos de comportamentos de indivíduos e famílias, quer se interpretado como característica ou resultado do comportamento de grupos de determinados estratos ou classes sociais, na sociedade moderna" (Eufrásio 1999: 248-249).

${ }^{14}$ Mas havia a importante exceção das residências de mais alto padrão, que se tornavam "elefantes brancos" e passavam a ser ocupados por usos não-residenciais (idem).

15 "O núcleo dessas formulações está numa série de considerações, segundo as quais 'aparentemente, há uma tendência das vizinhanças dentro de uma cidade em mudar de acordo com o que pode ser chamado de a teoria dos setores da mudança das vizinhanças. A compreensão do esquema dentro do qual este princípio opera é facilitada em se considerando a cidade inteira como um círculo e as várias vizinhanças como se situando em setores que se irradiam a partir do centro desse círculo. Nenhuma cidade se conforma exatamente a este padrão ideal, naturalmente, mas essa forma geral é útil na medida em que, em nossas cidades americanas, os diferentes tipos de áreas residenciais tendem a crescer para fora ao longo de raios bastante distintos e o crescimento novo sobre o arco de um dado setor tende a assumir o caráter do crescimento inicial nesse setor' (...). Os setores assim delimitados expressariam claramente a dinâmica do desenvolvimento urbano: 'assim, se um setor de uma cidade se desenvolve primeiro como uma área residencial de baixas rendas, ele tenderá a reter esse caráter por longas distâncias na medida em que o setor se expande através do processo de crescimento da cidade. Por outro lado, se uma área de altas 


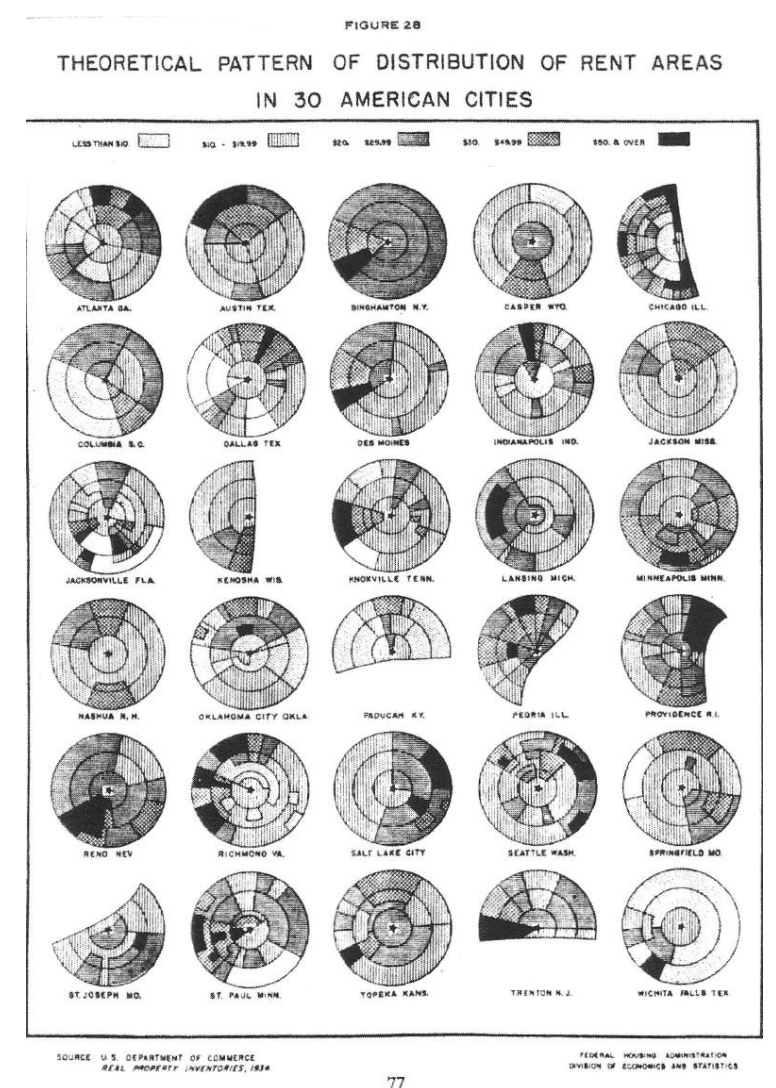

Figura 4. Modelo de setores de círculos de Homer Hoyt, com os setores de renda média por quarteirão indicando uma tendência para a concentração e o desenvolvimento histórico de áreas residenciais de alto padrão. Aqui se encontram cinco divisões de renda, com as cores mais escuras representando as áreas de rendas mais altas. Geralmente, no entanto, o autor se refere a três distinções básicas de renda: alta, intermediária e baixa. Fonte: Hoyt 1939.

\subsubsection{O modelo de Griffin e Preston}

Richard Preston é um geógrafo que desenvolveu sua carreira na Universidade de San Fernando Valley. Sua tese de doutorado, de 1964, foi um estudo comparativo acerca da zona de transição $^{16}$ de três cidades norte-americanas de porte médio: Richmond (Virginia), Worcester (Massachusetts) e Youngstown (Ohio). Em três artigos posteriores: "A zona de transição: um estudo dos padrões de uso do solo" (1966), "Uma Reformulação do Conceito de 'Zona de Transição"” (1966) ${ }^{17}$ e "Uma comparação detalhada do uso do solo em três zonas de transição" (1968), Preston e Griffin e Preston detalham sua metodologia, encaminhando os resultados da pesquisa empírica de Preston para a montagem de um esquema conceitual. Se Hoyt dá prioridade aos valores

rendas vem se estabelecer em outro setor da cidade, ela tenderá a crescer ou a se expandir dentro desse setor e novas áreas de alto padrão tenderão elas próprias a se estabelecerem na extensão externa do mesmo setor." (Hoyt 1959: 501; apud Eufrásio 1999: 210).

${ }^{16}$ Como foi denominada a segunda zona concêntrica do modelo de Burgess. Cf. figura 3.

${ }^{17}$ Nesse artigo, onde é apresentado o modelo dos núcleos de setor, Preston escreve em parceria com o também geógrafo Donald W. Griffin. Por isso o modelo foi considerado de autoria dupla. 
monetários dos imóveis como critério básico de classificação dos elementos urbanos, Preston e Griffin e Preston buscam principalmente identificar os tipos funcionais de usos do solo, tais como os usos industriais, residenciais e industriais, e classificá-los em relação à sua capacidade ocupar os terrenos mais valorizados do mercado imobiliário de uma cidade ${ }^{18}$.

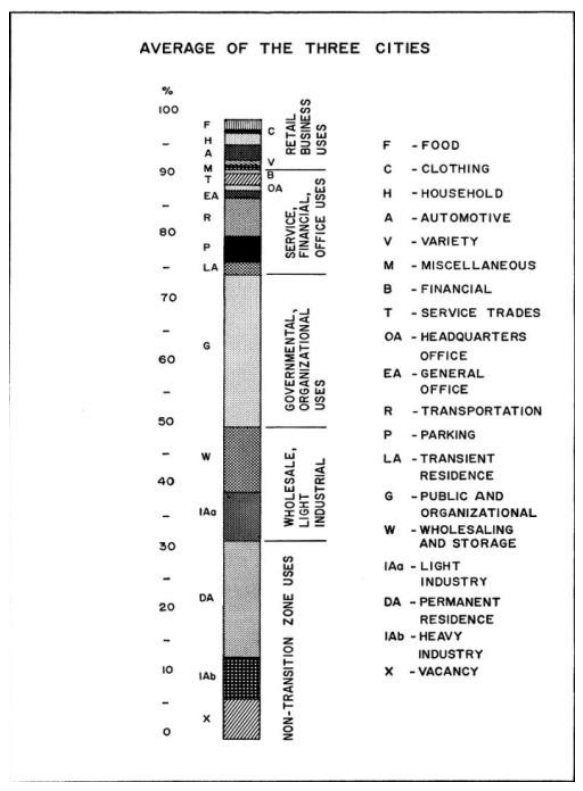

Figura 5. A classificação dos tipos de uso do solo de Murphy e Vance, conforme adaptada para o estudo da zona de transição por Richard Preston. Os usos do solo representados nas categorias superiores, varejo, serviços e escritórios são considerados os usos do solo típicos do CBD. Fonte: Preston 1966.

Como representação de sua análise comparada das zonas de transição das três cidades norte-americanas de porte médio, Griffin e Preston concebem o modelo de uma cidade dividida em quatro setores nos quais o processo de deslocamento da zona de transição - uma zona do modelo de círculos concêntricos de Burgess - pode se exercer de forma axial - como no modelo de Hoyt -, para então representar, dentro de cada setor, distintos núcleos de setor, definidos como "aglomerados de usos de solo" (Griffin e Preston 1966: 9-12). Essa última escala de análise permite a identificação de concentrações de usos e valores do solo inseridos dentro de um único setor, adjacente a outros núcleos internos ou vizinhos ao setor analisado.

\footnotetext{
${ }^{18}$ Convém destacar a influência exercida pelas pesquisas de Raymond Murphy e Murphy e Vance sobre a pesquisa de Preston e Griffin e Preston. Contando com o auxílio de outro geógrafo norte-americano, J. E. Vance, Raymond Murphy desenvolveu um método para a delimitação do "CBD", o distrito comercial central das cidades norte-americanas. O método é apresentado no livro The Central Business District, de 1972, fundamentado em pesquisas empíricas realizadas principalmente na década de 50 em cidades norteamericanas de porte médio. $\mathrm{O}$ método de pesquisa apresentado por Murphy e Vance, para delimitar o CBD, foi adaptado por Preston para a delimitação da zona de transição, adjacente e externa ao CBD (Cf. Preston 1966).
} 


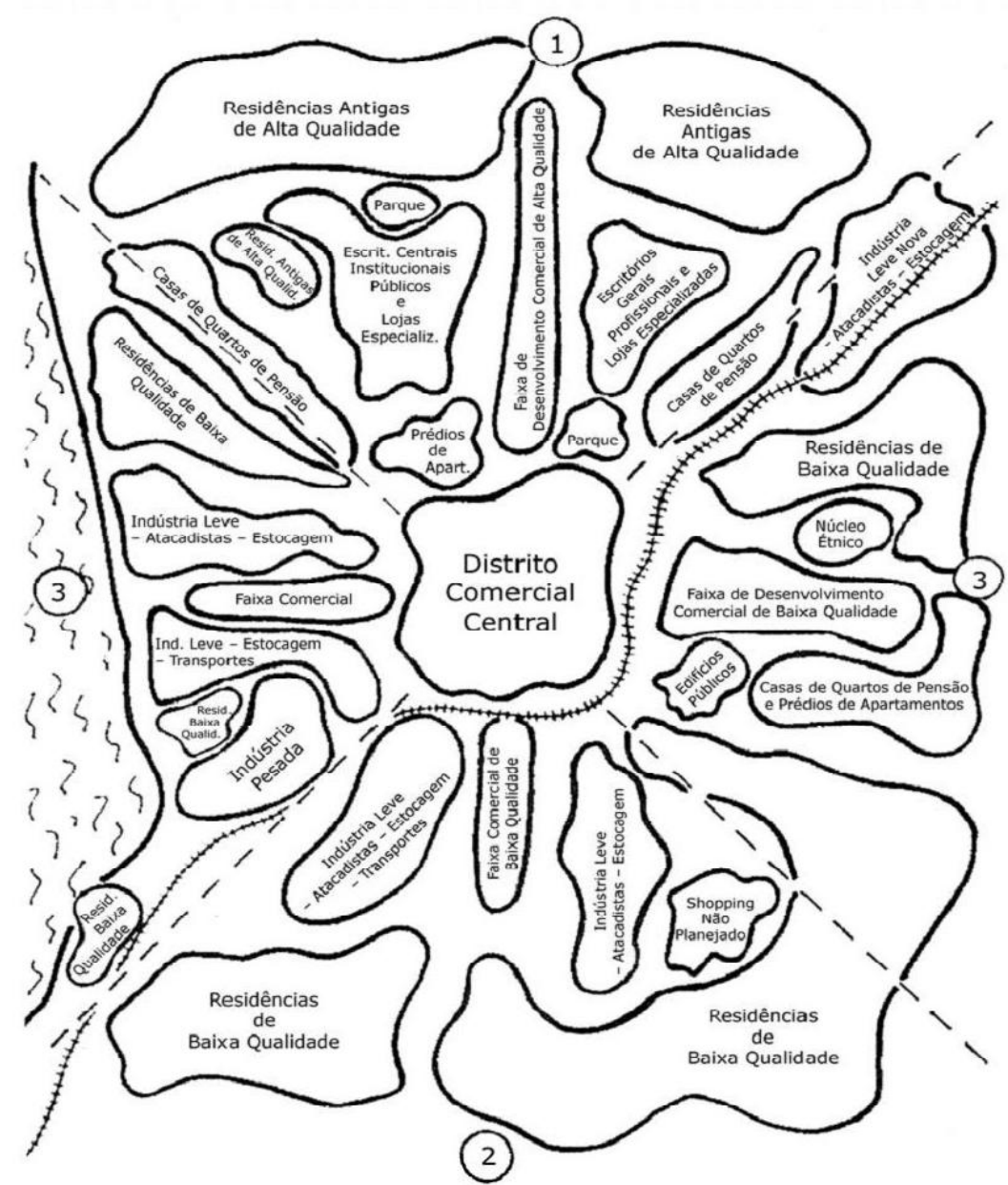

Figura 6. O modelo de núcleos de setor de Griffin e Preston. O conjunto de elementos que compõem a zona de transição forma um anel em torno do distrito comercial central (CBD), como no modelo de Burgess (figura 3). A zona de transição está dividida em quatro setores: (1) Setor de Assimilação Ativa; (2) Setor de Assimilação Passiva; (3) Setor(es) de Inatividade Geral. Como no modelo dos setores de círculo de Hoyt (figura 4), há um setor específico onde se concentram usos do solo residenciais e comerciais de alto padrão. Internos a esses quatro setores, há núcleos e faixas de associações de usos do solo. Fonte: Griffin e Preston 1966.

\subsubsection{Os três modelos como escalas de representação da estrutura urbana}

A partir da leitura desses três modelos de representação da estrutura urbana, é possível estabelecer três escalas básicas de delimitação e representação de elementos da estrutura urbana, aplicáveis ao caso da distribuição usos do solo em Goiânia: 1) enquanto concentrados no centro de uma cidade dotada de dois grandes círculos concêntricos; 2) enquanto concentrados em um eixo de desenvolvimento que se orienta para o sentido sul a partir do centro original da cidade; 3) enquanto concentrações geralmente inseridas dentro do círculo central e do eixo sul, onde coexistem com outros 
núcleos adjacentes, sejam eles comerciais, empresariais, de residências verticais, de residências de classe média, etc.

Apresentados os modelos que inspiraram essa pesquisa, posso agora definir uma noção de estrutura urbana. A estrutura urbana deve ser entendida nesta pesquisa como uma estrutura cujos elementos identificáveis ou unidades são: os agentes, tomados individualmente ou coletivamente enquanto grupos institucionalizados ou informais, e os objetos, sejam eles móveis, ou fixos no solo, os imóveis.

\subsection{O método descritivo e cartográfico}

A utilização de modelos de representação da estrutura urbana oferece um suporte gráfico para a realização do cruzamento de dados obtidos de diferentes fontes, na forma da apresentação de mapas. Um método descritivo da estrutura urbana consiste, conforme compreendido sob a perspectiva desta pesquisa, simplesmente no procedimento de mapear dados de tipo e qualidade, obtidos de diferentes fontes para diferentes períodos, referentes a quaisquer elementos identificados - as unidades da estrutura urbana - e dispostos sobre o espaço urbano.

Conforme adaptado para esta pesquisa, o método descritivo da estrutura urbana consiste no mesmo procedimento, porém focado principalmente no mapeamento de dados sobre imóveis dispostos sobre o espaço urbano. Os imóveis devem ser entendidos em um sentido ampliado, que não se restringe apenas a imóveis edificados ou inseridos no mercado imobiliário, mas que abrange quaisquer elementos identificáveis fixos no solo. Além disso, os imóveis podem ser associados e assim delimitados em conjunto. A representação dos modelos resultantes do procedimento resulta em mapas de períodos diferentes, o que permite a apreciação de padrões de configuração que se mantém ou se alteram ao longo do tempo ${ }^{19}$.

Como foi colocado acima, o procedimento de abordagem empírica do objeto aqui apresentado decorre do desenvolvimento de métodos de descrição e interpretação empírica da estrutura urbana que podem ser considerados métodos descritivos e cartográficos. Os métodos que podem ser denominados descritivos e cartográficos, como também já foi colocado, não se resumem à descrição de imóveis e de sua disposição. Quem utiliza um método similar pode representar nos seus mapas dados

19 As unidades são delimitadas em um momento específico. O mesmo tipo de delimitação pode ser realizado com a utilização de dados referentes a outro período histórico, de modo a obter um efeito de comparação que permita descrever permanências e mudanças estruturais. 
referentes a objetos móveis, tais como a densidade de fluxo de veículos. Dados sobre agentes também podem ser inclusos, como na representação cartográfica do trajeto social de um agente indicado por seus locais de moradia em As Regras da Arte; ou ainda como na representação cartográfica dos trajetos cotidianos de um agente, indicando, por exemplo, uma linha que conecta seu local de trabalho e seu local de moradia. No entanto, as dimensões dessa pesquisa restringiram o foco principal da representação cartográfica à descrição da posição, tipo e qualidade dos imóveis.

O método cartográfico adaptado para a descrição dos imóveis da estrutura urbana de Goiânia executou os seguintes passos de pesquisa: (a) identificação de imóveis, (b) qualificação dos imóveis, (c) categorização descritiva dos imóveis, (d) periodização, (e) escalonamento e (f) identificação de práticas de sociabilidade associadas aos imóveis de alto padrão, como se segue:

a) Identificação: a identificação dos imóveis foi feita de diversas formas e a partir de diversas fontes, mas a referência básica para essa identificação é a diferenciação tipológica ou funcional; ou seja, a distinção entre os usos do solo urbano. Assim, a identificação, a nível básico, é equivalente à produção de uma tipologia dos usos do solo urbano, inclusa na categorização dos imóveis urbanos considerados relevantes para esta pesquisa.

Os tipos de usos do solo descritos são quatro: residencial, comercial, público e misto. O uso residencial não inclui hotéis, e, por conveniência de pesquisa, não inclui também os flats. Incluí como "comerciais" todas as atividades de comércio, escritórios particulares e prestação de serviços, além de atividades comerciais destinadas à diversão e ao lazer, tais como cinemas, bares, lanchonetes, hotéis, galerias e shopping-centers. Como "públicas", foram consideradas todas as edificações classificadas como "públicas" ou "institucionais-filantrópicas" pela tipologia dos usos do solo apresentada por Preston (1966: 239-240). Assim, igrejas, escolas, colégios, universidades, lojas maçônicas, instituições e fundações não comerciais diversas, edifícios administrativos e de serviços públicos, centros culturais, museus e monumentos se encaixam nessa categoria, além do sistema viário, de parques, praças e quaisquer áreas de livre circulação permitida ou de propriedade estatal. O uso misto é aquele que reúne mais de uma das categorias anteriores. Muitas vezes, foram reunidos todos os usos além do residencial na categoria "não residencial". 
Mas foi necessário ainda um desenvolvimento da identificação dos elementos urbanos, para além de uma tipologia básica dos usos do solo, de modo a permitir a descrição de dois processos, o processo de ocupação de uma área loteada e o processo de verticalização.

Assim, foram considerados verticais os edifícios com mais de dois andares. Nesse sentido acompanhei a bibliografia que se refere aos momentos iniciais da cidade de Goiânia, que caracteriza a paisagem horizontal das primeiras décadas da cidade ${ }^{20}$. Dois dos edifícios mais conhecidos da cidade e construídos na década de 30, o Palácio das Esmeraldas e o Grande Hotel, possuem três andares, e como se observa em fotografias antigas, esses edifícios se destacavam na paisagem da cidade nas décadas de 30 e 40. Também foram levados em consideração os primeiros indícios de ocupação residencial na forma de edifícios residenciais de habitação coletiva, que tinham a altura padrão de três andares e também podem ser observados em fotografias antigas. Por isso, foram considerados "altos", aqueles edifícios verticais mais recentes que possuem mais de três andares, e geralmente possuem elevadores.

b) Qualificação: a qualificação dos imóveis tem como objetivo principal descrever aqueles elementos que podem ser considerados de alto padrão. O trabalho de qualificação dos imóveis responde às motivações básicas da pesquisa, ligadas à busca de encontrar uma explicação sociológica para os processos que modificam a estrutura urbana, conforme extraí de Mário Eufrásio, estimulada pela leitura de Flavio Villaça e da referida série de autores norte-americanos, também dedicados a uma análise estrutural da cidade.

O exercício de qualificação de elementos urbanos foi fundamental para as teses decorrentes das pesquisas de Hoyt e de Villaça, pois ambos os trabalhos indicam uma tendência que não é muito diferente daquela que Simmel observou no circuito da moda, ao tratar de outros objetos: Os imóveis de alto padrão tendem a ser segregados, isto é, tendem a se aproximar mutuamente e a se distanciar de outros imóveis. Por outro lado, os imóveis de alto padrão "atraem” os imóveis de padrão médio na medida em que estes seguem os passos daqueles.

Como exemplo, uma forma de qualificação de edificações de padrão médio e médio-alto se deveu ao fato de que, em Goiânia, foi descrito um fenômeno típico das

\footnotetext{
${ }^{20}$ Cf. Gonçalves 2002, Daher 2003 e Medeiros 2007.
} 
edificações de padrão médio, que foi denominado "fachadismo",21. O "fachadismo" é a apresentação de edificações construídas com fachadas que emulam os estilos arquitetônicos que "estão na moda". Assim, os edifícios comerciais da cidade-satélite de Campinas, construídos entre as décadas de 30 e 50, são construídos no "estilo tradicional", com os "velhos" telhados de quatro águas. Porém suas fachadas ostentam o mesmo estilo art déco vigente nas casas comerciais mais prestigiosas, situadas no centro de Goiânia, e nos edifícios públicos monumentais (Gonçalves 2002: 96). A rua 20 e a rua 24 apresentam, no mesmo período, uma relação parecida entre os imóveis de padrão alto e os imóveis de padrão médio. Na rua 20, a primeira faixa residencial de alto padrão da cidade, foram construídos na década de 40 alguns sobrados em estilos arquitetônicos da moda, como o estilo normando e o neocolonial ${ }^{22}$. Na vizinha rua 24 , que corre paralela à rua 20, Badan (2007) encontrou um mobiliário similar ao da rua 20, mas utilizado em residências que eram construídas nos padrões ordenados pelo primeiro plano diretor para a construções térreas de padrão médio, as chamadas "casas-tipo" de "funcionários". De acordo com Badan, a parte externa dessas residências recebeu fachadas que emulavam os estilos dos sobrados da rua 20 (2007: 131). Esse mesmo fenômeno se manifestou em décadas posteriores, com o surgimento das "casas modernas", que ainda hoje exibem suas arrojadas formas retangulares nas ruas de Goiânia, ainda que cercadas de altos edifícios, marcando locais da cidade onde foram construídas residências horizontais do mais alto padrão nas décadas de 50,60 e $70^{23}$. Muitas casas de padrão médio, construídas no mesmo período, lembram singelamente o modernismo arquitetônico ao mostrar fachadas que representam as colunas do Palácio da Alvorada, em Brasília (Silva Neto 2010: 20).

Para efetuar a qualificação dos elementos urbanos da cidade de Goiânia em suas diferentes escalas, me inspirei em Hoyt (1939), que se refere geralmente a três níveis de padrão de áreas residenciais, o padrão alto, o médio e o baixo. Por vezes, no entanto, identifiquei elementos urbanos de padrão médio-alto, geralmente residências ou conjuntos de residências situadas internas ou próximas a elementos de alto padrão. Menos frequentemente, identifiquei elementos urbanos de padrão médio-baixo, quando as fontes consultadas permitiram tal qualificação.

\footnotetext{
${ }^{21}$ Utiliza-se aqui a mesma denominação aplicada por Gonçalves (2002), que descreveu o fenômeno na antiga cidade-satélite de Campinas, atualmente apenas um bairro de Goiânia.

${ }_{22}$ Oliveira e Silva (2006) identificou esses sobrados de alto padrão e seus estilos arquitetônicos.

${ }^{23}$ Cf. Silva Neto 2010.
} 
A qualificação é efetuada com a utilização de diferentes fontes, muitas vezes cruzadas. Como exemplo, a observação fotográfica combinada com fontes de jornais do período das décadas de 80 e 90, a localização, a identificação do estilo arquitetônico e datação de edificações, além de caminhadas com registro fotográfico de campo, tornaram possível a delimitação áreas residenciais horizontais de alto padrão características da época referida, situadas em três bairros adjacentes, os Setores Oeste, Marista e Bueno.

c) Categorias descritivas da abordagem da estrutura urbana utilizada, ou as categorias cartográficas: as categorias cartográficas aqui descritas não são derivadas apenas das referências teóricas da pesquisa, mas foram moldadas pelas atividades empíricas de investigação e categorização da estrutura urbana até agora efetuadas por essa pesquisa. Por isso, elas são específicas para o estudo dos imóveis de alto padrão. Sua característica básica é a de que elas representam os imóveis urbanos ${ }^{24}$.

Como observação, adianto que o procedimento se aplicará apenas aos imóveis considerados mais relevantes para a pesquisa, que são os seguintes:

I: Imóveis não urbanizados inseridos no contexto urbano

I.a.) Vazios urbanos: foi considerado um vazio urbano qualquer área não ocupada por edificações que possua ao menos dois de seus flancos adjacentes a áreas já ocupadas pela cidade ${ }^{25}$. Os vazios urbanos podem ser compostos por áreas não urbanizadas, mas podem também ser observados em Goiânia sob a forma de loteamentos já arruados, mas praticamente desprovidos de ocupação ${ }^{26}$. Essa caracterização arbitrária se fez necessária empiricamente por que encontrei grandes vazios urbanos nas fotografias aéreas disponíveis na SEPLAM, e também várias referências aos "vazios urbanos" na bibliografia pesquisada, mas sem maiores especificações sobre o que seriam tais vazios urbanos ${ }^{27}$. Essa caracterização aplicada à

\footnotetext{
${ }^{24} \mathrm{Ou}$ áreas não urbanizadas adjacentes à estrutura urbana propriamente dita, no caso de exceção das áreas rurais adjacentes (I.b, abaixo).

${ }^{25}$ Algumas classificações encontradas não fazem a distinção entre grandes vazios urbanos e qualquer tipo e os lotes desocupados. Os vazios urbanos podem ser identificados ainda pela transição do estatuto legal da terra, ao se inserirem nos "perímetros urbanos" ou "zonas de expansão urbana". Mas esse método exige o recurso e fontes específicas e exclui a possibilidade de identificar os vazios urbanos a partir de fotografias aéreas.

${ }^{26}$ Nesse caso de vazios urbanos já arruados e não ocupados, trata-se de área já urbanizada, portanto não irá se aplicar o critério dos dois flancos urbanizados como forma de classificação de uma área como um vazio urbano. Assim, qualquer área já arruada, mas não ocupada, é considerada um vazio urbano.

${ }^{27}$ Parece não haver um consenso sobre o termo, que pode designar quaisquer terrenos não-construídos na cidade em alguns casos, ou as grandes reservas de terra que encontrei nas fotografias em outros casos.
} 
análise de fotografias aéreas revelou o fato importante de que, em toda a história da cidade, os maiores vazios urbanos sempre se concentraram na parte sul de Goiânia, em terras originalmente pertencentes a três únicos proprietários: o Estado (sul-sudoeste), os irmãos Coimbra Bueno (sudoeste) e Lourival Louza (sudeste) ${ }^{28}$.

I.b) Áreas rurais adjacentes: essas áreas se diferenciam dos vazios urbanos por possuírem apenas um de seus flancos limitados por áreas já urbanizadas. Na medida em que a cidade cresce, áreas rurais adjacentes podem se converter em vazios urbanos, com a ocupação de seus flancos. Esse movimento pode ser mapeado ainda pela análise da expansão das zonas suburbanas e posteriormente das zonas de expansão urbana nos sucessivos mapas de zoneamento da cidade.

II: imóveis não loteados

II.a) Rios, córregos e alagadiços: esses imóveis muitas vezes servem como limites, e mesmo rios podem ser "urbanizados", quer seja pela sua canalização, quer seja por obras urbanísticas ao longo de suas margens. Tradicionalmente, como observa Villaça em outras cidades brasileiras, as áreas marginais a cursos d'água de Goiânia foram ocupadas por habitações do mais baixo padrão (2001: 228). Outra presença típica às margens de cursos d'água são as estradas de ferro, que, de acordo com Villaça, operam como linhas divisórias entre diferentes áreas da cidade. O "lado de lá" de um rio, para Villaça, é a parte de uma cidade, dividida por um rio ou pela associação de um rio e uma estrada de ferro, onde não está situado o centro. (idem: 116).

II.b) Estrada de ferro: como mencionado acima, de acordo com Villaça, as estradas de ferro se dispõem tradicionalmente no Brasil ao longo de rios (ibid:: 114116). Em Goiânia esse foi o caso, concebido de acordo com o planejamento inicial da cidade. Além disso, as estradas de ferro são citadas pelos autores pesquisados, como Villaça, entre outros, como "barreiras" que repelem os imóveis de alto padrão (ibid.). Em Goiânia as estradas de ferro seguiam esse padrão quando se estendiam às partes centrais da cidade, e seus remanescentes ainda podem ser observados em imagens de satélite.

II.c) Vias públicas, cruzamentos e rodovias: as vias públicas são imóveis que, conforme observamos na cidade de Goiânia, podem atuar como imóveis estruturadores de três formas observadas. Uma delas está relacionada diretamente com as atribuições legais, determinadas pelas legislações e pelos planos diretores da cidade, que indicam

\footnotetext{
${ }^{28}$ Cf. Gonçalves 2002, Daher 2003.
} 
certas vias como áreas dedicadas a um ou mais usos do solo específicos. Outra forma de atuação está na geração de um gradiente de qualidade imobiliária, como pode ser observado in situ, pela concentração de edifícios de alto padrão em torno dos parques urbanos localizados nos "bairros nobres" da cidade. O asfaltamento de uma rua, por exemplo, poderá atribuir mais valor às edificações nela dispostas, enquanto a construção de um elevado ou de um túnel poderá gerar um contexto depreciativo de atribuição de qualidade a suas imediações. Uma terceira forma de atuação na estruturação é a de servir como limite formal ou informal entre duas vizinhanças ou dois bairros distintos. Nos dois primeiros casos, podem surgir aglomerações identificáveis por tipo ou qualidade dos usos dos solos dispostos ao longo de vias, o que irei caracterizar como faixas. É possível ainda a realização de uma tipologia mais apurada das vias e do sistema de transporte que elas estruturam, mas infelizmente tal projeto excede as dimensões desta pesquisa.

II.d) Praças: as praças atuam como imóveis estruturadores de modo similar às duas primeiras formas de atuação das vias, acima descritas. Desse modo, as praças podem gerar aglomerações de imóveis orientadas pelo planejamento urbano e determinadas pela lei, ou gradientes de valor imobiliário com um incremento da qualidade dos usos em seu redor. Nesses dois casos, há a formação de núcleos. Uma praça pode ter uma mudança detectável em seu contexto de qualificação induzida por obras de urbanização, pela mudança da lei de zoneamento ao seu redor ou por modificações em seu uso público, como por exemplo, a remoção de mendigos e usuários de drogas de seu interior, que pode "reativar" um aumento do valor imobiliário atribuído ao seu entorno.

II.e) Parques: os parques, conforme observados em Goiânia, atuam de maneira similar às praças, podendo gerar núcleos em seu entorno, geralmente na forma de gradientes de valor em áreas residenciais em seu entorno.

III: Imóveis delimitados por lotes

III.a) Lotes vagos: os lotes vagos podem estar situados em loteamentos já implantados ou arruados, ou em loteamentos ainda não implantados. Quando o tamanho do lotes é padronizado, loteamentos diferentes oferecem lotes com tamanhos diferentes, 
de modo detectável na análise empírica da estrutura urbana, revelando um de seus critérios de qualificação ${ }^{29}$.

III.b) Residências horizontais unitárias: são as edificações residenciais unitárias ou principais $^{30}$, que também podem ser chamadas de casa, sobrado (casa de dois pavimentos) ou simplesmente de residência.

III.c) Residências verticais: foram considerados os edifícios residenciais de dois e três andares como edifícios verticais baixos, e os edifícios residenciais com mais de três andares como edifícios verticais altos.

III.d) Edificações comerciais horizontais: essas edificações podem ser próprias, construídas para fins comerciais, ou podem ser antigas residências convertidas para o uso comercial. Elas podem ocorrer em edifícios coletivos - galerias - ou podem ocupar construções isoladas. São consideradas horizontais as edificações comerciais de um ou dois andares.

III.e) Edificações comerciais verticais: também são consideradas altas ou baixas, conforme o item "c" acima.

III.f) Edificações de uso misto horizontais: são aquelas que possuem dupla função, residencial e comercial, e podem ser edificações de um ou dois andares.

III.g) Edificações de uso misto verticais: também consideradas "altas" ou "baixas" conforme especificado acima. Geralmente são encontrados em Goiânia edifícios verticais altos de uso misto, caracterizados por lojas no térreo e por residências nos andares superiores, como ocorre em outras cidades brasileiras. Modelos mais recentes de edifícios mistos de alto padrão estão sendo construídos de acordo com novos padrões arquitetônicos.

III.h) Edificações de uso público: alguns desses imóveis urbanos públicos podem estruturar núcleos, ou aglomerações identificáveis em seu redor, como no caso da Praça Cívica, que recebeu em seu entorno imóveis residenciais de alto padrão a partir da década de 30, como mostra Oliveira e Silva (2006) e como pode ser observado em fotografias.

IV: As unidades de imóveis associados, ou as associações de imóveis

\footnotetext{
${ }^{29}$ Um imóvel pode ocupar mais de um lote, como no caso de um indivíduo que constrói sua casa em dois terrenos, ou de um edifício construído sobre um conjunto de terrenos antes pertencentes a diferentes proprietários e ocupados por edificações horizontais.

${ }^{30}$ O termo "principais" se refere à possibilidade de ocorrência de uma habitação associada, tal como uma edícula ou um quarto de aluguel. De qualquer modo, usos desse tipo, bem como residências coletivas horizontais não são levados em consideração por não terem sido empiricamente significativos em uma pesquisa dos imóveis urbanos de alto padrão.
} 
IV.a) Os núcleos: os núcleos são concentrações de imóveis específicos, distintos por função ou qualidade, associadas a uma edificação, uma praça ou a um parque. Assim como no caso das faixas, os núcleos foram descritos por Griffin e Preston, que os denominaram "núcleos de setor" (1966: 9-10). O núcleo pode ser empiricamente detectável como composto por tipos distintos de uso do solo, o que indica um núcleo funcional, ou pode ser identificável como um gradiente de valor, o que indica um núcleo de gradiente. Os núcleos de alto padrão só são detectáveis no caso de haver uma aglomeração perceptível, de modo a apresentar um conjunto de edificações de alto padrão significativo, tanto em termos de identificação visual, quanto por terem sido identificadas pela história, pela geografia, pela literatura, pela iconografia, pela imprensa e pelos habitantes de um modo geral. Os núcleos apresentam uma disposição que não é necessariamente idêntica ao planejamento inicial dos imóveis estruturadores que o geraram. Assim, pode-se dizer que os critérios de qualificação que levam ao aumento do valor do solo da área podem não estar presentes em estágios iniciais da implantação do imóvel estruturador. Ou ainda, mesmo estando presentes, os critérios de qualificação podem operar de forma diferente, conforme o período e o estágio da implantação do projeto. Isso leva a crer que o imóvel estruturador, ou seja, o objeto fixo que atrai uma aglomeração de outros objetos, responde a um contexto histórico específico, e por isso tem um período específico de "funcionamento", que pode inclusive se inverter e reverter novamente. Como ocorre no já referido exemplo de uma praça, antes considerada aprazível e capaz de valorizar seu entorno, que é desvalorizada ao ser utilizada por usuários de drogas e mendigos por certo período de tempo, até ser finalmente "revitalizada" e revalorizada.

IV.b) As Faixas: as faixas são concentrações de usos do solo específicos, distintos por função ou valor, associadas a uma via, que atua como o imóvel estruturador de uma faixa funcional ou de gradiente. Assim como no caso dos núcleos, as faixas podem ser detectáveis empiricamente através da análise da estrutura urbana.

IV.c) As áreas residenciais: as áreas residenciais são assim nomeadas quando a análise da estrutura urbana encontra uma disposição de residências sem nucleação aparente. Existem dois casos típicos de áreas residenciais observadas em Goiânia. O primeiro caso se refere a áreas residenciais de padrão inferior, detectadas na periferia de um gradiente de valores formado como faixa ou núcleo, ou ainda situada entre faixas e núcleos de funções não residenciais, as faixas e núcleos funcionais. O segundo caso é o do processo de formação de uma área urbana, que ocorre em um período que se estende 
do início da ocupação de um loteamento até o momento em que se tornam visíveis suas nucleações, com a formação de faixas e núcleos funcionais ou de gradiente $^{31}$. Respectivamente, os dois casos são nomeados como áreas residenciais (a) associadas ou adensadas; ou (b) em formação ou loteamentos ${ }^{32}$. Se a área residencial em questão estiver em um local onde a lei municipal de zoneamento permite a construção de edifícios verticais, ou se uma mudança nessa lei passar a permitir a construção de edificações desse tipo, então, em todas as áreas residenciais de alto padrão observadas ocorre um processo de verticalização. Em Goiânia, a verticalização das áreas residenciais de alto padrão ocorre desde o início de sua ocupação, a não ser quando não é permitida a construção desse tipo de edificação ${ }^{33}$. Por outro lado, a demolição de edificações mais baixas para a construção de edificações verticais poderá ocorrer tanto por ocasião da mudança das leis de zoneamento de uma área residencial, quanto através da demolição de edificações "velhas" para a construção de edificações novas ${ }^{34}$. São desconhecidos para esta pesquisa casos de demolição de edificações verticais altas em Goiânia.

$\mathrm{V}$ : as associações de imóveis de segundo grau ou os distritos

Os distritos são formados por conjuntos associados de faixas, núcleos e áreas residenciais. Os distritos de imóveis de alto padrão podem incluir também áreas residenciais de padrão inferior ao alto padrão; ou seja, de padrão médio ou médio-alto.

VI: As associações de imóveis de terceiro grau ou os setores

Trata-se de um conjunto de distritos de imóveis associados, que, distintos qualitativamente, apresentam um formato axial decorrente da expansão histórica dos

\footnotetext{
${ }^{31} \mathrm{O}$ primeiro caso pode ser observado in situ na orla de parques urbanos ou em torno de algumas praças, como a Praça Alternativa, no Setor Bueno. O segundo caso pode ser observado na análise de fotografias aéreas.

${ }^{32}$ Quanto aos loteamentos observados por fotografias aéreas, foram delimitadas cinco fases de sua ocupação: a fase de loteamento não implantado ou não arruado, a fase de loteamento implantado e desocupado, a fase de loteamento com baixa densidade de ocupação, a fase de loteamento com média densidade de ocupação e a fase de loteamento adensado. Esse mesmo critério pode também medir o adensamento de edifícios verticais em uma área urbana, ocupada ou não por edificações horizontais. Esse processo pode ser aplicado a qualquer área loteada, na verdade, não apenas às áreas residenciais.

${ }^{33}$ Essa foi uma interessante constatação que pôde ser observada desde os primórdios da ocupação das áreas melhor localizadas de Goiânia. No Setor Oeste, por exemplo, podem ser encontrados edifícios verticais baixos, residenciais ou de uso misto, ao lado das primeiras residências de padrão médio e alto que ocuparam a área, quando grande parte dos terrenos ainda estava desocupada. Isso quer dizer que não há em Goiânia uma relação automática entre o adensamento e a verticalização. Vários outros exemplos, antigos e recentes de produção de imóveis verticais em áreas desocupadas podem ser encontrados em Goiânia, embora essa disposição não altere a acentuada tendência de verticalização encontrada em bairros anteriormente ocupados por residências horizontais de alto padrão.

${ }^{34}$ Recentes demolições de antigas residências de alto padrão indicam que o valor patrimonial ou arquitetônico desses imóveis ainda não é suficientemente reconhecido para inviabilizar a tendência à verticalização.
} 
imóveis de alto padrão. Esse conjunto de distritos de alto padrão forma o setor de imóveis de alto padrão. É preciso destacar aqui que a única forma encontrada de descrever um setor é pela sua qualificação em padrões hierárquicos, pois uma classificação apenas funcional não poderia detectá-lo. Em Goiânia, é possível detectar, como no modelo original de Hoyt e como na aplicação desse modelo nas metrópoles brasileiras por Villaça, uma sucessão axial e centrífuga de distritos de imóveis associados de alto padrão. Tal observação confirma uma tendência de avanço histórico das áreas residenciais de alto padrão que, de acordo com Villaça (2001), Hoyt (1939) e Griffin e Preston (1966), orienta o sentido do deslocamento das funções típicas das centralidades de alto padrão ${ }^{35}$. Em Goiânia, uma sucessão de áreas residenciais de alto padrão foi seguida, ocupada ou cercada por imóveis não residenciais ou verticais de alto e médio padrão, bem como por residências de padrão médio. Essa é uma tendência que só pôde ser contrabalanceada de modo limitado e esporádico pela decisão política e pelo planejamento urbano governamental, nos momentos em que este não atua em favor do processo $^{36}$. Assim, os setores de renda fazem ver como há um vetor residencial de maior atribuição de valor, que se desloca para fora da cidade em direção à periferia. Mas, para notar essa configuração, é preciso distinguir as áreas de mais alto padrão das áreas de padrão mediano, que se situam adjacentes a áreas de alto padrão. Em Goiânia, a etapa inicial desse estudo fica grandemente facilitada por essa estratificação sócio-espacial ter sido determinada pelo próprio plano diretor inicial da cidade, uma estratificação nítida que divide e separa espacialmente a cidade planejada em três categorias sociais ${ }^{37}$. O tipo de segregação sócio-espacial proposto no pelos criadores de Goiânia não é muito diferente daquele representado por Hoyt, embora as classes sociais representadas por imóveis no plano piloto de Goiânia sejam designadas pela função econômica dos seus integrantes, enquanto os estratos de Hoyt são determinados pelo valor investido na moradia $^{38}$.

\footnotetext{
${ }^{35}$ Isto é, os imóveis não-comerciais e os imóveis verticais de alto padrão.

${ }^{36}$ Muitas vezes a atuação pública é ambígua e, de acordo com um consenso generalizado nas fontes acadêmicas pesquisadas, é particularmente sensível aos interesses do mercado imobiliário.

${ }^{37}$ Deixando para aqueles que não se enquadram em nenhuma dessas três categorias a tarefa de produzir e ocupar os bairros marginais.

${ }^{38}$ As categorias sociais associadas às primeiras residências regulares de Goiânia podem ser encontradas na documentação produzida entre 1933 e 1938 pelos planejadores e construtores da nova capital de Goiás. Essas categorias nomeavam a tipologia residencial: as casas menores e mais afastadas do Centro Administrativo foram denominadas "casas-tipo de operários"; aquelas qualitativamente intermediárias e do mesmo modo distribuídas no espaço urbano (entre as moradias dos operários e as moradias da elite) foram denominadas "casas-tipo de funcionários"; e aquelas destinadas aos moradores notáveis, foram denominadas "casas-tipo especiais". Essas últimas tiveram projetos personalizados e tinham o nome de
} 
VII: As associações de imóveis de quarto grau ou as zonas concêntricas

Em sua apresentação inicial por Burgess, o círculo dividido em anéis que representava a cidade de Chicago era dominado pela concepção de uma relação entre os valores e os usos do solo, na qual os usos ou conjuntos associados de usos do solo se apresentavam arranjados em um gradiente que inclui como um de seus aspectos fundamentais a hierarquia centrípeta dos valores do solo. O mais alto valor do solo urbano está na zona mais interna da cidade, o Loop, e a expansão do Loop responde pelo movimento mais poderoso que se sobrepõe às zonas urbanas mais periféricas ${ }^{39}$.

No Brasil, como notou Villaça, a divisão sócio-espacial mais geral da cidade envolve duas grandes zonas concêntricas (Villaça 2001: 113). O antigo modelo norteamericano não foi aplicado na íntegra a Goiânia, mas é viável uma utilização geral do modelo, conforme uma técnica básica de mapear a cidade em relação ao valor e ao tipo do uso do solo. Um mapa simples pode então dividir a cidade de Goiânia em dois grandes círculos concêntricos, que correspondem ainda a categorias utilizadas no cotidiano para classificar áreas urbanas: centro e periferia. As fotos aéreas disponibilizadas pela SEPLAM podem ainda fornecer os meios de análise para a periodização do modelo, pelo cruzamento da análise das fotografias com dados econômicos e fotografias de edificações. Concebe-se assim a cidade, entendida como a área contígua urbanizada visível em fotos aéreas ou de satélite, como distinta em dois círculos concêntricos que representam padrões de valor e/ou densidade. Aos dois círculos obtidos podem corresponder regiões culturais conhecidas pela população e tradicionalmente distintas, o centro e a periferia.

Se a periodização do modelo de representação dos círculos concêntricos indicar um processo de crescimento do círculo interno, que corresponde às áreas de mais alto valor do solo, em conjunto com a disposição dos bairros considerados pela imprensa local como "de classe média", e ainda com as áreas de verticalização de padrão alto e médio - que podem ser morfologicamente distintas de áreas de verticalização

seus moradores referidos nos relatórios dos construtores enviados aos órgãos administrativos de estado. A tipologia encontrada nos relatórios enviados à administração pública por Attilio Corrêa Lima e posteriormente pelos técnicos da construtora Coimbra Bueno é "completa", no sentido desejado como o ideal de uma fonte para esta pesquisa, pois inclui registro fotográfico, localização, número de cômodos, orçamento de construção e descrição do material utilizado. Tudo segue na mais perfeita ordem, de acordo com a hierarquização e a correspondência de todos os critérios de qualificação nomeados, pois as casas "especiais" são as de construção mais cara, com materiais especiais, maior número de cômodos, maior área construída, e "melhor localização" em relação à Praça Cívica. A ordem hierárquica sucede com total concordância dos elementos (Cf. Alvares 1942).

${ }^{39}$ Cf. Nota 10 acima. 
“excêntricas" - ${ }^{40}$, então a área do círculo interno pode ser denominada centro ampliado de Goiânia $^{41}$. É possível identificar o centro ampliado em sua forma recente tomando um simples mapa cultural ou turístico da cidade, pois tais mapas costumam indicar uma concentração dos pontos destacados na parte central da cidade e ainda indicar o lado para o qual o centro mais cresceu. No mapa abaixo, o centro original da cidade está deslocado para o norte, o que indica um maior crescimento do centro no sentido sul.

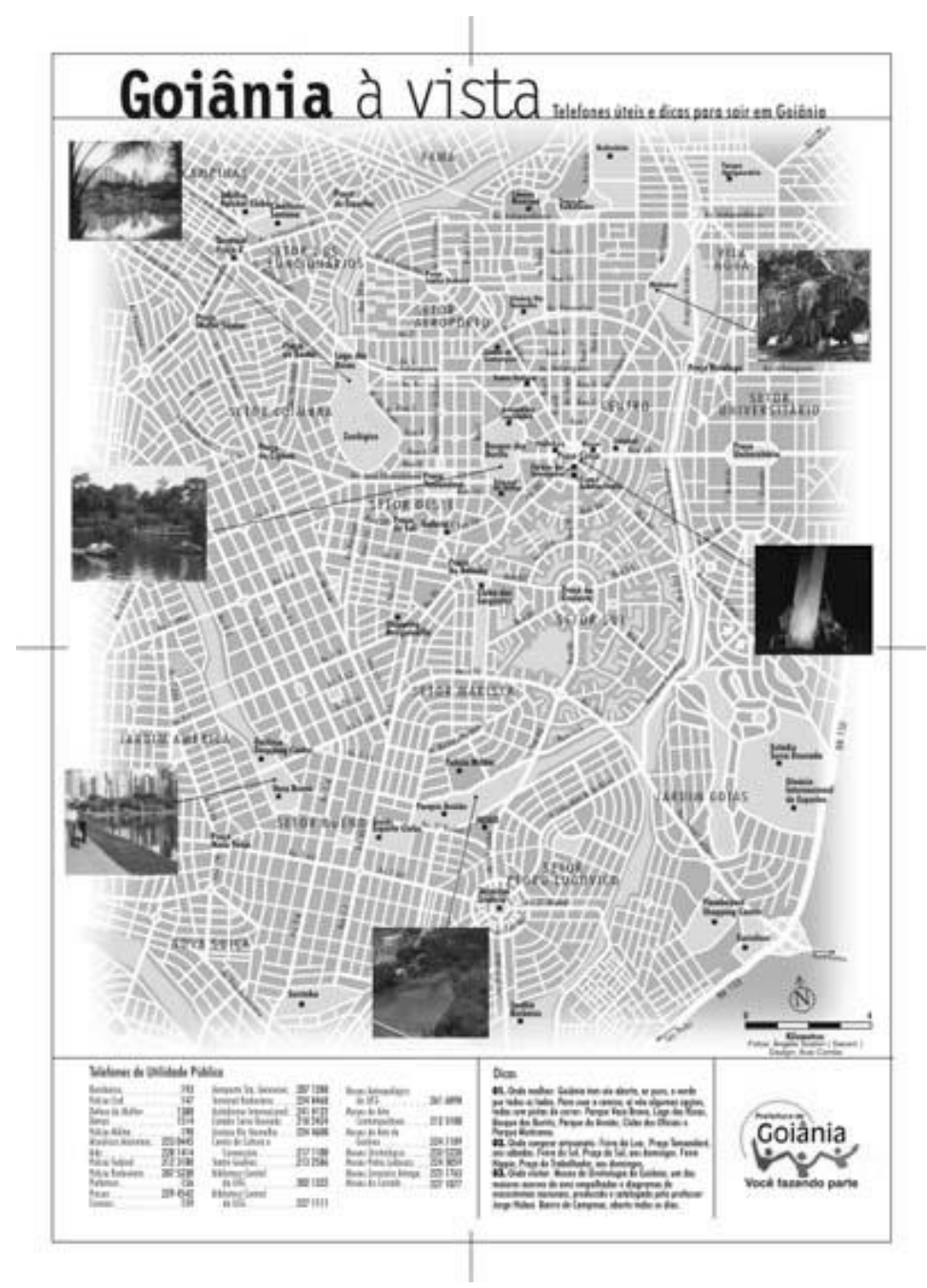

Figura 7. Exemplo de mapa do tipo "centro expandido" da cidade de Goiânia, produzido pela Secretaria Municipal de Turismo, que indica pontos de interesse turístico-cultural na cidade. Fonte: SEPLAM

d) Periodização: a periodização foi necessária para possibilitar a comparação dos imóveis por fases. Conforme a pesquisa se desenvolveu, foi notado que os estilos arquitetônicos, os padrões de urbanismo e a tipologia interna das edificações - a

${ }^{40}$ Como exemplo de verticalização excêntrica ou periférica, posso citar os típicos conjuntos residenciais verticais de padrão médio-baixo construídos por iniciativa de projetos públicos de habitação nas décadas de 60 e 70.

${ }^{41}$ O que se aproxima de uma categoria utilizada no planejamento urbano, o "centro expandido". 
disposição e a função de seus cômodos, por exemplo -, apresentam transformações ao longo do tempo. Diferentes "gerações" de imóveis urbanos podem ser descritas pelo uso de fontes primárias e secundárias ou pela observação de suas características morfológicas. Com isso, abre-se a possibilidade de uma delimitação empírica de estilos arquitetônicos e o conseqüente estabelecimento de fases históricas.

No tocante às residências horizontais de alto padrão, cinco "gerações" de estilos arquitetônicos foram detectadas durante a pesquisa: a "geração 0", composta pelas residências construídas sob contrato pelo próprio Estado, quando da fundação da cidade na década de 30. Dessas, as residências de mais alto padrão eram as assim chamas "casas-tipo especiais". Logo a seguir, vieram os estilos arquitetônicos utilizados nas primeiras residências de alto padrão construídas a mando de particulares, entre as décadas de 30 a 50, nos estilos art-déco $^{42}$, normando, neocolonial e eclético. A próxima "geração" de residências horizontais de alto padrão, cujos exemplos se situam entre as décadas de 50 e 70, foi construída de acordo com o estilo moderno. Entre as décadas de 70 e 90, forma-se uma nova "geração", que pode ser denominada como a geração das residências "neocoloniais tardias" ou "rústicas", típicas dos grandes sobrados construídos nos bairros da parte sul da cidade durante aquele período ${ }^{43}$. Por fim, nos condomínios fechados, desde o final da década de 90 até hoje vigora o estilo que pode ser denominado como "moderno tardio".

Quanto aos edifícios verticais, além da classificação do estilo arquitetônico e da busca de datação de edificações e da formação de aglomerados desses imóveis, é possível também descrever "gerações de altura",44 das edificações, pois os primeiros edifícios verticais de Goiânia possuíam apenas três andares. Foi apenas no período do estilo arquitetônico moderno que a legislação urbana passou a permitir a construção de prédios mais altos do que oito andares ${ }^{45}$, que podem ser observados nas fotos tipo "vôo

\footnotetext{
${ }^{42}$ O IPHAN considera as casas-tipo construídas pelo estado como residências no estilo art-déco, mas essa classificação não é consensual nas pesquisas acadêmicas que abordam o tema. Para uma crítica à classificação dos imóveis projetados por Attilio Corrêa Lima no estilo art-déco, cf. Diniz 2007.

${ }^{43}$ Com a exceção do Setor Jaó, na parte norte da cidade, bairro que, nos termos de Villaça, se tornou "fora de mão" para a classe dominante do espaço urbano, na medida em que o centro se expandiu na direção oposta à de sua localização. De qualquer modo, os exemplos mais imponentes dessas residências se concentram claramente nos Setores Oeste, Bueno e Marista, todos na parte sul da cidade, como se observa em campo.

${ }^{44} \mathrm{Ou}$ de progressão do número de pavimentos das edificações.

${ }^{45}$ No entanto, ainda que nas décadas iniciais da cidade houvesse a possibilidade legal de construção de edifícios de até oito pavimentos, os edifícios possuíam, em geral, a altura máxima de três pavimentos (Medeiros 2002: 168).
} 
de pássaro", tiradas entre as décadas de 50 e 70, com as alturas variando entre sete ${ }^{46}$ e quinze andares ${ }^{47}$ nos exemplares mais altos. A "geração de altura" seguinte, cujos exemplares foram construídos entre as décadas de 70 e 90, apresenta edifícios de até 24 $\operatorname{andares}^{48}$. A última "geração de altura" de edifícios verticais de Goiânia, representada por um alto índice de construções, após um período de baixa entre meados dos anos 90 e meados da primeira década do século XXI, oferece dezenas de exemplares de edifícios com mais de 30 andares, muitos deles em construção no presente momento ${ }^{49}$.

A periodização levou ao estabelecimento de cinco fases da história arquitetônica dos imóveis de alto padrão de Goiânia: A fase "0”, que inclui os imóveis produzidos pelo Estado de acordo com o planejamento original da cidade, a fase "1", que corresponde aos imóveis produzidos entre as décadas de 30 e 50, a fase "2", que corresponde aos imóveis produzidos entre as décadas de 50 e 70, a fase “3”, que corresponde aos imóveis produzidos entre as décadas de 70 e 90 , e a fase "4", correspondente aos imóveis produzidos nas últimas décadas.

e) Escalonamento: A pesquisa trabalhou com diferentes níveis de associação dos imóveis urbanos. O nível mais básico é o dos imóveis propriamente ditos, ou das unidades urbanas, elementos básicos da estrutura urbana. Foi possível assim identificar e mapear imóveis individualmente, como por exemplo, as casas construídas no estilo moderno por arquitetos renomados nas décadas de 50,60 e 70 e listadas por autores pesquisados. Com a obtenção de sua localização exata, a casa identificada pôde ser marcada como um ponto no mapa de fundo.

\footnotetext{
${ }^{46}$ Edifício do Banco do Estado de Goiás, construído na Praça do Bandeirante na virada da década de 50 para a de 60 (Medeiros 2010: 231).

${ }^{47}$ Edifício residencial construído em 1977 no Setor Aeroporto (Silva Neto 2010: 36).

${ }^{48}$ Edifícios do Condomínio Vaticano, situados no Setor Bueno.

${ }^{49}$ A baixa no mercado imobiliário goianiense foi citada pelos corretores imobiliários entrevistados e pode ser aferida nos arquivos da ADEMI, que lista o volume da produção de edifícios verticais a partir do início dos anos 90.
} 


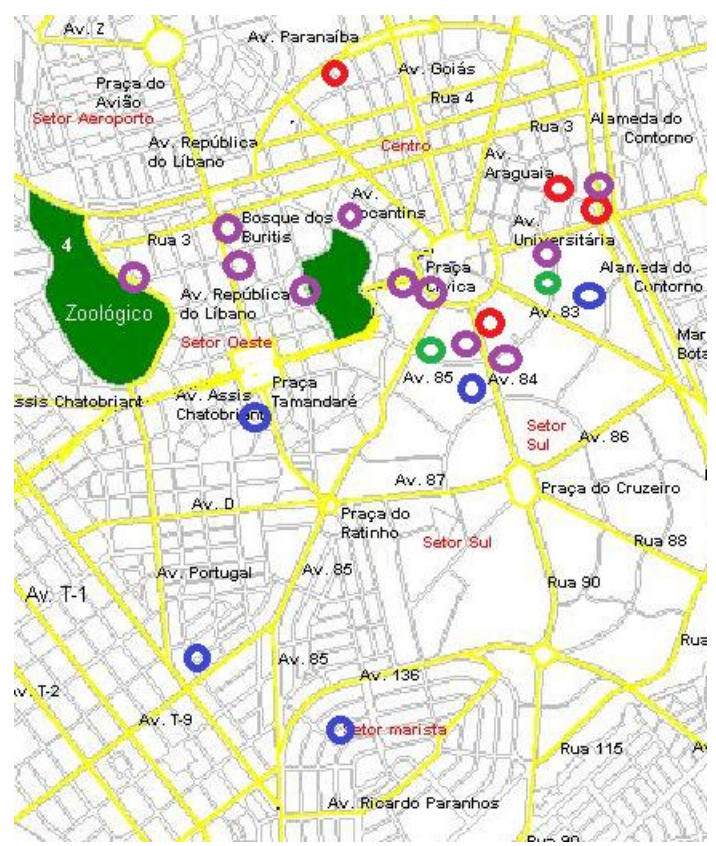

Figura 8. As residências modernas indicadas pelos autores pesquisados. Em vermelho, as residências de alto padrão construídas na década de 50, uma delas situada no Setor Sul, próxima à Praça Cívica. Outra se situa na Rua 20 e uma terceira próxima ao Córrego Botafogo. Uma delas é "excêntrica", situada ao norte da avenida Anhanguera. As residências de alto padrão construídas na década de 60, em roxo, se distribuem, em sua maioria, próximas à Praça Cívica, mas já no Setor Sul, e em três áreas no Setor Oeste ou adjacentes a este bairro: em torno do Bosque dos Buritis, na avenida República do Líbano e diante do Lago das rosas. Em azul, as casas construídas já na década de 70 se apresentam no Setor Sul, ainda próximas ao núcleo da Praça Cívica e ao longo das áreas de expansão ao sul que se desenvolveram a partir do Setor Oeste. Fica evidente aqui que os limites iniciais do Setor Central inicialmente implantado só são ultrapassados pelas residências de alto padrão, confirmadas pela pesquisa, a oeste e ao sul, a partir da década de 50 e principalmente nas décadas de 60 e 70 . O Setor Sul é o bairro que possui o maior número de casas modernas indicadas, mas todas elas estão situadas próximas à Praça Cívica, enquanto nota-se na década de 70 um notável avanço para o sul a partir do Setor Oeste. Em verde, temos os dois exemplos de residências "fachadistas" de padrão médio apresentados por Silva Neto (2010), que confirmam a proximidade destas com as residências de alto padrão no Setor Sul.

O nível seguinte é o dos imóveis associados de primeiro grau, que permite descrever conjuntos básicos de imóveis associados. Esse nível corresponde à escala de descrição de núcleos, faixas e áreas residenciais. Identificados enquanto conjuntos de unidades básicas, esses elementos compostos são representados de acordo com suas características de tipo ou qualidade sobre o mapa de fundo.

O terceiro nível é o dos imóveis associados de segundo grau, os distritos, que são representados como conjuntos de imóveis associados de primeiro grau.

O quarto nível corresponde à escala dos imóveis associados de terceiro grau, os setores, que por sua vez, são conjuntos qualificados de distritos. Os setores são representados de modo semelhante ao modelo de representação da estrutura urbana desenvolvido por Hoyt (1939) e utilizado por Villaça para representar as "estruturas espaciais de algumas áreas metropolitanas" brasileiras (Villaça 2001:115). 
O quinto nível de associação corresponde à escala dos imóveis urbanos associados de quarto grau, os círculos concêntricos, conhecidos popularmente como centro e periferia. Trata-se de uma divisão semelhante, embora com números de círculos diferentes, ao modelo concêntrico da estrutura urbana clássico, apresentado por Burgess (1970: 363).

f) Os padrões e hábitos de sociabilidade associados aos imóveis de alto padrão: Um procedimento importante é aquele que visa obter alguma compreensão das maneiras como os imóveis urbanos de alto padrão são utilizados pelos grupos sociais. Isso se refere a relações de vizinhança e a atividades específicas, como o trabalho, o lazer e a educação. Não foi possível, dadas às dimensões da pesquisa, dar conta de uma análise detalhada dessas atividades. Mas, ainda assim, algumas associações puderam ser realizadas, principalmente através da investigação de fontes bibliográficas e, secundariamente, através de tomada de entrevistas e de observações de campo.

Com esse procedimento foi possível registrar a prática do footing no centro de Goiânia, entre as décadas de 30 e 60, e a posterior prática do "footing motorizado", entre as décadas de 70 e 90 , respectivamente ${ }^{51}$. Na medida em que tais práticas possam ser situadas pela pesquisa empírica, é possível também associá-las aos elementos urbanos que as situam. Outro procedimento similar foi o da análise dos mapas de memória de antigos moradores de Goiânia, apresentada por Medeiros (2007), que indicou uma compreensão simbólica diferenciada da estrutura urbana por parte de pessoas de diferentes classes sociais. Os mapas de memória de indivíduos da elite mostram um maior reconhecimento da simbologia hierárquica presente no plano diretor original da cidade, enquanto o mapa de um indivíduo da classe trabalhadora mostra um distanciamento desse quadro de referência.

\subsection{Exemplo de aplicação do método descritivo e cartográfico}

Aqui a aplicação do método descritivo será exemplificada com a descrição da estrutura urbana focada nos imóveis de alto padrão, nas fases " 0 " e "1" da história arquitetônica de Goiânia, conforme estabelecidas pela periodização acima.

\subsubsection{A hierarquia no planejamento original da cidade}

\footnotetext{
${ }^{50}$ Foi denominado assim o tipo de prática social de lazer relacionado ao uso do automóvel.

${ }^{51}$ Cf. Oliveira 1999.
} 
O plano-piloto, ou Plano de Urbanização de Goiânia, aprovado pelo decreto-lei 90-A, de 1938, estabelece uma visível divisão hierárquica das áreas residenciais e também das áreas não residenciais, conforme as distribui no traçado urbano. Constam nos projetos aprovados três bairros da cidade central ou principal, os Setores Central, Norte e $\mathrm{Sul}^{52}$, sendo o último destinado a uma implantação futura, após o adensamento dos dois primeiros bairros a serem loteados e comercializados por iniciativa do governo estadual, proprietário das terras designadas (Bernardes 2007: 97).

A cidade foi prevista em três estágios de crescimento. No primeiro estágio seriam implantados os Setores Central e Norte. Em um segundo estágio, quando a população dos dois primeiros Setores (bairros) atingisse os 15.000 habitantes, seria implantado o setor sul. Por fim, em um terceiro estágio não datado, seria implantado o Setor Oeste (Gonçalves 2002: 49). A população máxima seria de 50.000 habitantes, e um cinturão verde de parkways marcaria os limites definitivos da cidade principal, que ocuparia o centro de um sistema de cidades-satélites ${ }^{53}$ (Bernardes 2007: 96).

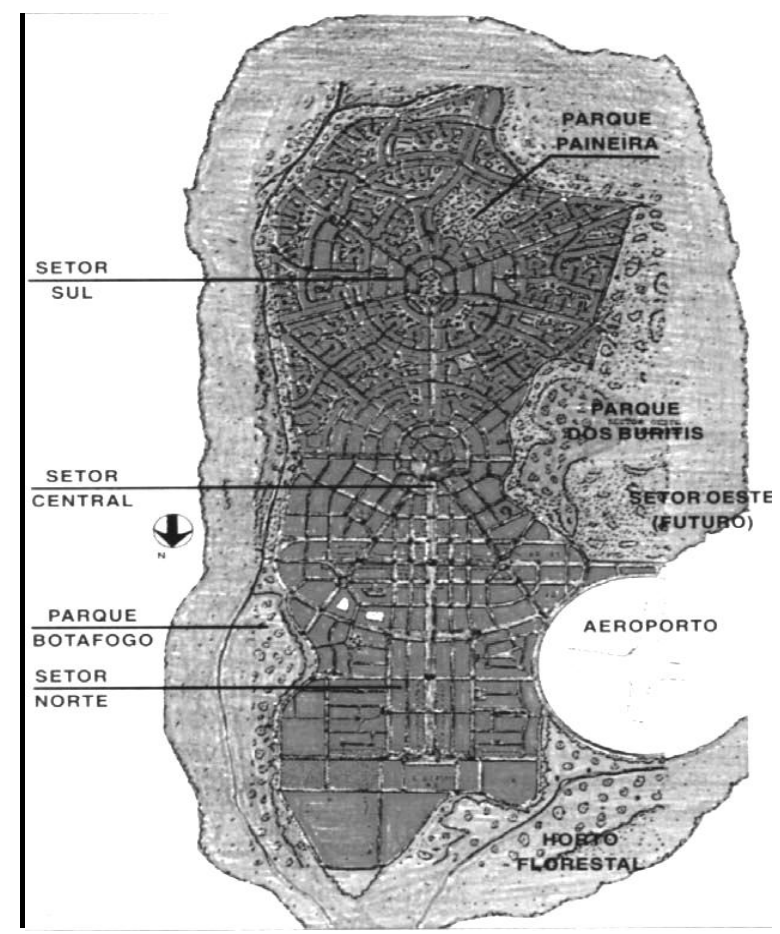

Figura 9. A cidade principal do município de Goiânia de acordo com o primeiro plano diretor, de 1938. O modelo representa três momentos: a implantação inicial dos setores Norte e Central, a implantação do

\footnotetext{
${ }^{52}$ Além de um quarto bairro não projetado, o Setor Oeste.

${ }^{53}$ Uma dessas cidades-satélites, Campinas, tinha existência prévia como sede municipal, sendo reduzida a cidade-satélite e depois, com a não ocorrência do sistema policêntrico previsto e sua conurbação com a cidade principal, a bairro de Goiânia. Campinas foi, de fato, a única cidade-satélite de Goiânia.
} 
Setor Sul e a ainda posterior implantação do Setor Oeste. Há também a típica apresentação "invertida" dos projetos iniciais de Goiânia, com a parte sul da cidade voltada para cima. Fonte: SEPLAM

Afirmo que a hierarquização do plano é clara devido à relação que ele estabelece entre categorias de estratificação social, a distribuição geográfica das residências e a distribuição geográfica das edificações não residenciais.

Nos textos dos planejadores de Goiânia, há três categorias sociais indicadas: a “elite", os "funcionários" e os "operários". A “elite” é referida em relação à prática de uma atividade de lazer, o footing, situada nas proximidades da Praça Cívica, e em relação à disponibilidade de "civilização" de que necessita ${ }^{54}$. Os "funcionários" e "operários" são categorizados em relação às residências que deveriam ocupar, nomeadas "casas-tipo funcionário" e "casas-tipo operário" (Cf. Alvares 1942). Essas três categorias sociais e residenciais estavam também associadas a funções de centralidade que estavam distribuídas ao longo de um eixo que partia do norte para o sul, acompanhando um suave aclive e tendo como ponto mais alto a Praça Cívica, para onde converge um sistema de três bulevares, do tipo "pé de pato":

Da topografia tiramos partido também para realçar o principal motivo da cidade que é o seu centro administrativo. Quem atravessar a cidade ao longo da sua principal via comercial (Avenida Anhanguera) verá sucessivamente três pontos de vista diversos ao cruzar as três grandes avenidas que convergem para aquele centro. Procuramos adotar o partido clássico de Versailles, Carlsruhe e Washington, genericamente chamado de 'pate d'oie' pelo aspecto monumental e nobre, como merece a capital de um estado (evidentemente que guardando as devidas proporções). (Relatório de Attilio Corrêa Lima de 1933, apud Cordeiro 1990: 19).

Pode-se dizer que o planejamento inicial da cidade era hierárquico em sua funcionalidade, pois as categorias sociais indicadas estavam em uma associação espacial com atividades específicas. Assim, o Setor Norte, que viria a ser conhecido como "Bairro Popular", se situaria próximo das áreas reservadas à indústria e à

\footnotetext{
54 “Adotamos espaços livres a fim de utilizar a Avenida Pedro Ludovico como jardim. Por isso demos a largura excepcional para uma aglomeração relativamente modesta. Apresenta esta com os seus $45 \%$ de área ajardinada e convenientemente arborizada, aspecto monumental e pitoresco. É futuramente o local onde a elite fará o footing à tarde e à noite" (Relatório de Attilio Corrêa Lima de 1933, apud. Cordeiro 1990: 21). “(...). Onde se estabelece uma cidade moderna e bem aparelhada, surge a trindade econômica sôbre que se baseia a atividade material, que é ao mesmo tempo industrial, bancária e comercial, valorizando a terra numa grande extensão e evitando o êxodo das fortunas que nela se formam, bem como a emigração de seus habitantes, principalmente dos que constituem a elite, os quais, é natural, só se sentem bem onde encontram campo vasto para suas atividades espirituais" (Relatório de Armando de Godói de 1933, apud Cordeiro 1990: 13).
} 
implantação de um eixo ferroviário leste-oeste, e seria o local de moradia de "operários" 55.

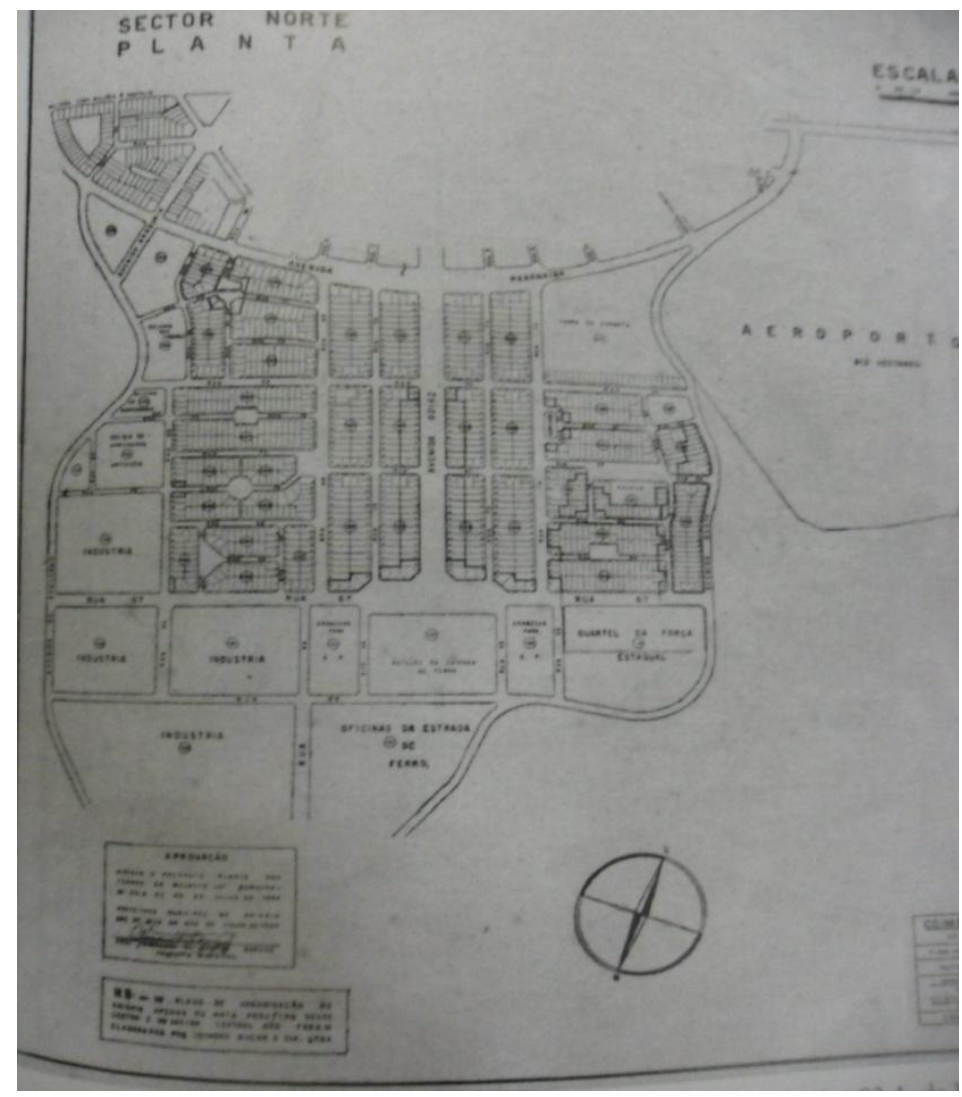

Figura 10. O Setor Norte de Goiânia, de acordo com o primeiro plano diretor, mostrado com a parte sul voltada para cima. O extremo norte é a parte mais baixa da cidade, próxima ao rio Meia Ponte, que corre no sentido leste-oeste, o mesmo sentido da estrada de ferro, que não foi inicialmente implantada. No ponto inicial da Avenida Goiás, há o local destinado à futura estação ferroviária. Na parte norte, os amplos terrenos são destinados a instalações industriais (que nunca ocuparam significativamente a área) e ferroviárias. Traçada na Avenida Goiás, há uma área destinada ao comércio e à indústria ligeira. Trata-se de um bairro residencial nucleado em torno de áreas ferroviárias, industriais e comerciais. Fonte: SEPLAM

Entre a idealização de uma elite que pratica o footing diante do centro monumental e ponto culminante da cidade - além de sede do poder político - e aquela de operários residindo perto de seu local de trabalho na parte baixa da cidade, foi disposta a função "geradora de fortunas" do comércio central, distribuída ao redor do principal cruzamento da cidade, entre a avenida Goiás (inicialmente chamada de avenida Pedro Ludovico) eixo principal do sistema urbano da cidade, e a avenida

55 “Os operários necessitam residir próximo de suas fábricas - isto lhes poupará despesas de tempo e de transporte. Também não devem, como ninguém deve, residir nas vizinhanças inconfortáveis e insalubres das fábricas. Estabelecemos, então, as subzonas [residenciais] operárias, adjacentes à zona de indústrias suficientemente aproximadas para só conduzirem para elas".(Relatório da construtora Coimbra Bueno, de 1937, apud Cordeiro 1990: 13). 
Anhanguera que corre no sentido leste-oeste e se conecta com a rodovia que ligava Goiânia a outras cidades, a leste, e à cidade-satélite de Campinas, a oeste.

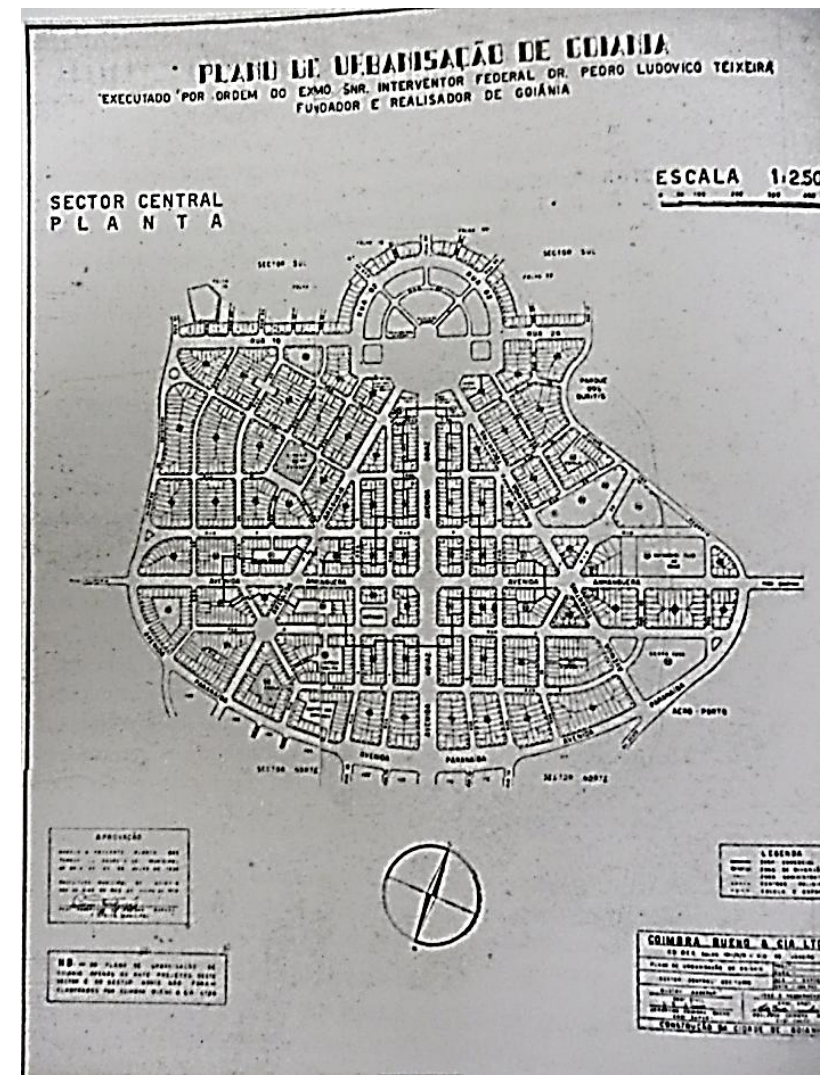

Figura 11. Planta do Setor Central de Goiânia, de acordo com o primeiro plano diretor. No topo do mapa, na parte mais alta da cidade, há o centro cívico e governamental. No centro, nota-se a área destinada ao comércio, traçada em torno do cruzamento das duas avenidas principais. Trata-se de um bairro residencial nucleado em torno de imóveis governamentais e comerciais. Fonte: SEPLAM

Esse centro comercial é também qualificado pelos projetistas, que conceberam o comércio de alto padrão ao longo do eixo monumental norte-sul, na parte sul da avenida Goiás, em direção ao centro administrativo que coroa a cidade. Além disso, a atividade bancária ficaria restrita ao trecho central da primeira rua ao sul da avenida Anhanguera, a rua $3 .^{56}$

A construção das primeiras casas e edifícios da cidade, produzidas por empreiteiras contratadas diretamente pelo governo estadual seguiu esse padrão, produzindo e distribuindo, respectivamente, “casas operárias" no Setor Norte, “casas

56 “O trecho da rua 3, compreendido entre as ruas 6 e 9, é destinado exclusivamente à zona bancária. (...) Na Avenida Pedro Ludovico só deverá ser tolerado o comércio de luxo, casas de modas, joalherias, cafés, bares e restaurantes com instalações de gôsto". (Relatório de Attilio Corrêa Lima, 1933. Apud Cordeiro 1990: 25). 
para funcionários" na parte norte do Setor Central e "casas-tipo" na parte sul do Setor Central, como veremos adiante.

Há assim, no projeto aprovado em 1938 e na literatura dos planejadores, a concepção de uma cidade com áreas de expansão programadas, mas também com limites de expansão pré-fixados, cujas áreas residenciais se dispunham sobre um eixo principal norte-sul, ao longo do qual foram dispostos:

a) um núcleo industrial-ferroviário e de comércio qualificado,

b) duas faixas comerciais centrais qualificadas,

c) um núcleo governamental,

d) um núcleo religioso a ser implantado em um segundo momento, como elemento central do Setor Sul.

É preciso lembrar que o plano-piloto de 1938 modificou alguns aspectos dos projetos originais de Attilio Corrêa Lima ${ }^{57}$, alterando totalmente o traçado do futuro Setor Sul e atribuindo fronteiras fixas à cidade (Gonçalves 2002: 54-55; 58-68). Nos desenhos de Attilio não havia nenhum centro religioso previsto em destaque. Na versão de Attilio, o eixo norte-sul principal não se estendia para o sul da Praça Cívica e esta se mostrava claramente como a "cabeça" da cidade, ocupando com suas funções de governo, o topo da hierarquia funcional planejada ${ }^{58}$. No entanto, os desenhos de Attilio já mostram uma disposição geral de áreas residenciais qualificadas e dispostas em torno de núcleos não residenciais: industriais, comerciais e governamentais.

${ }^{57}$ Attilio Corrêa Lima, o arquiteto contratado para a elaboração dos planos e a direção técnica das obras da cidade, foi afastado em abril de 1935. No seu lugar, foi contratado o engenheiro Armando de Godoy (Diniz 2007: 190). De acordo com Gonçalves, a equipe técnica da empresa contratada pelo Estado para a realização das obras (a construtora Coimbra Bueno), foi a maior responsável pelas alterações nos projetos originais, pois Godoy residia no Rio de Janeiro e esteve relativamente ausente dos trabalhos de planejamento. No caso da reformulação do Setor Sul, conforme o depoimento dos irmãos Coimbra Bueno registrado por Gonçalves, Godoy apenas deu aos técnicos da equipe "uma revista americana" (Gonçalves 2002: 54).

58 "Goiânia teve, no Centro Cívico, a origem de seu traçado: tudo convergia para lá e de lá partiam avenidas e ruas; o simbolismo dos rios Araguaia, Tocantins e Paranaíba, transformados em avenida, bem como da Avenida Goiás, parece ir além do mero símbolo, da mera arquitetura. Do Centro Cívico, visto na perspectiva do poder executivo, ali representado, partiam as diretrizes para a capital e para o estado de Goiás" (Campos 1998; apud Bernardes 1998: 201). 


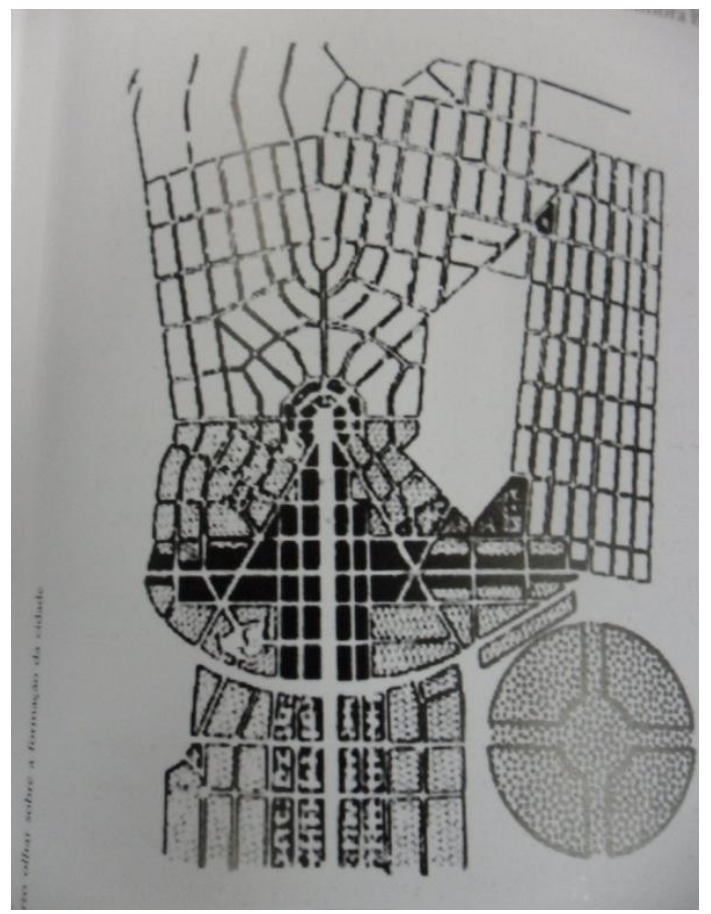

Figura 12. Projeto original de Attilio Corrêa Lima, em um desenho que destaca o zoneamento proposto pelo arquiteto. Notar o traçado mais convencional e a ausência de uma praça central no Setor Sul, que possui suas vias em conversão para a Praça Cívica, ponto central da cidade. Com isso, há a forma de uma ampulheta. Em preto está representado o zoneamento comercial. No Setor Norte (voltado para baixo), acompanhando o eixo da avenida Goiás abaixo da área comercial, há a área industrial. As áreas residenciais em cinza são consideradas áreas residenciais urbanas e as áreas residenciais em branco, nos futuros setores Sul e Oeste, são consideradas suburbanas, dotadas de terrenos maiores, o que levaria a uma menor densidade demográfica nessas áreas. A cidade não tem limites fixos e o círculo no canto noroeste, abaixo na figura, é o aeroporto. Fonte: Daher 2003.

Com o primeiro plano diretor aprovado, há o projeto de um distrito cujo sentido do desenvolvimento dos imóveis de alto padrão aponta para o sul (com uma ligeira inclinação para sudeste), e cuja possibilidade geral de crescimento se encontra rigidamente limitada por um cinturão verde de parkways. A parte ao sul da Praça Cívica, reservada para a futura instalação de imóveis de alto padrão, constitui a área mais bem provida de espaço de crescimento dentro desses limites pré-estabelecidos, e a única área destinada a expansões futuras que possuía já um projeto (cf. figura 9). Esse crescimento para o sul seria também o resultado de um grande lançamento imobiliário do Estado, o lançamento do bairro-jardim que viria a ser denominado Setor Sul (ou “Zona Sul”, como aparece nas primeiras referências ao projeto), conforme pode ser observado no discurso dos planejadores:

A Zona Sul, graças à orientação do Dr. Godoy, teve o projeto feito nos moldes do subúrbio de "Redburn", que os milionários americanos construíram nas vizinhanças de New York, essencialmente para residências. Assim, projetamos, com o auxílio do Dr. Werner Sonemberg, este setor, e pretendemos projetar o "Setor Oeste". (...) Na Zona Sul é que surgirá a mais moderna solução urbanística do momento atual. (Relatório da construtora Coimbra Bueno, de 1937, apud Cordeiro 1990: 27). 


\subsubsection{A estruturação da cidade até o início da década de quarenta}

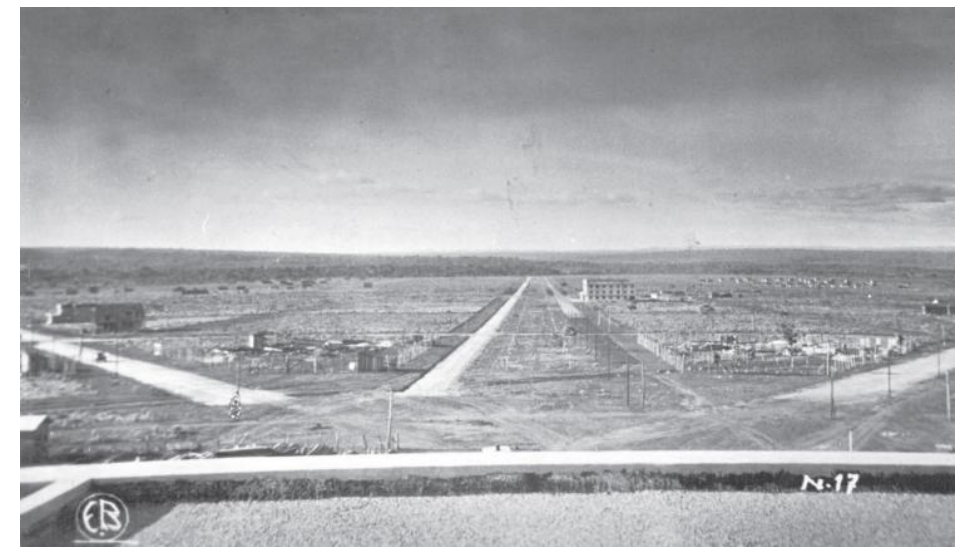

Figura 13. Vista para o norte a partir do teto do Palácio das esmeraldas, mostrando a avenida Goiás em 1937. A paisagem é desolada, todavia mostra já o resultado do planejamento concebido por Attilio Corrêa Lima e pelos continuadores de sua obra. Adiante do palácio do governo, edifícios públicos começam a ser erigidos. O edifício isolado na avenida Goiás, no centro da foto, é o Grande Hotel, notado por LéviStrauss. Ao fundo, no lado direito, nota-se o aglomerado de casas operárias do Setor Norte. Fonte: SEPLAM.

Mais ou menos no terço da distância que separa, em linha reta, o Amazonas da costa meridional, estendem-se vastos planaltos há dois séculos esquecidos pelo homem. No tempo das caravanas e da navegação fluvial, podia-se atravessá-los em algumas semanas, para subir das minas na direção norte; ganhavam-se assim as margens do Araguaia, que se descia em barco ate Belém. Único testemunho dessa antiga vida provincial, a pequena capital do estado de Goiás, que lhe deu o nome, dormia a 1.000 quilômetros do litoral, de que estava praticamente cortada. Num lugar verdejante, dominado pela silhueta caprichosa dos morros empenachados de palmeiras, filas de casas baixas desciam pelas encostas, entre os jardins e as praças em que os cavalos pastavam diante das igrejas de janelas ornadas, meio granjas e meio casas com torres. Colunatas, estuques, frontões, sempre pintados de fresco de uma tinta espumosa como clara de ovo e matizada de creme, de ocre, de azul ou de rosa, evocavam o estilo barroco das pastorais ibéricas. Um rio deslizava entre cais limosos, às vezes desmoronados ao peso dos cipós, das bananeiras e das palmeiras que tinham invadido as residências abandonadas; mas essa vegetação suntuosa parecia menos marcar estas últimas com o sinal da decrepitude do que acrescentar uma dignidade silenciosa às suas fachadas envelhecidas.

Não sei se nos devemos regozijar com o absurdo ou deplorá-lo: o governo tinha decidido esquecer Goiás, seus campos, seus declives e sua graça fora de moda. Tudo aquilo era demasiadamente pequeno, velho demais. Seria preciso uma tábua rasa para fundar o gigantesco empreendimento que se sonhava. Foi encontrada a cem quilômetros para leste, sob a forma dum planalto coberto somente de capim duro e de espinheiras, como se tivesse sido atingido por um flagelo destruidor de toda a fauna e inimigo da vegetação. Nenhuma via férrea, nenhuma estrada de acesso, apenas algumas trilhas próprias para carroças. (...) Como nenhum acidente natural existisse para importunar os arquitetos, estes últimos puderam trabalhar sobre o terreno como se o fizessem em suas pranchetas. $\mathrm{O}$ traço da cidade foi desenhado na terra; delimitou-se o contorno, e, no interior, as diferentes zonas: residencial, administrativa, comercial, industrial e a que se consagrou às distrações. (...)

Do dia para a noite, os jornais se cobriram de anúncios de página inteira. Anunciava-se a fundação da cidade de Goiânia; em torno de um plano pormenorizado, como se a cidade fosse centenária, enumeravam-se as vantagens prometidas aos habitantes: limpeza pública, estrada de ferro, água e esgotos, cinemas. Se não me engano, houve mesmo, no início, em 1935-36, um 
período em que se oferecia terra como premio aos compradores que concordassem em pagar as despesas de escritura. Pois os notários e especuladores eram os primeiros ocupantes.

Visitei Goiânia em 1937. Uma planície sem fim, que parecia, ao mesmo tempo, um terreno baldio e um campo de batalha, eriçada de postes de eletricidade e de estacas de agrimensura, exibia uma centena de casas novas dispersas pelos quatro cantos do horizonte. A mais importante era o hotel, paralelepípedo em cimento, que, no meio desse achatamento, evocava uma aero-estação ou um fortim; ter-se-lhe-ia aplicado de boa vontade a expressão "bastião da civilização", dum sentido não mais figurado mas direto, que adquiria, com esse uso, um valor singularmente irônico. Pois nada poderia ser tão bárbaro, tão inumano, quanto esse empreendimento contra o deserto. Essa construção sem graça era o contrário de Goiás; nenhuma história, nenhuma duração, nenhum hábito havia saturado o seu vazio ou amenizado a sua rigidez; sentimo-nos ali como numa estação ou num hospital, sempre passageiros e jamais residentes. Somente o temor dum cataclismo poderia justificar essa casamata. Produziuse um, com efeito, cuja ameaça se prolongava no silêncio e na imobilidade reinantes. Cadmus, o civilizador, tinha semeado os dentes do dragão. Numa terra esfoliada e queimada pelo hálito do monstro, esperava-se que nascessem homens. (Lévi-Strauss 1957: 126-128).

Essa passagem de Tristes Trópicos descreve Goiânia em seus primeiros anos, marcados pelas obras de construção das primeiras edificações. Esse foi um período em que o núcleo inicial ainda tinha um aspecto pouco adensado e a planície nua, somada à poeira e ao calor seco do Brasil Central conjugavam para dar ao conjunto um aspecto desolado. Esse aspecto desolado não existe mais nas áreas centrais da cidade, mas continuará ainda presente ao longo sua história, nas áreas de expansão dos seus limites urbanos, em sua periferia, caracterizada pela baixa taxa de densidade de ocupações e pela pouca infra-estrutura implantada.

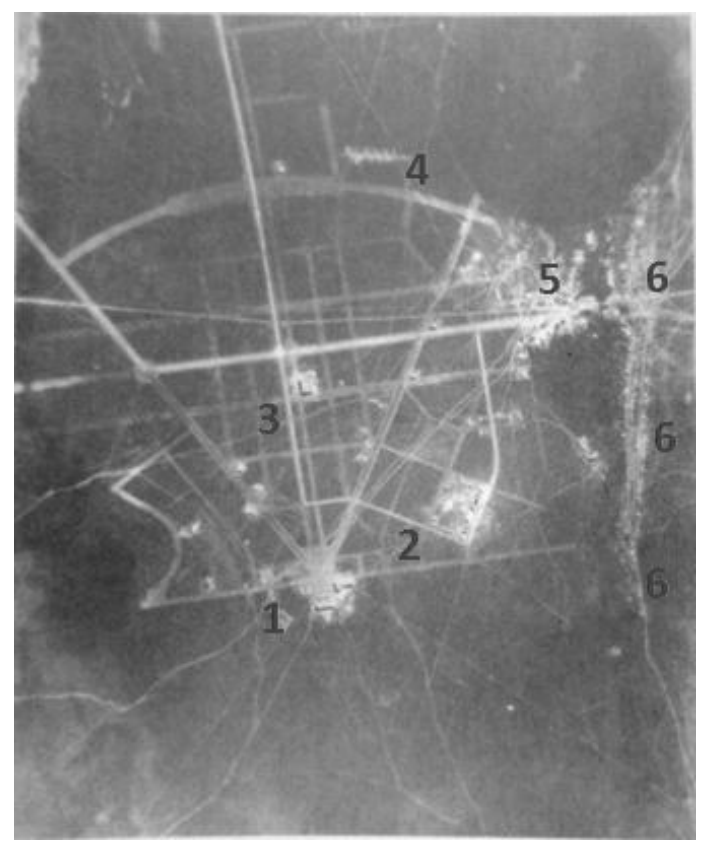

Figura 14. Fotografia aérea de Goiânia do ano de 1936. 1: a Praça Cívica. 2: a rua 20. 3: O Grande Hotel. 4: a rua 71. 5: o acampamento da equipe de construção. 6: extensão do acampamento, com edificações improvisadas ao longo do Córrego Botafogo. 
A) O acampamento às margens do Córrego Botafogo:

Antes de abordar a cidade planejada, devo lembrar que o primeiro bairro que surgiu em Goiânia situava-se no local que foi construído o acampamento dos construtores da cidade, onde "os primeiros habitantes de fato fizeram suas casas de pau a pique e palha às margens do Córrego Botafogo, fonte de água potável” (Lima Filho 2007: 249).

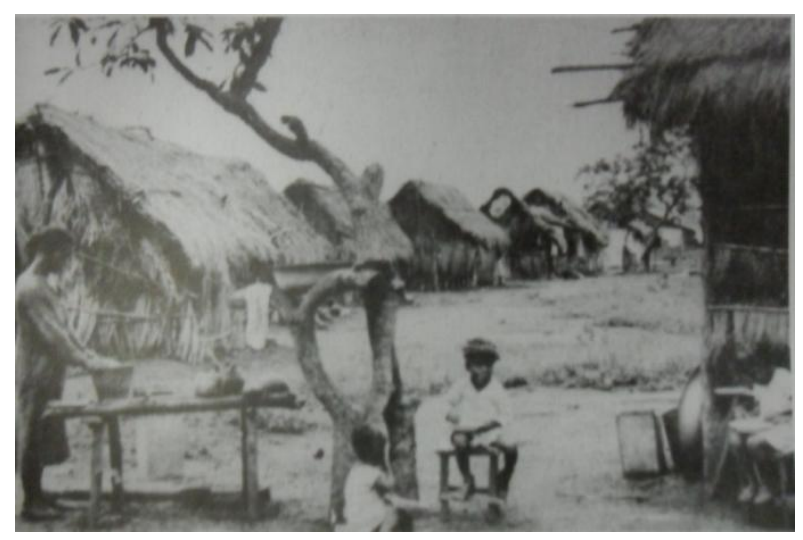

Figura 15. Construções improvisadas junto ao Córrego Botafogo em fotografia da década de 30. O padrão mais baixo de moradia construída não estava previsto no plano da cidade, mas preexistiu à sua implantação. Fonte: SEPLAM

Por um curto período de tempo, até o término da construção das primeiras casas-tipo especial na rua 20, o acampamento abrigou funções públicas e moradores ilustres, como o interventor do estado e fundador de Goiânia, Pedro Ludovico. O acampamento não foi desmantelado, mas se converteu em bairro ilegal, o Bairro Botafogo, que se estendeu notavelmente ao longo das margens córrego Botafogo, ocupando praticamente todo o limite leste da cidade planejada. Com o tempo, partes do bairro foram legalizadas através de doações e relocações com serviços de urbanização, e outras partes foram removidas para a instalação de loteamentos e para a urbanização das áreas públicas das margens do córrego, restando atualmente alguns poucos fragmentos de ocupações ilegais na área (Cf. Gonçalves 2002, Bernardes 2000).

B) A rua 20: 


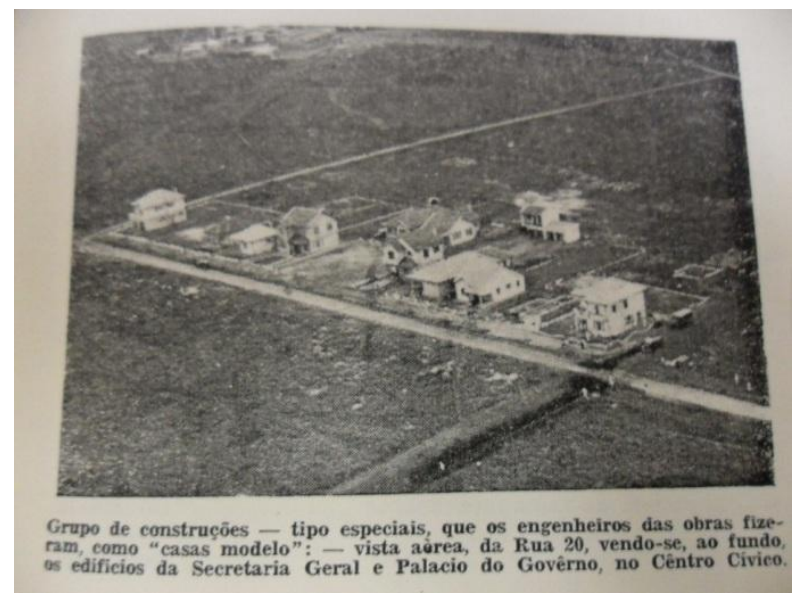

Figura 16. A rua 20 na década de 30, com suas casas-tipo especiais, que recebeu pioneiros ilustres e escritórios do governo. Trata-se da primeira faixa de alto padrão de Goiânia. Fonte: Alvares 1942.

De acordo com Monteiro (1938: 151), a rua 20 foi "a primeira rua de Goiânia", pois as dez residências ali situadas e um jardim de infância foram as primeiras edificações não improvisadas a serem construídas, no ano de $1935^{59}$. Nesse local foram construídas as residências menos padronizadas e de mais alto custo de produção dentre as primeiras residências construídas na cidade (cf. Alvares 1942). Essas construções foram denominadas "casas tipo", "casas-tipo especial" ou "casas-modelo" e consideradas por seus criadores um modelo a ser seguido, como pode ser extraído do relatório dos irmãos Coimbra Bueno, enviado à Superintendência Geral de Obras do Estado em junho de 1936:

(...) considerando que estas obras são as primeiras aqui edificadas, elas [as casas-tipo especial] têm, portanto uma função altamente educativa. Elas representam os marcos de um avanço que a administração actual vai dando à civilização do Estado, e portanto, devem ser colocadas no ponto mais próximo possível dos fins colimados: a sincronização de nosso progresso com o dos centros mais avançados do Brasil; e assim, impressionar bem fundo o espírito de nossa gente para fazê-las sentir com a evidência dos factos o quanto nós estamos atrazados em relação àqueles centros, e com argumento insofismável das cousas feitas, convencê-los que este avanço que se tenta é realizável (apud Gonçalves 2002: 82).

As residências da rua 20, ao contrário das outras construídas no período, possuíam projeto e acabamento diferenciados, sendo em sua maioria destinadas a pessoas notáveis do círculo do interventor estadual Pedro Ludovico, sendo que ele próprio passou a ocupar a casa tipo número oito em dezembro de $1935^{60}$.

\footnotetext{
${ }^{59}$ Antes (1933-34) havia sido construído, como primeira medida, o já referido acampamento nas margens do córrego Botafogo, com edificações provisórias distintas para escritórios, depósitos, oficinas e habitações para operários e técnicos (Gonçalves 2002: 135).

${ }^{60}$ Pedro Ludovico teve três locais de residência em Goiânia, o primeiro local foi uma casa de madeira no acampamento das obras no Córrego Botafogo, onde funcionou um "palácio do governo" improvisado (Santana, Bonetti e Macêdo 2007: 165). O segundo local de Residência foi a acima referida casa "tipo
} 


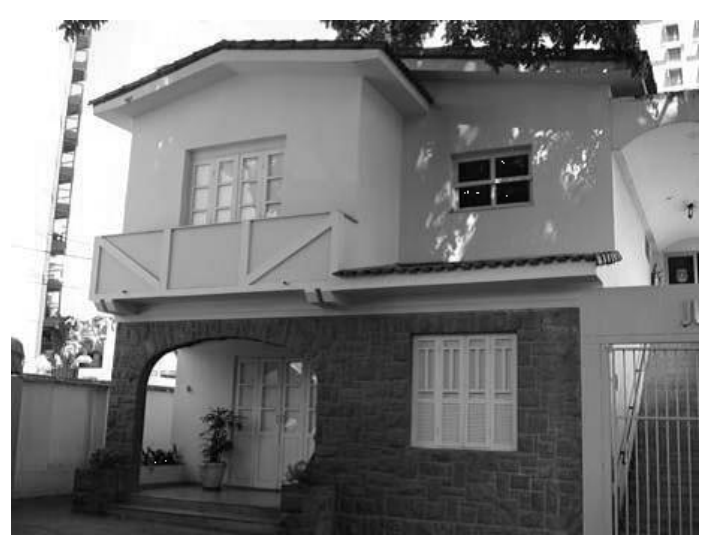

Figura 17. Casa-tipo especial número 8, rua 20. Tombada pelo IPHAN, foi residência de Pedro Ludovico e depois abrigou a Faculdade de Direito. Fonte: Oliveira e Silva 2006.

Essa faixa residencial do mais alto padrão se associou também a funções do poder, que ali se instalaram provisoriamente, enquanto os edifícios da Praça Cívica estavam em construção.

Pode-se dizer, portanto, que na rua 20 se situou a primeira área residencial de mais alto padrão de Goiânia, na forma de uma faixa. A relação de proximidade com o poder político de seus primeiros moradores transparece, por exemplo, no trecho de depoimento de Dona Maria de Godoi Carvalho, coletado por Santana, Bonetti e Macêdo (2007: 165): “A vizinhança na rua 20 era uma maravilha. O contato era muito bom e era gente também do nível que a gente veio. Porque se tratava de pessoas que estavam mais próximas do doutor Pedro. Porque ele mesmo morou na rua 20".

De acordo com Lima filho (2007: 251), na rua 20:

(...) estavam concentrados valores considerados importantes: a igreja (na rua 20 morava o Bispo e ao lado foi construída a Catedral de Goiânia ${ }^{61}$ ), o Palácio do Governo [que funcionou ali temporariamente, até a inauguração do Palácio das Esmeraldas], a Faculdade de Direito e o Conservatório de Música, o Jardim de Infância, entre outros. Portanto, morar na rua 20 era morar perto do poder e do prestígio.

especial" número oito, que ele habitou por alguns anos, antes de se mudar para sua residência definitiva, próxima à Praça Cívica. A casa tipo, após a mudança de Pedro Ludovico, passou a abrigar a Faculdade de Direito, embrião da futura Universidade Federal de Goiás (Gonçalves 2002; Oliveira 1999).

${ }_{61}$ Embora programada para a Praça do Cruzeiro, a catedral foi construída na avenida 10, nas proximidades da rua 20 . 


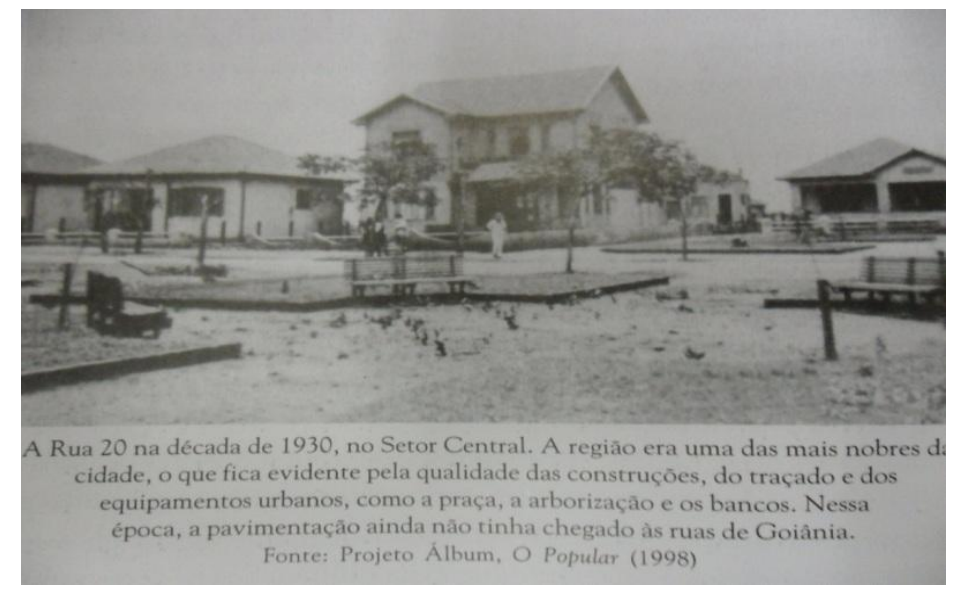

Figura 18. Aspecto da rua 20, na década de 30. Fonte: Daher 2003.

C) As casas planejadas:

De acordo com o relatório de agosto de 1937, enviado ao interventor Pedro Ludovico pelo engenheiro Abelardo Coimbra Bueno, foram construídas ou se encontravam em fase de construção: (a) "casas operárias" (térreas, de dois quartos) no Setor Norte, (b) "casas de funcionários" (térreas, de dois e três quartos) ao norte da avenida Anhanguera, na rua 4; ao sul dessa avenida, estavam em construção (c) as “casas tipo-4Q" (quatro quartos, com dois pavimentos) na rua 7, e (d) as "casas-tipo especial" (personalizadas), na rua 20 (Alvares 1942: 51-62).

É notável que, nas quatro categorias de casas descritas, a hierarquização da classificação se reflete na gradação harmônica dos valores médios de construção, da média de área construída, do grau de personalização, da distribuição espacial das residências em relação ao centro administrativo da cidade e, finalmente, da forma de distribuição dos imóveis a seus ocupantes ${ }^{62}$; resultando na seguinte estratificação:

Ao sul da avenida Anhanguera (Setor Central): os notáveis com suas casas-tipo especiais e com os nomes dos destinatários indicados no relatório, e os altos funcionários com suas casas-tipo 4Q de dois pavimentos.

\footnotetext{
${ }^{62}$ Gonçalves (2002: 83-84), por exemplo, irá afirmar que muitos terrenos foram doados no Bairro Popular (Setor Norte) e que muitos financiamentos de residências para pequenos funcionários públicos foram feitos na rua 4 e no Bairro Popular.
} 


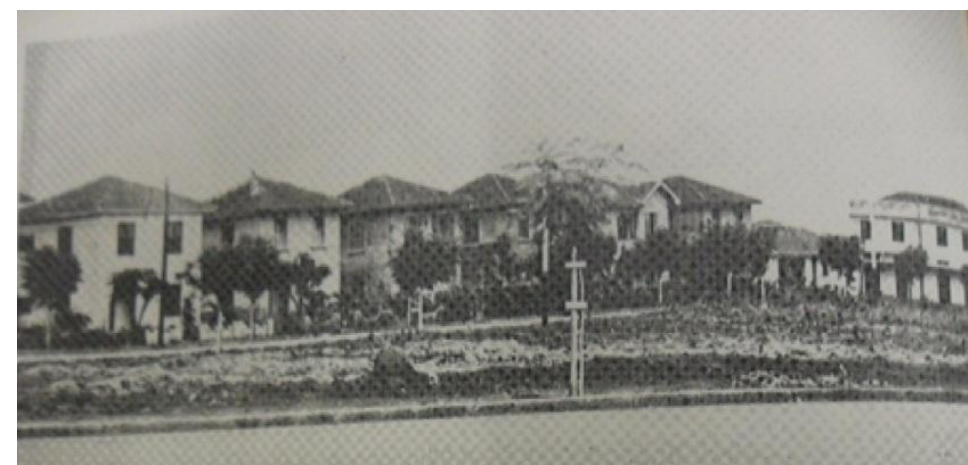

Figura 19. Casas-tipo 4Q na rua 7, em foto da década de 40. Fonte: Daher 2003.

Ao norte da avenida Anhanguera (Setor Central), ficariam os "funcionários" com suas casas de padrão médio, térreas, as casas-tipo $2 \mathrm{Q}$ e $3 \mathrm{Q}$.

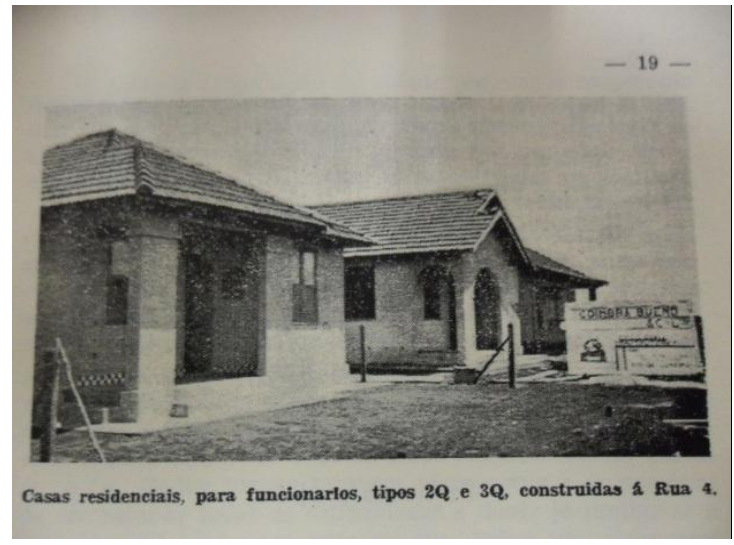

Figura 20. Residências para “funcionários”. Fonte: Alvares 1942

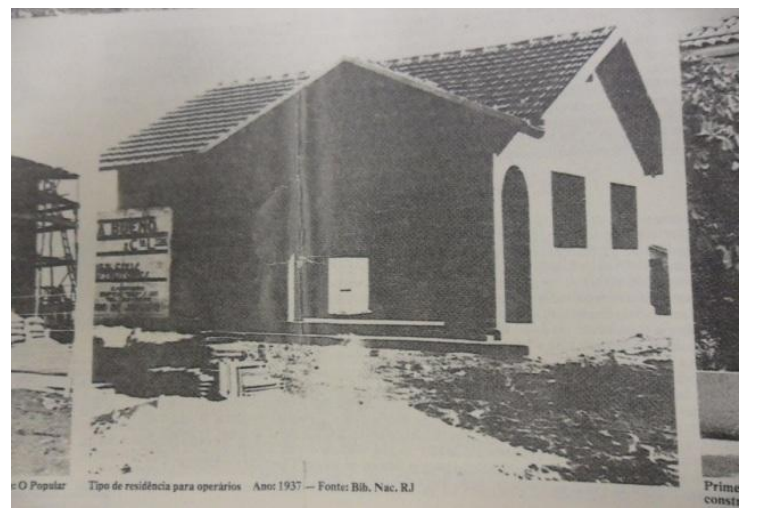

Figura 21. Residência para “operários”. Fonte: Daher 2003

No Setor Norte, foram construídas as residências dos "operários", as mais simples e de construção mais barata dentre aquelas consideradas modernas e, portanto, regulares, permitidas, legais. 


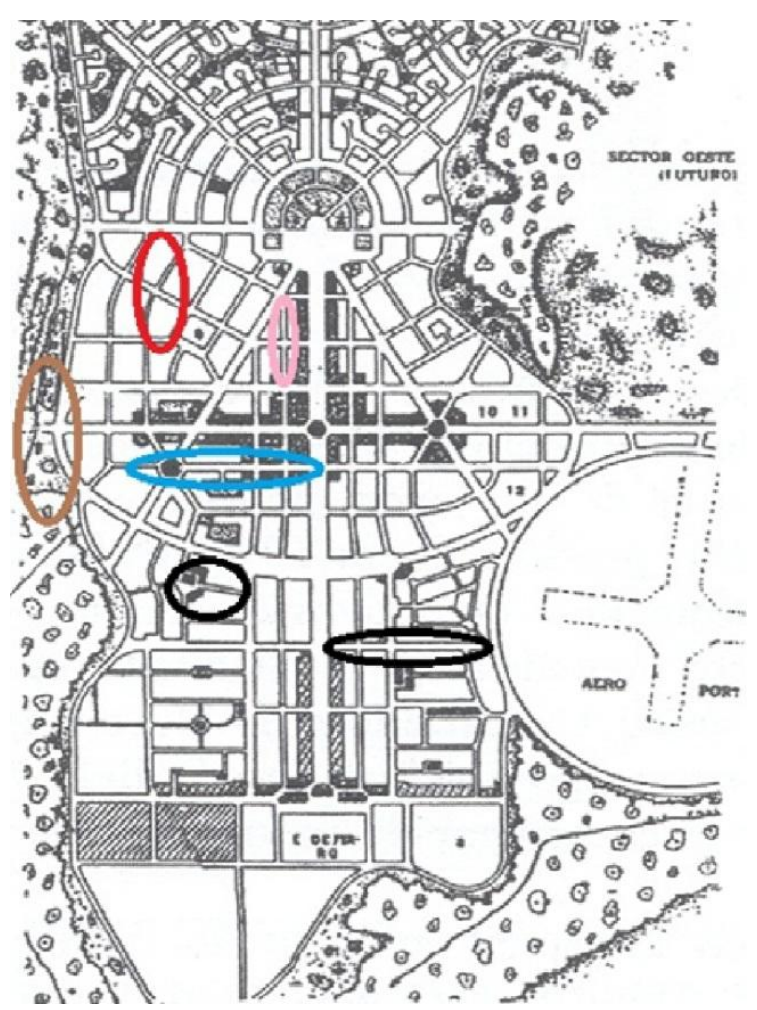

Figura 22. Localização das primeiras casas construídas em Goiânia: em marrom, a localização do acampamento da construção, local de barracões, casebres e choupanas improvisadas. Em vermelho, as casas modelo da rua 20, personalizadas e de maior custo de construção. Em rosa, as casas de funcionários importantes da rua 7, de dois andares. Em azul, as "casas de funcionários" da rua 4. Em preto, as "casas operárias" das ruas 55 e 71. Trata-se de uma estratificação surpreendentemente "harmônica": Na parte baixa os operários, no meio os funcionários e no alto a elite. Marginais à parte.

D) As primeiras edificações não residenciais:

Gonçalves afirma que as primeiras edificações comerciais de Goiânia foram construídas na avenida Anhanguera, ainda na década de 30. Muitas delas foram ocupadas por firmas antes instaladas na vizinha Campinas, antiga sede de município que, com a criação de Goiânia, se tornou uma cidade-satélite. Alguns edifícios comerciais particulares construídos na década de trinta abrigaram funções públicas, como o que foi alugado aos Correios e Telégrafos, ou como outro edifício, na esquina das avenidas Anhanguera e Araguaia, que abrigou a Prefeitura Municipal (Gonçalves 2002: 85). 


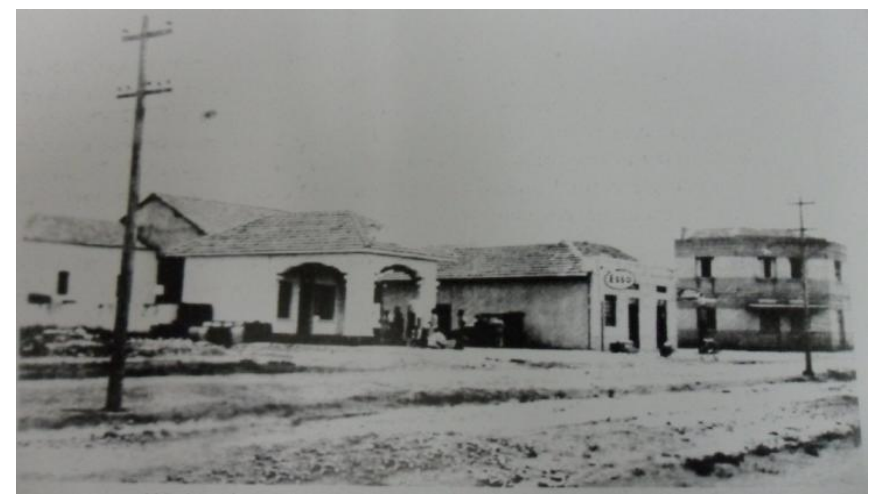

Figura 23. Edifícios comerciais na avenida Anhanguera no final da década de 30. O edifício do Café Central, no cruzamento da avenida Anhanguera com a rua 7, é o que aparece no canto direito da imagem. Fonte: SEPLAM

Quanto aos primeiros edifícios não residenciais da cidade e construídos por iniciativa do Estado, há os seguintes exemplos: O palácio do governo, na Praça Cívica, cuja construção se inicia em 1934, o edifício da Secretaria Geral do Estado e o Grande Hotel, cujas obras se iniciam em 1935. Esses três edifícios estavam concluídos em 1937. Outros edifícios públicos situados na Praça Cívica e o Ginásio do Estado (depois Liceu) estavam ainda em construção no final desse ano. Em 1940 foi inaugurado o Automóvel Clube, em área próxima ao terreno onde se construía o Teatro Goiânia, na avenida Anhanguera. Próximo dali, a Santa Casa de Misericórdia ainda estava em obras em $1940^{63}$ (Gonçalves 2002: 85-86).

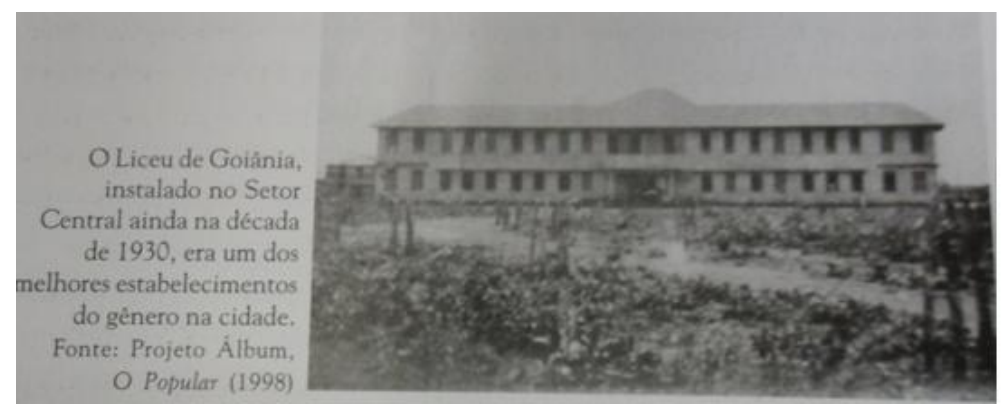

63 “O primeiro hotel, já tombado pelo patrimônio histórico, foi o Grande Hotel, localizado na esquina da rua 3 com avenida Goiás. O primeiro posto de gasolina e oficina mecânica era de propriedade de Pila de Baiochi e foi construído onde hoje está o Edifício Baiochi (rua 7, esq. com Av. Anhanguera, de frente ao Café Central). [...] O Banco Hipotecário de Minas Gerais foi a primeira agência bancária, localizando-se a princípio em Campinas, e, depois transferido para Goiânia. [...] A primeira biblioteca foi fundada através de um baile, onde rapazes tinham de oferecer um livro para entrar. [...] O primeiro registro de nascimento foi de Goiany Segismundo Roriz, filho de Germano Roriz e América do Sul Roriz, nascido em 5 de abril de 1935, registrado no cartório de João dos Santos. A primeira empresa aérea a efetuar ligação com a nova capital foi a VASP, com o avião Dragon Rapid, um biplano de fabricação inglesa, que pousou em Goiânia no dia 8 de agosto de 1938. Dentre os seus passageiros, encontravam-se os ilustres escritores Monteiro Lobato e Mário Donato". (Goiânia 60 anos, Suplemento Especial, Jornal O Popular, 1993: 2627. Apud Oliveira e Silva 2006: 146). 
Figura 24. O Liceu. Fonte: Daher 2003

Certas funções públicas não foram situadas no Setor Central, que, como foi colocado acima, estava destinado às moradias dos notáveis e dos "funcionários". No Setor Norte, a Escola de Aprendizes e Artífices e a Penitenciária estavam em construção no ano de 1939 (idem). Isso quer dizer que os edifícios públicos também foram hierarquizados de acordo com os critérios do primeiro plano diretor.

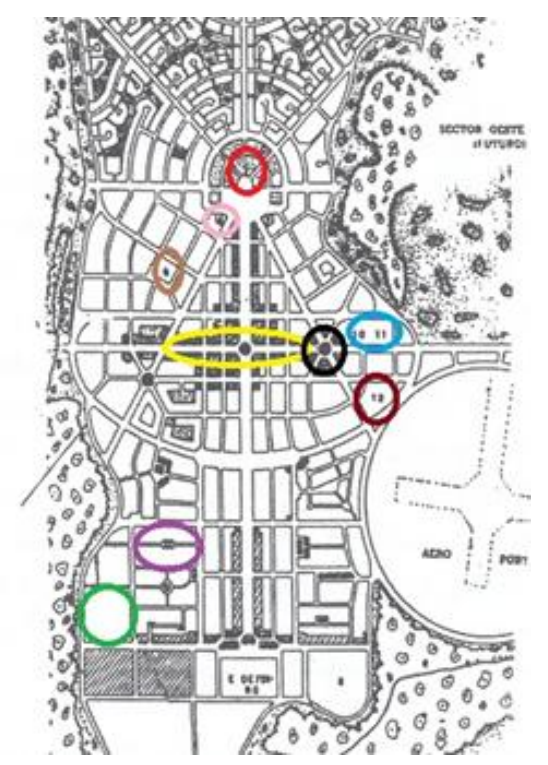

Figura 25. Resumo das primeiras edificações não residenciais, até 1940. Em vermelho, o Palácio das Esmeraldas, sede do governo estadual; em rosa, a Secretaria Geral do Estado; em marrom, o Ginásio do Estado, atual Liceu; em amarelo, a faixa da avenida Anhanguera onde foram instalados os primeiros edifícios comerciais; em preto, o Cine-Teatro Goiânia (ainda em construção em 1940); em azul, o Automóvel Clube; em vermelho escuro, a Santa Casa de Misericórdia; em roxo, a Escola de Aprendizes e Artífices e em verde, a Penitenciária. Os dois últimos edifícios foram construídos no Setor Norte, o "Bairro Popular".

\subsubsection{O adensamento nas décadas de quarenta e cinquenta}

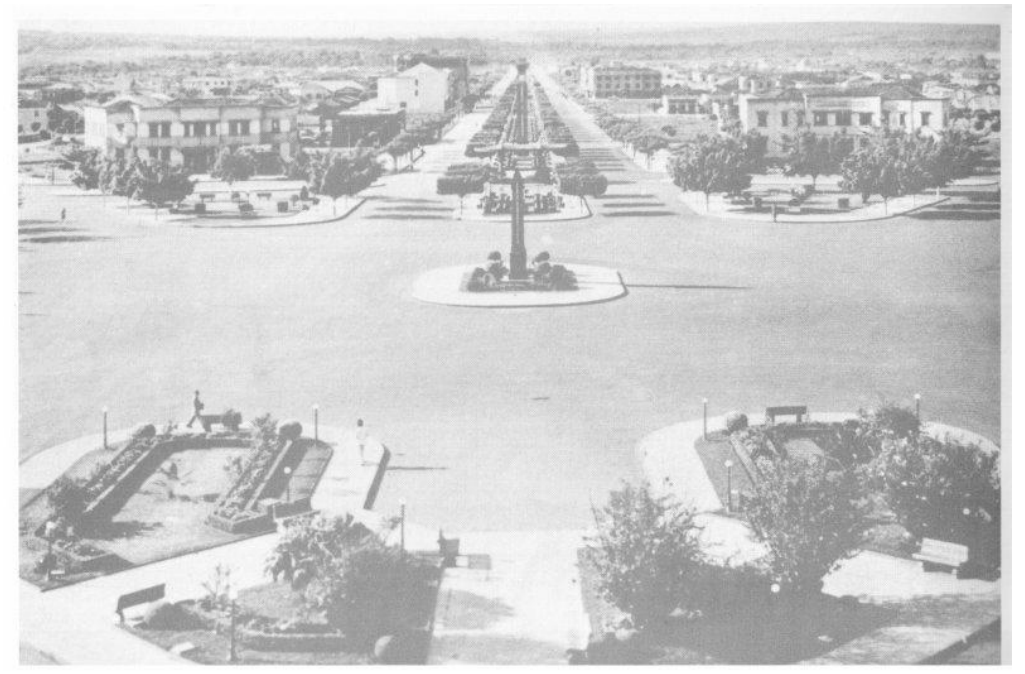


Figura 26. Vista para o norte a partir do terraço do Palácio das Esmeraldas, 1942. Em poucos anos a parte central da cidade passou a apresentar um aspecto menos desolado do que na época da visita de LéviStrauss. Fonte: SEPLAM

A) As residências de alto padrão:

De acordo com Gonçalves (2002: 90-97), alguns arquitetos, engenheiros e desenhistas envolvidos com o projeto da cidade atuaram também para particulares, projetando e construindo residências e edifícios comerciais em Goiânia e fachadas para "maquiar" edifícios comerciais pré-modernos na cidade-satélite de Campinas. Essas residências particulares projetadas pelos arquitetos eram, na maioria das vezes, destinadas a "fazendeiros e doutores". Os arquitetos e engenheiros sustentavam um discurso "moderno", sempre "em sintonia com o que se passava no Rio e em São Paulo" (Gonçalves 2002: 91). Essas residências possuíam geralmente dois andares e se situavam, em sua grande maioria, na área onde as esperaríamos encontrar: ao sul da avenida Anhanguera e próximos da Praça Cívica.

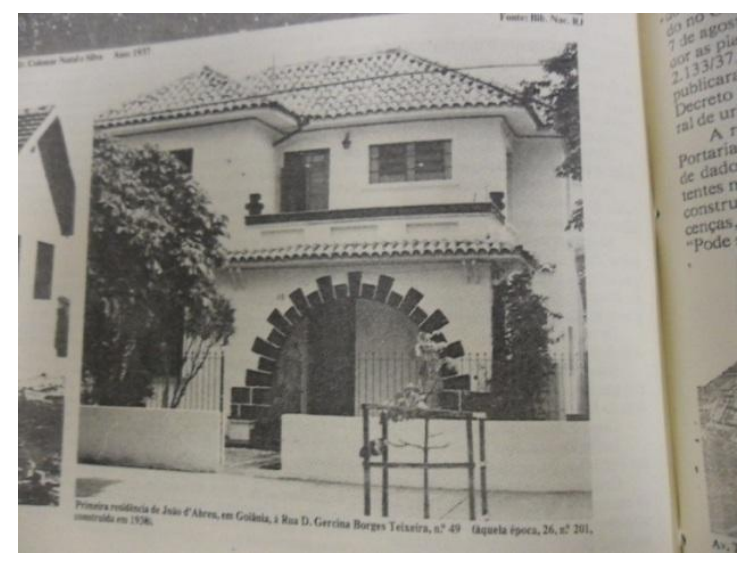

Figura 27. O sobrado acima se assemelha às aos sobrados descritos e fotografados por Mahler e Silva (2007), denominados "neocoloniais". Sua localização é "estratégica": entre a Praça Cívica e o Bosque dos Buritis, na confluência dos setores Central, Sul e Oeste. Construído em 1938. Fonte: Daher 2003.

De acordo com Mahler e Silva (2007: 112), esses engenheiros-arquitetos se serviam de "cartilhas de estilo", oferecendo mostruários aos proprietários "com um variado cardápio de opções decorativas”. Mais uma vez, e mesmo já havendo na cidade as "casas modelo", o que se oferecia era "os exemplos que figuravam nas grandes cidades brasileiras". Mahler e Silva citam e localizam as seguintes residências:

- No estilo neocolonial (em vigor nos anos 30-50): Um sobrado na avenida Araguaia número 808; Um sobrado na rua 29, número 190.

- No estilo normando (em vigor nos anos 40-50): Um sobrado na avenida Tocantins número 63; Um sobrado na rua 20, número 220. 
- No estilo eclético (em vigor nos anos 40-50): Uma casa térrea na rua 20, número 268.

- No estilo Art déco (em vigor nos anos 30-50): Um sobrado na rua Dona Gercina Borges Teixeira, esquina com a rua 25. Trata-se da residência definitiva de Pedro Ludovico em Goiânia. Terminada em 1937, essa casa abrigou por algum tempo a sede da Prefeitura Municipal, após esta deixar o imóvel particular que ocupava anteriormente, sendo depois habitada pelo fundador da cidade (Gonçalves 2002: $87)$.

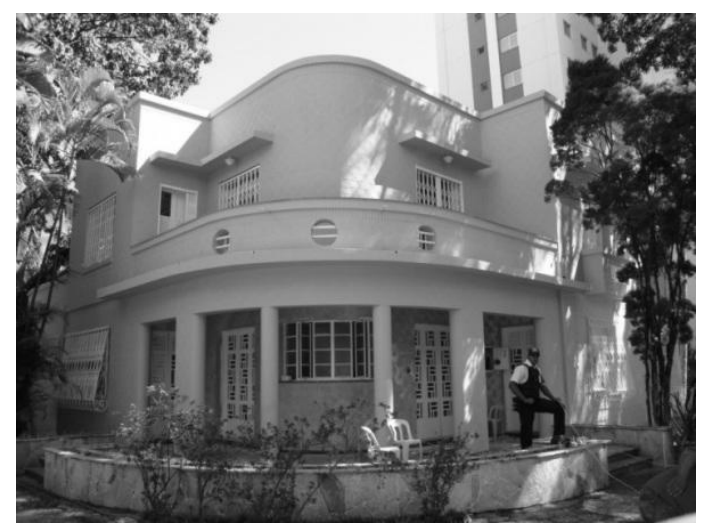

Figura 28. A residência em que Pedro Ludovico passou a residir após deixar a rua 20, situada entre a Praça Cívica e o Bosque dos Buritis. Atualmente tombada pelo IPHAN e convertida em museu. Foto do autor.

Oliveira e Silva (2006: 184) cita "um belo sobrado" no estilo art déco, na avenida Tocantins, esquina com a rua 2 , e um sobrado no estilo normando, na avenida Tocantins, esquina com a rua 1 , ambos já demolidos.

Por fim, o dossiê de 2004 do IPHAN, acerca do patrimônio histórico de Goiás, indica três sobrados não citados anteriormente, que foram tombados entre 1999 e 2001, como parte do "patrimônio art déco" de Goiânia. Um desses sobrados foi residência do primeiro prefeito da cidade, Venerando de Freitas, situado na rua 1, número 2, construído na década de 30 e que está atualmente alugado para fins comerciais; o segundo sobrado é a antiga residência de um conhecido fazendeiro e político local, Altamiro Moura Pacheco (não datada), e abriga atualmente um centro cultural; o terceiro sobrado se encontra na avenida Tocantins, número 675, e é datado do final da década de 40, abrigando atualmente a sede local do IBGE. O dossiê do IPHAN classifica esse último imóvel, situado na região dos "funcionários", como exemplo de uma "arquitetura simples e comum", "de acordo com os padrões vigentes na época" (Manso e Unes: 2004). 


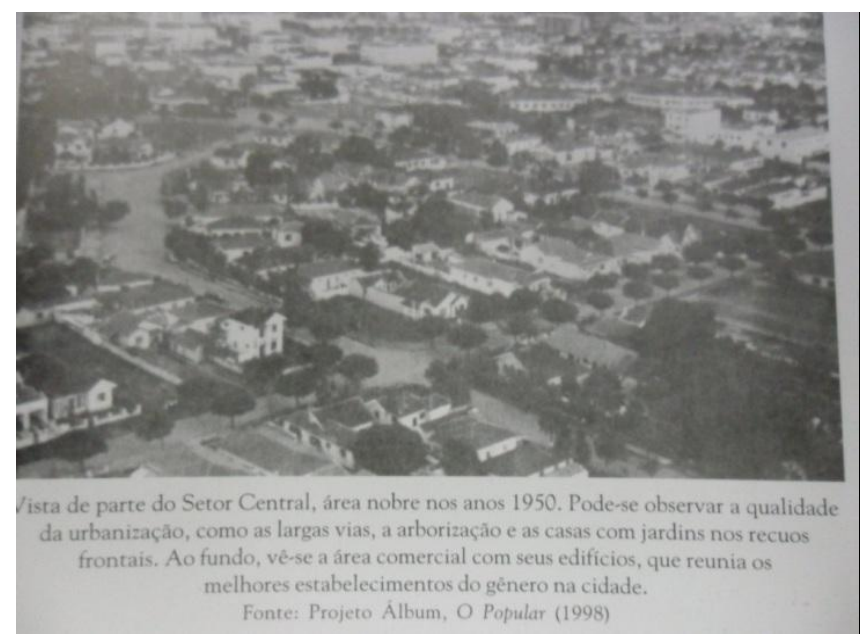

Figura 29. A rua 20 em primeiro plano, na década de 50. Fonte: Daher 2003

Todas as residências indicadas acima e citadas por Daher (2003), Oliveira e Silva (2006), Mahler e Silva (2007) e pelo dossiê do IPHAN de 2004 serão consideradas residências de alto padrão ${ }^{64}$, pois elas correspondiam a estilos em voga no momento que foram construídas e foram projetadas por profissionais reconhecidos, para atender clientes de alta posição social. Além disso, quase todas ocupavam áreas próximas à Praça cívica e contavam com amplos espaços construídos e, com apenas uma exceção, com dois pavimentos.

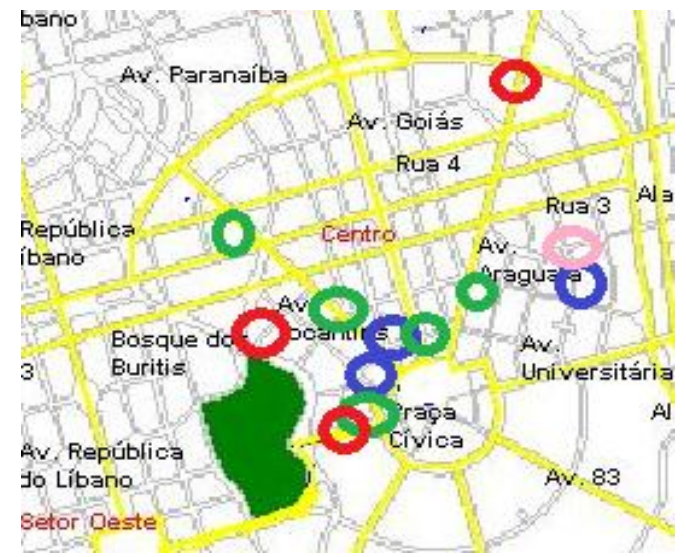

Figura 30. Mapa das residências nos estilos art déco, neocolonial, normando e eclético localizadas por Daher (2003), por Mahler e Silva (2007), por Oliveira e Silva (2006) e pelo relatório do IPHAN de 2004. Em verde, as residências "no estilo art déco", incluindo a residência de Pedro Ludovico, entre a Praça Cívica e o Bosque dos Buritis, e aquelas citadas pelo relatório de 2004 do IPHAN como tombadas e parte do patrimônio art déco; em vermelho, as residências neocoloniais; em azul, as residências no estilo normando; e em rosa, a residência no estilo eclético. Apenas duas dessas residências estão situadas ao norte da avenida Anhanguera (uma delas descrita como "simples e comum"). As outras estão situadas na faixa residencial pioneira de alto padrão da rua 20 ou na área entre a Praça Cívica e o Bosque dos Buritis. O mapa está disposto de maneira normal, com o norte voltado para cima.

\footnotetext{
${ }^{64}$ Exceto o último dos três sobrados citados pelo relatório do IPHAN, considerado de padrão médio.
} 
B) Os edifícios comerciais no estilo art déco e outras edificações e áreas comerciais:

Depoimentos coletados por pesquisadores indicam as atividades comerciais de alto padrão na cidade de Goiânia em suas primeiras décadas. O pai das depoentes Edith Amaral Ferreira e Adenir Amaral de Castro, Augusto Amaral Muniz, que residia na rua 20 durante a década de 40, era proprietário da Casa Confiança, "uma das casas mais chics de Goiânia", em um edifício no estilo art déco próximo à avenida Anhanguera. "Papai tinha tudo ali. Era louça, calçado, tecido, coisas de cozinha. Foi a primeira loja, primeira vez em Goiânia que se mostrou coisa de natal”. E ainda: “Toda aquela gente rica, todos compravam de caderneta. Chegava fim de mês iam lá acertar" (Santana, Bonetti e Macêdo 2007: 174).

Como exemplo de um edifício comercial construído de acordo com o estilo art déco, Mahler e Silva fotografaram um imóvel situado na rua $20 \mathrm{com}$ a avenida Anhanguera. Após uma análise de suas formas, os autores afirmam que "é possível localizar ainda muitos edifícios de dois e três pavimentos em estilo art déco nas pontas de quadras (esquinas). Alguns desses edifícios eram de uso misto: o térreo destinado ao uso comercial e o primeiro pavimento ao uso residencial" (Mahler e Silva 2007: 121). Oliveira e Silva (2006: 184) se refere a dois importantes edifícios comerciais de propriedade particular construídos no estilo art déco. Em um deles, na avenida Araguaia, esquina com a rua 3 , funcionou a primeira agência dos correios, e em outro edifício, já demolido, no cruzamento da avenida Araguaia com a avenida Anhanguera, funcionava a primeira sede da Prefeitura Municipal (Gonçalves 2002: 86). Outros edifícios comerciais referidos por Oliveira e Silva são: (a) o edifício do jornal O Popular, situado na avenida Goiás, quadra 7; (b) um edifício de três andares na avenida Anhanguera, quadra 53; e (c) um edifício na rua 6, esquina com a avenida Anhanguera. Esses edifícios mantinham o mesmo padrão arquitetônico das construções públicas e, nesse quesito, por apresentarem o padrão ideal da época em Goiânia, se contrastam com os edifícios comerciais "fachadistas” de Campinas citados por Gonçalves (2002).

Gonçalves denomina como "fachadismo" a prática de aplicar novos arranjos de fachadas a edifícios cuja forma de construção permanece sem grandes alterações. Tratase assim, de uma "modernidade da aparência" (2002: 109). Geralmente eram construções comerciais de alvenaria cujo telhado de quatro águas era ocultado por "platibandas e elementos decorativos na fachada". Essas fachadas acompanham o estilo 
art déco dos edifícios da cidade principal e "mudaram a aparência" da principal avenida de Campinas, a 24 de Outubro. Esses edifícios muitas vezes eram de uso misto, residencial e comercial. Muitas residências em Campinas também seguiam essa tendência, disfarçando o telhado de quatro águas com frontões e platibandas (Gonçalves 2002: 111). As edificações "fachadistas" de Campinas são apresentadas aqui como exemplos de edificações comerciais de padrão médio.

Campinas foi o local de concentração inicial dos comerciantes árabes que imigraram para Goiânia, de acordo com Nunes (2007: 206). "A atual Avenida 24 de Outubro se tornou a via do comércio dos imigrantes árabes e de seus descendentes". "É nesse setor que os árabes instalaram suas lojas e suas pequenas indústrias, destacando-se um grande número de cerealistas e máquinas de beneficiamento de cereais”. Quanto ao varejo: "Eram lojas especializadas em roupas, calçados e em miudezas oferecidas pelos bazares tradicionais". Nas páginas 208 e 209, a autora sintetiza:

\footnotetext{
Na verdade, por ocasião da fundação de Goiânia e ao longo dos anos 50 e 60, os sírios e libaneses consolidaram e ampliaram seus negócios, monopolizando praticamente o comércio varejista de tecidos e de produtos ligados ao setor da construção civil, ocupando a posição mais importante no comércio atacadista. A colônia árabe em Goiás construiu um setor totalmente integrado verticalmente, em que industriais e atacadistas supriam as necessidades de uma rede ampla de varejistas e comerciantes ambulantes pertencentes à mesma etnia.
}

Mas os camponeses da zona rural do município podiam se dirigir a outros locais de comércio, como no depoimento de um casal que residiu na Fazenda Bom Sucesso, a leste da capital, na década de 40: "Só vinha a cavalo. (...) O comércio para comprar as coisas era Goiânia, e o lugar mais próximo era Goiânia. A ida a Bela Vista era muito longe e não se encontrava quase nada que precisava. Em Goiânia se encontrava tudo. O comércio principal criado era no [bairro marginal] Botafogo. Ali era o primeiro bairro. Depois foi criado Vila Nova [sobre parte do mesmo bairro, em um processo de legalização da área] e aí foi criando outros bairros. A gente vinha para comprar calçado, comprar roupas, não tinha quase roupa feita, a gente comprava tecido para fazer as roupas. O que se comprava de mantimento era sal, café... Agora, arroz, feijão, essas outras coisas, a carne, tudo a gente tinha lá na fazenda" (Santana, Bonetti e Macêdo 2007: 176-177). O comércio do Bairro Botafogo pode ser considerado de padrão baixo.

C) Os hotéis construídos a seguir ao Grande Hotel e a hospedagem de baixo padrão em Goiânia: 
Oliveira e Silva (2006) indica os seguintes hotéis instalados em edifícios no estilo art déco e surgidos na década de 50: (a) Lord Hotel (ao lado do edifício do Café Central), (b) o Marmo Hotel (sem localização) e (c) o Goiânia Palace Hotel (na avenida Anhanguera número 125). Por outro lado, nas margens do Córrego Botafogo, havia a pensão da Dona Murca, (Lima Filho 2007: 249). No extremo oposto do "padrão de hospedagem" das primeiras décadas de Goiânia, estava a famosa árvore Moreira, que, de acordo com depoimento coletado por Santana, Bonetti e Macêdo (2007: 166), "acolhia todo mundo que vinha, para as pessoas que chegavam e ficavam lá em baixo até fazer seus ranchinhos, suas casinhas barreadas para trazer a família".

D) A sociabilidade:

Oliveira (1999) e Oliveira e Silva (2006), apresentam alguns aspectos da sociabilidade urbana dos primeiros tempos da cidade.

Futebol: havia dois times importantes de futebol nas primeiras décadas, o Atlético Clube Goianiense, fundado em 1937 em Campinas, e o Goiânia Esporte Clube, fundado em 1938, na cidade principal. "o Goiânia, como era chamado pela população, era um time de elite, ligado ao grupo aglutinado em torno de Pedro Ludovico" (Oliveira 1999: 42). Já o Atlético “era considerado um time de massa” (idem).

Antagonismo entre jovens da cidade principal e da cidade-satélite: De acordo com Oliveira, os habitantes de Campinas, "especificamente seus elementos mais jovens do sexo masculino, preocupados com a concorrência dos jovens goianienses sobre a população do sexo oposto de Campinas", denominavam-nos "almofadinhas e alinhadinhos, termos que indicam uma crítica a um estilo de vida mais preocupado com a estética do que com o trabalho". (Oliveira 1999: 44). "Em contrapartida, os habitantes de Goiânia referiam-se a Campinas, utilizando o termo chacrinha, indicando pejorativamente as origens rurais do agora bairro" (idem).

Bares: Oliveira cita um bar situado na avenida Goiás (ao sul da avenida Anhanguera) a Brasserie, "um dos poucos locais acessíveis a senhoras e crianças, pois durante o dia funcionava como sorveteria" (Oliveira 1999: 55). No Bairro Botafogo, "havia o Céu Azul, ponto de encontro de operários". Oliveira e Silva (2006:142), cita, como bares frequentados pela elite, o Adis-Abeba "que teve a primeira mesa de bilhar da cidade", na avenida Goiás sem numeração; o Bar Serra Dourada, "um bar bastante luxuoso para a época", na avenida Goiás, esquina com a rua 3; e o Café Central, na 
Avenida Anhanguera com a rua 7, fundado em 1955 e "muito frequentado por políticos".

Lagos e córregos: de acordo com Oliveira (1999) e citado também por outros autores, o Lago das Rosas, com sua piscina pública, era um local "que reunia jovens de diversas camadas sociais e um dos principais pontos de lazer da juventude da época; porém, os costumeiros casos de afogamentos e a existência de uma escandalosa boate (chamada Lago das Rosas) tornou-o, a partir de meados dos anos 50, um local rejeitado pela classe média" (Oliveira 1999: 55). A depoente Elisa de Macedo Alves de Castro relembra o uso do lago: "Eu ia com minha tia, que morava na rua 20. Ela gostava demais de nadar! Ela botava aqueles maiozão de velha! Levava a turma toda! Nadava no Lago das Rosas. Às vezes levava a gente para fazer piquenique” (Santana, Bonetti e Macêdo 2007: 180).

O Bosque dos Buritis era local de aventuras infantis, como relembra o fazendeiro e político Otaviano Roriz Soares de Carvalho: “A gente ia lá pegar taquara pra fazer pipa, fazer raia. Tinha... mais no meio do bosque tinha um lugar que dava para a gente tomar banho... Mas meu pai e minha mãe não deixavam. A gente ia lá escondido" (Santana, Bonetti e Macêdo 2007: 180).

No Córrego Botafogo, contemplação e trabalho se misturam no depoimento da escritora Dona Virgínia Pereira Mendes:

\begin{abstract}
A gente contemplava e até parava pra ver, aquele tanto de mulheres lavando roupas no Córrego Botafogo. A água era muito limpa, elas colocavam as roupas para secar em cima daquele capim verde e baixinho em torno do córrego. A gente ficava contemplando a beleza daquela verdadeira colcha de retalhos que se formava com roupas coloridas em contraste com aquele capim verdinho. Lembro-me de quando achava linda aquela visão, além do frescor da água, e depois dos gostosos banhos naquela água tão limpinha (Santana, Bonetti e Macêdo 2007: 179).
\end{abstract}

O footing e os imóveis associados: a prática, comum em várias cidades brasileiras, teria se iniciado em Goiânia na década de 40 (Oliveira 1999: 55), mas ela já estava prevista pelos próprios criadores da cidade, para ocorrer na avenida Goiás, nas imediações da Praça Cívica. O footing, em sua forma tradicional associada ao cinema vespertino aos domingos, indica hábitos de sociabilidade que ocorreram também em Campinas (idem: 56). Mas, seja em Campinas ou em Goiânia, a prática se realizou sempre em áreas centrais e valorizadas, e isso vale também para o posterior "footing motorizado" da Praça Tamandaré e da avenida Ricardo Paranhos ${ }^{65}$.

\footnotetext{
${ }^{65}$ O footing, para Oliveira, "fornece informações valiosas para estudar a mudança cultural em Goiânia,
} pois sua prática variava no espaço de época a época, denunciando uma valorização ou desvalorização de 
Com a inauguração do Cine-Teatro Goiânia em 1942, o footing "passou a ser realizado entre o espaço que ia desse prédio até a avenida Anhanguera". A partir de 1945 ele era praticado na avenida Goiás em frente ao Grande Hotel, onde se situava a “movimentada sorveteria” Brasserie (Oliveira 1999: 56-57). No início da década de 50, com a urbanização da Praça Cívica, que passou a contar com fontes luminosas, o "vai e vem" para lá se transferiu. No final dos anos 50, o footing se deslocou para a rua 8 , nas proximidades do Bar Acapulco, do Lanche Americano e do cine Casablanca. No início dos anos 60, o footing "perde a sua importância como forma de lazer na cidade" (idem: $57)$.

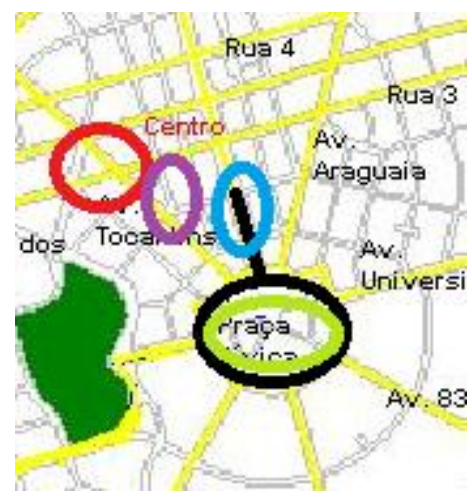

Figura 31. O footing em Goiânia de acordo com Oliveira (1999). Em preto, o local da prática do footing previsto por Attilio Corrêa Lima em 1933. Em vermelho, o footing na primeira metade da década de 40, diante do Cine Teatro Goiânia. Em azul, o footing na segunda metade da década de 40, diante do Grande Hotel. Em verde o footing na Praça Cívica, após sua urbanização, no início da década de 50. Em roxo, o footing na rua 8 , no final da década de 50, período em que a rua apresentou uma grande concentração de bares. O footing sempre foi praticado na área que é considerada por esta pesquisa como o primeiro distrito de alto padrão de Goiânia.

Carnaval: de acordo com o Oliveira (1999: 57), os bailes "elitistas" de carnaval se realizavam no Automóvel Clube. O Automóvel Clube, que depois veio a se chamar Jóquei Clube, tinha suas ações como "símbolo de status social" (Oliveira e Silva, 2006: 141), e, nesse local, “a população de Campinas era impedida de entrar", o que levou os moradores da antiga sede municipal a criarem seu próprio clube, o Goiânia Tênis Clube, na década de 50 (idem). No depoimento de Edith Amaral Ferreira:

Antes de me casar, até brinquei muito no Jóquei, no carnaval. Estava o Pedro Ludovico, aquela coisa toda, até brinquei com o Pedro ali. A gente conhecia todo mundo, sabe? Você podia ficar bem à vontade, você conhecia todo mundo. Hoje eu não conheço mais ninguém. Antigamente

certas partes da cidade" (Oliveira 1999: 56). A Praça Tamandaré foi palco de "rachas" (disputas de velocidade com automóveis e motocicletas) e de prática de sociabilidade juvenil nas décadas de 70 e 80 . No final da década de 80, o "footing motorizado" passou a ser praticado na avenida Ricardo Paranhos, no Setor Marista. 
era gostoso, a gente saía cumprimentando todo mundo, a gente conhecia as festinhas no Jóquei, era o único lugar de festa que tinha era o Jóquei (Santana, Bonetti e Macêdo 2007: 186).

Réveillon: as famílias abastadas da cidade organizavam, desde 1936, um baile de ano-novo no Palácio das Esmeraldas, onde se exigia o uso de smoking (Oliveira 1999: 57).

O edifício do Grande Hotel: as calçadas do Grande Hotel foram locais de footing e seu interior era um espaço compartilhado pela elite. De acordo com depoimento de Elisa de Machado Alves de Castro, eram “muito boas as festas lá". "Os melhores casamentos, os meus quinze anos foram comemorados, foram festejados no Grande Hotel”. Já para aqueles que não faziam parte da elite: "Entrei muitas vezes lá, para consertar fechadura, coisas assim”. "A gente não tinha relação. Porque naquele traje que a gente tinha de carpinteiro e marceneiro, pessoas importantes que vinham não tinham diálogo nenhum com a gente" (Santana, Bonetti e Macêdo 2007: 170).

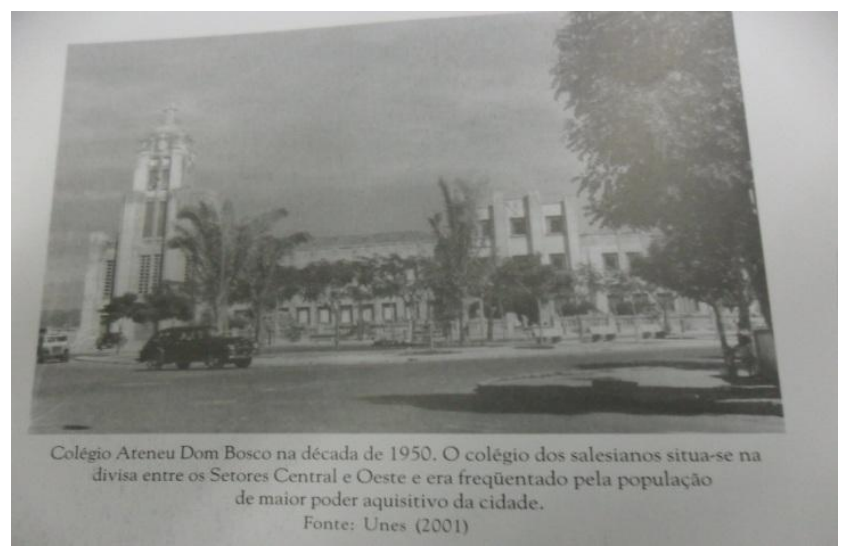

Figura 32. O colégio Ateneu Dom Bosco, primeira edificação do Setor Oeste e o segundo colégio de alto padrão de Goiânia, em seguida ao Liceu.

Colégios: depois da construção do Liceu, surgiram outras unidades de educação associadas à elite pelos autores pesquisados: A Faculdade de Direito, transferida da antiga capital, se instalou na rua 20 em 1937, ocupando a casa-tipo especial que serviu de residência a Pedro Ludovico. "Estava assegurada assim a formação da elite intelectual" (Lima Filho 2007: 251). A Escola Normal, também transferida da Cidade de Goiás, foi igualmente instalada na rua 20, "após o Palácio do Governo e outras repartições se mudarem para a Praça Cívica” (idem). Em 1942, foi fundado o colégio católico Ateneu Dom Bosco, a primeira edificação do Setor Oeste (Gonçalves 2002: 128), que só viria a ser arruado no início da década de 50 (idem: 118). 
A partir de sua inauguração, o Ateneu, situado ao lado do Bosque dos Buritis, veio a ser um colégio “destinado às elites” (Daher 2003: 273).

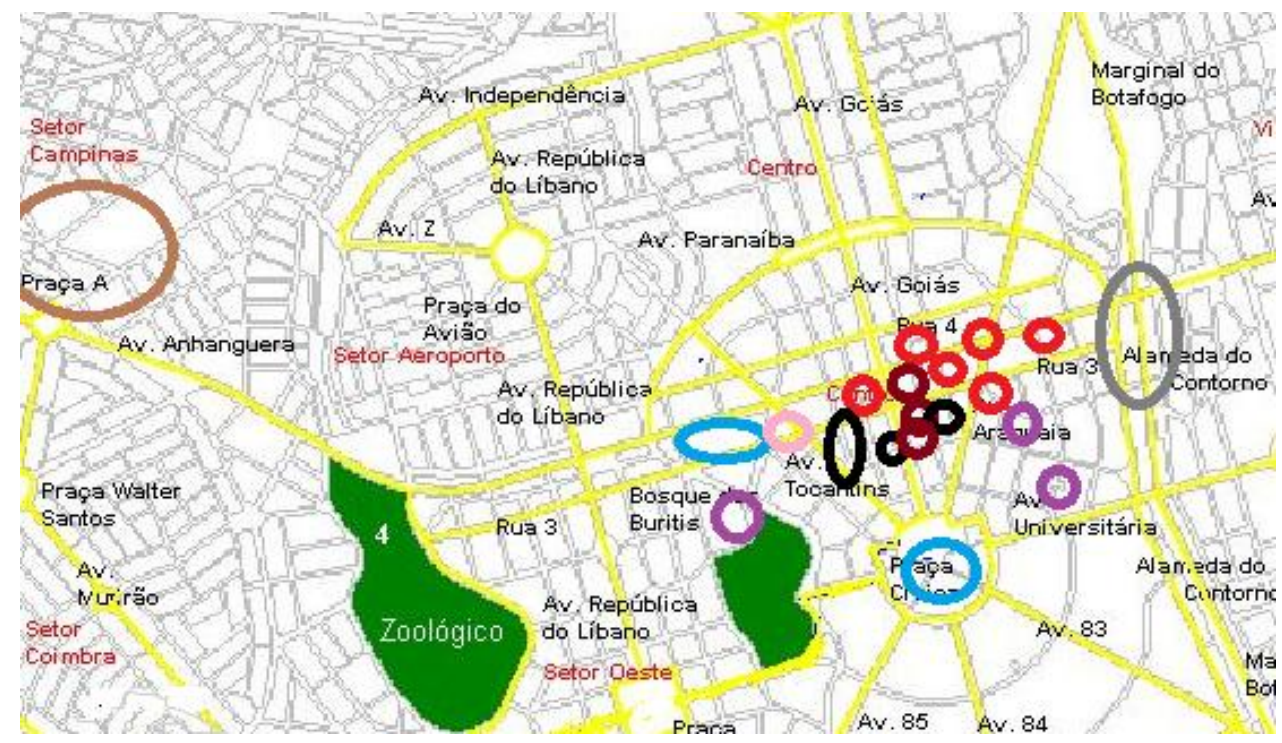

Figura 33. Resumo do comércio e da sociabilidade da elite nas primeiras décadas de Goiânia, conforme os autores pesquisados. Em vermelho, edifícios comerciais construídos no estilo art déco. Em vermelho escuro, os hotéis construídos no estilo art déco (incluindo o Grande Hotel). Em preto, os bares e cafés de alto padrão (incluindo a concentração de bares, sorveterias e lanchonetes da rua 8, que se forma na década de 50). Em rosa, o Cine Teatro Goiânia, inaugurado em 1942. Em roxo, os locais de educação de alto padrão: o Liceu, próximo à rua 20, a Faculdade de Direito na rua 20 e o Ateneu Dom Bosco junto ao Bosque dos Buritis. Em azul, encerrando o conjunto de usos de alto padrão, estão os locais dos bailes "elitistas", no Palácio das Esmeraldas e No Jóquei Clube (inicialmente Automóvel Clube). Em marrom, está o distrito comercial de Campinas, local de concentração de imigrantes sírios e libaneses, com indústrias cerealistas, atacado, varejo e a arquitetura "fachadista" (Notar que o mapa de fundo utilizado é recente e mostra a Campinas atual, como um bairro de Goiânia. Campinas na época não era conturbada com Goiânia, havendo um aeroporto entre as duas cidades, no local onde o mapa utilizado indica o bairro denominado Setor Aeroporto). Em cinza, o núcleo original do Bairro Botafogo, com residências, comércio, pensões, escolas e bares de baixo padrão.

E) Os mapas de memória:

Medeiros (2007) apresenta os resultados de uma pesquisa que coletou, nos anos de 2001 e 2002, narrativas e "mapas de memória" de 26 habitantes de Goiânia, 23 deles com idade superior a 75 anos. De acordo com ou autor, os "mapas de memória" são uma reapropriação dos mapas mentais desenvolvidos por Kevin Linch, que "nos permitem ver uma nova imagem surgida das narrativas", que podem "definir as qualidades físicas relacionadas aos atributos de identidade e estrutura na imagem mental" (Medeiros 2007: 217-218).

O mapa do conhecido escritor e folclorista Gilberto de Mendonça Teles, que mostra "com clareza alguns limites da cidade, que estarão presentes também em vários depoimentos" (Medeiros 2007: 219), apresenta uma curiosa disposição, com o lado oeste voltado para cima, sendo este o único lado cujos limites não foram traçados pelo 
narrador. Nesse mapa, estão desenhados limites largos a leste e ao norte: a leste o Córrego Botafogo e ao norte a ferrovia e o Rio Meia Ponte. A ferrovia, no caso, é apresentada de um modo que se confunde com um curso d'água. Além dela, ao norte, o narrador situou o Bairro Popular. Ao Sul, uma linha é disposta logo além da Praça Cívica, e lá é situado o Setor Sul. No canto noroeste há um círculo que representa o Lago das Rosas, e além deste, Campinas. O flanco oeste, onde está situado o Setor Oeste, composto de "matas e cerrados", é o único flanco que não limitado com traços. Trata-se justamente do sentido da primeira expansão de residências de alto padrão na cidade de Goiânia, que avançou da rua 20 em direção à Praça Cívica e ao Bosque dos Buritis.

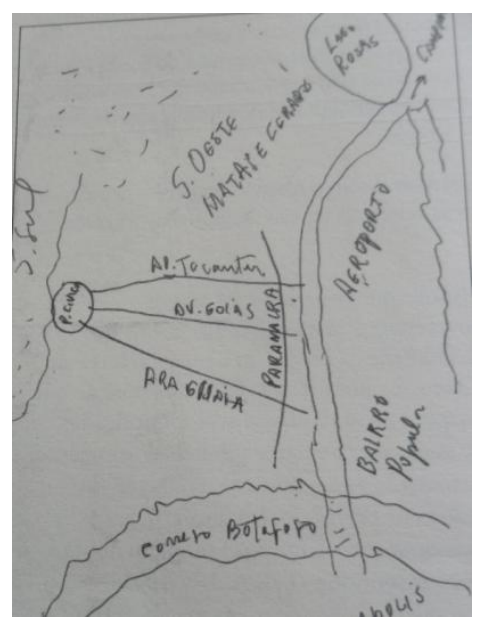

Figura 34. Mapa de memória de Gilberto de Mendonça Teles. Fonte: Medeiros 2007

No mapa de memória de Mauro Borges, filho de Pedro Ludovico e governador de Goiás na década de 60, que representa os arredores da Praça Cívica (Medeiros 2007: 220), são mostrados o que parece ser o contorno da Praça Cívica (parcialmente preenchido), um retângulo que pode representar o Palácio das Esmeraldas e duas vias que partem da praça. Uma das vias talvez seja a rua 90 e a outra talvez seja a rua Dona Gercina, onde um pequeno quadrado representaria a casa de Mauro Borges em sua infância (o sobrado art déco de Pedro Ludovico), diante da alameda dos Buritis, que nesse caso também estaria representada no mapa. Situado além do que me parece ser a alameda dos Buritis, um tracejado parece indicar o Bosque dos Buritis, local de caçadas 
de Mauro Borges quando criança, criada "no entorno da Praça Cívica" (idem: 219$220)^{66}$.

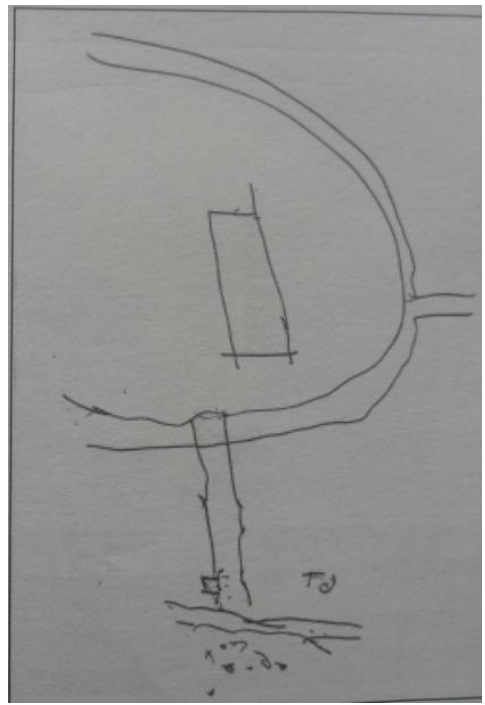

Figura 35. Mapa de memória de Mauro Borges. Fonte: Medeiros 2007

O mapa de memória do escritor e político José Sêneca Lobo mostra a Praça Cívica no topo da figura, com o lado sul voltado para cima e com as três avenidas que formam o "pé de pato" limitadas ao norte pela Praça do Bandeirante e pela avenida Anhanguera. Abaixo da avenida Anhanguera, ficam marcadas a estação ferroviária e o Bairro Botafogo. A leste, na parte esquerda da figura, está o Córrego Botafogo. Mais uma vez, o flanco sudoeste se encontra aberto (Medeiros 2007: 223).

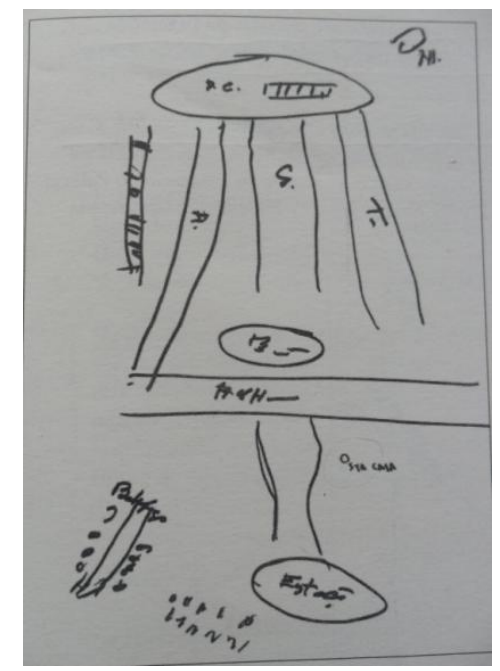

${ }^{66}$ Essa interpretação é altamente hipotética, e se fundamenta na afirmação de Medeiros de que o mapa de memória de Mauro Borges retrata os arredores da Praça Cívica. No desenho aparece algo que se assemelha a uma inscrição com os caracteres "t 2", que nomeiam uma avenida de Goiânia situada relativamente distante da Praça Cívica e do Bosque dos Buritis, embora esta avenida fique na mesma direção proposta pela interpretação, com o lado oeste da cidade voltado para baixo. 
O mapa de memória da escritora Armênia Souza, que se mudou para a cidade em 1936, também está com o lado sul voltado para cima, e mostra uma disposição das vias centrais da cidade conectadas com pontos de referência importantes, de modo que a avenida Anhanguera se apresenta como uma linha vertical que atravessa toda a figura, tendo em seu centro o Grande Hotel (Medeiros 2007: 223).

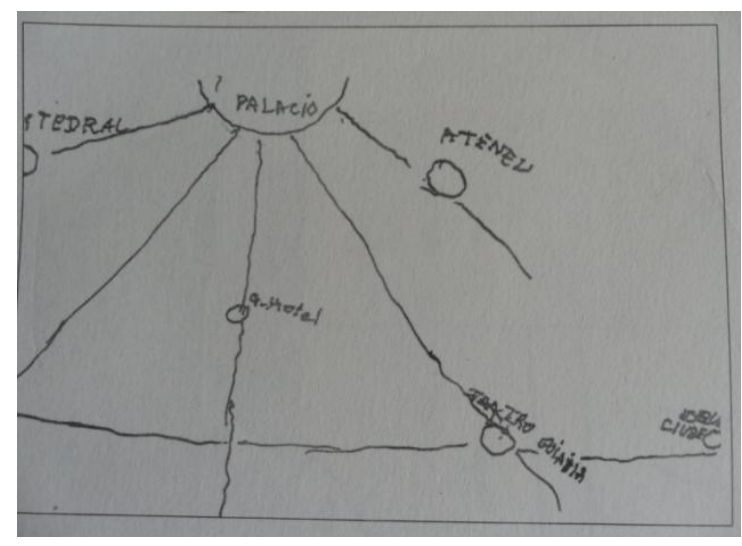

Figura 37. Mapa de memória de Dona Armênia Souza. Fonte: Medeiros 2007

O único mapa de memória publicado no artigo de 2007 que não foi produzido por um cidadão "notável” foi o de José Mendonça Ribeiro, que trabalhava no Mercado Central no ano de 1950. Nesse mapa, o único em que o norte aparece voltado para cima, o Mercado Central ocupa a posição central, entre as avenidas Anhanguera e Paranaíba. Ao norte, são identificadas quatro ruas longitudinais do antigo Bairro Popular, e no centro, logo acima do mercado, duas ruas latitudinais paralelas à avenida Paranaíba. $\mathrm{O}$ eixo monumental norte-sul, no entanto, está mal representado nesse mapa. Não fica claro quais avenidas são representadas, pois seu traçado e a posição do mercado não coincidem com as ruas do Bairro Popular indicadas no mesmo mapa. Se tomarmos o mercado como referência, as duas linhas deveriam indicar as avenidas Araguaia e Tocantins, pois a avenida Goiás passa à esquerda do antigo Mercado Central, e não à direita. Trata-se de um mapa produzido por alguém que aparenta estar distanciado dos símbolos do poder (Medeiros 2007: 225). 


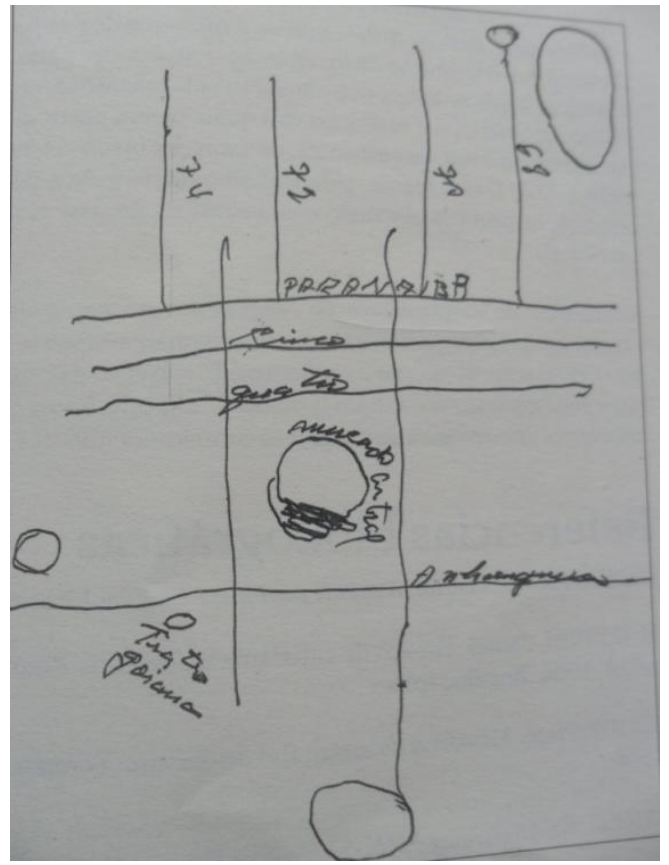

Figura 38. Mapa de memória de José Mendonça Ribeiro. Fonte: Medeiros 2007

F) As edificações e vizinhanças residenciais de padrão médio e baixo:

O “fachadismo residencial", já referido, indicado por Gonçalves (2002) na antiga cidade-satélite de Campinas ${ }^{67}$, ocorreu também na rua 24, no Setor Central, como mostram diversas residências que existem ainda nessa rua. De acordo com Badan (2007), as casas da rua 24 se diferenciavam das casas da rua 20. Para além de suas fachadas, as residências da rua 24 se assemelhavam às "casas de funcionários", o padrão médio das primeiras construções na década de 30:

A rua 24, habitada substancialmente por ex-moradores da cidade de Goiás, apresentava nos frontões de várias casas, elementos decorativos neoclássicos (brasões, cártulas, espiralados finos de folhas de acanto) (...). Ainda que estes elementos da arquitetura exterior sejam uma constante, as pesquisas in loco demonstraram que as moradias da rua 24 obedecem, geralmente, à mesma tipologia interior das casas dos funcionários descritas por Ofélia Monteiro em seu Livro “Como nasceu Goiânia” (Badan 2007: 131).

As ruas 20 e 24 aparecem relacionadas no depoimento de Salomão Rodrigues, que residia no Bairro Popular (Setor Norte) na década de 40: "as ruas principais que tinha, era a rua 20. Depois aquela outra em seguida...é a 24. Eram as ruas mais habitadas" (Santana, Bonetti e Macêdo 2007: 156).

Os depoimentos colhidos por Santana, Bonetti e Macêdo (2007) trazem ainda memórias sobre o modo de distribuição de moradias nos primeiros tempos de Goiânia,

${ }^{67}$ Embora possuísse em seu centro residências e edifícios comerciais "fachadistas", Campinas contava com a maioria de suas residências construídas rusticamente, "segundo o secular modo tradicional" (Oliveira 1999: 61). 
nas décadas de 30, 40 e 50. As doações de terrenos eram comuns no Setor Norte e, logo depois, em áreas de legalização de ocupações ilegais, como confirmam Gonçalves (2002) e Bernardes (1998). O depoimento a seguir situa geograficamente a área inicial de aplicação do "paternalismo" do Estado: "se vinha mudar para Goiânia, o doutor Pedro Ludovico dava o lote da Paranaíba para baixo". (trecho de depoimento de Salomão Rodrigues, coletado por Santana, Bonetti e Macêdo 2007: 156).

Levando em conta as informações disponibilizadas referentes à localização e qualificação normativa ${ }^{68}$ das residências produzidas a partir dos momentos iniciais da história de Goiânia, apresentam-se na cidade principal: (a) um desenvolvimento de vizinhanças residenciais de padrão médio, situadas próximas às vizinhanças de alto padrão que se formavam; (b) um desenvolvimento de vizinhanças residenciais de padrão médio-baixo distanciadas ao norte; e (c) as residências ilegais de padrão mais baixo inicialmente situadas a leste, nas margens do Córrego Botafogo, cuja transformação em parkway jamais ocorreu. O depoimento abaixo apresenta uma descrição que me parece precisa, do ponto de vista de quem habitava as vizinhanças de alto padrão:

Nos anos dourados, nos anos 50, nós dizíamos assim: Goiânia está dividida, da Avenida Paranaíba para cima [sul], que é o Palácio, era a nata da sociedade que morava, da Avenida Paranaíba para baixo [norte], era a classe média baixa. Então, as pessoas tinham essa rivalidade. Então você queria falar alguma coisa assim, negativa de alguém, Ah fulano é...não é do lado sul. Ela mora além da Avenida Paranaíba. A Avenida Paranaíba era um divisor, um divisor entre as classes sociais e até hoje isso existe. Você mora onde? Ah no bairro do buraco? Sempre existiu. E Botafogo, ali eram invasores, eram lavradores, empregadas domésticas (...). (Depoimento de Nise de Freitas, coletado por Lima filho 2007: 252).

G) O primeiro distrito de alto padrão:

\footnotetext{
${ }^{68}$ Como já foi mostrado, essas residências eram também modelos para futuras construções. Além disso, residências de estilo "tradicional" (de adobe) estavam oficialmente proibidas na cidade de Goiânia, embora existissem ali em grande quantidade, geralmente aglomeradas em vizinhanças marginais (Oliveira 1999: 60-61). Em fotografias antigas, é possível constatar que essas moradias de adobe (havia também edificações comerciais assim construídas, principalmente em Campinas) eram geralmente aquelas de padrão mais elevado dentre as construções ilegais, que contavam também com edificações de madeira e choupanas.
} 


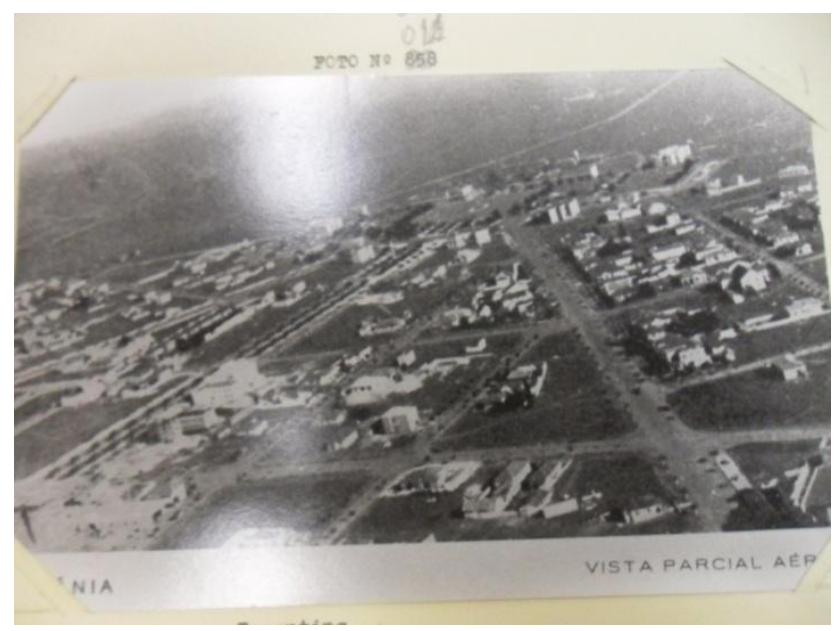

Figura 39. Foto aérea do Setor Central no início da década de 40, com a Praça Cívica ao fundo: notar as ruas de terra e a baixa densidade de edificações, mas a ocupação do terreno foi muito rápida.

A partir do panorama desolado de construções dispersas em campo aberto na década de 30, a cidade de Goiânia foi rapidamente se adensando com as aceleradas taxas de crescimento da época ${ }^{69}$. Mas tratava-se ainda de uma cidade horizontal, na qual:

A percepção global da cidade era possibilitada pela inexistência de barreiras naturais e favorecida por uma preponderante horizontalidade das edificações. Durante as décadas iniciais de Goiânia, apesar de permitida a construção de edifícios de até oito pavimentos, sobressaía-se a horizontalidade, com edifícios de, no máximo, três pavimentos. A amplitude de visão se devia não apenas às ruas largas da cidade moderna, amplas, projetadas para fazer funcionar a ideologia do higienismo, mas também aos efeitos da perspectiva das principais avenidas que privilegiavam a visão da Praça Cívica pelo transeunte, o que foi previsto pelo urbanista (Medeiros 2007: 220-221).

O rápido crescimento populacional e a proibição de novos loteamentos que perdurou até 1951 (Gonçalves 2002: 56), levou a uma valorização geral dos terrenos na capital, o que foi uma justificativa para a abertura dos loteamentos (Bernardes 1998: 196). Com isso:

Em 1947, as condições de aluguéis eram precárias. (...) O aluguel era muito caro na Zona Central. (...) A classe de baixa renda tinha que se contentar com os barracos que haviam no Botafogo, Vila Nova e Vila Militar. As leis do inquilinato não eram respeitadas e os proprietários praticavam abusos de toda natureza. (Cordeiro 1989; apud Bernardes 1998: 197).

Ainda que valorizada em relação à sua periferia, a cidade principal apresentava uma diferenciação interna, que ocorria razoavelmente de acordo com o esquema original dos construtores. Houve a formação um distrito de padrão médio-baixo ao

\footnotetext{
${ }^{69}$ A população urbana de Goiânia em 1940 era de 18.889 habitantes, desses mais de $40 \%$ viviam na cidade-satélite de Campinas. Em 1950, a população urbana era de 40.333 habitantes; em 1955, era de 74.781. Em 1960 elevava-se para 133.462 (Oliveira 1999: 47).
} 
norte, o Bairro Popular, com seu próprio mercado, o Mercado Popular, construído em 1952 (Gonçalves 2002: 73), com uma escola técnica, com a Estação Ferroviária (inaugurada em 1950) e com a penitenciária, um equipamento público situado próximo àquelas pessoas que deveria "abrigar".

Logo ao sul, já no Setor Central $^{70}$, entre a avenida Paranaíba e a avenida Anhanguera, a partir das construções iniciais da rua 4, onde foram construídas as casas para "funcionários", houve a formação de vizinhanças residenciais de padrão intermediário. Essas vizinhanças se situaram próximas à mencionada rua 4, onde se desenvolveu uma extensão exclusivamente varejista do comércio dos imigrantes síriolibaneses, inicialmente instalados em Campinas.

Ao Sul da avenida Anhanguera, houve a formação de um distrito de alto padrão, o que coincide com as seguintes afirmações de Oliveira (1999: 63):

Em Goiânia, os funcionários públicos mais graduados, juntamente com os políticos e alguns fazendeiros, formavam uma espécie de aristocracia fechada, com seus divertimentos próprios (como as festas no Jóquei Clube ou na casa de famílias), sua educação própria (...), seu próprio time de futebol, suas moradias próprias (...) etc.

Interiores ao distrito de imóveis de alto padrão, haviam áreas de edificações residenciais de padrão alto e médio ou médio-alto. É possível identificar também uma tendência de estruturação residencial de alto padrão em torno de dois imóveis, que serão considerados imóveis estruturadores: A rua 20 e a Praça Cívica. Já os imóveis comerciais de alto padrão se dispunham ao longo do eixo da avenida Goiás, entre a avenida Anhanguera e a Praça Cívica e em torno da Praça do Bandeirante, no principal cruzamento da cidade, entre a avenida Goiás e a avenida Anhanguera.

70 Daher (2003: 263) confirma que, em 1951, “as classes privilegiadas continuavam a ocupar o Setor Central, onde se encontravam ainda os melhores equipamentos de infraestrutura física da cidade e também serviços como bancos, comércio, teatro, cinema, hospitais, escolas, restaurantes, clubes e áreas verdes de lazer". 


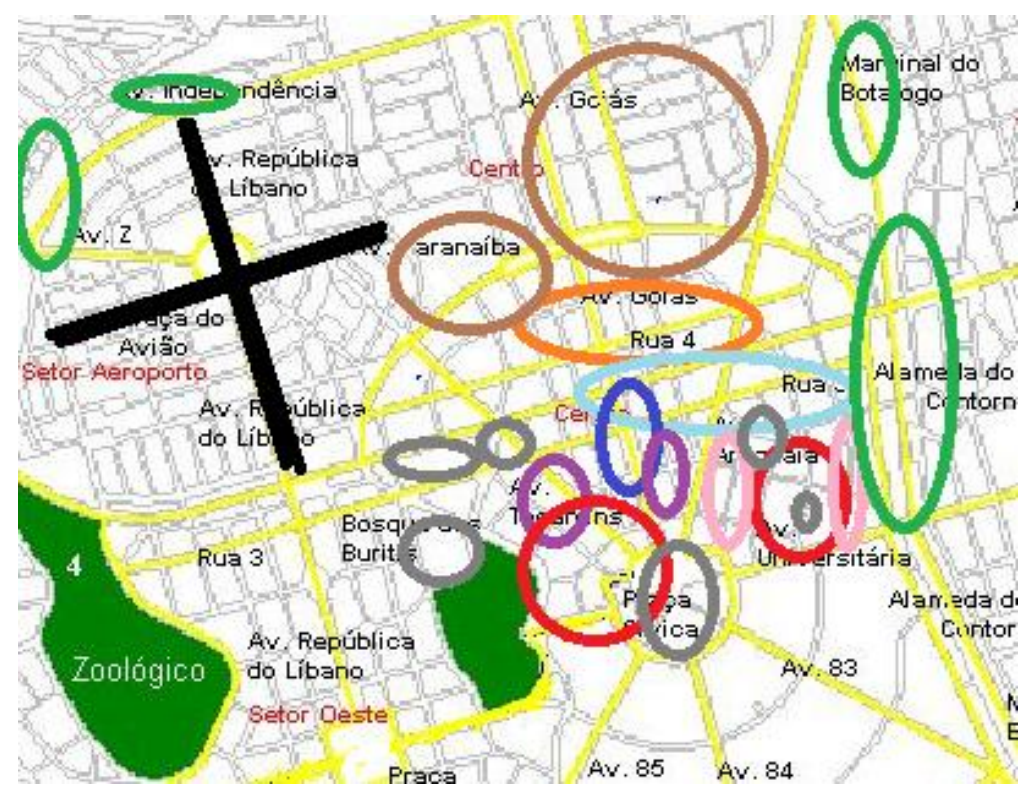

Figura 40. O distrito de imóveis de alto padrão em Goiânia e vizinhanças circunvizinhas, entre as décadas de 40 e 50. Como componentes do distrito de alto padrão, apresentam-se: (a) a área de residências de alto padrão situada entre a Praça Cívica e o Bosque dos Buritis, em vermelho; (b) a área de residências de padrão alto e médio orientada em torno da rua 20. Essa área inclui as residências de alto padrão da rua 20, mostradas em vermelho, e também as casas-tipo 4Q da rua 7 e as casas "fachadistas" da rua 24, representadas em rosa; (c) os bares, lanchonetes e sorveterias que atendiam à elite, em roxo; (d) a faixa de hotéis em edifícios art déco em azul escuro; (e) a faixa de lojas comerciais em edifícios art déco; (f) em cinza, a Praça Cívica, o Jóquei Clube, o Cine Teatro Goiânia, o Ateneu, o Liceu e a Faculdade de direito. O distrito está limitado ao norte e a leste por áreas de padrão mais baixo: (a) as vizinhanças de "funcionários" e a faixa de comércio da rua 4 em laranja; (b) as vizinhanças do Bairro Popular em marrom; (c) as vizinhanças marginais do Bairro Botafogo e do Bairro Capim Puba em verde. A cruz negra representa o aeroporto. Ao sul e a oeste do distrito de alto padrão, havia o vazio das áreas do Estado ainda a serem loteadas.

\subsection{Os resultados da aplicação do método}

A aplicação do método levou à confecção de uma série de mapas da disposição dos elementos de alto padrão de Goiânia. Como o processo estudado pode ser geralmente definido como um processo de expansão do centro da cidade ${ }^{71}$, a periferia fica de fora do âmbito desta pesquisa, já que lido com os imóveis de alto padrão. Por isso, os mapas resultantes são mapas do "centro" da cidade, apresentados na escala do modelo de Hoyt e na escala do modelo de Griffin e Preston, mas não na escala do modelo de Burgess. Em primeiro lugar, são apresentados os mapas na escala do modelo de Griffin e Preston, indicando núcleos e faixas de alto padrão, representados sobre um mapa turístico da cidade de Goiânia obtido na SEPLAM, que indica as principais edificações públicas, assim como as áreas verdes, da parte central da cidade. Em

\footnotetext{
${ }^{71}$ No sentido da distinção centro-periferia.
} 
segundo lugar, são apresentados os mapas resultantes da aplicação do modelo de Hoyt à cidade de Goiânia, confeccionados pelo autor desta pesquisa.

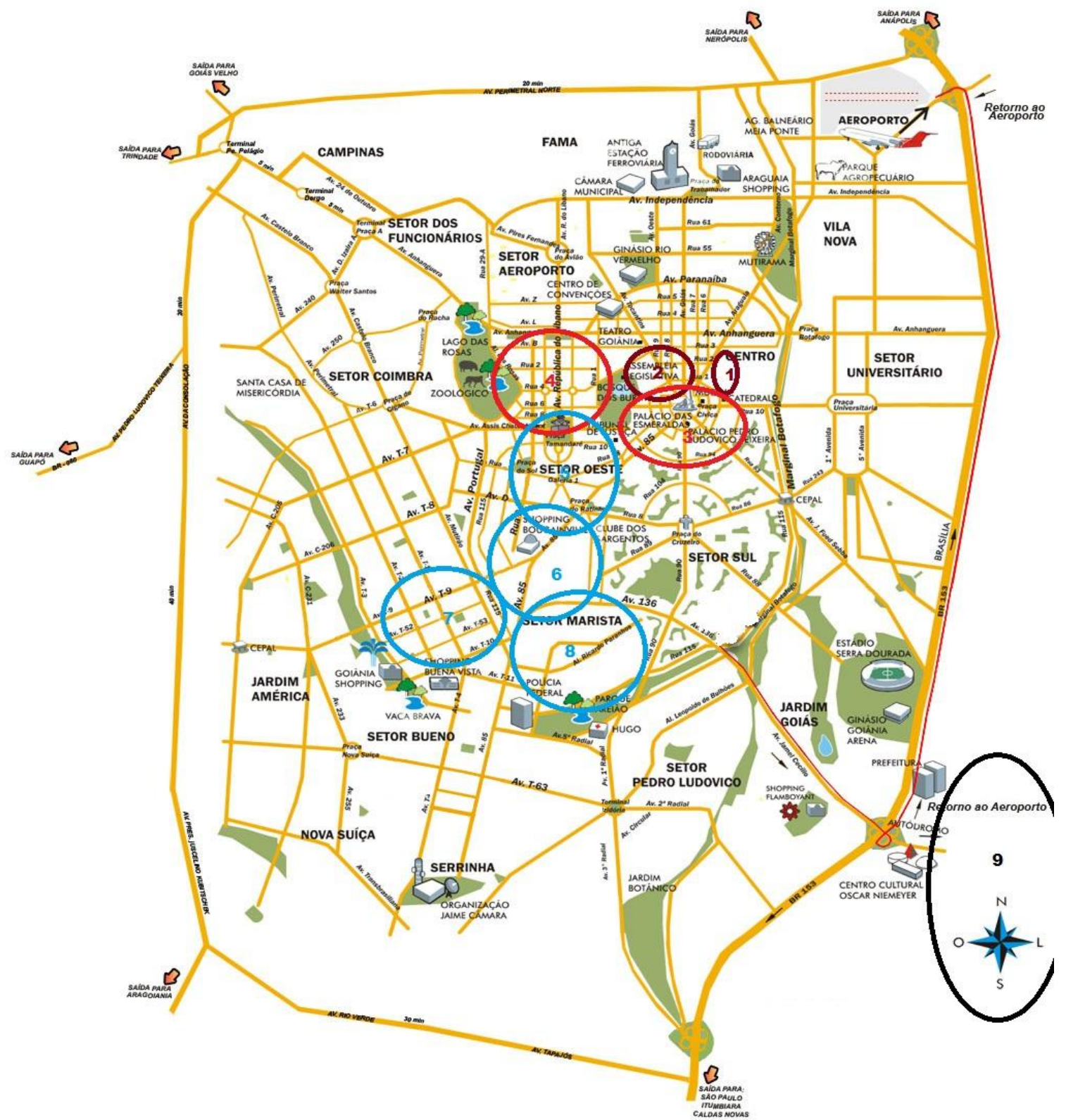

Figura 41. Áreas residenciais horizontais identificadas pela pesquisa e situadas à frente da expansão dos bairros de alto padrão de Goiânia. Em vermelho escuro, estão as primeiras áreas residenciais de alto padrão: a faixa de casas-tipo especial da rua 20 (1), e as vizinhanças de alto padrão situadas próximas à Praça Cívica e ao Bosque dos Buritis (2). Em vermelho, as áreas residenciais de alto padrão que se desenvolveram a partir do início da década de 50, quando do arruamento das etapas iniciais dos setores Sul e Oeste: a área de residências de alto padrão do Setor Sul (3), que se manteve próxima da Praça Cívica, e a área residencial do Setor Oeste (4), situada entre dois parques. Em azul, as áreas residenciais de alto padrão que se formaram a partir da expansão do loteamento do Setor Oeste, na década de 60, e avançaram ao sul, ocupando as áreas que hoje compõem o Setor Marista e parte do Setor Bueno: a área residencial da segunda fase de expansão do Setor Oeste (5), a área residencial da última fase de expansão do Setor Oeste, que incorporou áreas antes pertencentes ao Setor Sul e hoje fazem parte do Setor Marista (6); a área de residências de alto padrão do Setor Bueno (7); a área residencial de alto padrão que ocupou 
partes do Setor Pedro Ludovico e atualmente pertence ao Setor Marista (8). Essas áreas representadas em azul ocuparam vazios urbanos situados sempre à frente de sua frente de expansão a partir do Setor Oeste. No entanto, na década de 80 não havia mais áreas não urbanizadas para a produção de loteamentos diferenciados e o processo expansão para o sul das residências de alto padrão cessou. No final da década de 90 tem início o "salto" para o sudeste, com a produção de vários condomínios horizontais fechados em um vazio urbano situado a sudeste da cidade. A nova área está representada em preto (9).

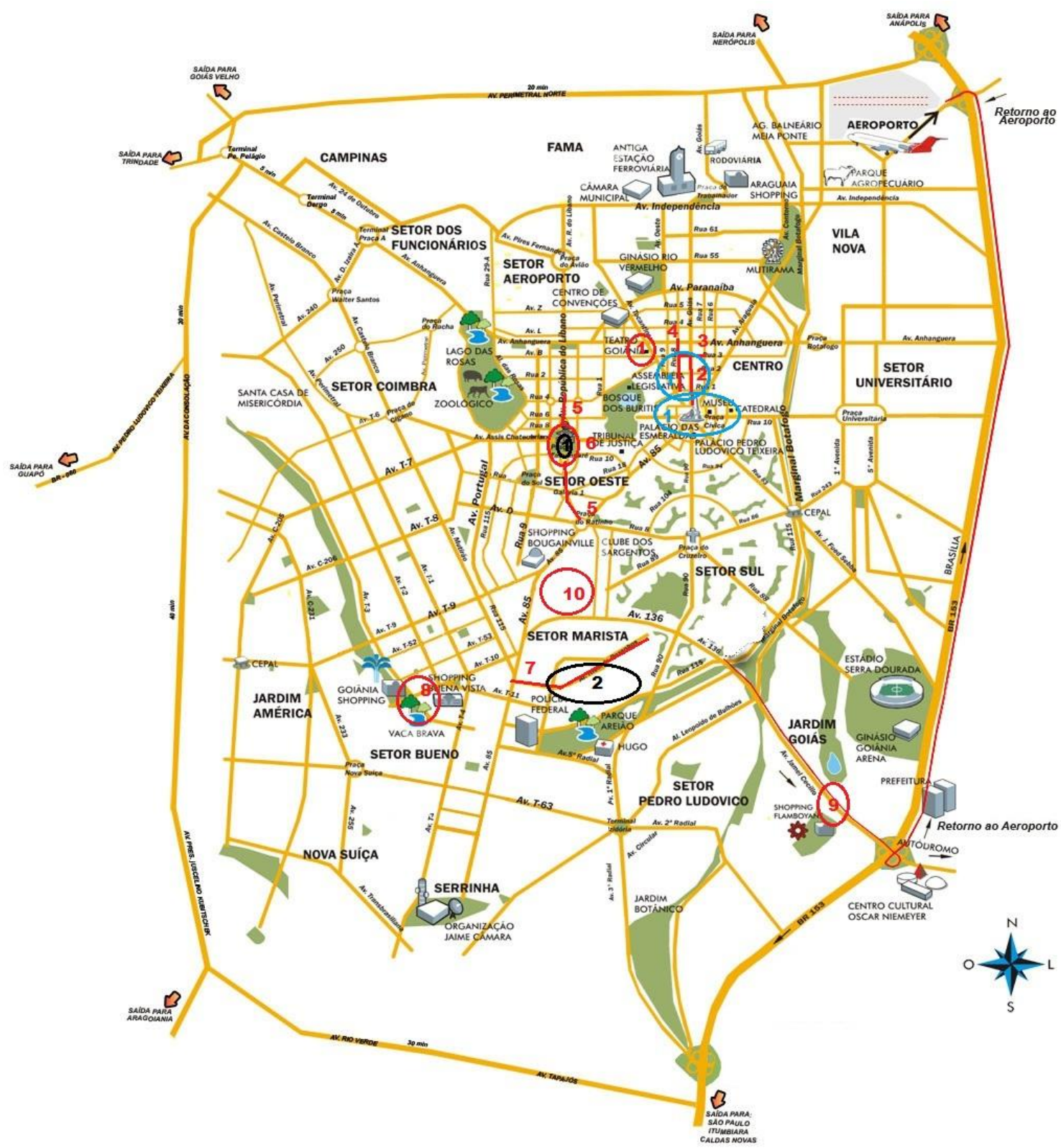

Figura 42. O footing e a diversão noturna de alto padrão em Goiânia. Em azul, os locais da prática do footing tradicional em Goiânia, ao redor da Praça Cívica (1) e entre esta e o Cine-Teatro Goiânia (2). Em preto, o "footing motorizado", praticado entre as décadas de 70 e 90, na Praça Tamandaré (1) a princípio, e posteriormente na avenida Ricardo Paranhos (2), respectivamente nos setores Oeste e Marista. Essas práticas de sociabilidade acompanharam o desenvolvimento dos imóveis de alto padrão para o Setor Oeste, e a partir dele, para o sul. As concentrações de bares e casas noturnas de alto padrão de Goiânia seguiram o mesmo sentido, e compuseram historicamente uma parte do setor de usos do solo associados de alto padrão. Em vermelho, estão representados: (1) a área destinada a "diversões" no plano diretor inicial de Goiânia, onde foi construído o Cine-Teatro Goiânia; o trecho sul da avenida Goiás (2), local da mais antiga concentração de bares, restaurantes e confeitarias de alto padrão e destinada no plano original a usos comerciais diversos de alto padrão; trecho da rua 3 (3), local onde se situou o Café Central e alguns 
bares e restaurantes, já na década de 40; trecho da rua 8 (4), local de concentração de bares e casas noturnas de alto padrão a partir da década de 50; Na década de 70, formou-se uma concentração de bares e casas noturnas de alto padrão ao longo da avenida República do Líbano (5) e ao redor da Praça Tamandaré (6), no Setor Oeste. No final da década de 80, desenvolve-se uma faixa de bares de alto padrão ao longo da avenida Ricardo Paranhos (7), no Setor Marista. Na década de 90, formam-se áreas de concentração de bares e casas noturnas situadas próximas a shopping-centers, no Setor Bueno e no Jardim Goiás (9). Já no novo século, desenvolve-se uma nova concentração de bares, restaurantes e casas noturnas do mais alto padrão da cidade, se sobrepondo a uma antiga área residencial de alto padrão no Setor Marista (10).

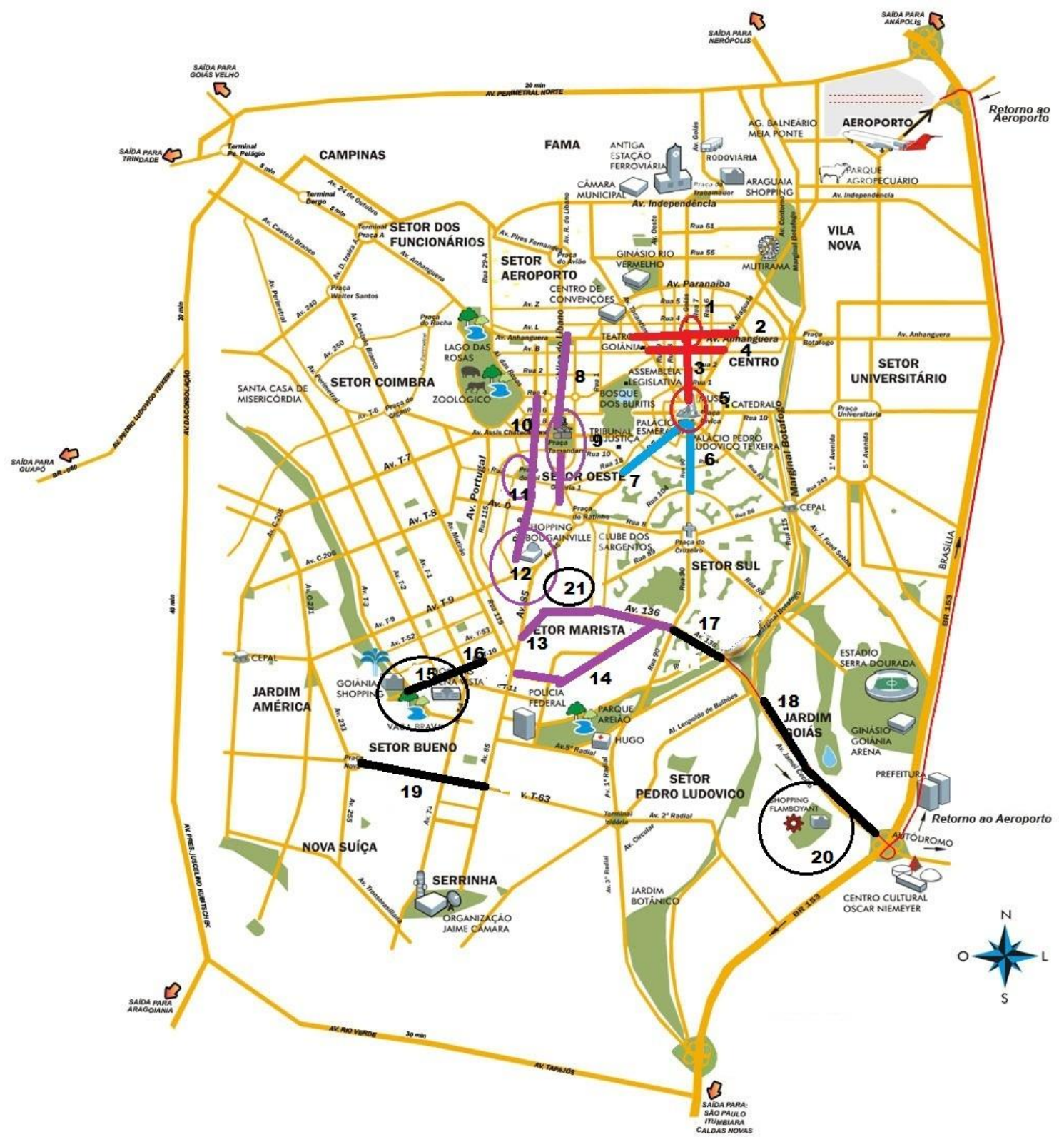

Figura 43. Núcleos e faixas de comércio varejista, serviços, hotéis e escritórios de alto padrão em Goiânia. Em vermelho, estão os núcleos e faixas do distrito original da cidade, com o núcleo bancário e de escritórios da Praça do Bandeirante (1), o trecho da avenida Anhanguera que concentrou casas de comércio de alto padrão (2), o trecho sul da avenida Goiás (3), que concentrava hotéis, restaurantes e comércio de alto padrão, além de apartamentos residenciais, e o trecho da rua 3 (4) que também concentrava edifícios construídos no estilo art-déco ocupados por hotéis e casas comerciais de alto padrão. Já a Praça Cívica (5) era um núcleo predominantemente administrativo e residencial, mas também apresentava uma concentração de atividades comerciais de alto padrão. Em azul, estão as faixas comerciais de alto padrão do Setor Sul, visíveis em fotos aéreas do início da década de 60, nas ruas 84 (6) 
e 85 (7). No Setor Oeste, a partir da década de 70, tornam-se evidentes a faixa comercial da Avenida República do Líbano (8), onde foram construídos os hotéis de mais alto padrão da cidade, nas décadas de 80 e 90, e o núcleo da Praça Tamandaré (9), atualmente a maior concentração bancária de Goiânia. Ao longo da rua 9 (10), desenvolveu-se a partir da década de 70 uma faixa de comércio varejista de alto padrão, especialmente de vestuário, que concentrava também serviços e restaurantes. Dois núcleos se formaram nas imediações. O primeiro, ao redor da Praça do Sol (11) apresentava inicialmente bares, restaurantes e casas noturnas, além de concentrar edifícios residenciais verticais de luxo em sua parte norte. Com o plano diretor de 2007, abriu-se a possibilidade de verticalização em todo o redor da praça e a área recebeu mais edifícios residenciais de alto padrão, além dos assim chamados "edifícios inteligentes", de escritórios e lojas. O segundo núcleo formou-se em torno do Shopping Bougainville (12), inaugurado em 1990. Igualmente, esse núcleo passa atualmente por um processo de verticalização decorrente das mudanças no zoneamento urbano nessa parte do Setor Marista. No fim da década de 80, formaram-se as faixas da avenida 136 (13) e da avenida Ricardo Paranhos (14). A primeira faixa era composta originalmente por edifícios residenciais verticais do mais alto padrão e por estabelecimentos comerciais horizontais. Atualmente abriga também os "edifícios inteligentes". A segunda faixa permanece horizontal, pois não se podem construir ainda edifícios com mais de três andares na área. A partir de meados da década de 90, com a urbanização do Parque Vaca Brava e a construção do Goiânia Shopping, desenvolveu-se o núcleo do Parque Vaca Brava (15) e a faixa da avenida T-10 (16). A partir do final dessa década, desenvolveram-se extensões da faixa da avenida 136, dos dois lados do Córrego Botafogo (17 e 18). A presença de "edifícios inteligentes" ao longo da avenida T-63 levou à inclusão dessa faixa (19), embora exista ao redor dessa faixa uma área verticalizada com predominância de imóveis residenciais de padrão médio. Já no século XXI, forma-se um núcleo de hotéis e "edifícios inteligentes" ao redor do Shopping Center Flamboyant (20), que já havia sido inaugurado há duas décadas (1981) quando ocorre essa concentração em seu entorno. Por fim, já na segunda metade da primeira década do novo século, desenvolve-se um núcleo de restaurantes, bares e casas noturnas de alto padrão, além de serviços, em uma área de alto padrão predominantemente residencial e horizontal do Setor Marista (21).

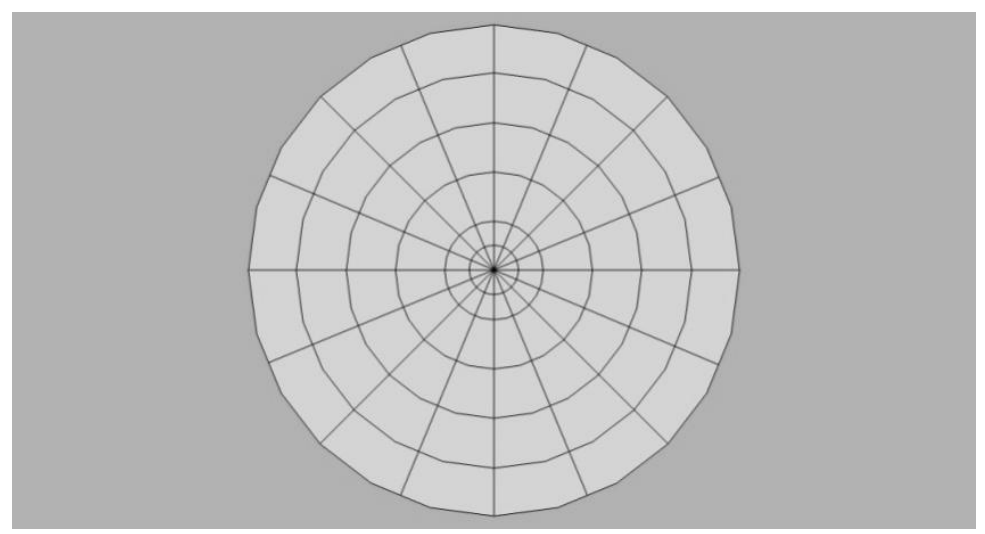

Figura 44. Mapa básico desenvolvido para a representação do modelo de Hoyt em Goiânia. Com exceção do círculo mais interno, cada círculo concêntrico representa uma distância de $1 \mathrm{~km}$ a partir da Praça Cívica. O círculo mais interno representa uma distância de $500 \mathrm{~m}$ da Praça Cívica. Assim, o mapa se estende até uma distância de $5 \mathrm{~km}$ da Praça Cívica. 


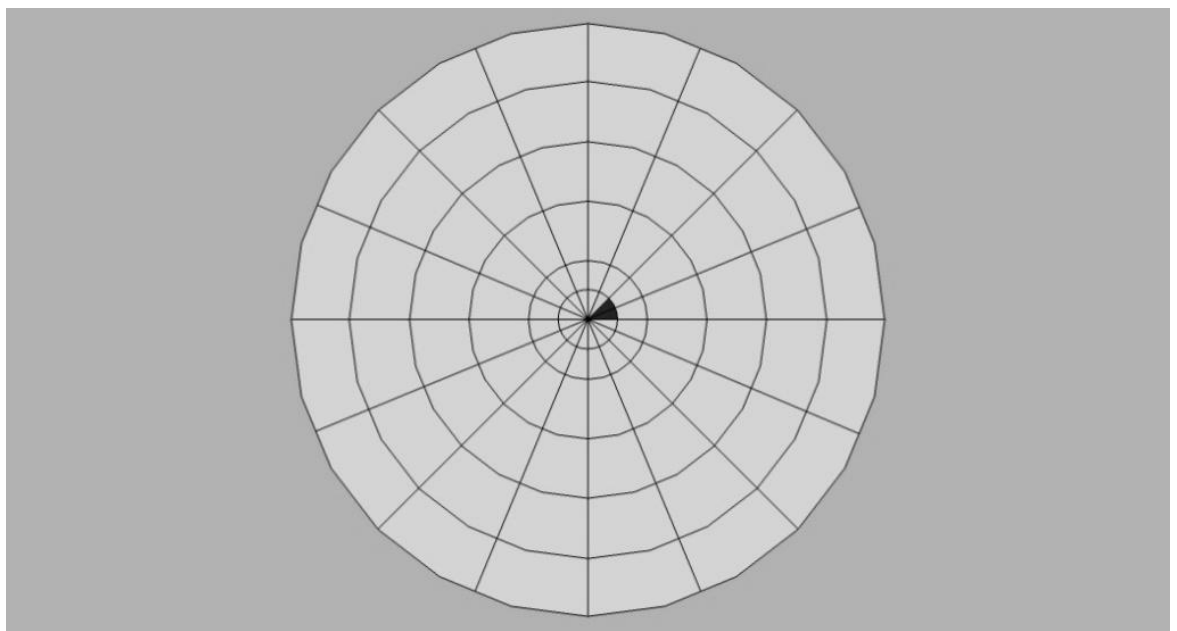

Figura 45. A área inicial de imóveis associados de alto padrão, entre a rua 24 e a rua 7, formada na década de 30, antes mesmo da inauguração do centro cívico. A faixa central dessa área inicial é a rua 20 , que abrigou provisoriamente, em algumas construções destinadas a fins residenciais, as funções centrais de administração pública até a inauguração do centro cívico.

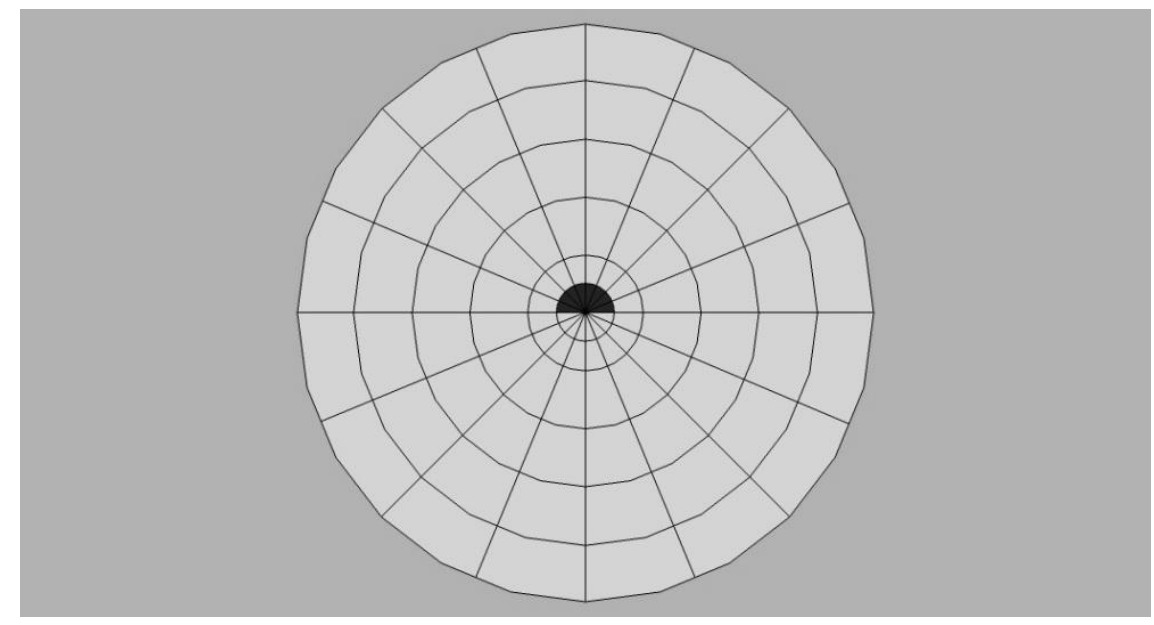

Figura 46. O distrito original dos imóveis de alto padrão nas décadas de 40 e 50 . O distrito se desenvolveu de acordo com o planejamento dos criadores da cidade.

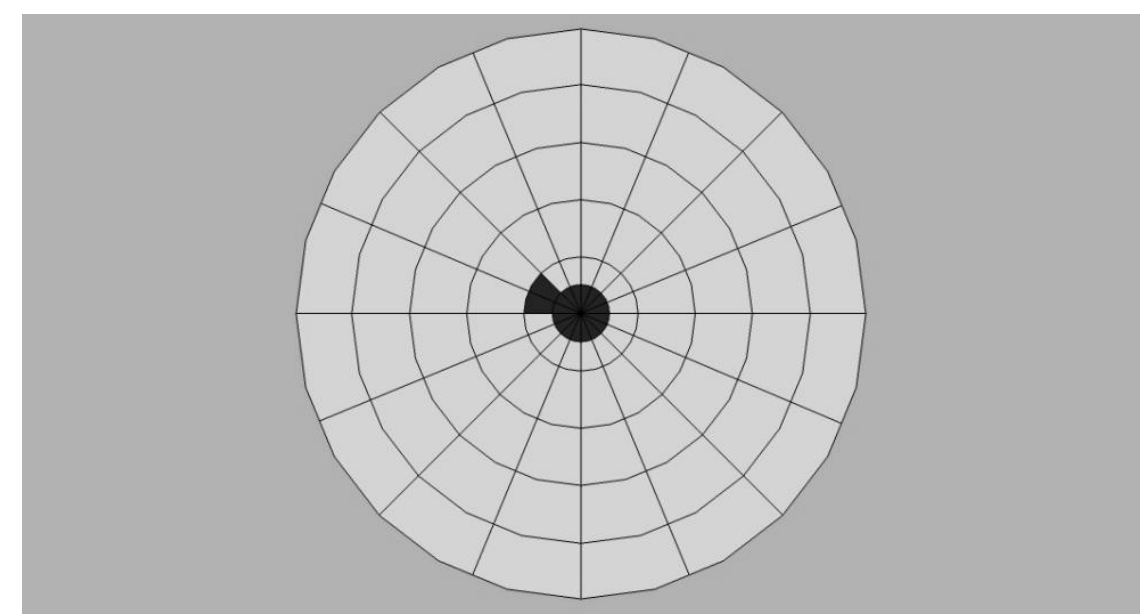

Figura 47. O setor de imóveis associados de alto padrão nas décadas de 50 e 60 , com a expansão do distrito original para o sul e a formação de um distrito adjacente no Setor Oeste. 


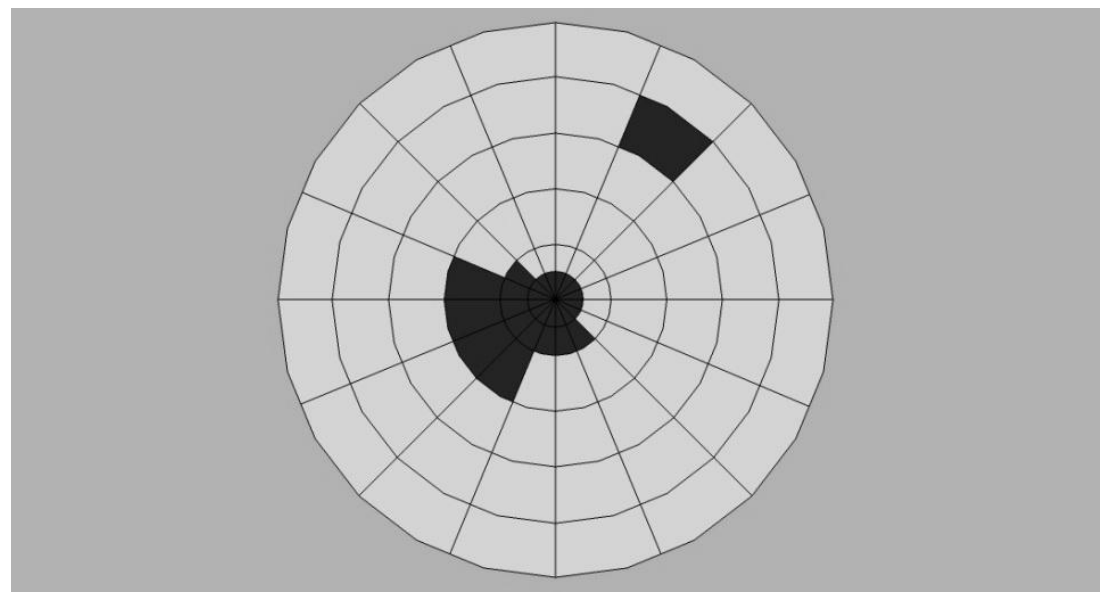

Figura 48. O setor de imóveis de alto padrão na década de 70. O desenvolvimento mais intenso se dá para oeste e sudoeste, e não diretamente ao sul, como havia sido originalmente concebido pelos criadores da cidade. Pode-se dizer que o Setor Oeste se torna o setor escolhido pela classe dominante, em detrimento do Setor Sul, originalmente destinado para abrigá-las. A área de alto padrão isolada ao norte é o Setor Jaó, loteado na década de 60 e significativamente ocupado a partir da década seguinte.

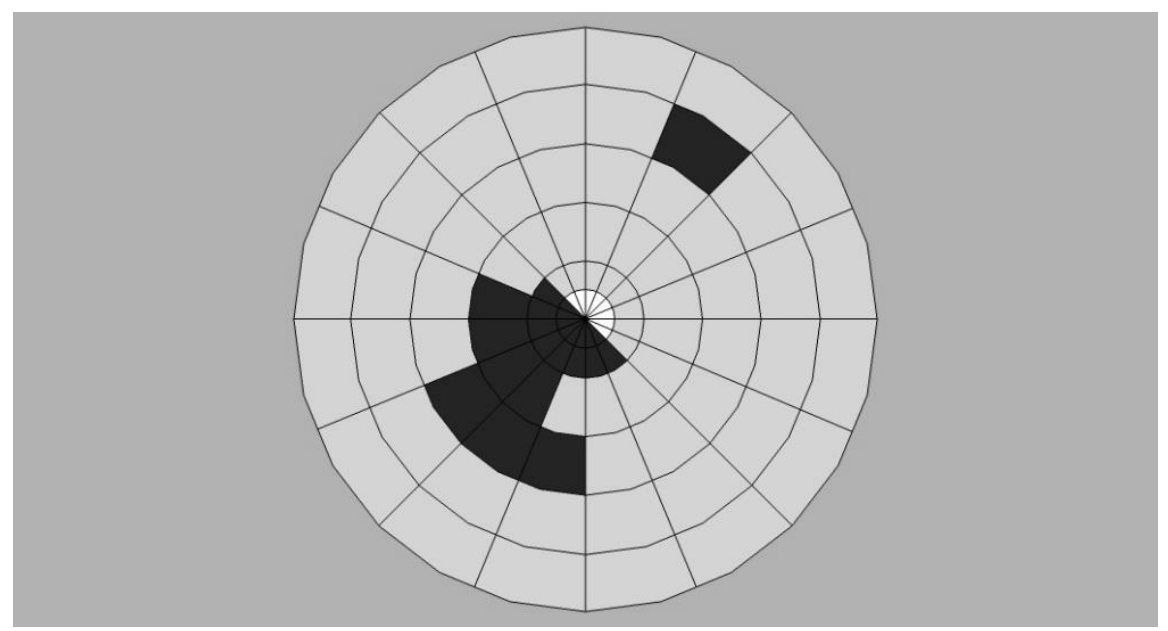

Figura 49. O Setor de imóveis de alto padrão nas décadas de 80 e 90 . Há nesse período um declínio notável desses imóveis no Setor Central da cidade, bem como a ocupação de todo o Setor Marista e de partes do Setor Bueno nas frentes de expansão ao sul e sudoeste. Nesse período a verticalização residencial de alto padrão começa a se estruturar significativamente em núcleos e faixas situados nos Setores Oeste, Marista e Bueno, em áreas anteriormente ocupadas por residências horizontais de alto padrão. 


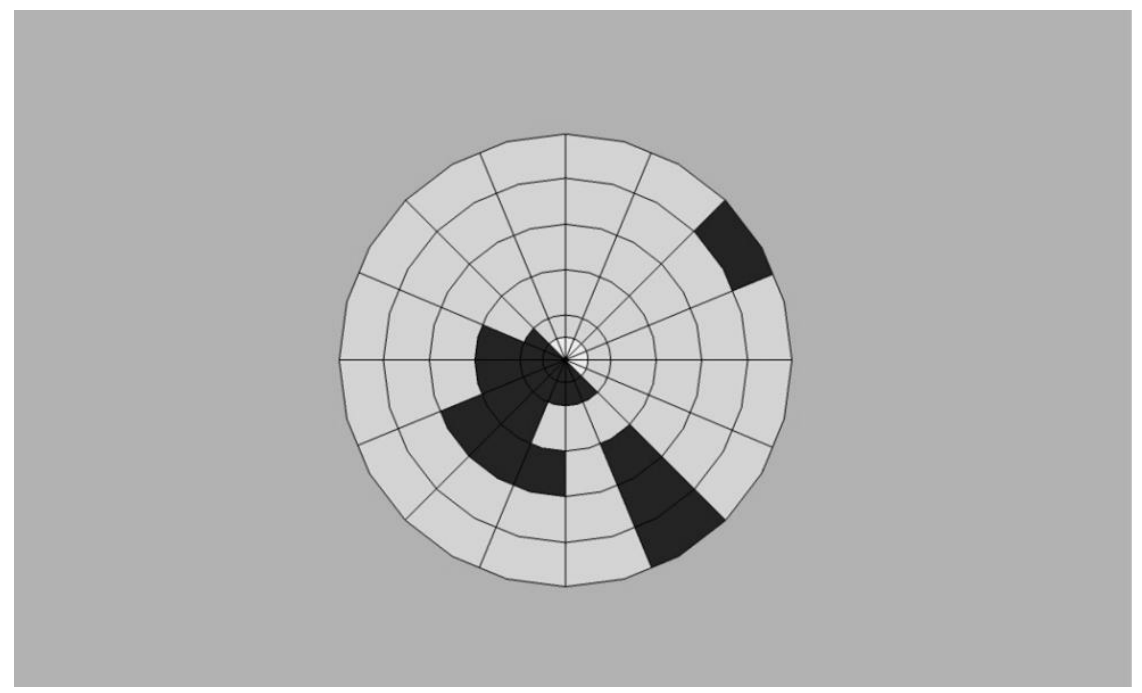

Figura 50. Os setores de imóveis de alto padrão em sua situação atual. O desaparecimento da área isolada ao norte indica a obsolescência dos imóveis de alto padrão no Setor Jaó, e o aparecimento de outra área isolada na mesma região, porém mais afastada do centro, representa o condomínio residencial fechado Aldeia do Vale, que se conecta com as novas áreas de alto padrão da parte sudeste da cidade pela rodovia BR-153, que corta a parte leste da cidade no sentido norte-sul. O setor original de imóveis de alto padrão, que vinha se desenvolvendo para o oeste e para o sul a partir da década de 50, foi flanqueado por outras áreas residenciais, particularmente pelas residências verticais de padrão médio que foram construídas ao redor da avenida T-63, e parou de se expandir, com o fim dos lançamentos de loteamentos "diferenciados" na frente de expansão. Procedeu-se então, a partir do final da década de 90, o "salto" da frente de expansão para os vazios urbanos da parte sudeste da cidade, cuja propriedade se concentrava nas mãos da família Louza. O "salto" gerou um novo setor de imóveis de alto padrão, conhecido pelos corretores imobiliários de Goiânia como o "vetor sudeste".

Os mapas apresentados são similares à descrição de Villaça dos padrões e do desenvolvimento das concentrações de imóveis de alto padrão nas metrópoles brasileiras, na medida em que os imóveis de alto padrão tendem a se concentrar na parte central da cidade, e seu crescimento segue em uma progressão axial limitada a um setor específico da cidade. Os mapas são também coerentes com o modelo de Griffin e Preston, pois mostram que, no interior do setor axial de desenvolvimento dos imóveis de alto padrão, esses imóveis tendem a se concentrar na forma de núcleos e faixas. Podem ser indicados aqui três padrões de concentração e desenvolvimento dos imóveis de alto padrão: (a) se apresentam concentrados próximos ao centro da cidade e fora da periferia; (b) se desenvolvem em um setor específico na direção sul, ou mais especificamente, se desenvolvem a princípio para o sul e o oeste, depois para o sudoeste e depois para o sudeste; (c) tendem a se dispor na forma de núcleos e faixas internos ao centro e ao setor de expansão para o sul.

Nesse ponto, destaco a obra de Villaça como uma influência central nesta pesquisa, porque sua adaptação do modelo de Hoyt para representar a estrutura sócioespacial das metrópoles brasileiras forneceu a esta pesquisa uma tripla possibilidade: (1) 
indicar semelhanças nos padrões de segregação sócio-espacial encontrados em Goiânia com os padrões descritos por Villaça em outras cidades brasileiras; (2) indicar semelhanças de padrões de segregação sócio-espacial no Brasil com padrões que ocorreram no país e na época de Hoyt; e (3) indicar que esses padrões são relacionados com grupos ou classes sociais.

\section{A questão sociológica}

\subsection{A motivação para a interpretação sociológica da estrutura urbana}

De acordo com Mário Eufrásio (1999), os estudos realizados pela Escola Sociológica de Chicago, entre 1915 e 1940, levaram ao desenvolvimento de um modelo da estrutura urbana e de uma interpretação ecológica da estrutura urbana. A interpretação ecológica da Escola de Chicago, no entanto, apresentava "a organização espacial da cidade como resultado de processos não-sociais, impessoais e inconscientes de competição e luta pelo sustento" (Eufrásio 1999: 186). Todavia, "as pesquisas empíricas que [as concepções teórico-conceituais ecológicas] suscitaram se defrontaram com a impossibilidade de encontrar (...) os dados e indicadores próprios das relações e processos não-sociais e inconscientes implicados por aquelas concepções ecológicas" (idem). Com isso, a explicação ecológica para a configuração urbana perdeu relevância em favor de uma tendência que Eufrásio denomina "socioeconômica", 72 que relacionava aspectos sociais e econômicos com a estrutura urbana da cidade (ibid.: 187).

Eufrásio destaca ainda a distinção entre a teoria da estrutura urbana, desenvolvida por Burgess, e a "corrente da ecologia humana teorizada por Park, Burgess e McKenzie” (Eufrásio, 1999: 248). Com o estabelecimento dessa distinção, que desvincula a teoria da estrutura urbana da corrente da ecologia humana, Eufrásio indica a possibilidade de realização de uma investigação sociológica da estrutura urbana que recorra a outro referencial teórico, superando o psicologismo e outras limitações da teoria social ecológica. Como exemplo, as concepções de Hoyt e Harris e Ullman acerca das forças que movem o padrão estrutural nas cidades norte-americanas podem ser lidas em uma chave weberiana:

\footnotetext{
${ }^{72}$ Como os estudos de Homer Hoyt e os de Griffin e Preston, por exemplo.
} 
(...) não há também necessidade de pressuposição de processos ecológicos subjacentes, já que seria a interação econômica (...) socialmente consciente - de um modo que certamente se poderia admitir, em termos de Weber, como racional com relação a fins - que promoveria a conformação e as alterações dos padrões urbanos. (ibid.: 249).

Assim, os problemas empíricos devidos à interpretação ecológica da estrutura urbana levam Eufrásio a indicar que "parece, pois, inútil e desnecessariamente complicador introduzir uma interpretação ecológica dos processos socioeconômicos envolvidos na estrutura da cidade e seu desenvolvimento" (ibid.), de modo que uma descrição da estrutura urbana poderia ter outro tipo de explicação sociológica, como no exemplo dado pelo autor de uma interpretação nos termos de Weber.

\subsection{A questão sociológica}

Dar uma resposta sociológica adequada a uma pesquisa empírica que não é necessariamente sociológica significa percorrer um caminho: aquele que parte do mapeamento histórico-geográfico dos usos e valores do solo urbano, através da seleção de objetos delimitados sincronicamente e em diferentes momentos, para o entendimento das relações sociais que podem estar por trás dessas mudanças.

$\mathrm{Na}$ verdade, a questão da explicação sociológica do objeto físico - submeter os objetos aos agentes ${ }^{73}$ - já é o desenvolvimento de uma questão básica, anterior a essa pesquisa, e aplicada aos autores norte-americanos da geografia e da economia urbanas do pós-guerra, cuja literatura é objeto de estudos nos seminários de sociologia urbana do $\mathrm{CERU}^{74}$. A questão que poderíamos apresentar a esses autores ${ }^{75}$ é a seguinte: $o$ que explica os as tendências de configuração dos elementos urbanos que foram descritas pelos senhores em suas pesquisas?

O desenvolvimento dessa questão é fruto da concepção, expressa no postulado de partida desta pesquisa, de que os padrões estruturais da cidade podem representar e serem associados aos padrões sociais dos indivíduos que ocupam a cidade. Trata-se de uma idéia de correspondência entre o espaço físico e os grupos sociais, que está

\footnotetext{
${ }^{73}$ Por mais que os objetos sejam dotados de valor ou de mana, eles ainda não podem ser produzidos de modo a agirem por si próprios. Se os objetos podem ser considerados agentes, são agentes de segundo grau, pela capacidade de inspirar, induzir, moldar, facilitar, possibilitar, restringir, impedir ou coagir a ação dos humanos. Sobre a agência dos objetos, cf. Appadurai 2008: 15-17.

${ }^{74}$ Centro de Estudos Rurais e Urbanos - FFLCH - USP. Estamos nos referindo a Hoyt, Preston e Griffin e Preston, e a Murphy e Murphy e Vance.

${ }^{75} \mathrm{E}$ que, no entanto, esses autores não nos parecem responder satisfatoriamente, pois se concentram na descrição e delimitação da estrutura urbana. Para Villaça, Hoyt identifica o processo de desenvolvimento residencial intra-urbano das elites, mas não o explica satisfatoriamente (Villaça, 2001: 198-199).
} 
presente na obra de Flávio Villaça, quando o autor busca identificar "quais os processos sócio-espaciais mais significativos" para a configuração estrutural das metrópoles brasileiras (2001: 25) ${ }^{76}$. O mesmo se dá quando o autor encontra marcas da luta de classes na estruturação da segregação urbana (idem: 45), de modo que as classes dominantes reservam para si os espaços considerados mais privilegiados. Ou, ainda, quando o autor destaca o papel da ideologia na estruturação da segregação espacial urbana (ibid.: 44$)^{77}$.

A primeira questão acerca do uso do método descritivo é a de por que utilizar um método descritivo para a análise sociológica da estrutura urbana. Não se trata apenas de buscar uma representação de grupos sociais pela correspondência com partes delimitadas do espaço urbano - trata-se de buscar uma explicação para essa correspondência. O fato de que o método descritivo utilizado de Hoyt possui as vantagens de verificar padrões específicos de disposição dos elementos da estrutura urbana foi aferido em Goiânia, mas para que servem essas vantagens em termos sociológicos?

Para um estudo da correspondência entre o espaço físico e o espaço social, os modelos de representação da estrutura urbana não são particularmente necessários, já que a simples tomada de um mapa de renda média dos bairros da cidade leva a acreditar que existem padrões de diferenciação social que podem ser e que são mapeados sobre o espaço físico. Além disso, como mostra Villaça, a comparação de diferentes mapas da cidade de São Paulo, que representam diferentes dados de qualificação dos imóveis e de seus ocupantes, mostra que os índices positivos estão associados e concentrados em áreas específicas do espaço urbano, o que indica uma correspondência entre o espaço físico da cidade e os estratos sociais que a ocupam (Villaça 2011: 43-46). Como segue nos exemplos de mapas sócio-espaciais abaixo, que possuem, no entanto, um caráter sincrônico e se referem a apenas um tipo específico de dados.

\footnotetext{
${ }^{76} \mathrm{Na}$ verdade, a idéia da correspondência está presente em toda a obra de Villaça: dos objetivos, um dos quais é o de "Relacionar os movimentos da estrutura territorial com os das estruturas sociais (lato sensu) e - o que é bem mais difícil - vice-versa" (Villaça, 2001: 12), até suas conclusões finais acerca da segregação sócio-espacial, quando explica que "Nas metrópoles brasileiras, a enorme desigualdade social produz espaços altamente desiguais". (idem: 357 ).

${ }^{77}$ Vera da Silva Telles, em seu artigo Trajetórias Urbanas: fios da descrição de uma cidade, irá se referir a Villaça para afirmar a associação entre a desigualdade social e a configuração urbana expressa pela noção de "segregação": "Como mostra Flávio Villaça, a noção de segregação diz respeito a uma relação entre localidades e a cidade. Não é uma relação física, dada pelas escalas de distância e proximidade, tal como se poderia medir no mapa da cidade. É uma relação social que diz respeito à dinâmica da cidade, aos modos como a riqueza é distribuída (e disputada) e corporificada nas suas materialidades, formas e artefatos (Harvey), definindo as condições desiguais de acesso a seus espaços, bens e serviços" (Telles 2006: 76. Grifos do original).
} 


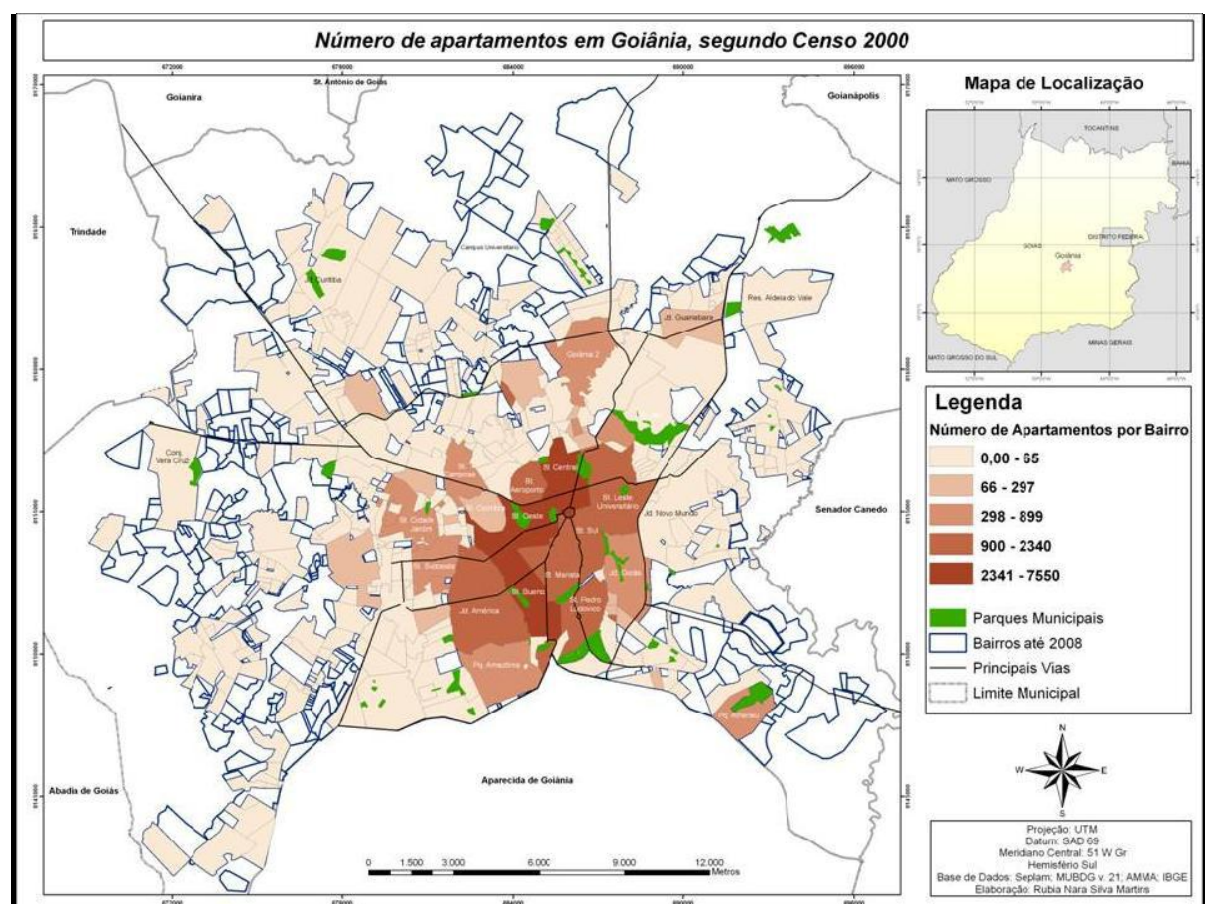

Figura 51. Mapa que representa o número de apartamentos por bairro de acordo com dados do Censo de 2000. O mapa revela os limites aproximados do centro em relação à periferia da cidade, bem como o do setor de alto padrão, embora não represente as áreas horizontais de alto padrão do Setor Marista, que aparecem com as cores do segundo nível mais alto de verticalização da legenda (900-2340 apartamentos por bairro). Os limites do centro ampliado podem ser associados à área de maior verticalização indicada pelos dois maiores índices de verticalização da legenda, enquanto o setor de alto padrão está, com a ressalva já feita, indicado pela área ocupada pelo maior índice de verticalização da legenda. É preciso notar que a relação entre a maior taxa de verticalização e o setor de alto padrão indica a atração exercida sobre atividades verticalizadas da centralidade de alto padrão pelas áreas residenciais de alto padrão, como foi constatado por Villaça (2001) em outras cidades brasileiras. Fonte: Martins 2010.

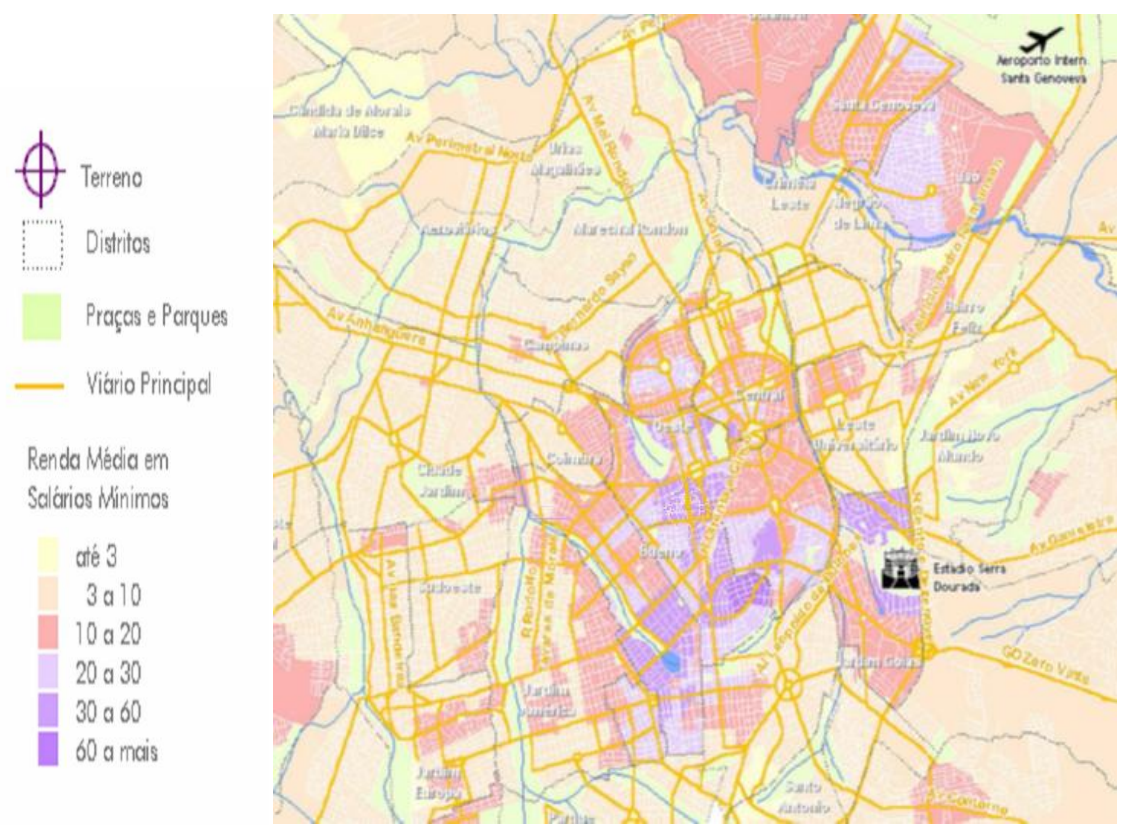

Figura 52. Mapa elaborado por Moysés e Borges (2009) com base nos dados do censo de 2000, que apresenta os índices de renda familiar média de Goiânia por quarteirões. Por indicar a renda dos moradores, trata-se de uma ferramenta de qualificação importante para esta pesquisa. Esse mapa mostra 
os limites aproximados do centro ampliado, quando consideramos a concentração principal de áreas com renda média superior a 10 salários mínimos; e mostra ainda o setor "hoytiano" de imóveis de alto padrão, quando tomamos as áreas ocupadas pelas duas categorias de rendas médias familiares mais altas, a partir de 30 salários mínimos. A única área indicada na mais alta categoria, a partir de 60 salários mínimos, corresponde às vizinhanças de residências horizontais de alto padrão do Setor Marista, dispostas entre a avenida Ricardo Paranhos. Quanto às residências horizontais de alto padrão, é preciso notar que a data das fontes do mapa (2000), registra apenas o início do movimento de ocupação das áreas a sudeste da cidade pelo distrito residencial horizontal de alto padrão dos condomínios fechados, situado além do estádio Serra Dourada, indicado no mapa. É possível notar ainda três sinais de gradientes de valor estabelecidos ao redor de parques urbanos, nos dois parques que limitam o Setor Oeste e na borda sul do Parque Vaca Brava, situado entre o Setor Bueno e a parte do Jardim América ocupada por habitantes com maior poder aquisitivo. Fonte: Moysés e Borges 2009.

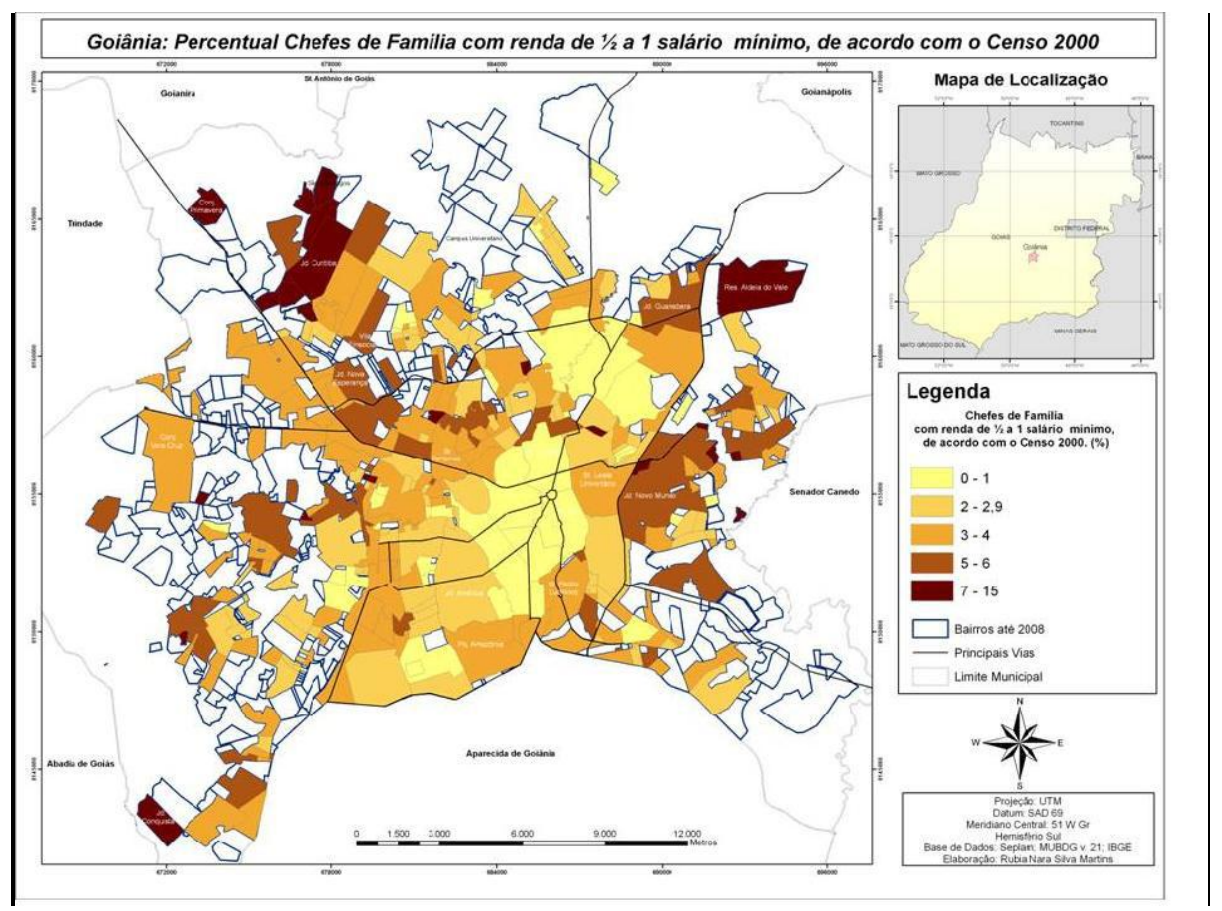

Figura 53. Exemplo de mapa do tipo centro-periferia, que indica a porcentagem de chefes de família com renda de $1 / 2$ a 1 salário mínimo, de acordo com dados do Censo de 2000. As cores mais escuras representam as maiores concentrações de chefes de família de baixa renda. Fonte: Martins 2010.

Se a produção de modelos da estrutura urbana não é comum na sociologia urbana brasileira recente, a concepção de que existem relações entre a configuração urbana e os grupos sociais é, por outro lado, bastante difundida. O tema da segregação sócio-espacial, abordado sob diversos pontos de vista ${ }^{78}$, é um dentre vários exemplos do estabelecimento dessa associação, e é um bom exemplo, pois se trata de um conceito que por si próprio exprime uma relação entre o espaço físico e a hierarquia ou a estratificação social. Esta pesquisa pode ser entendida como um estudo de segregação, com um viés focado na análise de um processo de longa duração e de amplo raio de ação. Se o modelo produzido por Villaça para representar a estrutura física das

${ }^{78}$ Cf. Frehse e Leite 2009. 
metrópoles brasileiras se refere de fato ao que poderíamos considerar a manifestação no espaço físico de uma forma de segregação social, então a abordagem proposta pode ter relevância para o entendimento de certas práticas coletivas de segregação, que partem de cima para baixo, em termos de hierarquias sociais, e que transcendem alguns períodos e lugares, ainda que possam ser eventualmente restritas ao contexto do capitalismo ou da modernidade ${ }^{79}$.

Nessa perspectiva, a resposta da questão levantada - de por que utilizar um método de representação da estrutura urbana em uma análise sociológica - se dá pela busca de uma demonstração detalhada e diacrônica do postulado de partida desta pesquisa, que é também um postulado da segregação sócio-espacial.

Em primeiro lugar, o método cartográfico de representação da estrutura urbana tem a possibilidade de registrar e corresponder diversos tipos de dados em um único modelo de representação, o que permite apresentar de forma homogênea e sintética as informações coletadas, em diferentes escalas de análise.

Em segundo lugar, a apresentação de mapas por períodos históricos permite uma observação diacrônica da estrutura sócio-espacial. Essa capacidade pode ser valiosa, dado que em Bourdieu há uma correspondência entre o espaço físico e o espaço social que pode cobrir mais de um século ${ }^{80}$. Além disso, com Hoyt e Villaça, há exemplos da possibilidade de descrever padrões de segregação sócio-espacial de longa duração, pois ambos os autores trabalham em suas obras com processos de amplo raio de ação ${ }^{81}$.

Portanto, o método descritivo oferece não apenas a possibilidade de testar o postulado de que o papel simbólico de representação social dos elementos dispostos no espaço físico se fundamenta em uma correspondência entre o espaço físico e o espaço social $^{82}$, mas também de demonstrar que essa correspondência é um evento de longa duração, ou ainda oferece a possibilidade da verificação de eventuais mudanças ou de interrupções nessas tendências. Em suma, o método descritivo e cartográfico me parece valioso como uma ferramenta de análise diacrônica ou histórica de análise da

\footnotetext{
${ }^{79}$ Esta pesquisa não testa esses limites temporais da correspondência entre o espaço físico e o espaço social, pois a cidade de Goiânia não oferece tal possibilidade, já que a correspondência postulada pode ser observada desde o seu planejamento original, antes mesmo de sua fundação.

${ }^{80} \mathrm{Cf}$. Introdução desta dissertação.

${ }^{81}$ Cf. Villaça 2001, Hoyt 1939.

82 Já que os padrões de estruturação urbana descritos por Hoyt e Villaça me parecem ser correspondentes àqueles descritos por Bourdieu.
} 
configuração sócio-espacial, em uma cidade onde ocorre uma correspondência entre as divisões do espaço físico e as hierarquias sociais.

Por isso, acredito que as análises descritivas da estrutura física urbana podem ser uma ferramenta privilegiada para a análise da correspondência entre a estrutura física e a estrutura social, como indica a leitura de O Espaço Intra-Urbano no Brasil, de Flávio Villaça e como sugerem Mário Eufrásio em Estrutura Urbana e Ecologia Humana e Pierre Bourdieu em A Produção da Crença ${ }^{83}$.
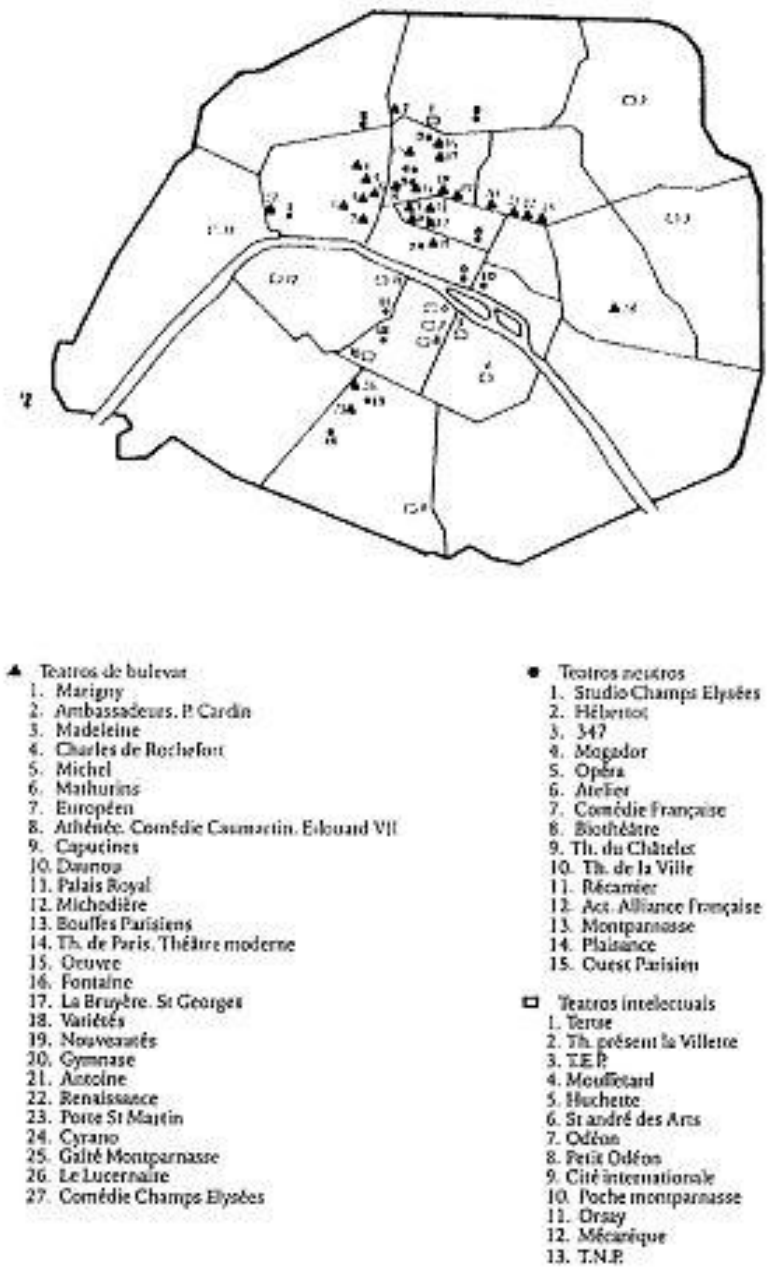

Figura 54. Mapa indicando teatros no espaço urbano de Paris. Os teatros estão classificados em três categorias. Trata-se da "planta da página 37" indicada na nota 83. Fonte: Bourdieu 2004.

83 "Estaríamos impedidos de compreender as propriedades mais específicas da concentração no espaço das lojas de luxo (a rue du fauburg Saint-Honoré e a rue Royale, ou, em Nova York, Madison Avenue e Fifth Avenue), se não observássemos, por um lado, que as diferentes classes de agentes e instituições que as constituem (por exemplo, os antiquários ou as galerias) ocupam posições homólogas em campos diferentes e, por outro, que o mercado com base local constituído pelo reagrupamento dessas instituições oferece sobre o conjunto dos bens (no caso em particular, o conjunto dos símbolos distintivos da classe) correspondentes a um sistema de preferências. Em suma, a representação cartográfica da distribuição de agentes e instituições constitui uma técnica de objetivação bastante poderosa com a condição de que se saiba ler na planta (da página 37) a relação construída entre a estrutura do sistema das posições constitutivas do espaço de um campo e a estrutura do espaço social, por sua vez, definido pela relação entre bens distribuídos no espaço e agentes definidos por capacidades desiguais de apropriação de tais bens" (Bourdieu 2004: 38). 
Cabe, então, elaborar a seguinte questão, denominada questão sociológica: como interpretar sociologicamente os dados obtidos a partir da pesquisa empírica? Em outras palavras, como defini-los em termos de efeitos de relações, arranjos ou processos de interação social?

\subsection{A hipótese de pesquisa}

Para proceder à explicação da questão sociológica, levanto a hipótese de pesquisa, de que há uma manutenção histórica, no período observado, de uma correspondência entre a estrutura física e a hierarquização social na cidade ${ }^{84}$. Essa hipótese resulta da aplicação do postulado da correspondência entre o espaço físico e o espaço social aos resultados da observação empírica, resultantes da aplicação do método descritivo de representação cartográfica da estrutura urbana.

Abaixo apresento dois exemplos do uso do método, com a plotagem de dados referentes a edificações verticais de alto padrão obtidos de fontes diversas, que irão mostrar como a aplicação do método levou à elaboração da hipótese de pesquisa. É preciso destacar que esses exemplos estão totalmente de acordo com a apresentação geral dos resultados do método, e estão ainda inseridos na representação dos setores de círculo "hoytianos", mostradas acima.

No primeiro exemplo, utilizamos os dados obtidos na ADEMI-GO para qualificar as novas edificações de alto padrão, em construção ou com seus projetos aprovados, consideradas "lançamentos" pela pesquisa realizada em dezembro de $2010^{85}$. Desses lançamentos, tomei apenas aqueles que apresentavam um preço para a venda superior a 4.000 reais por metro quadrado, o que, segundo informações obtidas de fontes ligadas ao mercado imobiliário, caracteriza os recentes empreendimentos

\footnotetext{
${ }^{84}$ Isso ocorre no local e no período histórico observado, o que não garante uma universalidade dessa lógica. É preciso lembrar que Goiânia foi uma cidade planejada na década de 30, no contexto histórico da "Marcha para o Oeste", na era Vargas. Portanto, Goiânia é fruto de um projeto de modernização (Cf. Chaul 1988). Além disso - e mais importante - em Goiânia a frente de expansão imobiliária se mantém ainda em progressão, suprida pela oferta de terras não urbanizadas disponíveis. Ao mesmo tempo, o "valor do clássico" ainda não é um valor apreciado pelo mercado imobiliário, como já acontece em cidades como o Rio de Janeiro e São Paulo. Desse modo, os processos conhecidos como "gentrificação" e "retorno ao centro", não são ainda significativos em Goiânia, embora as operações de "revitalização" já ocorram na cidade desde os anos 70, com o Projeto Cura (Cf. Mota 2004).

${ }^{85}$ A ADEMI-GO possui em seus arquivos dezenas dessas pesquisas, realizadas em períodos que variam de semestrais a trimestrais, e que cobrem as décadas de 90 e 2000.
} 
verticais de alto padrão ${ }^{86}$. Porém, se as pesquisas da ADEMI-GO fornecem o valor do metro quadrado dos lançamentos imobiliários regulares de Goiânia, além de outras informações importantes ${ }^{87}$, não consta na pesquisa o endereço dos lançamentos, mas apenas seus nomes. Por isso, tive de cruzar os dados obtidos na ADEMI-GO com uma pesquisa realizada na internet, visando encontrar o endereço de cada um desses lançamentos. Como os lançamentos de alto padrão são bem divulgados na internet, e quase todos contam com "hot-sites" ${ }^{\text {" } 88}$, foi tarefa relativamente fácil o levantamento de todos os endereços dos imóveis da pesquisa de dezembro de 2010 que apresentavam um valor por metro quadrado igual ou superior a 4.000 reais.

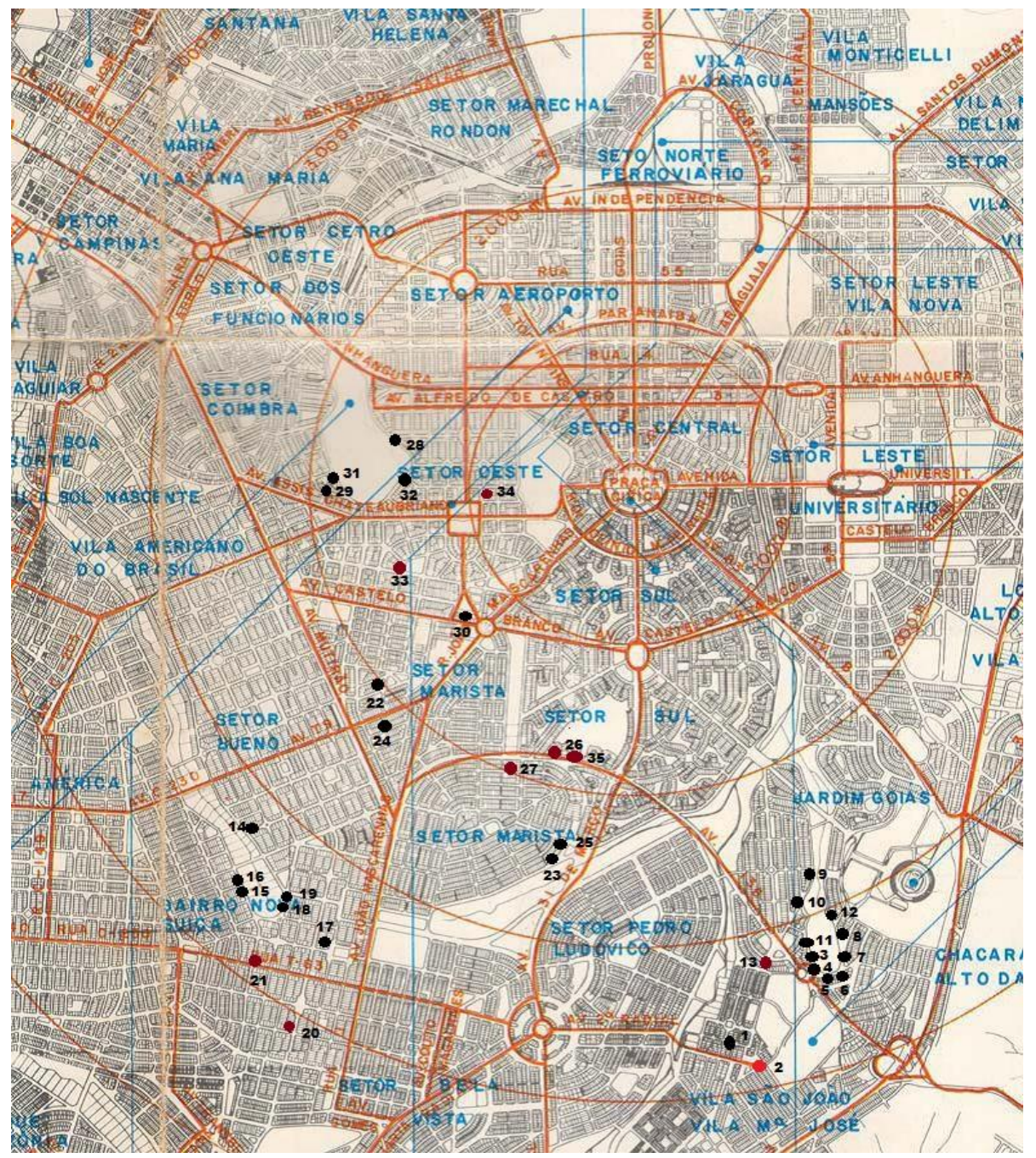

\footnotetext{
${ }^{86}$ Em entrevista publicada na Revista Painel em sua quinta edição (05/2011), o presidente da ADEMI-GO coloca o valor médio em Goiânia do metro quadrado de um lançamento residencial de alto padrão em torno de 4.000 reais. A Revista Painel é uma publicação do CRECI-GO, Conselho Regional de Corretores de Imóveis de Goiás.

${ }^{87}$ Tais como metragem, número de quartos, número de banheiros, número de vagas na garagem, estágio da construção, etc.

${ }^{88}$ Hot-sites são sites publicitários da internet, comumente utilizados no ramo imobiliário para apresentar lançamentos verticais residenciais e comerciais.
} 
Figura 55. Lançamentos imobiliários com o valor por metro quadrado acima de 4.000 reais, de acordo com a pesquisa da ADEMI-GO de dezembro de 2010. Em preto, lançamentos residenciais. Em vermelho, lançamentos comerciais. Em laranja, um lançamento de uso misto (2).

Obtidos os endereços dos lançamentos considerados de alto padrão, foi possível plotar os resultados em um mapa de fundo obtido na SEPLAM ${ }^{89}$. Em preto, foram representados os lançamentos residenciais de alto padrão. Em vermelho, os lançamentos de imóveis comerciais e em laranja, um único exemplar de uso misto. No total, foram plotados 34 lançamentos de alto padrão ${ }^{90}$ no mapa de fundo.

O exemplo seguinte foi resultado de uma pesquisa de sites de vendas de imóveis em Goiânia, com a observação de duas gerações de edificações residenciais verticais de alto padrão, construídas na cidade de Goiânia. Orientado pelas entrevistas gravadas que realizei com dois corretores imobiliários e com um avaliador de imóveis da Caixa Econômica Federal, atuantes na cidade de Goiânia, levantei os seguintes critérios para a qualificação dos edifícios das duas gerações: os edifícios da primeira das duas gerações arquitetônicas em pauta, construídos nas décadas de 80 e 90, teriam de apresentar um valor de venda igual ou superior a 700.000 reais, e deveriam possuir no mínimo quatro quartos, sendo três suítes e sem contar os quartos de empregados. Os edifícios da segunda geração arquitetônica em questão, construídos nos anos 2000, teriam de apresentar um valor de venda igual ou superior a 800.000 reais, e apresentar no mínimo quatro suítes.

Informações acerca da metragem tiveram de ser deixadas de lado, tendo em vista a dificuldade de obtenção dessas metragens na internet. Além disso, a datação, na internet, dos edifícios da primeira das gerações, foi difícil de ser realizada, pois na maioria dos casos a informação padrão era "mais de vinte anos", ou "mais de dez anos". Alguns casos puderam ser confirmados pela análise de fotografias disponíveis nos sites, cruzadas com tomadas de fotografias em campo e com informações solicitadas a porteiros, além de consultas informais com antigos moradores da cidade. Apenas os

\footnotetext{
${ }^{89}$ Secretaria Municipal do Planejamento de Goiânia.

90 É preciso notar que uso do valor de 4.000 reais por metro quadrado em 2010 para edificações classificadas como comerciais na pesquisa da ADEMI é arbitrária, pois os valores do metro quadrado para uso comercial em Goiânia foram considerados pelos corretores entrevistados como sendo, de um modo geral, ligeiramente superiores aos valores do metro quadrado de salas comerciais, o que é confirmado pela análise dos valores médios por bairro, comerciais e residenciais, disponíveis nos arquivos da ADEMI. No entanto, o uso do valor de 4.000 reais foi o suficiente para excluir aqueles lançamentos comerciais constantes na pesquisa e situados no Centro Empresarial de Aparecida de Goiânia, no município de Aparecida de Goiânia, conurbado com o município de Goiânia, e localizado ao sul, em áreas periféricas ao setor de alto padrão.
} 
casos cuja datação parece segura ${ }^{91}$, pela caracterização morfológica dos edifícios a confirmar a datação imprecisa dos sites e dos depoentes consultados, foram plotados no mapa de fundo.

Assim, os edifícios de alto padrão construídos nas décadas de 80 e 90 foram plotados em vermelho, e os construídos recentemente ou em construção em preto. $\mathrm{O}$ número ao lado dos pontos representa a quantidade de quartos no caso da primeira geração, e o número de suítes no caso da segunda geração.

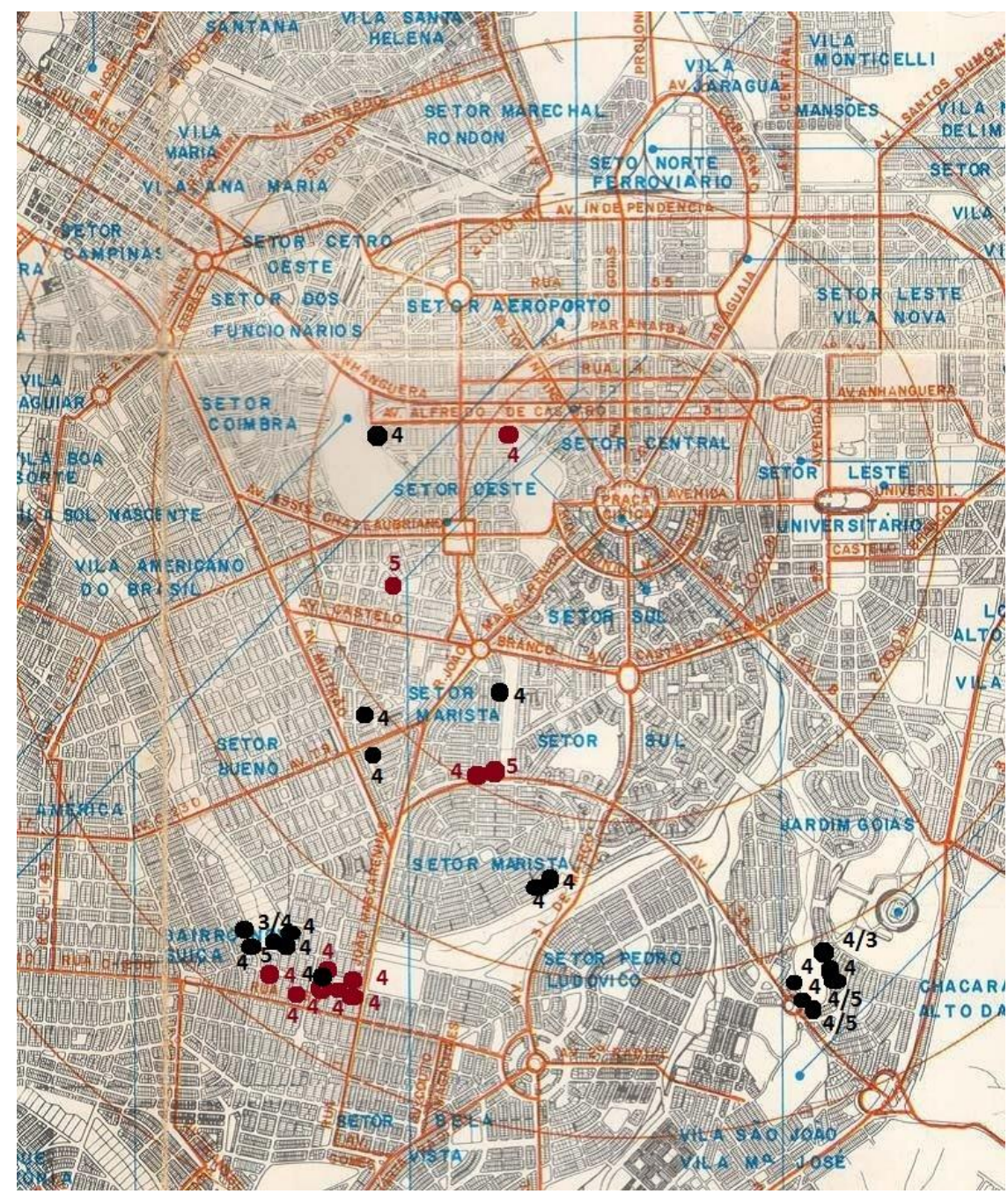

Figura 56. Apartamentos residenciais de alto padrão à venda, encontrados em sites de ofertas de imóveis. Em vermelho, apartamentos em prédios construídos nas décadas de 80 e 90 . Em preto, apartamentos em prédios construídos na década de 2000. Alguns edifícios de construção recente apresentam dois números de suítes por oferecerem diferentes projetos de apartamentos seriados, conforme tendência em voga atualmente.

Os resultados de pesquisa, referentes a uma amostra significativa ${ }^{92}$, mostram três tendências de concentração das edificações verticais de alto padrão. Em primeiro

${ }^{91}$ Em referência ao edifício ter sido construído de fato entre as décadas de 80 e 90. 
lugar, há uma concentração dessas edificações na parte central da cidade, em um raio que não ultrapassa os quatro quilômetros do núcleo central original da cidade, como se nota pelos círculos concêntricos traçados no mapa de fundo a cada quilômetro a partir do Centro Cívico de Goiânia. Em segundo lugar, os imóveis mais distantes do centro original se desenvolvem apenas para o sul, e a área mais recente de concentração de edifícios verticais de alto padrão se encontra a sudeste da cidade, em um local onde não existem edificações verticais de alto padrão construídas nas décadas de 80 e 90 . Em terceiro lugar, vê-se que os edifícios residenciais de alto padrão, próximos ao centro original, situados fora da periferia, e ainda projetados para o sul, não se dispõem em uma área homogênea de concentração, mas sim na forma de núcleos e faixas de imóveis verticais de alto padrão. Salvo uma única exceção ${ }^{93}$, todos os imóveis representados nos dois mapas de unidades urbanas podem ser associados a concentrações uso e de valor que se encontram dispostas em torno de parques, praças e vias. Essas concentrações são identificáveis em observações de campo, em fotografias aéreas, em relatos, em fontes bibliográficas ou da imprensa. Os núcleos são formados por concentrações de edificações ao redor de praças, parques, ou de grandes equipamentos urbanos, como shopping centers, enquanto as faixas se dispõem ao longo de ruas e avenidas.

As três tendências de concentração dos imóveis residenciais verticais de alto padrão mostradas acima são as mesmas apontadas na apresentação dos resultados gerais da aplicação do método descritivo e cartográfico. Elas correspondem às três escalas de classificação dos elementos urbanos representadas pelos modelos de Burgess, Hoyt e Griffin e Preston. Portanto, essas três escalas dos padrões de segregação urbana são verificáveis, na medida em que os usos do solo de alto padrão estão concentrados nas áreas centrais da cidade, em um setor de mais altas rendas que se expandiu historicamente em direção ao sul, e com a ocorrência de núcleos e faixas de atividades de alto padrão internas a esse setor.

\footnotetext{
92 A pesquisa da ADEMI compila dados dos lançamentos imobiliários verticais da grande maioria das empresas construtoras regulares que operam em Goiânia e Aparecida de Goiânia. Ao que nos parece, no caso das edificações de alto padrão, todas ou praticamente todas as unidades são registradas nessas pesquisas. Assim, a figura 1 apresenta um quadro bem completo dos lançamentos imobiliários verticais recentes, com o valor do metro quadrado para venda igual ou superior a 4.000 reais. No caso da figura 2 , o registro é mais parcial, pois reflete uma pesquisa de ofertas encontradas em sites imobiliários, muitas das quais tiveram de ser excluídas por falta de dados.

${ }^{93}$ Estamos nos referindo à edificação de número 20, da figura 1. Trata-se de um lançamento comercial que estaria excluído de nossa lista se aplicássemos o critério já sugerido da aplicação de um valor médio do metro quadrado ligeiramente superior ao do valor residencial, para a qualificação das edificações comerciais de alto padrão.
} 
Uma afirmação, decorrente da adaptação e aplicação do método descritivo e cartográfico de representação da estrutura urbana ao caso de Goiânia, pode ser expressa nos seguintes termos: existe um mesmo padrão de segregação que evoluiu ao longo de toda a história da cidade. Ou melhor: há um padrão de segregação sócio-espacial e um padrão geral de crescimento das áreas segregadas de alto padrão que atravessa toda a história da cidade.

As três escalas de estruturação de imóveis de alto padrão mostradas pelos exemplos dos edifícios residenciais de alto padrão também correspondem a três escalas de observação de padrões de segregação sócio-espacial, dado o postulado da correspondência entre o espaço físico e o espaço social. Pode-se supor, com a aplicação do postulado de partida aos resultados da aplicação do método cartográfico e descritivo, que um mesmo padrão de segregação sócio-espacial evoluiu conforme a cidade cresceu.

Aqui se apresenta a hipótese de pesquisa, que pode ser formulada nos seguintes termos: um processo histórico e específico de segregação sócio-espacial pode ser representado pelo método descritivo e cartográfico porque há, ao menos no tempo e espaço estudados, uma correspondência entre o espaço físico e o espaço social.

\section{A explicação da hipótese de pesquisa}

Como foi posto acima, a questão sociológica levantada é a de como interpretar sociologicamente os dados obtidos pela aplicação do método de descrição da estrutura urbana empregado. Como a aplicação do postulado de partida aos resultados empíricos resultou em uma hipótese de pesquisa, a questão sociológica pode ser assim desenvolvida: como se explica a hipótese de pesquisa, de que um processo histórico e específico de segregação sócio-espacial pode ser representado pelo método descritivo e cartográfico porque há uma correspondência entre o espaço físico e o espaço social?

Para proceder à explicação da hipótese de pesquisa, foram desenvolvidas respectivamente cinco questões, denominadas questões de pesquisa. A cada uma das questões de pesquisa corresponde um passo para a explicação da hipótese da pesquisa e um conjunto de categorias de análise que serão as ferramentas utilizadas em cada um dos procedimentos de análise que irão configurar o método sociológico a ser apresentado como resultado final da pesquisa. Por isso, a conclusão da pesquisa irá corresponder a uma explicação geral da hipótese de pesquisa, formulada como uma 
nova hipótese, a hipótese final, que deverá ser testada a posteriori pela aplicação de um novo método, o método sociológico de análise da dominação do espaço urbano, que também será apresentado na conclusão desta pesquisa.

\subsection{Algumas noções de Bourdieu}

Aqui se faz necessária uma apresentação de algumas noções de Bourdieu já referidas anteriormente, mas que, nesse ponto, levam a um entendimento específico acerca da dominação do espaço urbano.

Embora esta pesquisa não se atenha a uma análise e a um uso acurado das noções de Pierre Bourdieu, e tampouco a uma análise das mudanças conceituais em sua biografia, ela fará uso de algumas categorias desse autor, tomadas da leitura de $A$ Distinção, Coisas Ditas, As Regras da Arte, A Miséria do Mundo e Meditações Pascalianas, obras originalmente publicadas em 1979, 1987, 1992, 1993 e 1997, respectivamente. Também destacamos A Produção da Crença, edição brasileira que reúne três artigos do final da década de 70, e A Economia das Trocas simbólicas, coletânea organizada por Sergio Miceli. O ponto de vista desta pesquisa, que lida com a ocupação do espaço urbano e com a classificação dos diversos elementos que se situam nesse espaço, enfatiza o uso das noções de "espaço social" e de "campo do poder", conforme encontradas nessas obras destacadas e em outros trabalhos pesquisados. Entende-se o "espaço social" como um "campo" geral em que se distribuem "campos" sociais específicos, e o "campo do poder" como o "campo" envolvente dos detentores de capitais ou recursos dominantes, políticos e econômicos.

A noção bourdieana de "campo" foi considerada por Sergio Miceli uma "noção-chave", ao lado da noção de "habitus" (Miceli, 2003: 63). A noção de campo "foi tomando corpo no intuito de nomear essa nova amplitude de perspectivas sobre a sucessão de experimentos históricos que estão na origem das feições da cultura erudita na moderna sociedade capitalista" (idem: 24). O campo "constituía, então, um ponto de vista do qual se podia captar posições produtoras de visões, obras e tomadas de posição, a que correspondiam classes de agentes providos de propriedades distintivas, portadores de um habitus, também socialmente constituído" (ibid.: 65). De acordo com Miceli, em suas obras iniciais, Bourdieu estava empenhado em "qualificar a situação de dependência material e política dos intelectuais e artistas em relação aos grupos e frações dirigentes", o que o leva a um ponto de vista em que "tudo se passa como se as 
obras e as tomadas de posição estéticas dos agentes pertencentes a quaisquer vertentes do campo intelectual se situassem num gradiente de dominação-subordinação, contrastando os produtores culturais mais dependentes aos mais autônomos perante os detentores do poder econômico e político" (ibid.).

Ainda de acordo com Miceli, em trabalhos posteriores de Bourdieu, o conceito de "habitus" e o conceito de "campo" são desenvolvidos. Os habitus aparecem como "sistemas de disposições duráveis" que operam como "princípios de geração de práticas" (ibid.: 70). Desse modo, "a prática emergia como algo justificado em decorrência do seu contexto e, ao mesmo tempo, como uma conduta dotada de certa autonomia em relação à situação de ocorrência, ou melhor, como o produto de uma relação dialética entre um contexto e um habitus, uma conduta resultante de uma matriz de percepções, apreciações e outras ações, que se esgueira em meio às constrições sem se deixar determinar completamente pelas mesmas". (ibid.: 70-71). Assim, "o habitus estaria na raiz das possibilidades de apreensão dessa matriz de práticas de um grupo ou de uma classe, assimilável ao que Bourdieu define como lei imanente, internalizada por cada agente por meio de sua primeira educação". (ibid.: 71). Já o "campo", "equivale a uma estrutura de trocas sociais, dependente de disposições que fazem operar o sistema simbólico que lhe é inerente, ajustado às regras que o definem e que se impõem aos agentes com a força de um constrangimento lógico e social, ou seja, da ordem de uma experiência vivida e reconhecida pelos agentes como prenhe de sentido e significação conforme os princípios daquele universo de exceção regrada". (ibid:: 72-73). O campo, de acordo com Miceli, "pode ser, portanto, exemplificado como uma 'forma de vida', ou seja, um espaço social acoplado a um sistema simbólico”. (ibid.: 73). De acordo com Miceli, na análise da obra de Flaubert por Bourdieu, "emerge a illusio [crença], o investimento no jogo, como o princípio de funcionamento de todos os campos sociais". (ibid.: 77). Essa constatação leva Miceli a concluir que "O campo constitui o instrumento por excelência, por meio do qual se procede ao progressivo reconhecimento histórico dos processos que estão na raiz da gênese e desenvolvimento das atividades culturais nas modernas sociedades capitalistas", e que "O conceito de campo deveria ainda permitir um resgate dos fundamentos capazes de esclarecer a illusio como forma espraiada de crença num dado espaço de sociabilidade, ao recuperar os sentidos do envolvimento de todos nós com o jogo no qual nos lançamos por inteiro, rendidos, incondicionalmente". (ibid.: 77-78). 
Se para Miceli o "campo" pode ser exemplificado como um espaço social acoplado a um sistema simbólico, então devemos evitar tomar o conceito de uma forma rígida, pois um “campo" pode ser específico, como o "campo literário", ou abrangente a todo um conjunto de "campos", abrigando-os em seu interior, como o "espaço social (nacional)", conforme mapeado por Bourdieu em As Regras da Arte (Bourdieu 2002: 144), que se refere ao posicionamento do campo de produção cultural parisiense no tempo de Flaubert e Baudelaire, situado no interior de um espaço social mais abrangente. Nessa ilustração, o autor insere dentro do "espaço social" o "campo do poder", dentro do "campo do poder" o "campo de produção cultural" e "dentro do campo da produção cultural" o "subcampo da produção restrita". Em As Regras da Arte, a noção de "espaço social”, embora não seja colocada de forma unívoca ou rígida, muitas vezes indica um espaço de posições sociais global, como no caso referido e como no momento em que o autor utiliza o termo "campo social global" com esse mesmo sentido de "espaço social", como um campo ou espaço social abrangente. O autor se expressa dessa forma ao discorrer sobre o fato de que a "homologia entre as posições no campo literário (etc.) e as posições no campo social global" nunca é "tão perfeita quanto aquela que se estabelece entre o campo literário e o campo do poder onde se recruta, na maior parte do tempo, sua clientela" (Bourdieu, 2002: 284). Nessa passagem, o "campo social global” está apresentado como o "espaço social” que contém o "campo literário" e o "campo do poder". É com base nesse sentido de "espaço social", que Bourdieu afirma que "Toda trajetória social deve ser compreendida como uma maneira singular de percorrer o espaço social". (idem: 292).

Em Coisas ditas, Bourdieu apresenta sua metáfora espacial com a definição de "espaço social":

É possível (...) comparar o espaço social a um espaço geográfico no interior do qual se recortam regiões. Mas esse espaço é construído de tal maneira que, quanto mais próximos estiverem os grupos ou instituições ali situados, mais propriedades eles terão em comum; quanto mais afastados, menos propriedades em comum eles terão. As distâncias espaciais - no papel - coincidem com as distâncias sociais. Isso não acontece no espaço real. Embora se observe em todos os lugares uma tendência para a segregação no espaço, as pessoas próximas no espaço social tendem a se encontrar próximas - por opção ou por força - no espaço geográfico, as pessoas muito afastadas no espaço social podem se encontrar, entrar em interação, ao menos por um breve período de tempo e por intermitência, no espaço físico. (Bourdieu 2004-b:153). 


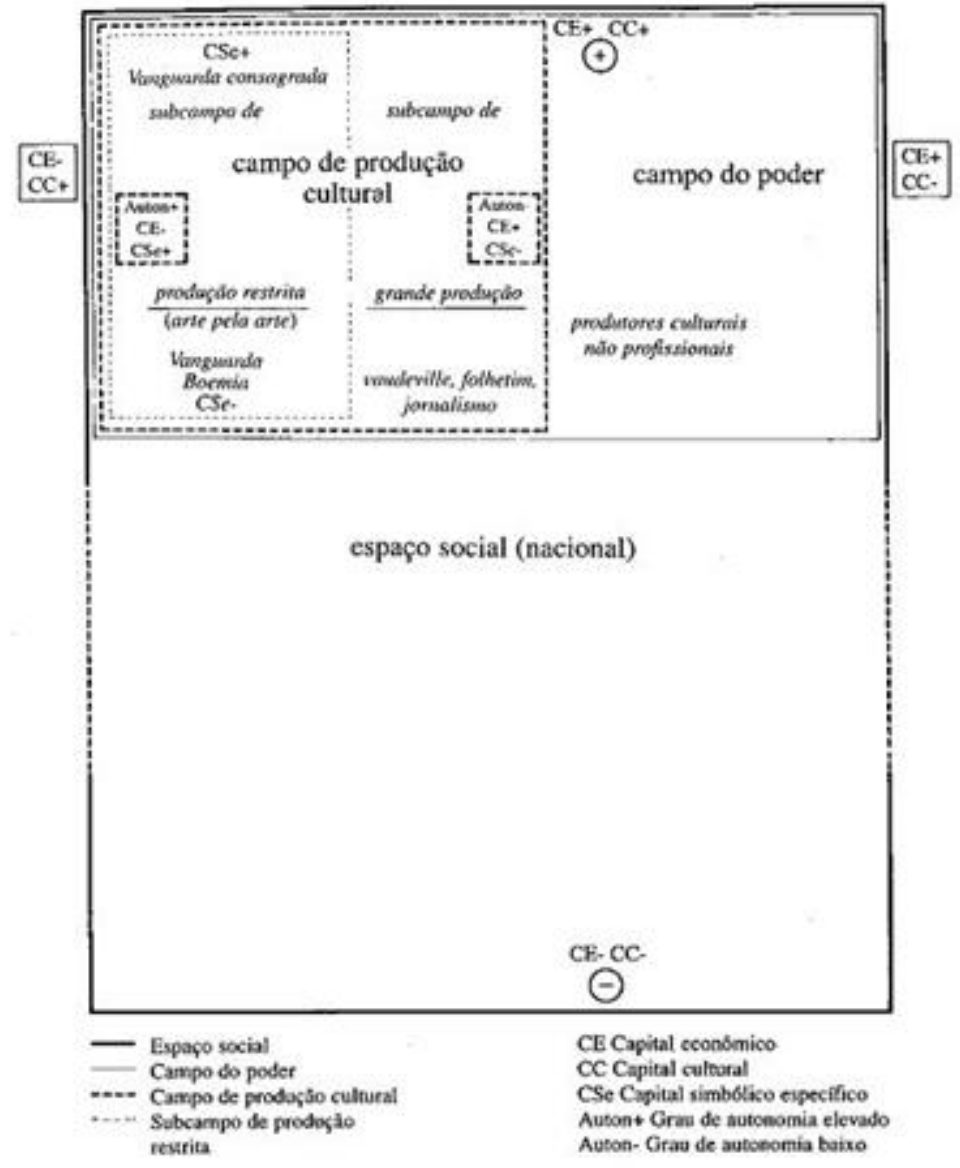

Figura 57. Representação do espaço social em As Regras da Arte. O campo do poder está inserido no espaço social e o campo de produção cultural está inserido no campo do poder. Fonte: Bourdieu 2002.

Esse referencial levou esta pesquisa à adoção de uma noção maleável de "espaço social", como uma noção que pode denominar tanto um campo específico como o "campo literário", um campo dominante que influencia outros campos, como o "campo do poder", ou ainda um espaço social mais abrangente, como o "espaço social" nacional. Tomando as noções de "campo" e de "espaço social” dessa forma maleável, é possível dizer que os campos sociais são situados em um espaço social global e que, enquanto espaços de posições sociais qualificadas que estão em disputa, são também campos de poder, ainda que mais ou menos subordinados a um campo de poder mais abrangente, o campo do poder propriamente dito.

De acordo com Miceli, a partir da década de 70, Bourdieu renomeia o "sistema de poder" como "campo de poder", buscando relacionar os domínios mais específicos do espaço social à "estrutura da classe dirigente". (Miceli, 2003: 64). É importante notar que o "campo do poder", definido como "o espaço das relações de força entre agentes e 
instituições que têm em comum possuir o capital necessário para ocupar posições dominantes nos diferentes campos (econômico e cultural, especialmente)" (Bourdieu, 2002: 244), é um pólo de referência na constituição interna do campo mais específico da produção cultural. Isso porque "Em razão da hierarquia que se estabelece nas relações entre as diferentes espécies de capital e seus detentores", os campos de produção cultural "ocupam uma posição dominada, temporalmente, no seio do campo do poder. Por mais livres que possam estar das sujeições e das solicitações externas, são atravessados pela necessidade dos campos mais abrangentes, a do lucro, econômico ou político" (idem: 245-246).

A autonomia do campo de produção cultural pode ser aferida pela predominância do reconhecimento atribuído aos detentores do capital cultural específico ou pela predominância do reconhecimento atribuído aos detentores dos capitais político e econômico referentes ao campo do poder:

\footnotetext{
Segundo o princípio de hierarquização externa, que está em vigor nas regiões temporalmente dominantes do campo do poder (e também no campo econômico), ou seja, segundo o critério do êxito temporal medido por índices de sucesso comercial (tais como a tiragem dos livros, o numero de representações das peças de teatro etc.) ou de notoriedade social (como as condecorações, os cargos etc.), a primazia cabe aos artistas (etc.) conhecidos e reconhecidos pelo 'grande publico'. O princípio de hierarquização interna, isto é, o grau de consagração especifica, favorece os artistas (etc.) conhecidos e reconhecidos por seus pares e unicamente por eles (pelo menos na fase inicial de seu trabalho) e que devem, pelo menos negativamente, seu prestígio ao fato de que não concedem nada à demanda (ibid:: 246247).

Pode-se pensar que um princípio similar de hierarquização se dá por correspondência na estrutura urbana. O campo do poder, onde se confere a primazia ao poder político e ao poder econômico, pode ser representado no espaço físico da cidade sob a forma de áreas consideradas de alto padrão, que são ocupadas justamente pelos agentes situados nas posições dominantes de cada campo específico e, em particular, os agentes mais dotados de capital político e de capital financeiro. Nesse sentido, as áreas de alto padrão são as áreas dominantes de uma cidade.
}

\subsection{A primeira questão de pesquisa}

Se um processo de segregação sócio-espacial pode ser representado pelo método descritivo devido a uma correspondência entre o espaço físico e o espaço social, a primeira questão que se levanta é a de como se dá essa correspondência. Assim, a primeira questão de pesquisa pode ser expressa da seguinte maneira: como se dá a 
correspondência entre o espaço físico e o espaço social? A resposta para essa questão se dá com base nas noções de moda e distinção.

Em Goiânia, como também observado nas pesquisas de Villaça e Hoyt, as concentrações de imóveis de alto padrão avançaram em uma direção específica, deixando para trás um rastro de obsolescência ${ }^{94}$ correspondente ao "declínio" dos "centros velhos" das cidades brasileiras, que passaram a ser ocupados por atividades comerciais de padrão inferior e por um público de classificação social inferior àquele que o utilizava em períodos anteriores (Villaça 2001: 271). Como então explicar essa sucessão de lançamentos imobiliários de alto padrão ao longo da história da cidade? Essa perspectiva levou ao interesse pelas considerações de Georg Simmel sobre a $\operatorname{moda}^{95}$.

Em seu ensaio sobre a moda, Simmel coloca que as necessidades humanas imanentes ${ }^{96}$ de imitação e de diferenciação concorrem para moldar esferas da vida social $^{97}$. Essas necessidades de "receptividade e atividade" são à primeira vista contraditórias, mas se complementam (1998:161). A moda, além disso, é uma manifestação específica dessas duas tendências, de modo que outras manifestações similares podem ocorrer em outras esferas sociais ${ }^{98}$. Por sua vez, em A Economia das Trocas Simbólicas, Bourdieu desenvolve uma linha de raciocínio que busca relacionar elementos simbólicos com as distinções econômicas entre os indivíduos da sociedade:

\footnotetext{
${ }^{94}$ Embora esse rastro seja tímido e o padrão de desenvolvimento das áreas de imóveis de alto padrão indique um crescimento maior do que um deslocamento. No entanto, a obsolescência dos imóveis, particularmente antigos imóveis residenciais de alto padrão, é notável em áreas de verticalização, mesmo quando há um aumento do valor monetário do terreno ocupado, e o valor geral dos terrenos do Setor Central da cidade, onde se situa o antigo centro planejado, é atualmente inferior ao valor geral dos terrenos dos setores situados mais adiante no eixo de expansão dos imóveis de alto padrão de Goiânia, como mostram as pesquisas de mercado da ADEMI e do CRECI-GO.

${ }^{95}$ Uma conhecida referência nos estudos urbanos é o texto de Simmel, de 1903, A Metrópole e a Vida Mental. Ali o autor alemão compara o cidadão metropolitano blasé com o rude aldeão, indicando as mudanças que o alto volume de comunicação cotidiana na metrópole provoca nas pessoas, estimulando novos padrões de pensamento e atitude, e uma mudança na personalidade: "Tal investigação deve responder à pergunta de como a personalidade se acomoda nos ajustamentos às forças externas. Esta é minha tarefa de hoje" (Simmel 1967: 16). Mas foi a leitura do ensaio sobre a moda de Simmel e a leitura de A Economia das Trocas Simbólicas, de Bourdieu, que nos levou à conexão entre os dois autores.

96 "O fundamento fisiológico do nosso ser, que aponta para a mudança de repouso e movimento e de receptividade e atividade, contém, com isso, também o modelo do nosso desenvolvimento espiritual" (Simmel 1998: 161).

97 "A peculiaridade da forma social 'moda' seria justamente atender, simultaneamente, a essas duas necessidades. A necessidade de apoio social é atendida na medida em que a moda é imitação e na 'imitação o grupo carrega o indivíduo'. A necessidade de singularidade, por sua vez, é atendida, posto que a moda é diferenciação e retira sua eficácia precisamente da possibilidade de distinguir entre indivíduos e classes. Já no fato de que toda moda é uma moda de classes, aproximando alguns de modo a distingui-los de outros, encontra-se essa mistura entre imitação e especificidade” (Souza 1998: 19).

98 "A moda é uma forma peculiar dentre aquelas formas de vida, por meio das quais se procura produzir um compromisso entre a tendência para a igualdade social e a tendência para marcar a distinção social" (Simmel 1998: 161).
} 
Vale dizer, as diferenças propriamente econômicas são duplicadas pelas distinções simbólicas na maneira de usufruir estes bens, ou melhor, através do consumo simbólico (ou ostentatório) que transmuta os bens em signos, as diferenças de fato em distinções significantes (...). De fato, nada mais falso que acreditar que as ações simbólicas (ou o aspecto simbólico das ações) nada significam além delas mesmas: na verdade, elas exprimem sempre a posição social segundo uma lógica que é a mesma da estrutura social, a lógica da distinção. (Bourdieu 2005: 16-17).

É a assumida inspiração simmeliana para a concepção de uma lógica da distinção por Bourdieu que conecta este autor a Simmel. A lógica da distinção se expressa, de acordo com Bourdieu, em processos circulares do tipo descrito por Simmel no ensaio sobre a moda ${ }^{99}$. A transmutação de bens em signos se faz com base em uma "homologia de estrutura entre o campo da produção ideológica e o campo da luta de classes", produzindo "formas eufemizadas das lutas econômicas" em função de impor, de forma "mascarada", uma "apreensão da ordem estabelecida como natural" que confere às relações de poder vigentes uma "aparência legítima (idem: 13-14).

À luz dessas leituras, é possível observar algumas colocações de Hoyt acerca da tendência de progressão observada nas áreas residenciais de alto padrão norteamericanas de sua época:

As vizinhanças residenciais de alta renda ou de alto padrão devem quase necessariamente se mover para fora, em direção à periferia da cidade. Os ricos raramente revertem seus passos e se movem para a retaguarda, para as casas obsoletas de que estão desistindo. De cada lado deles há geralmente uma área de renda intermediária, então eles não podem se mover para os lados. Como eles representam o grupo de renda mais alta, não há casas de melhor padrão abandonadas por outros grupos. Eles precisam construir casas novas em terrenos vagos. Geralmente esses terrenos estão disponíveis logo adiante da linha de deslocamento porque os promotores imobiliários, antecipando a tendência do crescimento elegante, os restringem para uso de alto padrão ou os especuladores estabelecem um valor do solo muito elevado para grupos de baixa renda ou de renda intermediária. Assim, a tendência natural do deslocamento da área de alta renda é para fora, em direção à periferia da cidade, no mesmo setor de onde partiu o movimento. A exceção a este movimento para adiante é o desenvolvimento de áreas de apartamentos de luxo em antigas áreas residenciais (Hoyt 1939: 116; grifos meus). ${ }^{100}$

99 “Como observa Simmel, a moda do vestuário é um processo que combina a individualização e a imitação que - a exemplo do Sich-gleich-machen (igualar-se) hegeliano - exprime de modo paradoxal a vontade de afirmar a particularidade pela busca da diferença última. E Simmel observa ainda que a moda, porque permite marcar simbolicamente 'a distinção' pela possibilidade de adotar sucessivamente diferentes signos distintivos, obedece a uma lógica semelhante à da honra (pelo menos a que se observa nas sociedades estratificadas), na medida em que também confere uma marca comum aos membros de um grupo particular, distinguindo-os dos estranhos ao grupo" (Bourdieu 2005: 18).

100“'High rent or high grade residential neighborhoods must almost necessarily move outward toward the periphery of the city. The wealthy seldom reverse their steps and move backward into the obsolete houses which they are giving up. On each side of them is usually an intermediate rental area, so they cannot move sideways. As they represent the highest income group, there are no houses above them abandoned by another group. They must build new houses on vacant land. Usually this vacant land lies available just ahead of the line of march of the area because, anticipating the trend of fashionable growth, land promoters have either restricted it to high grade use or speculators have placed a value on the land that is too high for the low rent or intermediate rental group. Hence the natural trend of high rent area is outward, toward the periphery of the city in the very sector in which the high rent area started. The 
Essa passagem, entendida sob o ponto de vista da lógica da moda e da distinção, conduz a uma primeira compreensão acerca das motivações de uma demanda para a produção sempre renovada de áreas residenciais elegantes em um eixo que se mantém na mesma direção geral, evitando áreas "menos distintas". Assim, os ricos, que de acordo com Hoyt "devem quase necessariamente se mover para fora", "raramente revertem seus passos" e "precisam construir casas novas em terrenos vagos", são os protagonistas privilegiados de uma "corrida residencial" "101 que demanda uma produção contínua de novas residências ao longo de um eixo e cada vez mais distantes do "CBD", de um modo similar à dinâmica da moda descrita por Simmel:

(...) a nova moda, diz respeito, em todas as suas manifestações, apenas aos estamentos superiores. Estes se apartam, desse modo, dos estamentos inferiores, ressaltando a igualdade dos seus componentes e, simultaneamente, a distinção em relação aos que se situam abaixo. Tão logo estes últimos começam a apropriar-se da moda - precisamente porque eles olham e se orientam sempre para cima (...) reagem os estamentos superiores com o abandono da mesma e a pronta inclinação para uma nova moda (...) (Simmel 1998: 163).

Cada estilo arquitetônico, cada padrão reconhecido de equipamentos e instalações, na medida em que se populariza, torna-se por isso mesmo obsoleto e não mais cumpre sua função de aproximar os ricos e excluir os não-ricos. A mesma lógica também poderia transparecer na atração exercida pela área residencial elegante sobre outras áreas residenciais, que tendem a se dispor em setores adjacentes ao eixo de deslocamento das residências elegantes, já que os "estamentos inferiores" sempre "se orientam para cima".

exception to this outward movement is the development of de luxe apartment areas in old residential areas".

${ }^{101}$ Como exemplo de "corrida residencial", em um estudo sobre os imigrantes judeus em Nova Iorque, Heinze (2004) coloca que: "De acordo com a idéia de que os luxos podem ser regularmente convertidos em necessidades, os recém-chegados se encontraram envolvidos no que parecia ser um ciclo interminável de aquisição". O autor descreve a inserção dos imigrantes nesse ciclo de aquisição, como se segue nessa relevante passagem: "No início dos anos de 1890, muitos judeus recém-chegados viviam em pequenos apartamentos 'quarto e sala' alugados por oito ou dez dólares ao mês. Um imóvel de três cômodos em um edifício moderno era um luxo distinto. Mas, dentro de poucos anos, muitos dos velhos prédios de aluguel foram demolidos, e os recém-chegados se acostumaram com apartamentos de quatro ou cinco cômodos com mais conveniências. Na medida em que o passo da modernização se acelerava, os aluguéis se elevavam, mas a oferta foi preenchida pela demanda de recém-chegados que entravam no ciclo de gostos ascendentes. Por volta de 1902, houve um surto de construção de edifícios com apartamentos de cinco ou seis cômodos com as últimas conveniências. Os banheiros se tornaram um lugar-comum, e a eletricidade e os elevadores não eram incomuns. (...). O fenômeno de expectativas continuamente crescentes foi oficialmente documentado pelo departamento de casas de aluguel da cidade de Nova Iorque, que reportou que, em 1914, a cidade abrigava em torno de 1.500 .000 imóveis de aluguel em mais de 22.000 edifícios construídos desde a aprovação da New York Tenement House Law em 1901, que requeria muito mais iluminação e ventilação, e um banheiro dentro de cada apartamento. Com a (...) pressão da demanda de consumidores por melhor moradia, os padrões de 1900 se tornaram ultrapassados por volta do final da década" (Heinze 2004: 66-67). 
Com isso é possível supor que uma dinâmica contínua de segregação sócioespacial tenha afetado os padrões de estruturação urbana que podem ser observados empiricamente. Se, como afirma Bourdieu, os agentes são classificados em relação à sua posição social, e se o espaço urbano tem a propriedade de aproximar e excluir os agentes em relação às suas posições sociais, então é possível supor que a lógica da distinção dos agentes exerce efeitos sobre a estrutura urbana. Um desses efeitos pode ser justamente o processo de deslocamento ou expansão dos usos do solo residenciais e centrais de alto padrão, conforme descrito por Villaça e conforme observado em Goiânia.

A classificação dos objetos que ocupam o espaço ganha importância nesse ponto, pois se é possível delimitá-los em diferentes escalas de associação e comparar essas classificações, pode ser possível tentar associá-los a fontes que dizem respeito a seu papel simbólico, relacionado à capacidade de atribuir distinção aos agentes que deles se apropriam, e de naturalizar essas mesmas posições distintas do espaço social. Também é possível supor que o que se assemelha nas estruturas são suas diferenças e semelhanças, seus padrões de diferenciação e associação, que são ainda padrões de aproximação e de distanciamento. Todas essas disposições são operadas pelos agentes que produzem, se apropriam e utilizam o espaço urbanizado.

É possível aqui apresentar uma resposta para a primeira questão de pesquisa: $A$ correspondência entre a estrutura social e a estrutura urbana se faz com base na qualificação social da distribuição dos objetos e agentes que compõem essa estrutura física ou que nela se dispõem, e que está relacionada com as hierarquias sociais dos agentes. A conexão entre a distribuição socialmente qualificada das unidades e as hierarquias sociais se dá pela lógica da distinção, com base na exclusão e aproximação dos agentes em relação à sua distância ou proximidade das unidades, o que permite que essas unidades sejam utilizadas como signos distintivos. Em suma: as unidades da estrutura urbana - incluindo os agentes - distinguem os agentes. Por essa propriedade de distinção, as unidades da estrutura urbana podem corresponder à posição dos agentes no espaço social.

\subsection{A segunda questão de pesquisa}

Se o espaço físico abriga o espaço social e se os agentes podem ser qualificados em relação aos imóveis que ocupam, então é importante se ater aos 
critérios que orientam tais classificações. Essa atenção leva a segunda questão de pesquisa a ser expressa nos seguintes termos:

Como as características dos agentes e objetos podem ser classificadas de modo a atribuir propriedades simbólicas de distinção aos agentes? Ou ainda: como se dá a distinção dos agentes pelas unidades da estrutura urbana?

\subsubsection{Os critérios e os esquemas de qualificação}

Sob uma orientação teórica que aponta para a distinção e a moda, foi possível realizar uma interpretação das observações empíricas acerca da configuração urbana de Goiânia. Ficou claro que os padrões de disposição dos imóveis encontrados pareciam de fato estar ligados às suas qualidades atribuídas em esquemas diversos de classificação. Esquemas diversos de classificação, tais como os planos iniciais da cidade, os mapas de valor do imposto territorial urbano, os manuais de avaliação imobiliária ou mesmo os clichês da propaganda imobiliária e as informações padronizadas de anúncios em sites e sessões de classificados, correspondem de um modo geral ao valor solo do urbano e à qualidade dos imóveis em relação ao valor do terreno. Surgiram então questões relacionadas à constituição do valor social atribuído aos imóveis e sua conexão com o valor financeiro, expressa na associação dos "mais altos" padrões de edificação e urbanismo, com as "melhores" localizações e com os "mais altos" valores financeiros dos imóveis e do solo urbano.

Essa correspondência leva a crer que o valor monetário de um imóvel, seja ele edificado ou não, é calculado mediante procedimentos costumeiros de avaliação, que podem ser realizados por especialistas ou por "leigos", diante da perspectiva hipotética ou efetiva de sua troca no mercado imobiliário ${ }^{102}$. E leva a crer também que nesses processos de avaliação imobiliária, as referências operadas parecem estar baseadas em critérios coletivamente reconhecidos de atribuição de qualidades ao imóvel.

\footnotetext{
${ }^{102}$ Essas considerações irão nos levar novamente a Simmel, aqui interpretado por Arjun Appadurai em $A$ Vida Social das Coisas: "Quanto ao significado da expressão 'valor econômico', o melhor guia (embora não seja o padrão) é Georg Simmel. No primeiro capítulo de A filosofia do dinheiro (1907), Simmel fornece uma descrição sistemática da melhor forma de se definir o valor econômico. Para ele, o valor jamais é uma propriedade inerente aos objetos, mas um julgamento que sujeitos fazem sobre eles" (Appadurai 2008: 15). Appadurai irá seguir o desenvolvimento de sua concepção de valor a partir de Simmel: "É a troca que estabelece os parâmetros de utilidade e escassez, não o contrário, e é a troca que é a fonte do valor: 'A dificuldade de aquisição, o sacrifício oferecido em troca, é o único elemento constitutivo do valor, de que a escassez é tão-somente a manifestação externa, sua objetivação sob a forma de quantidade' (Simmel, 1978, p. 100). Em suma, a troca não é um subproduto da valoração mútua de objetos, mas sua fonte". (Appadurai 2008: 15).
} 
Marshall Sahlins, em Cultura e Razão Prática, realiza uma conexão entre o valor social, o valor econômico e os esquemas simbólicos de classificação nas sociedades capitalistas. Ao tratar do ocidente capitalista desenvolvido, o autor constata que não são critérios exatamente práticos ou funcionais que determinam quais produtos podem ser encontrados em um açougue, e quais são os seus preços: "Bois, porcos, cavalos, cachorros (...) [possuem] diferentes graus de comestibilidade (...). O mesmo se aplica às partes comestíveis do animal". Trata-se, para o autor, de uma lógica que está originalmente relacionada com a proibição do canibalismo, e que atua de modo a classificar e qualificar os animais a serem abatidos e quais as suas partes a serem comidas: “(...) é essa lógica simbólica que organiza a demanda. O valor social (...) é o que estabelece a diferença em seu valor econômico". Do ponto de vista nutritivo, "seria uma posição difícil de defender", a disposição de animais e suas partes em um açougue, já que não há como explicar, por exemplo, o fato de que o filé é mais caro do que a língua, embora exista mais quantidade de filé do que de língua em uma rês abatida (Sahlins 2003: 174-176). Além disso, de acordo com Sahlins, mesmo os critérios funcionais se inscrevem em sistemas simbólicos e valorativos de classificação ${ }^{103}$.

Outro autor que se refere a conexões entre valores sociais e esquemas classificatórios é Bourdieu, que define um valor social, representativo dos objetos apropriados pelos grupos que detêm o poder político e econômico (Bourdieu 2001: 9394). Para Bourdieu, os sistemas simbólicos classificatórios são considerados "estruturas estruturantes", que são "essencialmente o produto da incorporação de estruturas das distribuições fundamentais que organizam a ordem social (estruturas estruturadas)"

\footnotetext{
${ }^{103}$ Como se segue nessas passagens: "Nem mesmo o capitalismo, apesar de sua organização ostensiva por e para a vantagem pragmática, pode escapar dessa constituição cultural de uma práxis aparentemente objetiva. Porque, como Marx também ensinou, toda produção, mesmo quando ela é governada pela forma mercadoria e pelo valor de troca, permanece como produção de valores de uso" (Sahlins 2003: 168-169). Como se segue nessas passagens: "Nem mesmo o capitalismo, apesar de sua organização ostensiva por e para a vantagem pragmática, pode escapar dessa constituição cultural de uma práxis aparentemente objetiva. Porque, como Marx também ensinou, toda produção, mesmo quando ela é governada pela forma mercadoria e pelo valor de troca, permanece como produção de valores de uso" (Sahlins 2003: 168-169). "O valor de uso [entretanto] não pode ser compreendido (...) ao nível 'natural' de necessidades e desejos (...), porque os homens não produzem simplesmente 'habitação' ou 'abrigo': eles produzem unidades de tipos definidos como o castelo de um nobre ou a casa de um camponês (...) processo contínuo de vida social na qual os homens reciprocamente definem os objetos em termos de si mesmos e definem-se em termos de objetos (...). O valor de uso não é menos simbólico ou menos arbitrário que o valor-mercadoria (...) porque a 'utilidade' não é uma qualidade do objeto, mas uma significação das suas qualidades objetivas. O que determina que as calças são de uso masculino e as saias de uso feminino não tem necessariamente conexão com as características físicas ou com as relações que advém dessas características. É por sua correlação em um sistema simbólico e não pela natureza do objeto em si nem por sua capacidade de satisfazer necessidades, que os objetos adquirem valores diferenciados" (idem: 169-170).
} 
(Bourdieu 2001: 119). Sendo “comuns ao conjunto dos agentes inseridos nessa ordem”, as estruturas estruturantes "viabilizam o acordo em meio ao desacordo de agentes situados em posições opostas" (idem.).

De acordo com essa concepção de correspondência entre os objetos, sua classificação e seu valor financeiro, pode-se supor que um dos procedimentos empíricos para uma interpretação propriamente sociológica da estrutura urbana se encontra na busca de alguma compreensão acerca do valor social atribuído aos elementos da estrutura urbana, e da relação entre o valor social e o valor financeiro de um imóvel. Sob esse viés é possível utilizar fontes diversas que possam mostrar categorias discursivas que atribuem qualidades aos elementos da estrutura urbana, tais como podem ser encontradas na imprensa, na publicidade, nos relatórios dos planejadores urbanos ou ainda em conversas cotidianas. Posso citar, para justificar esse procedimento, dois autores brasileiros que chegaram ao conhecimento de esquemas ou conjuntos estruturados de critérios sociais de qualificação de imóveis em diferentes níveis de discurso:

(a) Tereza Pires Caldeira denomina "fala do crime", e considera um tipo de “pensamento classificatório" (Caldeira 2000: 37), o recurso discursivo que está de acordo com a instalação de apetrechos de segurança em um imóvel, contribuindo para a adoção de uma "estética de muros" em São Paulo. A "fala do crime" é detectada pela autora em discursos cotidianos informais (idem: 27). Outras pesquisas empíricas - que se referem à noção de "fala do crime" de Caldeira - indicam que essa espécie de discurso legitima um conjunto de elementos distintivos que equipam os imóveis, inclusive na cidade de Goiânia ${ }^{104}$. Além disso, na pesquisa sobre os condomínios horizontais fechados na cidade de Uberlândia, de Gerusa Gonçalves Moura, foi constatado que a qualificação dos apetrechos de segurança instalados nos condomínios pode fundamentar esquemas de qualificação de condomínios fechados, pois existe uma correspondência entre a qualidade de diferentes apetrechos de segurança (Moura 2008: 107-116). Assim, uma maior qualidade geral e uma maior quantidade "eficiente" de apetrechos e rituais de segurança e de controle, podem ser tomadas para definir a qualidade do próprio condomínio fechado. Qualificado por seus muros, portões e equipamentos de segurança, um condomínio fechado que conta com muros vistosos e dotados de alarmes sofisticados, com viaturas de segurança e com uma portaria

${ }^{104}$ Cf. Moura 2003, Silva 2003, Campos 2007 e Moura 2008. 
imponente, pode ser classificado como um condomínio de alto padrão em relação a outros condomínios com apetrechos de segurança mais modestos e com rituais menos elaborados de passagem para o seu interior.

(b) João Whitaker Ferreira denomina "mito da cidade global" o conjunto de argumentos que, de acordo com uma interpretação padronizada dos modelos teóricos fornecidos por autores como Saskia Sassen (Ferreira 2007: 24), classifica e qualifica uma cidade como um todo, no quadro classificatório, hierárquico e neoliberal das “cidades globais". Se a fala do crime atua marcadamente no discurso informal - mas também na imprensa, como é possível notar facilmente em programas jornalísticos de TV - e a estética que ela afirma é visível em casas isoladas ou em bairros cercados por muros, a valorização da cidade global é geralmente afirmada nos discursos do mundo corporativo e do planejamento público do Estado (idem: 26-28). O discurso da cidade global contribui tanto para o estabelecimento de critérios de qualificação da localização de um imóvel, quanto para a legitimação da produção de uma área concentrada de imóveis considerados bem localizados (ibid.). Essa fonte de recursos para a retórica corporativa gera uma comparação global de cidades com base em critérios hierárquicos, baseados na concentração de capital financeiro, de recursos tecnológicos, de profissionais especializados, etc (ibid.: 23-24). Nesse sentido, a própria funcionalidade dos "edifícios inteligentes" típicos da "cidade global" pode ser uma qualidade capaz de atribuir valor aos imóveis assim classificados ${ }^{105}$.

\footnotetext{
${ }^{105}$ De acordo com Marshall Sahlins: “A singularidade da sociedade burguesa [é] (...) que o simbolismo econômico é estruturalmente determinante" (Sahlins 2003: 149). E ainda: "A estrutura da economia aparece como a consequência objetivada do comportamento prático, em vez de uma organização social das coisas - de acordo com um projeto cultural. (...) O utilitarismo é a maneira pela qual [a sociedade ocidental] se experimenta. Sob qualquer ponto de vista, o processo parece ser de maximização material (...) no lado produtivo, a vantagem material toma a forma de um valor pecuniário acrescido. Para $\mathrm{o}$ consumidor, é mais vagamente entendido o retorno em 'utilidade' da despesa monetária (...) o apelo do produto está em sua pretensa superioridade funcional em relação a todas as suas possíveis alternativas (...) na concepção nativa, a economia é uma arena de ação pragmática" (idem: 167). O autor chega à seguinte conclusão: "é através de aparências que a civilização ocidental transforma a contradição básica de sua construção em um milagre de existência: uma coesa sociedade de estranhos" (ibid.: 202).
} 


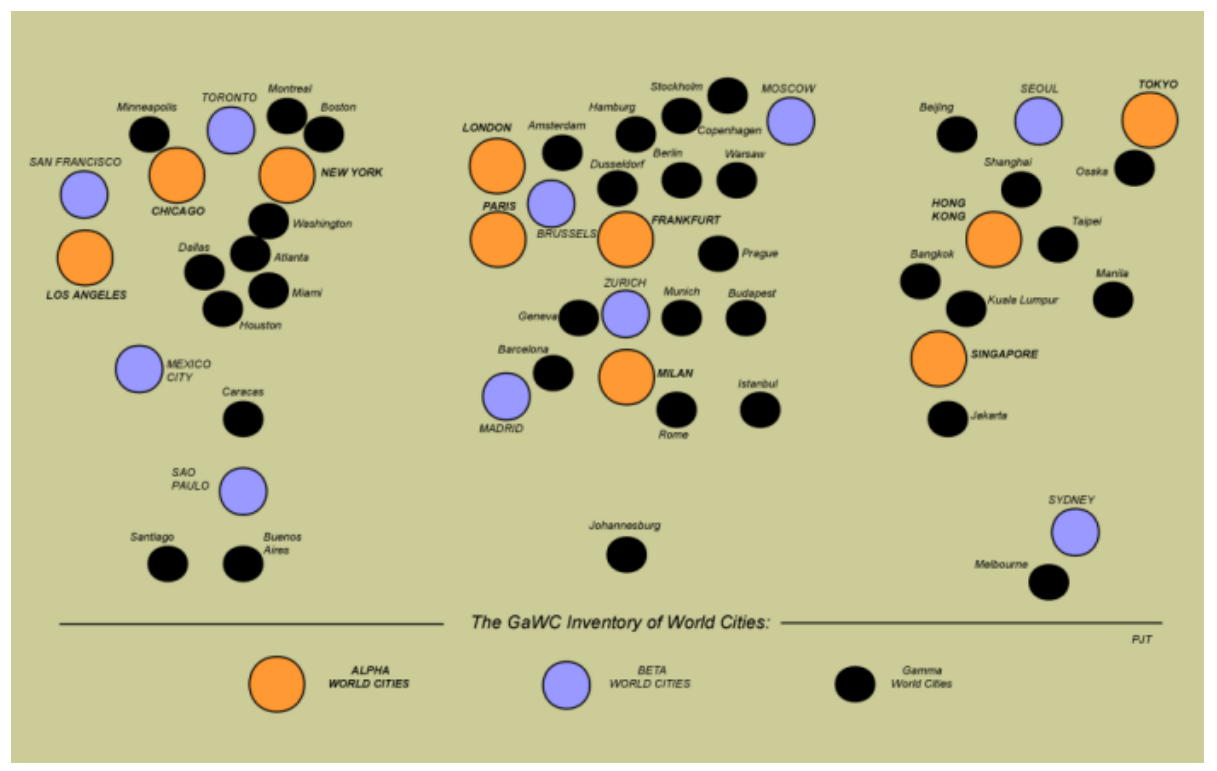

Figura $7 \mathrm{O}$ esquema classificatório das cidades globais. As cidades representadas na cor laranja estão no topo da hierarquia estabelecida e são consideradas cidades globais "alfa". Em azul, as cidades globais "beta", incluindo São Paulo. Em preto, as cidades globais "gama”. Fonte: www.lboro.ac.uk.

Os esquemas de classificação não formam um grande código da cidade, e podem ser formais ou informais, universais ou restritos a grupos específicos. Os critérios de qualidade inscritos nesses esquemas também são diversos e operam em diferentes níveis de comunicação, muitos dos quais são acessados cotidianamente e se inserem no quadro de um "senso comum". Por isso, penso nesses esquemas como indicações e como fontes de contextos específicos de qualificação dos imóveis.

Os esquemas de qualificação dos imóveis são enformados por critérios convencionais de uso do e no espaço, que são convencionalmente aceitos para se descrever um objeto ou uma situação em que ele se insere. Isso quer dizer que existem critérios publicamente aceitos que são considerados quando se assume a verdade de uma sentença como "essa é uma bela casa". Uma afirmação como essa não é verdadeira em sua essência, pois uma "bela casa" em 1930 poderia não atender aos critérios que definem a verdade dessa mesma sentença em 1980, e ainda voltar a atendêlos em 2010. Os critérios de qualificação não determinam em absoluto a qualidade de um imóvel, mas são, antes, elementos convencionais a serem considerados na aferição de sua qualidade ${ }^{106}$. Por exemplo, o conceito de "qualidade de vida" não diz nada do que existe em uma determinada rua da cidade: não diz se existem árvores nas calçadas

${ }^{106}$ Pode-se dizer, seguindo as reflexões de Ludwig Wittgenstein acerca da linguagem cotidiana, que esses critérios convencionais fazem parte dos jogos de linguagem que envolvem a consideração da qualidade de imóveis e regiões da cidade. Segundo Wittgenstein, a verdade das sentenças da linguagem não responde a uma determinação causal, mas responde aos critérios convencionais que fazem parte das práticas cotidianas de interação dos indivíduos humanos. (Wittgenstein 1965: 24-29). 
ou se a rua está perto de um parque urbano, mas ele é usado segundo critérios publicamente aceitos e considerados relevantes para se dizer que uma pessoa tem "qualidade de vida".

Em Goiânia, as áreas que foram convertidas em parques urbanos passaram por dois contextos observáveis de qualificação atribuída. Antes de sua transformação em parques, essas áreas eram consideradas propicias a perigos e aventuras (Medeiros 2007: 220-221), além de serem locais tradicionais de ocupações marginais ${ }^{107}$. Além disso, os critérios qualitativos do urbanismo higienista, que orientaram a instalação de bulevares limítrofes da cidade nas áreas de baixios fluviais, e a nova tradição urbanística das cartas de risco, que alerta a respeito de inundações e erosões, desencorajaram e desencorajam a ocupação dessas áreas ${ }^{108}$. Uma extraordinária transformação ocorreu, no entanto, quando esses baixios e brejos foram urbanizados pelo paisagismo, pela jardinagem e pela instalação de equipamentos de lazer e exercício, e se converteram em parques urbanos. Nesse segundo momento, a mudança na qualidade atribuída ao lugar conduziu à valorização financeira dos imóveis situados em seu entorno, quando esse parque urbanizado se situava em uma área de padrão alto e médio ${ }^{109}$. Mas a produção de parques urbanos ainda não gerou uma valorização imobiliária em seu entorno em áreas de padrão baixo, onde o controle sobre o uso do espaço não se faz de maneira efetiva ${ }^{110}$.

Assim, pode-se afirmar que, em Goiânia, os imóveis de alto padrão se inserem em esquemas classificatórios, hierárquicos e coletivamente reconhecidos, que operam diferentes critérios de atribuição de valor, mas essas atribuições de valor são relativas a grupos e a períodos históricos específicos ${ }^{111}$.

\subsubsection{O sistema de qualificação}

Os critérios de qualidade conectam os diferentes tipos de unidades que podem ser identificadas sobre o espaço urbano. Um bairro considerado nobre é ocupado por edificações consideradas nobres e o valor do metro quadrado é relativamente maior ali.

\footnotetext{
107 Sobre ocupações às margens de córregos em Goiânia, cf. Gonçalves (2002) e Daher (2003). No Brasil, cf. Villaça (2001: 228)

${ }^{108}$ Sobre as influências higienistas no planejamento inicial de Goiânia, cf. Daher 2003.

${ }^{109}$ Como atestam Guimarães (2010) e Ferreira Júnior (2007).

${ }^{110}$ Essa é a conclusão de Cláudia Gomide Guimarães (2010), em um estudo comparativo de dois parques urbanos de Goiânia produzidos no século XXI em margens de córregos: o Parque Flamboyant, na área de expansão dos imóveis de alto padrão, na parte sudeste da cidade, e o Parque Taquaral, em um bairro da periferia, na parte sudoeste da cidade.

${ }^{111}$ Um exemplo importante é dado por Villaça, quando o autor se refere ao surgimento do hábito de freqüentar as praias no Rio de Janeiro, que gerou uma procura de imóveis perto da orla litorânea e a valorização imobiliária das praias cariocas (Villaça 2001: 107-110).
} 
A um bairro residencial nobre corresponde um centro ou sub-centro delimitado como um conjunto de edificações não-residenciais consideradas nobres. A uma casa nobre correspondem materiais de construção e de acabamento nobres e dimensões e estilo apropriados. A uma elite intelectual corresponde um núcleo ou uma faixa boêmia. A uma elite financeira corresponde uma centralidade financeira de alto padrão. A um lugar considerado perigoso corresponde o uso do espaço por indivíduos e grupos não desejados por outros indivíduos e grupos, ainda que seja apenas o uso das ruas para o transporte pedestre. A um bairro nobre correspondem carros nobres. A uma boate cara correspondem carros caros. A uma marina de luxo correspondem barcos de luxo. É em relação à universalidade e à homologia entre os diferentes critérios de qualificação das unidades - agentes e objetos móveis e imóveis - da estrutura urbana que se dá, por exemplo, a eficácia dos critérios de classificação utilizados pelo Censo para gerar diversos esquemas espaciais de classificação social - e diversos esquemas sociais de classificação espacial - que, no entanto são correspondentes e dizem respeito à segregação sócio-espacial.

Bourdieu, ao se referir aos campos sociais, considera que, mesmo que existam diferenças de atribuição de valor, de acordo com os critérios específicos de cada campo, há um sentido hierárquico geral, que é dado por que os agentes que ocupam as posições dominantes em campos específicos estão ao mesmo tempo situados em posições relativamente homólogas em relação ao espaço social como um todo. Esse sentido de significação relativamente universal que atravessa os campos sociais caracteriza o ponto de vista dominante de uma sociedade, como pode ser observado nessa passagem de

\title{
Meditações Pascalianas:
}

\begin{abstract}
A crença política primordial constitui um ponto de vista particular, o dos dominantes, que se apresenta e se impõe como ponto de vista universal, ao cabo de lutas contra visões concorrentes. O que hoje se apresenta como evidente, adquirido, estabelecido de uma vez por todas, fora de discussão, nem sempre foi assim e somente se impôs como tal pouco a pouco: é a evolução histórica que nos faz abolir a história, sobretudo devolvendo ao passado, ou seja, ao inconsciente, os laterais possíveis que se viram descartados, fazendo assim esquecer que "a atitude natural" referida pelos fenomenólogos, ou seja, a experiência primeira do mundo como algo evidente, constitui uma relação socialmente construída, como os esquemas perceptivos que a tornam possível (Bourdieu 2001: 211-212; grifos do autor).
\end{abstract}

Em O Poder Simbólico, Bourdieu afirma que a ordenação hierárquica de estruturas narrativas é parte da "função propriamente ideológica do discurso dominante, intermediário estruturado e estruturante", que tende a "impor a apreensão da ordem estabelecida como natural (ortodoxia)" por meio da "imposição mascarada (logo, 
ignorada como tal) de sistemas de classificação e de estruturas mentais objetivamente ajustadas às estruturas sociais" (Bourdieu 1998: 15). O fato de uma correspondência hierárquica de atribuição de significados "operar de sistema a sistema" permite que "os sistemas de classificação internos reproduzam em forma irreconhecível as taxonomias diretamente políticas" (idem).

No tocante ao espaço físico, os agentes melhor posicionados em diversos campos se arranjam em divisões "de alto padrão" dos usos do solo no espaço urbano. Essas disposições de alto padrão, como mostram os mapas da estrutura urbana, estarão próximas entre si e distantes daqueles agentes pior posicionados em diversos campos. Sob esse ponto de vista, dois aspectos importantes dos critérios de qualificação levam a uma compreensão acerca de como são reconhecidas as similaridades e as assimetrias ocorrentes nos padrões de disposição dos imóveis urbanos.

Em primeiro lugar, os critérios de classificação são coletivamente reconhecidos, e alguns critérios são reconhecidos por grande parte dos habitantes de uma cidade. Esses critérios de maior abrangência possuem uma relativa universalidade. Em segundo lugar, os critérios de qualificação se aplicam a características físicas correspondentes, que são "positivas" em termos da universalidade - do grau de reconhecimento dos critérios -, no caso de um imóvel qualificado como "de alto padrão”. Essas características correspondentes são tais como o número de quartos, a localização do imóvel, a qualidade dos materiais de construção, o número de vagas na garagem, etc. Isso ocorre porque os esquemas classificatórios utilizados são hierárquicos, e porque o sentido dessa hierarquia é definido "de cima para baixo", a partir dos parâmetros daqueles que se situam nas posições mais elevadas do espaço social como um todo. Por isso, posso dizer que existe uma relativa correspondência entre os diversos critérios e esquemas de qualificação dos imóveis e dos conjuntos de imóveis. Um conjunto reconhecido de partes descritas de um imóvel adquire assim o caráter de um estilo arquitetônico-urbanístico ${ }^{112}$.

112 Em A Distinção, Bourdieu considera a apreciação dos estilos: “(...) nesta relação, afirma-se a dependência da disposição estética em relação às condições materiais de existência, passadas e presentes, que são a condição tanto da sua constituição, quanto da sua implementação, além do acúmulo de um capital cultural (sancionado ou não do ponto de vista escolar) que só pode ser adquirido mediante uma espécie de retirada para fora da atividade econômica - que tende a deixar de lado a natureza e a função do objeto representado, além de excluir qualquer reação 'ingênua', ou seja, horror diante do horrível, desejo diante do desejável, reverência piedosa diante do sagrado, assim como todas as respostas puramente éticas para levar em consideração somente o modo de representação, o estilo, percebido e apreciado pela comparação com outros estilos" (Bourdieu 2007: 54). 
Os critérios de qualificação dos imóveis urbanos estão presentes em diversos códigos ou esquemas que não possuem necessariamente uma conexão direta entre si. A princípio, o que dá a eles um caráter integrado de sistema é a universalidade dada por um reconhecimento mais geral, ligado a um paradigma dominante, e a correspondência existente entre diferentes critérios de classificação. Pode-se dizer que o sistema de qualificação de imóveis é um sistema universal de correspondências entre diferentes critérios de qualidade atribuídos aos imóveis, entre diferentes esquemas que operam esses critérios, e entre diferentes imóveis descritos, classificados e qualificados por esses esquemas.

Os critérios de qualificação orientam assim a qualidade geral atribuída a um imóvel, e são operados em um processo de qualificação, que é, ao mesmo tempo, de classificação. Um desses critérios, o valor monetário ou de troca, sempre foi em Goiânia um valor de referência generalizado ${ }^{113}$. Durante a produção e no ato de avaliação imobiliária, os critérios de qualidade atribuídos aos imóveis se concretizam em relação a uma referência universal que é contábil e acumulável, o dinheiro. Mesmo quando o mercado não é o mecanismo utilizado para mediar o procedimento de troca da propriedade de um imóvel - em caso de herança, por exemplo -, o imóvel terá o seu valor calculado com base financeira. O valor financeiro é assim a referência-base da troca imobiliária, e ao mesmo tempo uma referência prática para a avaliação da qualidade imobiliária, que pode representar vários outros critérios de atribuição de qualidade $^{114}$. Na conversão dos outros critérios de qualidade em valor financeiro, a correspondência existente entre os critérios mais reconhecidos será inclusa no valor financeiro de um imóvel, de modo que os critérios positivos de qualificação irão conferir um maior valor financeiro a um imóvel e os critérios negativos irão conferir um menor valor financeiro. Assim, pode-se afirmar que os critérios de qualificação universais e correspondentes são ainda conversíveis em valor financeiro. Essa propriedade será denominada conversibilidade. A conversibilidade, em conjunto com a universalidade e a correspondência, irá contribuir para integrar os critérios e esquemas de qualificação em um sistema de qualificação.

113 Como pode ser notado pelos orçamentos que constam nos relatórios dos primeiros planejadores da cidade.

${ }^{114} \mathrm{O}$ valor financeiro relativamente mais baixo ou mais alto de um imóvel é um critério de qualificação de um imóvel. Se o valor mais alto é uma classificação positiva em termos de status, o valor mais baixo é uma classificação positiva em termos de "relação custo-benefício", e assim um valor considerado mais baixo pode até mesmo aumentar o valor do imóvel, dada a conversibilidade de fatores qualitativos reconhecidos em maior valor financeiro. 
O valor de troca - o valor monetário ou valor de mercado - é uma referência universal para o estabelecimento de um cálculo coletivamente reconhecido do valor de um imóvel, bem como do valor de qualquer objeto e ainda da força de trabalho dos agentes. Mas essa referencia universal não é necessária para a qualificação dos imóveis. Mesmo em uma sociedade que reduz coisas em produtos, estátuas, esculturas, catedrais e palácios convertidos em museus, não necessitam ter um valor financeiro de troca, e pode haver ainda vetos legais que proíbem sua troca no mercado imobiliário ${ }^{115}$.

Dado que a operação de critérios de qualificação dos elementos da estrutura urbana não necessita do cálculo do valor monetário para efetuar a qualificação de fato, o valor de troca de um imóvel é, na qualidade específica de referência-base universal, um valor formal ${ }^{116}$, que nem sempre reflete adequadamente a qualidade atribuída por um indivíduo ou um grupo ao mesmo imóvel. Como no caso em que um processo formal não consegue eficiência plena na avaliação de um imóvel ${ }^{117}$, pois os critérios de qualificação são diversos e algumas vezes ambíguos, além de não serem todos eles apreendidos por um código ou esquema específico de qualificação. Se a universalidade dos critérios de qualificação e suas correspondências são apenas relativas, sua conversibilidade em valor financeiro também será apenas relativa.

Ainda assim, é possível afirmar que diversos tipos de valores sociais atribuídos aos imóveis são coletivamente mediados e quantitativamente objetivados pela referencia de seu valor de mercado, graças à sua conversibilidade em valor monetário.

Em síntese, posso colocar que três características compartilhadas pelos critérios de qualificação irão integrar os esquemas de qualificação dos imóveis urbanos em um sistema de qualificação dos imóveis urbanos: a correspondência entre os diversos critérios, de modo que os diversos critérios de qualificação podem ser reconhecidos como positivos ou negativos; a conversibilidade dos diversos critérios de qualificação das unidades da estrutura urbana em valor financeiro, de modo que critérios positivos ou negativos serão conversíveis, respectivamente, em maior e menor valor financeiro; e a universalidade do reconhecimento dos diversos critérios e esquemas de qualificação da estrutura urbana, orientada em relação a um paradigma dominante.

\footnotetext{
115 Embora sua produção nos dias atuais necessariamente - ao menos por lei - exija o cálculo do financeiro de produção, no caso de uma edificação pública.

${ }^{116}$ Além de ser também um valor de fato, praticado e consumado.

${ }^{117} \mathrm{O}$ valor monetário da troca propriamente dito diverge do valor monetário de troca formal resultante de uma avaliação quando uma troca é feita sob circunstancias que escapam aos padrões da avaliação (venda abaixo ou acima do preço dada por fatores não inseridos nos manuais dos avaliadores, como a pressa para vender ou adquirir um imóvel).
} 
O sistema de qualificação das unidades da estrutura urbana não se aplica apenas aos imóveis, mas pode ser aplicado também aos móveis e agentes que se situam no contexto urbano. Quando aplicado especificamente aos imóveis, os critérios utilizados para atribuir qualidade a um imóvel também podem se referir a objetos e agentes relacionados ao imóvel qualificado. A característica geral do sistema de classificação das unidades da estrutura urbana, sob o ponto de vista desta pesquisa, é a de um sistema relativamente universal de critérios relativamente correspondentes e relativamente conversíveis em valor financeiro. Isso quer dizer que a chave para a verificação e comparação metodológica dos critérios de qualificação das unidades da estrutura urbana em geral e dos imóveis em particular - sem querer dar conta da complexidade inerente a tal sistema - é: (a) a aferição das correspondências entre os diferentes critérios, (b) a aferição do grau da universalidade do reconhecimento dos critérios e dos esquemas, e (c) a aferição do grau de conversibilidade em maior ou menor valor financeiro dos critérios de qualificação.

Os critérios de qualificação das unidades da estrutura urbana são operados formal e informalmente em práticas que podem ser denominadas práticas de qualificação.

\subsubsection{A qualificação}

O sistema de qualificação das unidades urbanas não me parece ser um sistema um sistema de oposições simples, que pode ser "descoberto". Ao contrário, parece ser um sistema extremamente complexo, mas que oferece a possibilidade da descrição de alguns de seus critérios. No caso desta pesquisa, o caminho encontrado para descrever os critérios de qualificação, como mostrado acima, foi o de tomá-los em relação à sua conversibilidade, universalidade e correspondência. Dos esquemas formais de qualificação dos imóveis urbanos, utilizados pelos avaliadores imobiliários, foi tomada a distinção básica entre dois tipos de classificação propiciada pelos critérios de qualificação $^{118}$. Os critérios de qualificação podem atribuir qualidade intrínseca a um imóvel e também atribuir qualidade de localização a um imóvel. Assim, nas práticas de qualificação, pode-se classificar um imóvel por suas próprias características ou pelas

\footnotetext{
118 Nas entrevistas tomadas com um avaliador e com corretores imobiliários ficou evidenciada uma distinção entre o valor intrínseco e o valor de localização de um imóvel. Essa separação entre tipos de critérios de qualidade também pode ser encontradas em pesquisas acadêmicas sobre avaliação imobiliária (cf. Rozembaum e Macedo-Soares 2007).
} 
características de outras unidades da estrutura urbana que, por sua proximidade ou por sua distância, exercem influência sobre a qualidade de um imóvel.

A) A qualidade intrínseca de um imóvel

Inseridos em um sistema de classificação e qualificação, os imóveis de alto padrão se situam no topo de uma hierarquia e, como definidos em um exemplo de esquema formal de classificação de imóveis ${ }^{119}$, são imóveis de luxo ${ }^{120}$. O uso principal desses bens, de acordo com a interpretação que Arjoon Appadurai faz da idéia de moda de Simmel, é principalmente "retórico e social", o que faz desses bens "símbolos materializados" (2008: 56). Tais símbolos são capazes de atribuir distinção aos agentes, como já foi indicado por esta pesquisa ${ }^{121}$.

Se a noção de distinção remete ao papel simbólico dos objetos na classificação dos agentes, a noção de moda se refere a uma contínua sucessão dos objetos que atribuem distinção. A moda é uma forma que a distinção adquire em uma sociedade onde há uma mudança constante dos elementos que atribuem status aos indivíduos e aos grupos sociais. Como coloca Appadurai:

O termo "moda" sugere alta velocidade, rápida rotatividade, a ilusão de um acesso total e de uma alta conversibilidade, a suposição de uma democracia de consumidores e de objetos de consumo. Por outro lado, os meios de troca primitivos, como as leis suntuárias e os tabus, parecem rígidos, de movimento lento, frágeis em sua capacidade de comensurar, ligados a hierarquias, discriminações e posições da vida social. Mas como demonstram tão bem Baudrillard (1981) e Bourdieu (1984), as autoridades estabelecidas que controlam a moda e o bom gosto na sociedade ocidental contemporânea não são menos capazes em limitar a mobilidade social, em demarcar a posição social e a discriminação, e em colocar os consumidores em um jogo com regras constantemente alteradas, determinadas pelos que "ditam o gosto" e seus especialistas afiliados, que habitam o topo da sociedade (Appadurai 2008: 49-50).

Os imóveis estão sujeitos à obsolescência não apenas pelo seu desgaste material, mas também por suas características classificadas pelos critérios de qualificação. Um edifício considerado funcional na década de 70 pode não ser mais

${ }^{119}$ Utilizei aqui o esquema de qualificação de imóveis das pesquisas do CRECI-GO. De acordo com essas pesquisas, os tipos mais caros de padrão imobiliário constituem o "segmento de luxo".

${ }^{120}$ Aos "registros de consumo de luxos", Appadurai designa as seguintes atribuições: "(1) restrição, quer por preço ou por lei, a elites; (2) complexidade de aquisição, que pode ou não ser uma função de 'escassez' real; (3) virtuosidade semiótica, isto é, a capacidade de assinalar, com legitimidade, complexas mensagens sociais (como a pimenta na culinária, a seda no vestuário, as jóias em ornamentos e relíquias em atos de culto); (4) um conhecimento especializado como pré-requisito para serem usados 'apropriadamente', isto é, regulamentação pela moda; e (5) um alto grau de associação entre seu consumo e o corpo, a pessoa e a personalidade". (Appadurai 2008: 57).

${ }^{121}$ Não quero com isso reduzir as características dos bens a marcadores sociais de status: “A competição por status é apenas um dos muitos papéis dos bens de consumo em Belize. Os bens são usados em muitos tipos de apresentação que são transversais ao status (...) eles também são usados na criação e manutenção de todos os tipos de relacionamentos sociais, para a criação de identidades pessoais e para expressar ideais igualitários ao invés de hierárquicos" (Wilk 2004: 46). 
assim considerado atualmente, e uma casa considerada elegante nos anos 70 pode não atender mais a essa consideração. Em suma, os diversos critérios que definem um estilo arquitetônico ou urbanístico podem ou não estar na moda. Dois conjuntos de critérios de atribuição de qualidade intrínseca a um imóvel podem ser relacionados com a noção de moda. Estou me referindo às atribuições de qualidade orientadas pelo "valor do novo" e pelo "valor do clássico".

A constante renovação das concentrações de imóveis de alto padrão através de lançamentos imobiliários, descrita pelo método cartográfico, indica a atribuição de um "valor de novo" atribuído a imóveis recém-construídos. O "valor do novo" pode ser aferido: (a) em termos de correspondências entre critérios de atribuição do "novo" encanamento novo, estilo arquitetônico novo, bairro novo, pintura nova, etc. -, como pode ser observado na prática da avaliação por um especialista ${ }^{122}$; (b) em termos de universalidade, dado o reconhecimento social do valor do novo, como pode ser observado pelo destaque dessa qualidade nos sites de ofertas de imóveis e na publicidade imobiliária, ou ainda em pesquisas de mercado e entrevistas; e (c) em termos de conversibilidade, se o valor do novo for uma qualidade que atribui um maior valor financeiro a um imóvel, como pode ser aferido pela comparação dos preços de imóveis novos e antigos.

É um caso como, por exemplo, o de um automóvel, que se desvaloriza pelo envelhecimento. Um automóvel não envelhece apenas devido ao desgaste técnico, mas também na medida em que se torna obsoleto pelo surgimento de um novo modelo, pelo surgimento de uma nova série do mesmo modelo, ou ainda simplesmente por ter sido adquirido de segunda mão.

Essa forma de valorização pode ser eventualmente substituída pelas reformas e revitalizações de edifícios antigos, que atribuem a edifícios antes envelhecidos um "valor de clássico". O "valor de clássico" pode ser indicado pela noção de retrofit, em voga atualmente entre empreendedores imobiliários do Rio de Janeiro e de São Paulo ${ }^{123}$.

122 Além de constar nos códigos formais dos avaliadores imobiliários, o "valor do novo" fica claro em pesquisas nos sites imobiliários da internet, nos quais alguns apartamentos são anunciados como "novos", ou como construídos há "menos de dez anos", enquanto outros anúncios apresentam indicações sobre o número, disposição e dimensão dos cômodos, ou sobre características morfológicas, como a ausência de garagem, indicando que se trata de um apartamento "velho".

123 A noção de retrofit foi tomada do vocabulário aeronáutico e indica uma atualização ou uma modernização de um objeto considerado desatualizado. Sua aplicação no setor imobiliário indica uma reforma ou restauração orientada para a atualização de equipamentos e instalações de modo a tornar os imóveis compatíveis com a tecnologia atual. Existem muitos exemplos de afirmação dessa tendência que podem ser observados na imprensa. Um deles é o da matéria do jornal carioca O Globo (publicada em 28/04/2012), cujo título é: “Tendência do retrofit chega à Glória". A matéria trata de um conjunto 
Mas ainda não é esse o caso geral da cidade de Goiânia, no tocante à produção e consumo de imóveis de alto padrão. Nessa cidade, o "valor de clássico" é ainda secundário $^{124}$. Por isso, um estudo mais aprofundado sobre o valor atribuído a um edifício considerado clássico e digno de um retrofit, ou sobre o valor atribuído a um edifício tombado como patrimônio, não faz parte do foco principal desta pesquisa.

Ao que parece, a propriedade de atribuir distinção social, conferida por um ou mais imóveis a um ou mais agentes, pode ser observada nos dois referidos conjuntos de critérios de atribuição de valor a edificações urbanas, os que enformam o "valor do novo" e os que enformam o "valor do clássico". O "valor do novo" e o "valor do clássico", como fatores "positivos" em termos de reconhecimento ou de conversibilidade, podem conviver na mesma cidade, e ainda podem se referir a grupos diferentes de agentes, quando um desses conjuntos de critérios é particularmente reconhecido por um grupo social específico.

Um conjunto de critérios que atribui qualidade positiva a um imóvel, e cuja qualidade atribuída pode ser aferida em relação à correspondência, universalidade e conversibilidade, pode ser considerado um estilo arquitetônico-urbanístico da moda. $\mathrm{O}$ próprio "valor do clássico" também pode ser entendido como uma tendência ou como uma moda, se considerado como um modelo em vigor de atribuição de valor aos imóveis urbanos. Em uma cidade onde o dinheiro é o fator-chave para a aquisição e para a avaliação formal do valor social de uma propriedade imobiliária, e onde não existem restrições estatuárias rígidas para vetar a aquisição da propriedade imobiliária a certos grupos de agentes, o poder simbólico de distinção conferido por um imóvel é passível de ser desvalorizado pela reprodução do modelo em que o imóvel se insere. Por isso, antigos esquemas de qualificação podem ser ultrapassados por novos esquemas de

residencial construído em 1942 que foi comprado por uma incorporadora paulistana para ser desocupado e transformado em um conjunto de escritórios.

${ }^{124}$ Richard Wilk encontrou também o "valor do novo" em vigor, no seu estudo realizado em Belize: "A teoria da modernização pode estar em baixo crédito na academia, mas em Belize, como na maior parte do terceiro mundo, ela vive, e bem, como ideologia popular. As polaridades de tradicional e moderno se tornaram modelos populares - em crioulo de Belize "bushy" ou "krofi" em um pólo, e "bright" ou "modan" no outro. Os termos são usados por professores e políticos para descrever aspectos de seus pupilos e de seus constituintes, pela população rural para descrever a si próprios em seu relacionamento com a cidade, por turistas, emigrantes e expatriados para descrever o Belize em outros países. Essas polaridades formam uma parte básica de um discurso do poder enraizado nas noções de tempo e temporalidade. Quando os belizeanos usam esses termos (...), eles estão criando passados e futuros. E objetos de vários tipos desempenham um papel crucial e ativo na construção e uso do tempo e imagens de futuros pessoais e coletivos. (...). Bem como as pessoas usam objetos para inventar tradição, elas também o usam para inventar o futuro" (Wilk 2004: 35). 
qualificação, mesmo que esses novos esquemas atribuam as melhores classificações a imóveis antigos, anteriormente desclassificados.

Quer sejam novos ou clássicos, os imóveis são avaliados, ao que parece, em um processo do tipo "modelo-série" 125 . Os imóveis que se situam no topo da hierarquia de classificação são considerados exemplos e serem seguidos, e são muitas vezes emulados por aqueles imóveis que estão classificados nas posições intermediárias ou médias, e em alguns casos também por aqueles situados nas posições mais baixas, como foi observado na cidade de Goiânia em diferentes oportunidades. Os imóveis de alto padrão são assim as referências-modelo dos estilos arquitetônico-urbanísticos da moda.

Para além do exemplo do clássico e do novo, existem várias outras associações relativamente universais e conversíveis de critérios correspondentes que enformam esquemas de qualificação intrínseca dos imóveis urbanos, esquemas que por sua vez definem os estilos arquitetônico-urbanísticos da moda. Algumas delas já foram referidas, como a "fala do crime" e o "mito da cidade global", ou o "valor do novo" e o "valor do clássico". Essas associações, ou esquemas, possuem assim a capacidade de classificar um imóvel.

Pode-se afirmar com isso que um estilo arquitetônico-urbanístico da moda é aferido em relação à correspondência de uma série de critérios, que é universalmente reconhecida e que apresenta uma taxa positiva de conversibilidade. É em referência a um estilo arquitetônico-urbanístico da moda que se orienta a qualificação intrínseca de um imóvel, que é a qualificação de um imóvel pelas suas próprias características.

B) A qualidade da localização de um imóvel

Se os critérios de qualificação de um imóvel podem dizer respeito às suas próprias características, por outro lado os mesmos critérios de qualificação podem dizer respeito à influência que outros imóveis e outras unidades da estrutura urbana exercem sobre a qualidade de um imóvel. Uma unidade da estrutura urbana que exerce influência perceptível sobre a qualidade de um imóvel específico pode ser considerada uma unidade estruturadora, e um imóvel que exerce influência perceptível sobre a qualidade de outro imóvel será denominado imóvel estruturador.

Um exemplo "negativo" de imóvel estruturador é o de uma favela, cuja proximidade desvaloriza o imóvel avaliado ${ }^{126}$. O mesmo vale para grandes viadutos,

\footnotetext{
${ }^{125}$ Cf. Baudrillard 2008: 153-155.

${ }^{126}$ Como foi afirmado pelo avaliador imobiliário entrevistado.
} 
para avenidas congestionadas e para a vizinhança de áreas industriais. A influência sobre o valor da localização de um imóvel pode ser também negativa devido à influência exercida por agentes e por objetos móveis. Pessoas indesejadas podem atribuir insegurança a uma vizinhança e muitos automóveis podem congestionar uma centralidade ou um sistema viário. Por outro lado, os critérios positivos - em relação à conversibilidade, universalidade e correspondência - que outros imóveis exercem sobre o valor da localização de um imóvel podem ser classificados: (a) quanto à funcionalidade do ponto onde se localiza o imóvel, que pode ser aferida em relação à proximidade de meios e redes de transporte, e de locais de trabalho e lazer; ou (b) quanto à aprazibilidade ${ }^{127}$ conferida pela segurança, pela exclusividade do uso de certos lugares e equipamentos e pela qualidade da paisagem cênica atribuída ao local.

A funcionalidade e a aprazibilidade que a localização atribui aos imóveis são calculadas em relação ao tempo de deslocamento em trajetos hipotéticos realizados entre os elementos estruturadores e os imóveis cuja localização é qualificada em relação aos primeiros. A qualidade da localização de um imóvel urbano é assim medida em termos de acessibilidade ${ }^{128}$. Os trajetos em questão podem ser realizados a pé ou em diversos veículos. Esse processo de delimitação de trajetos hipotéticos leva o corpo humano e os veículos de transporte a serem considerados, nessa perspectiva, como objetos estruturadores. Isso na medida em que a acessibilidade do imóvel qualificado em relação aos imóveis estruturadores é calculada como um conjunto correspondente, universal e conversível de trajetos pressupostos, que poderiam ser efetuados com um ou mais meios de transporte. Como será posto adiante, a qualidade da localização de um imóvel, ou sua acessibilidade, é decisiva para a compreensão da estruturação urbana.

O reconhecimento do valor de localização de diversos pontos, tomado com referência a imóveis estruturadores ${ }^{129}$, pode ser aferido em entrevistas com corretores imobiliários e na publicidade, mas também pode ser codificado em manuais de avaliação imobiliária e nos registros dos mapas de valores do imposto territorial urbano, publicados no Diário Oficial. A esse corpus de informações sobre o valor das localizações irei denominar sistema de localização. Assim como os estilos arquitetônicos e urbanísticos da moda, o sistema de localização de uma cidade pode ser

\footnotetext{
${ }^{127}$ Como nota Villaça (2001: 173-174).

${ }^{128}$ Termo utilizado por Villaça (2001), porém com um sentido similar ao que eu considero como "funcionalidade".

${ }^{129} \mathrm{E}$ em outros casos se referindo outras unidades da estrutura urbana - agentes e objetos móveis. Mas, nos esquemas de qualificação formais e na publicidade, os critérios positivos de qualificação da localização são geralmente aferidos em relação a outros imóveis, os imóveis estruturadores.
} 
incluso no conjunto mais geral já denominado como sistema de qualificação, que reúne critérios que atribuem a qualidade intrínseca e extrínseca de um imóvel em particular e de uma unidade da estrutura urbana em geral.

C) - As escalas de delimitação operadas pelos esquemas de classificação

Existem diferentes níveis de associação ou escalas geográficas em que os agentes operam os critérios coletivos de atribuição de qualidades aos imóveis urbanos. De acordo com Jacques Revel, “cada ator histórico participa (...) de processos (...), se inscreve em contextos de níveis variáveis, do mais local ao global" (1998: 27-28), de modo que é possível conceber significações coletivas operando em diferentes escalas de associação de objetos.

Para Bernard Lepetit, a variação nas escalas de observação colabora para "identificar os sistemas de contextos nos quais se inscrevem os jogos sociais" (1998: 88). Um sistema de contexto possui um "duplo estatuto", pois se trata da "combinação de milhares de situações particulares e ao mesmo tempo dá sentido a todas elas" (idem: 89). Assim, uma perspectiva que leva em conta a variação de escalas é capaz de gerar um modelo de análise que "assegura que não é necessário reproduzir milhares de vezes a experiência" para "se certificar do valor geral do caso" (ibid.). Uma determinada escala "exprime uma intenção deliberada de visar um objeto e indica o campo de referência no qual o objeto é pensado" (ibid.: 93), e "escolher uma escala consiste (...) em selecionar um nível de informação que seja pertinente com o nível de organização a ser estudado" (ibid.: 92).

Essas considerações, aplicadas aos critérios de qualidade na classificação dos elementos urbanos, indicam uma percepção multi-escalonar da cidade por seus habitantes. Os imóveis são qualificados como uma simples edificação ou como associações: um trecho de rua, o entorno de uma praça, um bairro, um setor ou uma região, o centro e a periferia, ou toda uma cidade.

Se a qualificação informa a qualidade intrínseca e a qualidade da localização de um imóvel, as escalas de qualificação "borram" os limites entre esses dois tipos de classificação, já que os critérios que definem a qualidade intrínseca e a qualidade extrínseca de um imóvel podem ser aplicados em diferentes escalas. Não apenas uma casa pode ser considerada nova ou clássica, mas todo um casario. $\mathrm{O}$ estilo arquitetônicourbanístico de um bairro, ou mesmo de uma cidade, pode ser um modelo para uma série estandardizada de bairros e de cidades. No limite, pode-se afirmar que qualquer imóvel 
ou qualquer nível de associação de imóveis pode ser um imóvel estruturador e afetar o valor de outro imóvel, e qualquer imóvel ou qualquer nível de associação de imóveis pode ser qualificado em termos de valor intrínseco. Do mesmo modo, qualquer unidade da estrutura urbana pode ser uma unidade estruturadora e afetar a qualidade de outra unidade, e qualquer unidade da estrutura urbana pode ter um valor intrínseco a ela atribuído.

\subsubsection{A distinção pela qualificação}

Se o papel simbólico dos imóveis e de outras unidades da estrutura urbana como símbolos de distinção se dá pela sua qualificação em esquemas classificatórios, é possível sintetizar agora essa operação:

A distinção dos agentes pelas unidades da estrutura urbana se faz através de práticas de qualificação das unidades pelos agentes, e a qualificação é processada pela operação de critérios de qualificação por parte dos agentes. Os critérios de qualificação podem se inserir em esquemas de qualificação das unidades da estrutura urbana, e estes podem se integrar em um sistema de qualificação das unidades da estrutura urbana. Três propriedades dos critérios de qualificação integram o sistema de qualificação: (a) a correspondência entre os diversos critérios, que constituem assim um estilo arquitetônico-urbanístico, (b) a conversibilidade em maior ou menor valor financeiro, e (c) a universalidade do reconhecimento dos diversos critérios de qualificação da estrutura urbana.

O sistema de qualificação pode classificar um imóvel pelas suas próprias características ou em relação outros imóveis e unidades, os imóveis e as unidades estruturadoras. A qualidade intrínseca de um imóvel é tomada em referência aos estilos arquitetônico-urbanísticos da moda e a qualidade da localização de um imóvel resulta de sua inserção em um sistema de localização. O sistema de qualificação comporta assim os estilos arquitetônico-urbanísticos da moda e um sistema de localização definido em termos de acessibilidade.

Com base nessa argumentação, ofereço a seguinte resposta para a questão acerca de como se dá a distinção dos agentes por parte dos imóveis e de outras unidades da estrutura urbana. A distinção dos agentes pelas unidades da estrutura urbana se dá através da classificação dessas unidades em um sistema coletivamente aceito de qualificação da estrutura urbana. 


\subsection{A terceira questão de pesquisa}

Se a distinção dos agentes pelas unidades da estrutura urbana é possível devido à classificação das unidades, então é preciso se ater aos resultados dessa classificação, no que diz respeito aos seus efeitos sobre a correspondência entre a estrutura física e a estrutura social, cuja explicação é o objetivo desta pesquisa. Assim, a terceira questão desta pesquisa pode ser apresentada nos seguintes termos: Quais são os efeitos do sistema de qualificação da estrutura urbana?

De acordo com Bourdieu, em Meditações Pascalianas, será na busca do reconhecimento que irá se fundamentar "a raiz antropológica da ambiguidade do capital simbólico - glória, honra, crédito, reputação, notoriedade -, princípio de uma busca egoísta das satisfações do 'amor próprio' que é, ao mesmo tempo, a procura fascinada pela aprovação de outrem (...)" (Bourdieu 2001: 202). Aqui aparece um ponto importante, que irá esclarecer sobre como o autor concebe a fonte e a vitalidade das relações de poder e dominação, pois o capital simbólico é um recurso de dominação, que irá favorecer o desenvolvimento de laços de dependência a partir da raiz pedagógica da criação familiar, bem como a crença na validade dos arbítrios que estão por trás desses laços. O habitus, estrutura incorporada, dará eficácia à violência simbólica ${ }^{130}$ que hierarquiza as relações:

Produto da incorporação de uma estrutura social sob a forma de uma disposição quase natural, frequentemente dotada de todas as aparências do que é inato, o habitus é a vis insita, a energia potencial, a força dormente, de onde a violência simbólica, em particular aquela exercida pelos performáticos, extrai sua misteriosa eficácia. O hábito também constitui o princípio dessa forma particular de eficácia simbólica, a "influência" (de uma pessoa - "as más influências" -, de um pensamento, de um autor etc.) (idem: 205).

Será por isso que Bourdieu afirmará que: "a eficácia das necessidades externas se apóia na eficácia de uma necessidade interna" (ibid.: 206). Para Bourdieu, a dominação vai além dos limites da "consciência racional", pois ela está inscrita na illusio que estrutura o habitus, e, consequentemente, no próprio habitus:

Logo, sendo o resultado da inscrição no corpo de uma relação de dominação, as disposições constituem o verdadeiro princípio dos atos práticos de conhecimento e reconhecimento da fronteira mágica entre dominantes e dominados, atos desencadeados pela magia do poder simbólico, atuantes, nesse caso, como um gatilho. Os dominados contribuem, com frequência à

130 “A violência simbólica é essa coerção que se institui por intermédio da adesão que o dominado não pode deixar de conceder ao dominante (portanto, à dominação), quando dispõe apenas, para pensá-lo e para pensar a si mesmo, ou melhor, para pensar sua relação com ele, de instrumentos de conhecimento partilhados entre si e que fazem surgir essa relação como natural, pelo fato de serem, na verdade, a forma incorporada da estrutura da relação de dominação (...)” (Bourdieu 2001: 206). 
sua revelia, outras vezes contra sua vontade, para sua própria dominação, aceitando tacitamente, como que por antecipação, os limites impostos; tal reconhecimento prático assume, muitas vezes, a forma da emoção corporal (vergonha, timidez, ansiedade, culpabilidade), em geral associada à impressão de uma regressão a relações arcaicas, aquelas características da infância e do universo familiar. (...) (ibid.: 207-208).

Esse caráter incorporado das relações de dominação se mostra na constatação de que "as relações simbólicas de força são relações de força que se instauram e se perpetuam por intermédio do conhecimento e do reconhecimento, o que não significa dizer por meio de atos intencionais de consciência" (ibid.: 242). Sua transmissão ocorre no próprio âmbito pré-reflexivo da comunicação imediata, que irá transmitir as disposições para a dominação e para o poder simbólico:

Eis aí o âmago da transmutação que constitui o fundamento do poder simbólico, como poder que se cria, se acumula e se perpetua em virtude da comunicação, da troca simbólica: (...), a comunicação converte relações de força bruta, sempre incertas e suscetíveis de serem suspensas, em relações duráveis de poder simbólico pelas quais se é obrigado e com as quais a gente se sente obrigado; ela transfigura o capital econômico em capital simbólico, a dominação econômica em dependência pessoal (por exemplo, com o paternalismo), até em devotamento, em piedade (filial) ou em amor. (...) (ibid.: 242-243).

A dominação não irá ganhar em eficiência se permanecer sempre calcada em sua "força nua e crua, a das armas ou a do dinheiro" (ibid.: 209), sua eficiência está baseada principalmente em sua estruturação na dimensão simbólica, aquela veiculada pela comunicação. No âmbito da dimensão simbólica do conhecimento e do reconhecimento, “os atos de submissão, de obediência, (...) mobilizam estruturas cognitivas suscetíveis de serem aplicadas a todas as coisas do mundo e, em particular, às estruturas sociais”. (ibid.). São essas estruturas cognitivas que Bourdieu denomina "estruturas estruturantes" (ibid.) e as trata como formas historicamente construídas, "arbitrárias, no sentido de Saussure e Mauss, cuja gênese social pode ser retraçada" (ibid.: 210). Bourdieu está próximo aqui de Durkheim, que associou as formas de classificação com as estruturas dos grupos nas sociedades fundamentadas na solidariedade mecânica (ibid.).

Será nesse ponto que podemos destacar a importância dos agentes como reprodutores das relações de poder, pois:

(...) para que a dominação simbólica seja instituída, é preciso que os dominados tenham em comum com os dominantes os esquemas de percepção e de apreciação segundo os quais uns e outros são percebidos reciprocamente; é preciso que eles se percebam tal como se lhes percebe; quer dizer, que seu conhecimento e seu reconhecimento encontrem seu princípio nas disposições práticas de adesão e de submissão, as quais, sem passar pela deliberação e pela decisão, escapam à alternativa entre o consentimento e a coerção (ibid.: 243). 
É possível conceber aqui um paradigma dominante ${ }^{131}$, que irá orientar o sistema de qualificação das unidades da estrutura urbana, e que legitima as práticas de agentes dominantes, os quais podem ser reconhecidos justamente por sua identificação com o paradigma dominante ou por seu papel na constituição e na reprodução deste paradigma. Nesse sentido, pode-se afirmar que o sistema de qualificação dos imóveis urbanos se insere em um paradigma cultural dominante mais geral.

No caso de Goiânia, cidade planejada nos anos 30, seu primeiro plano diretor antecipou a implantação da cidade, e pode ser associado ao paradigma dominante do período $^{132}$. No primeiro plano diretor de Goiânia podemos encontrar uma diferenciação hierárquica dos setores de moradias, pois o plano distribui as residências de acordo com três grupos de agentes ou classes sociais associadas ao espaço urbano: os "operários", os "funcionários", e a "elite" (Cf. Cordeiro 1989), esta última destinada a residir nas melhores moradias. As melhores moradias foram planejadas dispostas nas proximidades do centro cívico, destinado a abrigar a sede do governo estadual ${ }^{133}$.

Aos agentes bem posicionados em relação ao paradigma dominante ou ao sistema de classificação dos imóveis urbanos, denomino agentes estruturadores. Os três grupos de agentes estruturadores dominantes identificados por esta pesquisa são o Estado, os produtores imobiliários especializados em imóveis de alto padrão e a classe dominante do espaço urbano.

Assim, a questão acerca dos efeitos do sistema de qualificação pode ter uma resposta nos seguintes termos: O efeito geral do sistema de qualificação da estrutura urbana é a atribuição universal de legitimidade à dominação do espaço urbano, o que identifica o sistema de qualificação a um paradigma cultural dominante, que corresponde a um ponto de vista dominante. O que está inscrito no sistema de qualificação da estrutura urbana é a lógica da dominação do espaço urbano, que é exercida pelos agentes estruturadores dominantes.

\footnotetext{
${ }^{131}$ : O que seria o equivalente ao que Bourdieu denomina como a cultura dominante nessa passagem de "O Poder Simbólico": “As ideologias, por oposição ao mito, produto coletivo e coletivamente apropriado, servem interesses particulares que tendem a apresentar como interesses universais, comuns ao conjunto do grupo (...). Este efeito ideológico, produz-lo a cultura dominante dissimulando a função de divisão na função de comunicação: a cultura que une (intermediário da comunicação) é também a cultura que separa (instrumento de distinção) e que legitima as distinções compelindo todas as culturas (designadas como subculturas) a definirem-se pela sua distância em relação à cultura dominante.” (Bourdieu 1998: 11).

${ }^{132} \mathrm{Na}$ medida em que plano de Goiânia representava modelos de desenvolvimento, de modernização, de habitação e de urbanismo, além de se associar a mudanças na configuração do poder político de Goiás. Para uma análise do planejamento de Goiânia inserido ao pensamento político dominante, cf. Wilton 2010.

${ }^{133}$ Tal distinção parece não existir no plano piloto de Brasília, o que não contribuiu, no entanto, para a criação e desenvolvimento de uma cidade não segregada.
} 


\subsection{A quarta questão de pesquisa}

Se o sistema de qualificação das unidades da estrutura urbana é operado pelos agentes, então a próxima questão a ser apresentada pode ser referir ao papel da agência na qualificação. Além disso, se o sistema de qualificação das unidades da estrutura urbana se refere a uma lógica da dominação, é preciso esclarecer essa lógica. Assim, a quarta questão de pesquisa pode ser apresentada nos seguintes termos: Como os agentes exercem a dominação do espaço urbano?

Uma lógica da dominação legitimada pelo sistema de qualificação das unidades da estrutura urbana me parece estar ligada ao controle da disposição espacial dos imóveis e, no limite, de todas as unidades da estrutura urbana. Os agentes estruturadores dominantes são aqueles que controlam a distribuição dos imóveis e das unidades que são mais positivas em relação ao sistema de qualificação. Essa capacidade de controle sobre a disposição dos elementos da estrutura urbana pode ser chamada de poder de dominação do espaço urbano.

\subsubsection{A dominação do espaço urbano}

As considerações expostas logo acima vão ao encontro do meu entendimento da visão de Bourdieu sobre a segregação sócio-espacial urbana, como apresentada em "Efeitos do lugar". De acordo com Bourdieu, o espaço apropriado hierarquicamente também classifica hierarquicamente aqueles que dele se apropriam, e seus benefícios são os resultados das lutas travadas em diferentes campos do espaço social (Bourdieu 1999: 163). Os benefícios atribuídos pela apropriação de determinado espaço "tendem a tomar a forma de ganhos de localização" (idem). Esses ganhos de localização podem ser considerados como resultantes da dominação do espaço urbano, e dependem do capital, em suas diversas formas.

O capital permite manter à distância as pessoas e as coisas indesejáveis ao mesmo tempo em que aproximar-se de pessoas e coisas desejáveis (por causa, entre outras coisas, de sua riqueza em capital), minimizando assim o gasto necessário (principalmente em tempo) para apropriar-se deles: a proximidade no espaço físico permite que a proximidade no espaço social produza todos seus efeitos, facilitando ou favorecendo a acumulação de capital social e, mais precisamente, permitindo aproveitar continuamente encontros ao mesmo tempo casuais e previsíveis (...) (ibid.: 164).

Essa passagem exemplifica a agência que reforça e é reforçada pela relativa correspondência entre a posição que os agentes ocupam no espaço social e o lugar que eles ocupam no espaço urbano. Leva-se em conta nessa construção uma distribuição de 
imóveis representativa de uma distribuição de posições sociais, que garante aos agentes que se apropriam dos espaços mais valorizados os assim chamados "ganhos de localização", e o capital é o recurso utilizado para a obtenção desses ganhos.

$\mathrm{Na}$ verdade, um agente, grupo ou instituição se encontra sempre em uma situação passível de exercer uma dominação ao menos temporária sobre o espaço urbano. O Estado com seu planejamento, suas desapropriações, suas leis e sua polícia; os proprietários com suas escrituras; os empreendedores com seus projetos, suas obras e seus operários contratados; o extrato de alta renda, que compra apartamentos de luxo através de financiamentos programados ${ }^{134}$; a elite, como um grupo de status que vai à ópera ou ao jóquei clube ${ }^{135}$; a classe média, que emula e estandardiza estéticas arquitetônicas antes restritas à classe alta $^{136}$; a classe média baixa, que consome os produtos da verticalização em áreas cada vez mais distantes do centro expandido; os boêmios, que mudam para o centro velho preparando o terreno para a especulação imobiliária; os traficantes que degradam uma praça; os mendigos que ocupam nichos embaixo de viadutos; a viatura policial que passa devagar por uma rua; a multidão enfurecida que se dedica ao linchamento de um ladrão; os assaltantes que abordam um pedestre em uma rua escura; os moradores de um condomínio fechado que se deslocam de automóvel em direção ao shopping-center ou ao hipermercado; a hostess da casa noturna que seleciona pela aparência ou pelo vestuário quem poderá adquirir o ingresso de entrada; o operador de um sistema de câmeras de vigilância, etc.

A dominação de um espaço, como no exemplo do centro de Nova Iorque estudado por Zukin (2004), pode apagar os símbolos associados a outros paradigmas que não aquele dominante. Em Goiânia, muitos bairros de baixo padrão - ocupados, portanto, pela classe dominada do espaço urbano - tiveram seus nomes apagados: Vila Operária, Bairro Botafogo, Bairro Operário (Setor Norte), Macambira ${ }^{137}$. Por outro lado, o Setor Marista, ocupado por sobrados e mansões a partir dos anos 70 e principalmente nos anos 80 e 90, surgiu por meio de uma sucessão de decretos que

\footnotetext{
${ }^{134}$ Ou seja, um grupo social delimitado pela afinidade da renda familiar.

${ }^{135}$ Ou seja, um grupo social que pode ser delimitado por afinidades de gosto, por afinidades de educação ou por afinidades de costumes, incluindo hábitos de consumo.

${ }^{136}$ Aqui definida por afinidades na classificação de suas residências, que ocupam um papel intermediário na relação modelo-série, relação esta orientada a um estilo arquitetônico da moda.

${ }^{137}$ Cf. Oliveira 1998, Gonçalves 2002, Daher 2003.
} 
transformaram partes de três antigos bairros em um novo bairro, legitimando um processo dominante de produção, ocupação e uso do espaço urbano ${ }^{138}$.

Os diferentes recursos de dominação utilizados pelos agentes oferecem um sentido ampliado de propriedade de uso do espaço. Tais recursos de disposição de elementos sobre o espaço serão considerados por esta pesquisa recursos de dominação do espaço urbano. Mas, no que se refere ao sistema de qualificação das unidades da estrutura urbana, a universalidade dos seus critérios garante a eficiência dos meios de dominação do espaço utilizados especificamente pelos agentes dominantes. Nessa perspectiva, devo colocar mais uma vez que o padrão de referência para todos os outros tipos de recursos de aquisição fundiária, inclusive para o poder político e jurídico do Estado, é o capital financeiro. O capital financeiro é uma garantia básica da propriedade do espaço urbano, tanto no que se refere à propriedade de produção quanto à propriedade de uso ou de consumo dos imóveis produzidos. O que garante a importância do capital financeiro como meio de dominação do espaço urbano é a conversibilidade em valor financeiro dos diversos critérios de qualificação inseridos em um sistema de classificação orientado ao paradigma dominante. Se os imóveis melhor qualificados são aqueles mais caros, então sua propriedade será restrita àqueles detentores, antes de tudo, de mais capital financeiro.

No entanto, o poder do Estado no controle do dispositivo urbano também é fundamental. Para Bourdieu, em Meditações Pascalianas, o Estado é um agente determinante para a "produção e a reprodução dos instrumentos de construção da realidade social" e, portanto, do senso comum nacional. Tal se faz pela imposição, "na realidade e nos cérebros", de princípios fundamentais de classificação (Bourdieu 2002: 212).

O papel regulador do Estado sobre a disposição dos elementos urbanos fica claro através da análise dos planos diretores de uma cidade. Os planos diretores normatizam ações que geram uma força estruturadora legítima, pois fundamentada na lei, e legitimadora, pois imbuída de autoridade legal para estabelecer locais específicos para a distribuiçãa dos usos do solo. As ações orientadas por esse modelos de ação que são os planos diretores efetivam assim vários tipos de classificações e ordenações espaciais

\footnotetext{
${ }^{138}$ Como mostram as matérias jornalísticas conferidas na pasta do Setor Marista, na sessão de bairros do arquivo da SEPLAM.
} 
urbanas, inscritas nos mesmos planos ${ }^{139}$. O poder regulatório, além disso, não é o único recurso de dominação do espaço urbano utilizado pelo Estado. Como ocorreu no início da história de Goiânia, quando o Estado monopolizou os loteamentos melhor localizados e a produção dos imóveis de alto padrão, ele também quantificou sua produção em termos de valor monetário, como fazem os produtores e especuladores privados. Além de produtor, nesse período o Estado foi também especulador imobiliário e produtor de vazios urbanos, por ter utilizado a propriedade imobiliária para garantir a viabilidade de seus projetos urbanísticos de longa escala, ao reservar terras próximas ao centro da cidade para futuros lançamentos imobiliários ${ }^{140}$. Em Brasília, como outro exemplo, é a propriedade imobiliária estatal dos vazios urbanos do entorno ao PlanoPiloto que até hoje garante o isolamento físico e social dessa parte da cidade, evitando a sua conurbação com as cidades-satélite ao impedir a entrada dos terrenos vazios no mercado imobiliário $^{141}$.

O grau máximo do poder de dominação da disposição de elementos sobre o espaço, em tese, é a força física exercida de maneira coercitiva por certos agentes. Mas, em Goiânia, o grau generalizado de eufemização dessa força é o poder econômico, o principal meio de dominação do espaço urbano, tanto em termos de produção quanto em termos de consumo. O poder econômico, porém, é regulado pelo poder do Estado de planejamento e jurisdição sobre o espaço urbano, e até mesmo de desapropriação da propriedade imobiliária. A associação entre o poder econômico e o poder regulatório do Estado é orientada pelo sistema de qualificação e ao mesmo tempo é orientadora do sistema de qualificação.

Com isso, pode-se afirmar que a dominação do espaço urbano é garantida pelo poder regulatório do Estado e pela conversibilidade dos critérios de qualificação em valor monetário, o que permite aos detentores do capital financeiro a aquisição, a manutenção, a produção e os direitos de uso das propriedades imobiliárias melhor

139 Os planos diretores podem refletir tanto o sistema de disposições dos setores dominantes, daqueles detentores do capital econômico (como no caso da influência do modelo da "cidade global" que pode priorizar áreas como a região da Berrini em São Paulo), como também as lutas pelo direito à moradia e à infra-estrutura, e ainda a posição de pesquisadores e outros profissionais envolvidos no planejamento urbano.

${ }^{140}$ Estou me referindo às áreas que vieram a constituir o Setor Sul, o Setor Oeste e o Setor Marista.

${ }^{141}$ De acordo com Pedro Calil Jabur: "Em razão desta situação, a expansão urbana no DF está submetida tanto às regras das políticas do Estado, quanto às leis de mercado de valorização e uso das terras e condicionada por um processo no qual este mercado somente obtém acesso legal à terra mediado pelas regras do poder governamental. Esta propriedade de terra transforma o Estado no detentor do maior capital imobiliário de Brasília, formado pelo estoque de terras dos assentamentos existentes em constante valorização, e por aqueles outros espaços em processo de licitações e que possuem seus preços valorizados de acordo com o uso e o padrão urbanísticos que será destinado ao terreno" (Jabur 2003: 26). 
qualificadas no sistema de qualificação e, portanto, capazes de atribuir a distinção aos seus proprietários e usuários.

\subsubsection{Os agentes estruturadores dominantes}

Os agentes estruturadores dominantes são aqueles que utilizam os recursos privilegiados de dominação da disposição dos elementos sobre a estrutura urbana, o que quer dizer que sua identificação empírica como agentes dominantes se faz com base na avaliação de seus recursos de dominação da disposição de unidades na estrutura urbana. Assim definidos, os agentes estruturadores dominantes podem ser considerados aqueles que regulam, produzem e consomem os imóveis de alto padrão a eles associados.

Os recursos de dominação dos agentes dominantes são diversos, destacando-se os que configuram o poder do Estado de legislação e controle e o poder econômico e a propriedade de uso sobre as unidades da estrutura urbana, esta capaz de atribuir a distinção aos agentes. Assim, pode-se afirmar que o poder regulatório, o poder econômico e a própria propriedade imobiliária e mobiliária, são os principais recursos de dominação do espaço urbano.

O poder do Estado regulamenta o mercado de distribuição dos imóveis. O capital econômico é o meio básico de domínio dessa distribuição, na qualidade de recurso de aquisição de propriedade imobiliária, seja ela destinada à produção ou ao consumo. A propriedade imobiliária, adquirida ou não pelo capital financeiro, pode garantir o domínio dos imóveis intrinsecamente melhor qualificados e assim capazes de atribuir distinção. Além disso, a propriedade do uso dos móveis estruturadores automóveis, metrô, bicicletas e o próprio corpo no caso dos trajetos serem efetuados a pé - adequados para o deslocamento entre imóveis sobre um sistema de transporte, garante aos agentes dominantes o controle da acessibilidade, que por sua vez orienta a qualidade da localização de um imóvel. Assim, aos principais recursos utilizados pelos agentes dominantes do espaço urbano, que foram identificados por esta pesquisa, irei denominar: o capital financeiro, a propriedade e o poder regulatório.

Atribuídos e atribuidores de valor social e organizados em diferentes níveis de associação, os agentes estruturadores dos imóveis urbanos de alto padrão atuam como produtores e consumidores desses imóveis. Com isso, os agentes estruturadores se beneficiam do papel dos imóveis de alto padrão como símbolos de distinção dispostos sobre o espaço urbano. Os imóveis urbanos de alto padrão são assim conectados cotidianamente aos agentes dominantes, na medida em que são coletivamente 
identificados e utilizados pelos agentes dominantes e por outros agentes, em reconhecimento ao paradigma dominante. Como no exemplo retirado da obra de Fraya Frehse.

Em um estudo que observou mudanças em representações sociais e nos padrões de conduta da elite paulistana do século XIX, a autora registrou transformações associadas, no significado da categoria "rua", e no uso dos imóveis urbanos nomeados por essa categoria. No recorte temporal mais antigo analisado pela autora, anterior à implantação da primeira estrada de ferro - em 1865 - na cidade de São Paulo, a rua “aparece apenas como cenário espacial de permanências, passagens e ajuntamentos excepcionais ou periódicos" (Frehse 2006: 222). Já no segundo recorte temporal, posterior ao advento da ferrovia, a rua "se destina principalmente a atividades que implicam a circulação de tipos humanos por ali: a frequência a cafés, restaurantes, confeitarias, jardins públicos, bondes" (idem). Por passar a ser local frequentado regularmente pela elite, e particularmente pelas mulheres da elite, "a rua torna-se uma referência espacial real ou imaginária na rotina de ao menos alguns desses indivíduos" (ibid.).

Assim, tornando-se parte da rotina de um grupo social capaz de atribuir um valor positivo em relação ao paradigma dominante em vigor no período histórico considerado, certas ruas de São Paulo passaram ser uma referência para novas e valorizadas atividades sociais. É possível considerar que, se as ruas passaram desse modo a "atrair" agentes da elite para uma nova forma de sociabilidade cotidiana, por isso foram instalados ali os cafés, os restaurantes, os jardins e os bondes citados pela autora. Apresenta-se aqui uma indicação do processo pelo qual os imóveis são ordenados como resultado efetivo de padrões de atuação social; ou seja, apresenta-se uma indicação de como a estrutura da cidade é moldada pelos agentes que a usam e a dominam. Isso quer dizer que toda a estruturação urbana em primeiro grau é efetuada por agentes estruturadores. Os outros elementos estruturadores considerados por esta pesquisa o são apenas em segundo grau, por afetarem as ações dos agentes.

Em Goiânia, os agentes estruturadores do espaço urbano de alto padrão - ou os agentes dominantes do espaço urbano - identificados por esta pesquisa são: (a) o Estado, (b) os agentes ou produtores imobiliários que produzem o espaço urbano melhor qualificado, e (c) a classe dominante do espaço urbano, que é destacada devido 
o seu papel de orientadora para a ação dos outros agentes dominantes, que produzem e regulam o espaço apropriado pela classe dominante ${ }^{142}$.

Em termos "bourdieanos", as classes de agentes podem ser delimitadas em relação a um espaço social, compreendido como um campo abrangente que engloba diversos campos ${ }^{143}$. É um espaço social como um todo que está reificado pelo espaço físico da cidade como um todo, espaço físico que engloba diversas unidades significadas e inseridas na estrutura urbana. Por sua correspondência com os agentes dominantes, os imóveis de alto padrão podem representar um campo do poder, que é o campo dominante de um espaço social ${ }^{144}$. Por outro lado, os campos específicos do espaço social podem ser associados a frações de classe específicas, cujos recursos são apropriados às especificidades de cada campo, mais do que ao conjunto do espaço social, que por sua vez é dominado pelos agentes bem posicionados em relação ao campo do poder, e que se valem dos recursos políticos e econômicos.

O drama urbano da "fração dominada da classe dominante" - quer seja formada pelos boêmios e artistas, pressionados para deixar a Vila Madalena pelo extraordinário valor de troca atribuído aos imóveis do bairro, ou pelos aristocratas de Campos do Jordão, acossados pela "descoberta" do local por uma poderosa classe média alta consumidora de casas geminadas e de jantares em restaurantes kitsch - está na conversibilidade de seus valores estéticos, históricos, de gosto ou de uso em valor financeiro. Mesmo que os recursos políticos ou legais mobilizados por esses grupos para defender seu estilo de vida ameaçado consigam prolongar a sua capacidade de resistência, estes são recursos acessórios diante do mercado imobiliário. Isso significa que qualquer grupo que tem o poder de ocupar um espaço é o grupo dominante de um espaço, enquanto durar a eficácia desse poder. Porém, os agentes que constituem a classe dominante do espaço urbano usufruem os ganhos de sua associação a um sistema dominante de qualificação, que é relativamente universal em termos de reconhecimento e relativamente conversível em valor financeiro.

Em suma, os agentes estruturadores dominantes são aqueles que se valem dos recursos mais importantes para efetuar a dominação do espaço urbano. Como agentes estruturadores dominantes identificados, temos o Estado, os produtores dos imóveis de

\footnotetext{
142 Villaça (2001) ressalta a importância de uma classe dominante do espaço urbano e seu papel de controle da acessibilidade entre diferentes imóveis, o que exerceu influência sobre as considerações teóricas desta pesquisa.

${ }^{143}$ Cf. 4.1 acima nesta dissertação.

${ }^{144}$ Vide figura 57.
} 
alto padrão e a classe dominante do espaço urbano. Os recursos disponibilizados pelos agentes estruturadores que foram identificados são o capital financeiro, a propriedade imobiliária e o poder político-regulatório.

\subsubsection{A classe dominante do espaço urbano}

Com o referencial acima apresentado é possível estabelecer uma relação entre os grupos de agentes estruturadores dominantes e seus recursos de dominação: (a) $\mathrm{O}$ Estado detém o monopólio formal do poder de regulação e controle sobre a produção e o uso do espaço urbano, (b) os produtores imobiliários se valem da propriedade fundiária e do capital financeiro para a produção dos imóveis, e (c) a classe dominante do espaço urbano se vale da propriedade imobiliária, do capital financeiro e dos padrões de gosto para dominar os estilos arquitetônico-urbanísticos da moda, assim como se vale da propriedade imobiliária, do capital financeiro e dos móveis estruturadores para dominar o sistema de localização. Dado o domínio do sistema de qualificação - o domínio dos estilos arquitetônico-urbanístico da moda pela apropriação dos imóveis melhor qualificados e o domínio das melhores localizações aferidas em termos de acessibilidade - por parte da classe dominante do espaço urbano, é possível também conectar a agência aos esquemas classificatórios e ao seu caráter hierárquico coletivamente conhecido. Os exemplos seguintes permitem conceber os imóveis urbanos como símbolos de distinção utilizados por grupos sociais dominantes.

O primeiro exemplo é dado por Luciana Teixeira de Andrade (2006), que descreveu os estilos de vida de dois diferentes grupos sociais habitando um dos primeiros condomínios fechados de Belo Horizonte. Um dos grupos é representado por moradores mais antigos, para os quais o bairro representa "um símbolo de vida alternativa" (Andrade 2006: 325). O outro grupo é aquele taxado pelos primeiros como os "novos-ricos", que está em harmonia com as tendências dominantes no momento da pesquisa da autora, e que valoriza os apetrechos de segurança e os muros ${ }^{145}$. De acordo com a autora, para "desconforto e tensão" dos mais antigos moradores, estava ocorrendo uma "mudança de significado do lugar onde residem, que de espaço alternativo passou a espaço dos "novos-ricos"” (idem).

\footnotetext{
145 Para a autora, enquanto os "pioneiros" marcam seu estilo de vida como a busca de um lugar próximo da natureza, também marcam suas diferenças com os novos moradores ao atribuir-lhes a busca de status e segurança (Andrade 2006: 317). De acordo com a autora, os novos moradores "levam para o condomínio suas recentes experiências de medo nos bairros onde residiam, histórias de assalto a casas, sequiestrosrelâmpago, etc". Já os moradores antigos "não partilham desse sentimento" (idem: 319). Mas nesse condomínio, o estilo de vida dos outsiders se impõe sobre o dos estabelecidos, já que "se a segurança se transformou em bem posicional, provavelmente tenderá a se manter e até mesmo a se intensificar” (ibid.).
} 
A leitura do texto de Andrade leva a pensar em dois diferentes contextos sociais e históricos de atribuição de qualidade a esse condomínio fechado, que correspondem a dois estilos de vida e a dois arquitetônico-urbanísticos. Os critérios de qualificação reconhecidos pelos "novos-ricos" passam a adquirir um caráter dominante, ao serem imbuídos de uma universalidade propiciada pela aceitação geral de um paradigma dominante. Isso quer dizer que os critérios de qualificação dos "novos-ricos" entraram na moda, enquanto os critérios de classificação dos "pioneiros" saíram de moda.

Em sintonia com as categorias discursivas associadas aos "novos-ricos", está o já referido estudo etnográfico de Moura (2003), realizado em Goiânia na virada do século. A etnografia destaca a ênfase na segurança, recorrente em debates micropolíticos e orientada pela atuação de um corpo de especialistas e técnicos de segurança. A ênfase na segurança era, na época do estudo, um recurso retórico eficaz em termos de orientação de votos, conforme utilizado nas assembléias de moradores de um condomínio horizontal fechado.

Também em Goiânia, minha pesquisa registrou que todos os condomínios horizontais fechados de alto padrão construídos no século $\mathrm{XXI}^{146}$ estão de acordo com padrões estéticos compatíveis com os que definem o estilo arquitetônico-urbanístico dos "novos-ricos", e estão ainda de acordo com o padrão mais alto da tipologia de padrões de condomínios fechados elaborada por Moura (2008). Mas os novos condomínios horizontais fechados não estão de acordo com o estilo arquitetônico-urbanístico dos "pioneiros" das décadas anteriores, que não estão mais em voga e que podem se associados aos condomínios fechados mais antigos de alto padrão da tipologia de Moura $^{147}$. Eis aqui um exemplo de como a sucessão de estilos arquitetônicourbanísticos da moda pode se relacionar com a sucessão de grupos sociais que dominam uma vizinhança.

\footnotetext{
${ }^{146}$ De acordo com a classificação e os dados referentes à produção de condomínios fechados das pesquisas do CRECI-GO. Isso quer dizer que não se constroem mais condomínios fechados de tipo "alternativo", nem mesmo nos padrões inferiores, que emulam os padrões recentes dos condomínios horizontais fechados de alto padrão. Do mesmo modo, em Goiânia praticamente não existe mais a ocorrência de construções de mansões ou palacetes - residências horizontais de alto padrão - fora desses mesmos condomínios horizontais fechados, de um modo que os condomínios fechados praticamente monopolizam a localização das construções de residências horizontais de alto padrão.

${ }^{147}$ Essa observação pôde ser realizada graças à já referida tipologia de critérios correspondentes de qualificação de condomínios horizontais fechados, realizada por Moura em Uberlândia. Sobre o condomínio fechado de alto padrão no estilo mais antigo, cf. Moura 2008: 184-186.
} 
O segundo exemplo é dado por Sharon Zukin (2004), que relacionou uma diferenciação estabelecida entre dois esquemas de qualificação de áreas centrais de Nova Iorque - que ela denomina de uma "contenda entre a paisagem e o vernáculo pelo espaço do centro da cidade" (Zukin 2004: 423) - a mudanças em padrões morfológicos de estabelecimentos comerciais. De acordo com a autora, "as áreas de lofts do centro da cidade formaram um mercado imobiliário especializado", porque "sua associação com os artistas investia diretamente os lofts com uma aura de autêntico consumo cultural" (idem). Os "artistas" tinham um alto potencial de atribuir valor aos imóveis, pois eram especialistas no lazer em tempo integral ou "técnicos da estética", "retratando e mobilizando as expectativas de outros consumidores com tempo parcial" (ibid.). Tratase, para a autora, de uma disputa de valores, cujo "elemento-chave" foi o fato de que os valores sociais dos "residentes da classe trabalhadora e dos pequenos manufatureiros" exerciam um "clamor mais fraco" do que os valores dos gentrificators, ou seja, dos "artistas" (ibid.: 423-424). O novo "padrão de legitimação do espaço urbano" prevaleceu, levando "os grandes proprietários de imóveis, os planejadores e os oficiais locais eleitos a perceberam que eles poderiam aumentar o valor econômico do centro ao propiciarem o consumo cultural". O novo conjunto de critérios também se tornou oficial, na medida em que os artistas contaram com a "legitimação por parte do Estado" de suas "reivindicações culturais do espaço urbano" (ibid.: 424). Essa institucionalização dos valores dos "artistas", como referência para a atuação dos agentes imobiliários e do Estado, "mudou a face do centro" de Nova Iorque ${ }^{148}$. Uma das conseqüências dessa mudança foi a transformação dos antigos "taprooms" em bares "ye olde" ou em "bistrôs "franceses"” (ibid.). Além da mudança no estilo dos bares, a autora nota uma mudança no estilo das lanchonetes, que é associada a mudanças nos padrões de sociabilidade de seus frequentadores. Ligadas aos antigos moradores da classe trabalhadora, as "cafeterias" da área observada por Zukin, "se tornaram tão obsoletas quanto a maioria das manufaturas do centro da cidade" (ibid.: 426). Em seu lugar, instalaram-se na região "Mcdonalds e stands de pizza", frequentados por clientes que, ao contrário dos antigos habitués das cafeterias, "são treinados para ver as lanchonetes mais como mercados de comida do que como lugares" (ibid.).

Minha leitura do texto de Zukin enfatiza a observação de que a mudança dos proprietários de certos tipos de imóveis está ligada a mudanças no contexto social de

\footnotetext{
148 "Essa mudança na paisagem material é paralela a uma mudança na forma como o centro da cidade é visto" (Zukin 2004: 427).
} 
atribuição de qualidade a estes elementos urbanos e nos estilos arquitetônicourbanísticos. Além disso, o estilo que prevaleceu no centro de Nova Iorque foi aquele que acabou por se beneficiar com a institucionalização da sua legitimação. Um imóvel tornado "obsoleto" é, portanto, um objeto desvalorizado em relação ao sistema de classificação dominante.

Como nos grupos delimitados por antropólogos urbanos na cidade de São Paulo, que se encontram nos "pedaços" do centro da cidade (Magnani 2007: 20), e que respondem a símbolos reconhecidos por seus integrantes, as linguagens dos códigos da cidade se referem a signos reconhecidos nas unidades fixas e móveis registradas no espaço físico da cidade. Mais do que conhecidas individualmente, as unidades são qualificadas com base em suas características morfológicas. Suas características podem ser consideradas positivas ou negativas em relação ao paradigma dominante, tais como os trajes no estilo hip-hop ou camisetas e bonés de times de futebol utilizados por um grupo de indivíduos, que podem indicar o momento de ter medo a um transeunte ou a um passageiro de ônibus, já que se trata de um grupo que pode utilizar a violência física ilegítima para dominar o espaço em um dado recorte de tempo. Os códigos são diversificados, desde o âmbito mais formal - o da lei do Estado, fiada na justiça e no monopólio da violência física legítima - até o seu âmbito mais informal, o da conversa cotidiana intra-familiar ou intra-círculo, moderada por regras informais de conversação e sociabilidade. Como já foi colocado, não se trata de um código urbano em comum, mas existe uma lógica em comum aos códigos que interessam a esta pesquisa: aquela da qualificação hierárquica dos elementos urbanos em função do paradigma de valor dominante. O paradigma dominante está relacionado aos padrões de uso e de apropriação do espaço urbano por grupos que, por uma atuação condizente com o mesmo paradigma dominante, podem ser considerados como parte ou todo de uma classe dominante do espaço urbano ${ }^{149}$.

149 Em A Distinção, Bourdieu relaciona as classes sociais aos estilos estéticos, enfatizando o papel "positivo" da classe dominante e o papel "negativo" das classes populares: "É evidente que nem todas as classes sociais estão preparadas e são levadas, em condições semelhantes, a entrar no jogo das recusas que rejeitam outras recusas, das superações que superam outras superações; além disso, as estratégias que visam transformar as disposições fundamentais de um estilo de vida em sistema de princípios estéticos, as diferenças objetivas em distinções eletivas, as opções passivas, constituídas em exterioridade pela lógica das relações distintivas, em tomadas de posição conscientes e eletivas, em opções estéticas, estão, de fato, reservadas aos membros da classe dominante e, até mesmo, à mais elevada burguesia, ou aos inventores profissionais da 'estilização da vida' que são os artistas - aliás, os únicos em condições de transformar sua arte de viver em uma das belas artes. Ao contrário, a entrada da pequena burguesia no jogo da distinção marca-se, entre outros indícios, pela ansiedade que suscita o sentimento de prestar-se à classificação ao entregar ao gosto dos outros indícios tão seguros do seu próprio gosto como as roupas, 
A dominação do espaço urbano nunca é total, pois os espaços utilizados exclusivamente pela classe dominada são por ela dominados. A classe dominada está presente no espaço como classe dominada no seu local de trabalho, mas não em seu local de moradia e nem mesmo em seu sistema exclusivo de transporte. Isso quer dizer que a classe dominada se apresenta como classe dominada nos espaços dominados de fato pela classe dominante e nos períodos de tempo em que essa dominação se faz efetiva. Mas, qualquer domínio que uma classe dominada obtenha sobre um espaço reservado a uma classe dominante é ilegítimo em relação ao paradigma dominante. Isso acontece, por exemplo, no caso do bairro do Morumbi, no sudoeste da cidade de São Paulo, onde em geral os imóveis que coexistem com os imóveis de alto padrão são aqueles em situação ilegal.

Nesse sentido, é importante ressaltar que o conceito de classe dominante do espaço urbano aqui utilizado é fundamentado nos termos da propriedade de uso do espaço qualificado como de alto padrão, e nos outros recursos disponibilizados para a manutenção e a garantia dessa propriedade legítima e legitimada pelo sistema de qualificação. Assim, a produção dos imóveis de alto padrão e o controle das áreas ocupadas pelos imóveis de alto padrão é geralmente feita de acordo com os interesses da classe dominante do espaço urbano ${ }^{150}$. Embora os políticos mais influentes e os produtores e especuladores imobiliários mais influentes sejam muitas vezes integrantes da classe dominante do espaço urbano, deve-se notar que é a classe dominante do espaço urbano, enquanto proprietária dos imóveis de alto padrão, que será de fato distinta ou distinguida por esses imóveis. Com isso, pode-se afirmar que os imóveis de alto padrão representam especificamente a classe dominante do espaço urbano ${ }^{151}$.

móveis ou um simples jogo de poltronas, como é o caso de um romance de Nathalie Sarraute. Quanto às classes populares, sua única função no sistema das tomadas de posição estética é, certamente, a de contraste e ponto de referência negativo em relação ao qual se definem, de negação em negação, todas as estéticas" (Bourdieu 2007: 57-58).

${ }^{150}$ Como notou Villaça (2001: 325).

${ }^{151}$ Sobre o poder econômico, recurso básico da classe dominante do espaço urbano, Bourdieu irá afirmar: "O poder econômico não reside na riqueza, mas na relação entre a riqueza e um campo de relações econômicas, cuja constituição é inseparável do desenvolvimento de um corpo de agentes especializados, dotados de interesses específicos; é nesta relação que a riqueza se encontra constituída, como capital isto é, enquanto um instrumento de apropriação de um equipamento institucional e de mecanismos indispensáveis ao funcionamento deste campo e, ao mesmo tempo, dos lucros que ele prodigaliza". (Bourdieu 2004:194). E também: "O poder econômico é, antes de tudo, o poder de colocar a necessidade econômica à distância: eis porque, universalmente, sua afirmação consiste na destruição de riquezas, no gasto ostentatório, no desperdício e em todas as formas do luxo gratuito. É assim que, tendo de transformar a existência inteira, à semelhança da aristocracia da corte, em uma exibição contínua, a burguesia constituiu a oposição entre pagante e gratuito, interesseiro e desinteressado, sob a forma da oposição - que, segundo Weber, é a sua característica própria - entre lugar de trabalho e moradia, dias úteis e feriados, exterior (masculino) e interior (feminino), negócios e sentimento, indústria e arte, mundo 
Aqui é possível apresentar a seguinte síntese: a classe dominante do espaço urbano é aquela que se apropria do espaço melhor qualificado na cidade, e por isso possui o direito de uso legítimo desse espaço. Os padrões de uso do espaço da classe dominante do espaço urbano orientam e são orientados pelos estilos arquitetônicourbanísticos da moda e pelo sistema de localização das unidades da estrutura urbana. Seus padrões de uso do espaço público e privado e seus padrões de gosto ou preferências estéticas e funcionais correspondem aos estilos arquitetônico-urbanísticos da moda. Seus padrões de deslocamento cotidiano são calculados pela quantificação hipotética de seus trajetos e constituem a referência para o sistema de localização. Essa quantificação é calculada em termos de acessibilidade, referente ao tempo de deslocamento entre imóveis, em trajetos efetuados pelos móveis estruturadores de alto padrão sobre um sistema viário.

Uma resposta para a questão acerca da dominação sobre o espaço urbano melhor qualificado pode ser então apresentada nos seguintes termos: é a classe dominante do espaço urbano que exerce de fato a dominação sobre as áreas onde se situam os imóveis de alto padrão dos quais se apropria. Sua dominação se faz na base do domínio da propriedade de uso legítimo do espaço urbano melhor qualificado. Esse domínio é legitimado pelo sistema de qualificação das unidades da estrutura urbana, que orienta a produção e a regulação dos imóveis de alto padrão por parte de outros agentes estruturadores.

\subsection{A quinta questão de pesquisa}

Se a classe dominante do espaço urbano se apropria dos imóveis de alto padrão e os critérios de qualificação das unidades da estrutura urbana, associados a essa apropriação, orientam a produção e a regulação dos imóveis de alto padrão, então os efeitos dessa dominação podem ser observados como efeitos da estruturação do espaço urbano por parte dos agentes estruturadores. Essa perspectiva leva a quinta e última questão de pesquisa a ser expressa nos seguintes termos: qual é o efeito da dominação do espaço urbano melhor qualificado pela classe dominante do espaço urbano?

\subsubsection{A disposição sincrônica e diacrônica dos imóveis de alto padrão}

da necessidade econômica e mundo da liberdade artística arrancado, pelo poder econômico, desta necessidade" (Bourdieu 2007:55). 
Como observado nos mapas de representação da estrutura urbana em Goiânia, o efeito da dominação do espaço urbano melhor qualificado se apresenta como uma disposição associada de imóveis de alto padrão. Trata-se da associação dos imóveis melhor qualificados intrinsecamente com as melhores localizações do sistema de localização, de modo que os imóveis melhor qualificados tendem a se situar nas melhores localizações.

Nesse ponto, a noção de segregação sócio-espacial proposta por esta pesquisa fica muito próxima da noção de que há uma correspondência entre a classe dominante do espaço urbano e a classe dominante do espaço social, bem como da noção de que há uma correspondência entre o espaço físico da cidade e o espaço social na cidade. Podese concluir que um espaço urbano corresponde a um espaço social e, na qualidade de espaço legitimado e legitimador, reforça as hierarquias do espaço social ${ }^{152}$. Como coloca Bourdieu, em A Produção da Crença, os campos tendem a se distribuir no espaço de Paris orientados de acordo com o espaço social como um todo, e não de acordo com suas próprias polarizações:

Pelo fato de que a distribuição dos agentes e instituições ligados às diferentes posições constitutivas de um campo particular não é aleatória, os ocupantes de posições dominantes nos diferentes campos que [sic] tendem a orientar-se em direção a posições dominantes (ou seja, ocupadas pelos dominantes) do espaço social, as distribuições espaciais dos diferentes campos tendem a sobrepor-se, como é o caso de Paris com a oposição, válida praticamente para todos os campos (com exceção das editoras, reagrupadas na rive gauche), entre a rive droite e a rive gauche (Bourdieu 2004: 38).

Nesse exemplo, como em outros já referidos, pode ser encontrada em Bourdieu a descrição de uma forma de segregação sócio-espacial similar àquela observada em um mapa da estrutura urbana da cidade de Goiânia, onde os imóveis de alto padrão de diversos tipos se encontram próximos uns dos outros e distantes dos imóveis de padrão inferior de diversos tipos ${ }^{153}$. Trata-se, no entanto, de uma representação ainda sincrônica da correspondência entre a estrutura urbana e a estrutura social, embora um padrão similar se apresente já na Paris do Segundo Império, como é mostrado em A Educação Sentimental.

Nas pesquisas de Villaça e dos estudiosos que desenvolveram os modelos de estrutura urbana adaptados para esta pesquisa, podem ser observados os efeitos de um

\footnotetext{
${ }^{152}$ E é "na relação entre a distribuição dos agentes e a distribuição dos bens no espaço que se define o valor das diferentes regiões do espaço social reificado" (Bourdieu 1999: 161).

${ }^{153}$ Assim como atividades específicas a um campo podem ser observadas no interior das áreas ocupadas por imóveis de alto padrão. No Setor Marista, na avenida 85 e na rua 9, por exemplo, se concentram lojas e fábricas de produtos têxteis que podem ser diferenciados daqueles de padrão inferior situados no bairro da Fama ou no bairro de Campinas.
} 
padrão similar de segregação sócio-espacial. Isso ocorre na medida em que, nas cidades norte-americanas e brasileiras pesquisadas por esses autores, os diversos imóveis de alto padrão também apresentaram uma tendência para se aproximar e a se distanciar dos diversos imóveis de padrão inferior. Além disso, esses estudos oferecem uma perspectiva diacrônica ou histórica do desenvolvimento das áreas segregadas, que se dá de acordo com o padrão geral de segregação sócio-espacial acima descrito.

Com a sobreposição dos mapas de Goiânia por períodos históricos, também ficou destacado nessa cidade o papel estruturador das áreas de concentração dos imóveis residenciais de alto padrão ${ }^{154}$. Em Goiânia, o comércio, os serviços, as atividades de lazer e os empregos das camadas de alta renda, foram atraídos em direção às áreas residenciais de alto padrão, como notaram Hoyt (1939: 108), Griffin e Preston (1966: 10) e Villaça (2001: 206; 282; 311), em outras cidades capitalistas. Pode-se afirmar que, em Goiânia, o centro comercial de alto padrão inicialmente se expandiu de modo bastante limitado, a partir do Setor Central e em direção ao sul e ao oeste. A partir dos anos 80, com a decadência do Setor Central e com o advento dos shopping-centers, o centro comercial de alto padrão "explodiu" em núcleos e faixas desconectados e situados sobre e entre antigas áreas residenciais de alto padrão com tendência à verticalização ${ }^{155}$. Nota-se que esses movimentos do centro e dos sub-centros comerciais de alto padrão sempre se deram em direção às áreas residenciais de alto padrão. Por outro lado, a expansão histórica das áreas residenciais de alto padrão teve limites, pois essas áreas nunca estiveram situadas distantes das áreas não-residenciais de alto padrão ${ }^{156}$. Em Goiânia, a frente de expansão dos imóveis de alto padrão sempre foi caracterizada por loteamentos residenciais horizontais de alto padrão, e sempre ocupou vazios urbanos situados o mais próximo o possível das áreas já ocupadas por imóveis associados de alto padrão. Isso quer dizer que existe uma atração mútua entre os diferentes tipos de imóveis de alto padrão.

\footnotetext{
154 Além da atração exercida sobre loteamentos residenciais projetados para clientes de renda média, notada também por Hoyt nos Estados Unidos, como já foi referido. É preciso destacar que Villaça também observa a atração da classe média pelos imóveis de alto padrão, o que mostra que tal tendência ocorre também em outras cidades brasileiras além de Goiânia (Villaça 2001: 312).

${ }^{155}$ As edificações públicas que podem ser mais bem qualificadas (como monumentais) também seguiram a mesma direção, como pode ser constatado pela presença de edifícios como o Paço Municipal e o Centro Cultural Oscar Niemeyer nas proximidades do novo setor de imóveis de alto padrão que se desenvolveu na parte sudeste da cidade a partir do início do século XXI.

${ }^{156}$ Nos condomínios horizontais fechados de Goiânia, a "distância do centro" é um dos fatores negativos mais apontados nas pesquisas de opinião observadas (Cf. Silva 2003; Campos 2007).
} 
Os resultados empíricos apresentados por esta pesquisa estão desse modo de acordo com a constatação de Villaça, de que há nas metrópoles brasileiras uma atração mútua entre o centro comercial de alto padrão - entendido como a principal concentração de imóveis não-residenciais de alto padrão - e as áreas residenciais de alto padrão:

As classes de mais alta renda escolhem a direção de crescimento, em função dos atrativos do sítio - como também concluiu Hoyt - e também, e principalmente, em função da simbiose, da "amarração" que desenvolvem com suas áreas de comércio, de serviços e emprego, ou seja, em virtude de sua inserção na estrutura urbana que elas próprias produzem (...) (Villaça 2001: 320).

E adiante:

Talvez o processo mais notável de produção do espaço sob o comando das camadas de mais alta renda seja a inter-relação que elas e seus bairros residenciais mantêm com os centros principais. Quanto mais essas camadas se concentram em uma determinada região da cidade, mais elas procuram trazer para essa mesma região importantes equipamentos urbanos. Quanto mais o conseguem, mais vantajosa essa região se torna para aquelas camadas e mais difícil se torna, para elas, abandonar essa direção de crescimento (idem: 321).

As constatações empíricas similares às de Villaça foram possíveis através do uso do método descritivo e cartográfico. Com o método foi possível descrever em Goiânia um padrão recorrente de segregação sócio-espacial, na forma de uma concentração de diferentes tipos de usos do solo de alto padrão, relacionados em diferentes escalas e tipos de associação ${ }^{157}$.

Por sua vez, a sobreposição dos mapas mostrou uma dinâmica de expansão e de deslocamento dessa concentração de imóveis de alto padrão, o que levou à suposição de que um mesmo padrão de segregação sócio-espacial se manteve ao longo de toda a história de Goiânia. Nessa dinâmica houve mudanças no ritmo de desenvolvimento dos imóveis associados de alto padrão, mas essas mudanças não modificaram a lógica geral da segregação sócio-espacial descrita.

Se o padrão sincrônico de disposição dos imóveis de alto padrão é o de uma associação entre as melhores localizações e os melhores exemplares dos estilos arquitetônico-urbanísticos da moda, o padrão de desenvolvimento histórico dessa disposição recorrente é o de uma sucessão de processos de estruturação dos melhores exemplares dos estilos arquitetônico-urbanísticos da moda em torno das melhores

\footnotetext{
${ }^{157}$ Que, como foi mostrado, foi descrita nas escalas dos núcleos, dos setores e do centro ampliado.
} 
localizações. Como já foi mostrado, são os imóveis estruturadores que oferecem a outros imóveis uma posição melhor ou pior em um sistema de localização urbano.

\subsubsection{Os imóveis estruturadores}

Nas passagens mostradas acima, Villaça, ao afirmar a simbiose entre as áreas residenciais e não-residenciais de alto padrão, oferece a chave para a explicação do papel dos imóveis estruturadores como elementos apropriados pela classe dominante do espaço urbano, que por isso são atuantes sobre o processo geral de estruturação sócioespacial.

Como foi colocado, o padrão geral de configuração das áreas apropriadas pela classe dominante do espaço urbano é uma disposição associada dos imóveis melhor qualificados intrinsecamente com as melhores localizações do sistema de localização, de modo que os imóveis melhor qualificados tendem a se situar nas melhores localizações. As melhores localizações são definidas em termos de acessibilidade, aferida em relação aos imóveis estruturadores melhor qualificados, que por sua propriedade de conferir uma alta qualidade de localização a outros imóveis, tendem a atrair para suas proximidades os imóveis de alto padrão. De acordo com Villaça, as classes de alta renda - que esta pesquisa associa à classe dominante do espaço urbano escolhem os locais que irão ocupar em função dos "atrativos do sítio" e em função da "simbiose" entre suas moradias e seus locais de trabalho, lazer e convívio social. No que diz respeito à simbiose, Villaça associa o efeito qualitativo que a proximidade de um sistema de transporte, do comércio e de serviços adequados exerce sobre as residências de alto padrão. De acordo com o autor, a proximidade desses imóveis transmite para a classe dominante que habita suas redondezas a sensação de estar "perto de tudo", enquanto a distância desses imóveis transmite a sensação de se estar "fora de mão" (Villaça 2001: 203). Por outro lado, outros imóveis estruturadores - parques, praças, jardins, praias, condomínios residenciais bem equipados, etc. - irão transmitir aos ocupantes de suas redondezas uma sensação de tranqüilidade, de conforto e de se estar "perto da natureza", como enfatizam diversos anúncios publicitários de imóveis de alto padrão e como foi observado nas entrevistas realizadas com moradores de condomínios fechados e de edifícios verticais de alto padrão. Dessas entrevistas, retirei a noção de 
"qualidade de vida", associada à aprazibilidade conferida pela proximidade de um imóvel estruturador ${ }^{158}$.

Os já referidos núcleos e faixas de imóveis de alto padrão são exemplos típicos de nucleação em torno de imóveis estruturadores que podem ser observados em Goiânia. Os núcleos são formados pela disposição de imóveis de alto padrão em torno de imóveis estruturadores tais como praças ou parques, enquanto as faixas são formadas pela disposição de imóveis de alto padrão dispostas em torno de ruas ou avenidas. $\mathrm{Na}$ frente de expansão dos imóveis de alto padrão, os imóveis estruturadores típicos são os loteamentos cujas características e cuja localização é propícia para a instalação de edificações de alto padrão em seus terrenos. Atualmente, a forma típica dos loteamentos horizontais de alto padrão é a dos condomínios fechados, que encerram em seus muros elementos paisagísticos e urbanísticos considerados aprazíveis.

Tipos diferentes de imóveis de alto padrão são estruturados por tipos diferentes de imóveis estruturadores. Assim, os vazios urbanos localizados diante dos bairros residenciais de alto padrão já estabelecidos em Goiânia atraíram ao longo da história os loteamentos de alto padrão, por oferecerem a localização funcionalmente mais apropriada para a produção de um novo lugar aprazível, na forma de um bairro-jardim ou, mais recentemente, na forma de um condomínio fechado. Por outro lado a avenida República do Líbano, no Setor Oeste, amplo bulevar em um bairro de alto valor do solo, atraiu os melhores hotéis construídos na cidade nas décadas de 80 e $90^{159}$. Um bulevar bem arborizado e bem localizado, tal como a avenida República do Líbano dos anos 80 e a avenida Goiás dos planejadores de Goiânia, conjuga em um mesmo imóvel estruturador as vantagens da aprazibilidade e da acessibilidade.

Muitos outros exemplos de estruturação podem ser dados pela análise da estrutura urbana. Um exemplo notável, o já referido caso da valorização dos terrenos em torno dos parques urbanos de Goiânia, mostra que a sensação de aprazibilidade conferida por um parque urbano pode ser apreciada de modo diferente por grupos

\footnotetext{
${ }^{158}$ Trata-se de argumentos recorrentes indicados também em várias pesquisas acadêmicas consultadas, tais como a idéia de tranqüilidade, a sensação de "estar perto da natureza", o prazer de "ouvir os pássaros" e de "estar longe do tumulto". Nas entrevistas com moradores de condomínios fechados, os temas da segurança e do medo, por outro lado, não foram destacados. Mas isso não quer dizer que tais temas não sejam também recorrentes ou aceitos. É possível que os entrevistados não se sintam tão à vontade para lidar com esses temas em uma entrevista direta e gravada com um sociólogo, como se sentem à vontade para falar das vantagens da aprazibilidade. No entanto, não penso que a "fala do crime" se oponha à idéia de aprazibilidade. Ao contrário, ela subsidia um modelo de lugar aprazível fechado.

${ }^{159}$ Só recentemente estão sendo construídos novos hotéis de padrão semelhante aos dos hotéis da avenida República do Líbano. As novas construções se concentram no novo distrito de alto padrão, na parte sudeste da cidade.
} 
sociais diferentes, já que nos bairros de baixo padrão, a produção de parques urbanos de acordo com o mesmo modelo utilizado nas partes centrais da cidade - mas não com a mesma qualidade - não surtiu os mesmo efeitos de valorização da localização. Também as demandas das associações de moradores podem ser diferenciadas quanto aos grupos sociais que habitam um bairro, pois enquanto as associações de moradores dos bairros da periferia lutam pela instalação ou melhorias imóveis estruturadores que oferecem vantagens funcionais em áreas desprovidas desse tipo de benefícios ${ }^{160}$, algumas associações de moradores de bairros de alto padrão lutam contra a instalação de imóveis estruturadores funcionais, para defender a aprazibilidade conferida por seus bairros ${ }^{161}$.

Assim, pode-se dizer que o que os imóveis estruturadores oferecem em termos de qualidade positiva a outros imóveis, pode ser definido em termos de funcionalidade e de aprazibilidade, aferida em termos de acessibilidade. Essas vantagens atribuídas aos agentes garantem a atração dos imóveis estruturadores sobre os imóveis de alto padrão. A estruturação de imóveis de alto padrão em torno de imóveis estruturadores pode ser então explicada em termos das vantagens oferecidas aos moradores de suas redondezas. Essas vantagens são funcionais ou aprazíveis e assim ligadas respectivamente à sensação de "estar perto de tudo" e à sensação de obter uma maior "qualidade de vida". Essas duas vantagens de localização não são essencialmente dicotômicas ou opostas, e podem ser atribuídas em diversas escalas de classificação dos elementos da estrutura urbana, mas respondem pela atração que os imóveis estruturadores exercem sobre a classe dominante do espaço urbano em primeiro grau e sobre os imóveis de alto padrão em segundo grau.

Voltando à esquematização já efetuada do sistema de localização como parte integrante do sistema de qualificação das unidades da estrutura urbana, posso afirmar que a qualidade de localização, que é calculada em termos de acessibilidade - o cálculo de trajetos hipotéticos - se faz com base em dois tipos relativamente opostos e relativamente complementares de esquemas de qualificação da localização, o esquema da funcionalidade, que qualifica a proximidade de elementos estruturadores tais como centros e sub-centros comerciais, e o esquema da aprazibilidade, que qualifica a proximidade de imóveis estruturadores tais como parques, praças ou praias.

\footnotetext{
${ }^{160}$ Sobre o papel de associações de moradores na periferia de Goiânia, cf. Chaves 1985, Bernardes 1989, Moysés 1998 e Fonseca 2008.

${ }^{161}$ Como ocorreu em São Paulo com os recentes protestos de moradores do Morumbi contra a instalação do novo trem elevado que cortará o bairro. Nas pesquisas sobre condomínios fechados em Goiânia, já referidas, ficou destacado o papel das associações de moradores.
} 
Pode-se afirmar aqui que a dinâmica de reprodução do padrão verificado $e$ recorrente de disposição dos imóveis de alto padrão foi regulada pela atração que os imóveis estruturadores exercem sobre os agentes que determinam a localização dos imóveis de alto padrão.

\subsubsection{As forças centrífugas e centrípetas}

Se a estruturação dos imóveis de alto padrão se dá em torno de imóveis estruturadores, é através do uso, da qualificação, da regulação, da localização e da produção de imóveis estruturadores que pode ser compreendida a dinâmica do desenvolvimento das áreas segregadas de alto padrão. O que dá a esses processos de estruturação dos imóveis de alto padrão um caráter de forças centrípetas e centrífugas é a inserção de novos imóveis estruturadores na estrutura urbana.

A inserção de imóveis estruturadores se dá por sua classificação no sistema de qualificação das unidades da estrutura urbana, por sua regulação pelo Estado, por sua apropriação e uso pela classe dominante do espaço urbano, e pelo volume e localização da sua produção. Se novos imóveis estruturadores são produzidos, utilizados e classificados em quantidade importante, e são situados distantes ou relativamente distantes do centro principal da cidade, apresentam-se forças de estruturação centrífugas em relação a esse centro principal. Se não há uma produção e um uso de novos imóveis estruturadores por parte da classe dominante do espaço urbano, a situação se mantém estável. Mas, se antigos imóveis estruturadores "degradados" - fora de moda e apropriados por agentes hierarquicamente inferiores - são "revitalizados" - postos de volta à moda e reapropriados pela classe dominante -, então a dinâmica de estruturação dos imóveis de alto padrão se apresenta na forma de forças centrípetas. Portanto, essas forças estruturadoras de longa escala são centrípetas e centrífugas quando tomadas em relação à sua distância das antigas áreas associadas de alto padrão, que correspondem ao setor - no sentido de Hoyt - dos imóveis de alto padrão, ou ainda ao centro da cidade, no sentido da distinção centro-periferia ${ }^{162}$.

A produção, a qualificação, o uso, a localização e a regulação dos imóveis estruturadores, orientados pelo sistema de qualificação das unidades da estrutura urbana, e a utilização dos imóveis estruturadores pela classe dominante do espaço urbano,

${ }^{162}$ Em Goiânia, onde o processo de "retorno ao centro" não é relevante, ainda é possível estabelecer uma distinção sócio-espacial entre o setor "hoytiano" e o centro como uma zona concêntrica, pois os imóveis situados no interior do setor de alto padrão são ainda distintos, por maior qualidade geral e maior valor de mercado, dos imóveis de padrão médio situados em áreas adjacentes ao setor de alto padrão. Essas áreas de padrão médio se situam internas ao círculo central, assim como o setor de alto padrão. Cf. figura 52. 
moldam assim a forma de inserção desses imóveis na estrutura urbana. Dada a atração exercida pelos imóveis estruturadores sobre os imóveis de alto padrão, a forma de inserção dos imóveis estruturadores na estrutura urbana afeta a dinâmica de desenvolvimento das áreas associadas de alto padrão. Com isso, pode-se afirmar que $o$ volume e a localização da inserção dos imóveis estruturadores na estrutura urbana são responsáveis pelas forças centrípetas e centrífugas de estruturação dos imóveis de alto padrão.

\subsubsection{Os fatores de inserção}

Se a inserção dos imóveis estruturadores na estrutura urbana é responsável pelo aspecto dinâmico da estruturação dos imóveis de alto padrão, então é preciso se ater aos fatores que determinam essa inserção. Os fatores de inserção dos imóveis estruturadores são aqueles que afetam a qualificação, o uso, a produção, a localização e a regulação dos imóveis estruturadores. Entre os fatores de inserção identificados na pesquisa empírica e na bibliografia pesquisada, podem ser citados: (a) o crescimento, estagnação ou diminuição numérica da classe dominante do espaço urbano, associados aos índices demográficos e econômicos; (b) a situação econômica geral da sociedade e a situação econômica específica da classe dominante do espaço urbano, que podem estimular ou desestimular o assim chamado "boom imobiliário"; (c) a articulação entre os agentes estruturadores dominantes, ou seja, o contexto específico de relações entre o Estado, os produtores e especuladores imobiliários, e a classe dominante do espaço urbano; (d) as mudanças no papel específico do Estado sobre a legislação e o controle da estruturação urbana; (e) as mudanças na composição e nos hábitos da classe dominante do espaço urbano; (f) as mudanças nos móveis estruturadores, tais como a disseminação histórica do uso do automóvel ou o crescente uso de bicicletas pela classe dominante do espaço urbano, que são mudanças associadas a mudanças no sistema viário; (g) mudanças nos estilos arquitetônico-urbanísticos da moda e no sistema de localização. Empiricamente, os fatores podem ser aferidos em termos de sua influência sobre a inserção de imóveis estruturadores na estrutura urbana.

É preciso destacar aqui que esses fatores afetam somente o volume e a localização da inserção dos imóveis estruturadores, mas não modificam a lógica geral da dominação do espaço urbano. A mesma tendência de disposição dos imóveis de alto padrão em torno dos imóveis estruturadores, que atribuem melhores localizações, se manteve ao longo de toda a história de Goiânia. 
Como a dinâmica do processo de estruturação não modificou o padrão disposição básico e recorrente de disposição dos imóveis de alto padrão na estrutura urbana de Goiânia, pode-se afirmar que essa disposição básica, que atravessa toda a história da cidade, é a forma correspondente da estrutura física da cidade em relação à estrutura social estabelecida na mesma cidade. Essa forma de correspondência, como já foi colocado, é resultante da dominação do espaço urbano, uma dominação orientada ao grupo social que é correspondente e é distinguido pelos imóveis de alto padrão, a classe dominante do espaço urbano.

O ponto final que esta pesquisa alcançou é na verdade simples, evidente, conhecido e reconhecido, embora nem sempre assumido: enquanto o mercado imobiliário regular a distribuição dos imóveis e enquanto houverem lugares mais desejados que outros, haverá a segregação por renda e a classe dominante do espaço urbano será, antes de tudo, uma classe de renda. Mesmo em uma sociedade sem mercado imobiliário, enquanto houverem imóveis melhor qualificados cuja distribuição é controlada e restrita a grupos determinados, haverá alguma forma de correspondência entre a hierarquia social e a estrutura urbana e haverá alguma forma de segregação sócio-espacial.

A quinta e última questão de pesquisa pode ser aqui respondida nos seguintes termos: o processo básico de estruturação dos imóveis de alto padrão em Goiânia se manifestou ao longo de toda a história da cidade sob a forma de uma atração exercida pelos imóveis estruturadores sobre os imóveis de alto padrão. Os fatores responsáveis pela inserção dos imóveis estruturadores na estrutura urbana, embora exerçam uma determinação sobre o estado da dinâmica de transformação das áreas ocupadas pelos imóveis de alto padrão, não modificaram a disposição básica de segregação sócioespacial. Na qualidade de espaço urbano apropriado, as áreas de alto padrão correspondem e representam a segregação social imposta pela classe dominante do espaço urbano.

\section{Conclusão}

\subsection{A explicação da hipótese de pesquisa}

É possível agora oferecer uma explicação sintética da hipótese de pesquisa, levantada pela adaptação e aplicação do método descritivo e cartográfico de análise da 
estrutura urbana. A hipótese de pesquisa foi formulada da seguinte maneira: um processo histórico e específico de segregação sócio-espacial pode ser representado pelo método descritivo e cartográfico porque há, ao menos no tempo e espaço estudados, uma correspondência entre o espaço físico e o espaço social.

Para explicar a hipótese de pesquisa foi desenvolvida uma sequência de cinco questões de pesquisa. O conjunto da explicação resultou na hipótese final.

a) Primeira questão de pesquisa: como se dá a correspondência entre o espaço físico e o espaço social?

Essa correspondência se dá pela lógica da distinção: as unidades que compõem a estrutura urbana distinguem os agentes que ocupam o espaço urbano. Por essa propriedade de distinção, as unidades da estrutura urbana podem corresponder à posição dos agentes no espaço social.

b) Segunda questão de pesquisa: Como se dá a distinção dos agentes pelas unidades da estrutura urbana?

A distinção dos agentes pelas unidades da estrutura urbana se dá pela qualificação coletivamente reconhecida das unidades pelos agentes. Essa qualificação é processada pela operação de critérios de qualificação. Os critérios de qualificação podem se inserir em esquemas formais e informais de qualificação das unidades da estrutura urbana. Três características compartilhadas pelos critérios de qualificação irão integrar os esquemas de qualificação dos imóveis urbanos em um sistema de qualificação dos imóveis urbanos. Essas características são:

1 - a correspondência entre os critérios, de modo que os diversos critérios de qualificação podem ser reconhecidos como um conjunto de elementos correspondentes, ou um estilo arquitetônico-urbanístico;

2 - a conversibilidade dos diversos critérios de qualificação das unidades da estrutura urbana em valor financeiro, de modo que critérios positivos ou negativos serão conversíveis, respectivamente, em maior e menor valor financeiro;

3 - a universalidade do reconhecimento dos diversos critérios de qualificação da estrutura urbana, de um modo que relaciona os critérios de qualificação das unidades da estrutura urbana a um paradigma cultural dominante, na medida em que tais critérios são amplamente aceitos no meio social.

O sistema de qualificação atribui qualidade a um imóvel pelas suas próprias características ou pela proximidade com outros imóveis, os imóveis estruturadores. O primeiro tipo de atribuição define a qualidade intrínseca de um imóvel e o segundo tipo 
de atribuição define a qualidade extrínseca de um imóvel. A qualidade intrínseca de um imóvel é tomada em referência aos estilos arquitetônico-urbanísticos da moda e a qualidade extrínseca de um imóvel resulta de sua inserção em um sistema de localização. O sistema de qualificação comporta assim os estilos arquitetônicourbanísticos da moda e um sistema intra-urbano de localização.

Portanto, pode-se afirmar que a distinção dos agentes pelas unidades da estrutura urbana se dá através da classificação dessas unidades em um sistema coletivamente aceito de qualificação da estrutura urbana.

c) Terceira questão de pesquisa: Qual é o efeito do sistema de qualificação da estrutura urbana?

O efeito do sistema de qualificação da estrutura urbana é a atribuição universal de legitimidade à dominação do espaço urbano. O que está inscrito no sistema de qualificação da estrutura urbana é a lógica da dominação do espaço urbano, que é exercida pelos agentes estruturadores dominantes, os quais controlam, produzem e se apropriam do espaço urbano melhor qualificado. Os três grupos de agentes estruturadores dominantes identificados são o Estado, os produtores imobiliários especializados em imóveis de alto padrão e a classe dominante do espaço urbano.

d) Quarta questão de pesquisa: Como os grupos de agentes estruturadores dominantes exercem a dominação do espaço urbano?

O procedimento geral de dominação do espaço urbano é garantido pelo poder regulatório do Estado e pela conversibilidade dos critérios de qualificação em valor monetário, o que permite aos detentores do capital financeiro a aquisição, a manutenção, a produção e os direitos de uso das propriedades imobiliárias melhor qualificadas no sistema de qualificação e, portanto, capazes de atribuir a distinção aos seus proprietários e usuários.

É possível estabelecer uma relação entre os grupos de agentes estruturadores dominantes e seus meios de dominação. O Estado detém o monopólio formal do poder de regulação e controle sobre a produção e o uso do espaço urbano; os produtores imobiliários se valem da propriedade fundiária e do capital financeiro para a produção dos imóveis; e a classe dominante do espaço urbano se vale da propriedade imobiliária, do capital financeiro e dos padrões de gosto para dominar os estilos arquitetônicourbanísticos da moda, assim como se vale da propriedade imobiliária, do capital financeiro e dos móveis estruturadores para dominar o sistema de localização. 
Os agentes estruturadores do espaço urbano melhor qualificado exercem seu poder estruturador orientados pelo sistema de qualificação das unidades da estrutura urbana. Os critérios positivos do sistema de qualificação são especificamente relacionados à classe dominante do espaço urbano, em um sentido hierárquico no qual essa categoria específica de agentes estruturadores se associa às unidades melhor qualificadas. Assim, a produção e a regulação das áreas ocupadas por imóveis de alto padrão são efetuadas de acordo com os interesses da classe dominante do espaço urbano.

A classe dominante do espaço urbano é aquela que se apropria do espaço melhor qualificado na cidade, e por isso possui o direito de uso legítimo desse espaço. Os padrões de uso do espaço da classe dominante do espaço urbano orientam - e são orientados - os estilos arquitetônico-urbanísticos da moda e o sistema de localização, que se inscrevem no sistema de qualificação da estrutura urbana. A influência da classe dominante do espaço urbano sobre a produção imobiliária de alto padrão e sobre o poder regulatório do Estado pode ser observada com base nesses dois aspectos. Seus padrões de uso do espaço público e privado e seus padrões de gosto ou preferências estéticas e funcionais correspondem aos estilos arquitetônico-urbanísticos da moda. Seus padrões de deslocamento cotidiano são calculados pela quantificação de seus trajetos e constituem a referência para o sistema de localização. Essa quantificação é calculada em termos de acessibilidade, referente ao tempo de deslocamento entre imóveis, em trajetos efetuados pelos móveis estruturadores sobre um sistema viário.

Pode-se afirmar, portanto, que é a classe dominante do espaço urbano que exerce de fato a dominação sobre as áreas onde se situam os imóveis de alto padrão dos quais se apropria. Sua dominação se faz na base de um domínio da propriedade de uso do espaço urbano legitimado pelo domínio do sistema de qualificação das unidades da estrutura urbana, que orienta a produção e a regulação dos imóveis de alto padrão por parte de outros agentes estruturadores. É a classe dominante do espaço urbano que é distinta ou distinguida pela propriedade e pelo uso dos imóveis de alto padrão, e não os demais agentes estruturadores dominantes - embora, claro, estes sejam, em grande parte, integrantes da classe dominante do espaço urbano.

e) Quinta questão de pesquisa: Qual é o efeito da dominação do espaço urbano melhor qualificado pela classe dominante do espaço urbano?

O efeito da dominação do espaço urbano melhor qualificado pela classe dominante do espaço urbano é um padrão específico de estruturação das áreas por ela 
apropriadas, onde são produzidos os imóveis de alto padrão. Esse efeito de dominação pode ser representado pelo método descritivo e cartográfico porque corresponde a um processo específico de segregação social. O padrão geral é uma disposição associada dos imóveis melhor qualificados intrinsecamente com as melhores localizações do sistema de localização, de modo que os imóveis melhor qualificados tendem a se situar nas melhores localizações. As melhores localizações são definidas em termos de acessibilidade, aferida em relação aos imóveis estruturadores melhor qualificados, que por sua propriedade de conferir uma alta qualidade de localização a outros imóveis, tendem a atrair para suas proximidades os imóveis de alto padrão.

As vantagens de funcionalidade e de aprazibilidade, conferidas pelos imóveis estruturadores a outros imóveis dispostos ao seu redor, determinam a capacidade desses imóveis de qualificar positivamente uma localização e, portanto, seu poder de atração sobre os imóveis de alto padrão. A classificação, a produção, a localização e a regulação de imóveis estruturadores, orientadas pelo sistema de qualificação das unidades da estrutura urbana, bem como a utilização dos imóveis estruturadores pela classe dominante do espaço urbano, determinam o ritmo de inserção de novos imóveis estruturadores na estrutura urbana. Dado o poder de atração dos imóveis estruturadores, a sua disposição na estrutura urbana é responsável pelas forças centrípetas e centrífugas de estruturação dos imóveis de alto padrão. Os imóveis estruturadores distantes das partes centrais da cidade exercem forças centrífugas, e os imóveis estruturadores localizados nas partes centrais da cidade exercem forças centrípetas sobre os imóveis de alto padrão.

São diversos os fatores identificados que afetam a qualificação, a localização, o uso, a produção e a regulação dos imóveis estruturadores e, portanto, afetam a dinâmica das forças centrípetas e centrífugas de estruturação dos imóveis de alto padrão: o crescimento numérico da classe dominante do espaço urbano; a situação econômica geral e específica da classe dominante do espaço urbano; a articulação entre os agentes estruturadores; as mudanças no papel do Estado; as mudanças na configuração da classe dominante do espaço urbano; as mudanças nos móveis estruturadores e nos estilos arquitetônico-urbanísticos da moda, correspondentes às mudanças nos padrões de uso e nos padrões de gosto da classe dominante do espaço urbano e às mudanças nos padrões de produção de imóveis de alto padrão. Apesar dessa diversidade de fatores, a mesma tendência de disposição dos imóveis de alto padrão em torno dos imóveis estruturadores que atribuem as melhores localizações se manteve ao longo de toda a história de 
Goiânia. Esses fatores de inserção, portanto, afetam somente o ritmo das mudanças, mas não modificam a lógica geral da dominação do espaço urbano.

Pode-se afirmar, portanto, que o processo básico de estruturação dos imóveis de alto padrão em Goiânia foi o da atração exercida pelos imóveis estruturadores sobre os imóveis de alto padrão, e que os fatores que geram e transformam os imóveis estruturadores são responsáveis pela dinâmica de transformação das áreas ocupadas pelos imóveis de alto padrão. Essa dinâmica de transformação, em escala ampliada, se manifestou na forma de uma interação entre forças centrífugas e centrípetas em relação à parte central da cidade. Na qualidade de espaço urbano melhor qualificado e mais valorizado, as áreas de alto padrão correspondem e representam, na estrutura física da cidade, a segregação social imposta pela classe dominante do espaço urbano.

\subsection{Hipótese final}

A disposição concentrada dos imóveis de alto padrão descrita pelo método descritivo e cartográfico de representação da estrutura urbana é um efeito da dominação das áreas melhor qualificadas da cidade pela classe dominante do espaço urbano. $\mathrm{O}$ efeito da dominação garantiu a correspondência entre os imóveis de alto padrão e a classe dominante do espaço urbano ao longo de toda a história de Goiânia. As permanências e mudanças nos padrões de disposição desses imóveis, resultantes da relação de forças centrípetas e centrífugas de estruturação em torno de imóveis estruturadores, são as formas temporárias que essa correspondência apresentou e apresenta, o que não modificou a lógica básica de segregação sócio-espacial.

\subsection{O método sociológico de análise da dominação do espaço urbano}

A esquematização teórica apresentada neste trabalho deve ser tomada como uma orientação para uma pesquisa empírica e ser realizada posteriormente, como uma pesquisa de doutorado. Assim, as categorias de análise desenvolvidas são voltadas para a investigação empírica, e constituíram a base para a concepção de um método propriamente sociológico para a análise da dominação do espaço. $\mathrm{O}$ objetivo de longo prazo é o desenvolvimento do método aqui apresentado e sua aplicação na cidade de Goiânia e, se possível também em outra cidade, de modo a possibilitar um estudo 
comparativo capaz de testar a validade do método, bem como de encaminhar uma tentativa de demonstração da hipótese final, acima apresentada.

No processo de adaptação e aplicação do método descritivo e cartográfico de representação da estrutura urbana e de demonstração da hipótese de pesquisa, que resultou na elaboração desta dissertação de mestrado, foi coletado um corpo considerável de material empírico e acadêmico relativo à cidade de Goiânia, de modo que a hipótese final acima postulada e o método aqui apresentado são embasados nesse material. De acordo com o objetivo de longo prazo de aplicação de um método sociológico de análise da dominação do espaço urbano, esse material coletado será reaproveitado e reavaliado, em conjunto com outras aquisições empíricas. Até o momento, a cidade de São Paulo foi escolhida para ser a outra cidade a ser analisada em um estudo comparativo. Essa escolha é justificada por ser a cidade o foco principal de questionamento nos seminários de sociologia urbana realizados no CERU, dos quais faço parte. Além disso, já foi coletado material empírico e acadêmico sobre essa cidade.

O método sociológico de análise da dominação do espaço é apresentado aqui de maneira esquemática e resumida. Ele deverá ser posteriormente desenvolvido e modificado, com o desenvolvimento de sua aplicação e de sua orientação para a interpretação de material empírico. Os procedimentos metodológicos que compõem o método serão apresentados de acordo com o desenvolvimento da explicação da hipótese de pesquisa, que corresponde à parte 4 desta dissertação e que foi apresentada em síntese no início desta conclusão.

\subsubsection{Primeiro procedimento de pesquisa}

O primeiro procedimento de análise consiste na aplicação do método descritivo e cartográfico de representação da estrutura urbana. A aplicação do método cartográfico será orientada pela noção de estrutura urbana utilizada nesta pesquisa, uma estrutura composta de unidades, subdivididas em agentes - indivíduos e grupos - e objetos móveis e imóveis. Como parte inicial da aplicação do método sociológico de análise da dominação do espaço urbano, o método descritivo de análise da estrutura urbana visa identificar, delimitar e qualificar os imóveis de alto padrão, associados em diferentes escalas.

O uso do método descritivo e cartográfico se dá pelo procedimento dos seguintes passos de pesquisa: (a) identificação de imóveis, (b) qualificação dos imóveis, 
(c) categorização descritiva dos imóveis, (d) periodização, (e) escalonamento e (f) identificação de práticas de sociabilidade associadas aos imóveis de alto padrão.

O resultado da aplicação do método cartográfico será apresentado na forma de mapas da estrutura urbana de Goiânia, apresentados por período histórico e focados na representação dos imóveis de alto padrão.

\subsubsection{Segundo procedimento de pesquisa}

O segundo procedimento analítico dessa pesquisa é a investigação do sistema de qualificação das unidades da estrutura urbana. Nesse ponto, é investigada a prática da qualificação das unidades da estrutura urbana pelos agentes.

Como a prática da qualificação é uma atividade significativa e discursiva complexa, trata-se de delimitar parcialmente o sistema de classificação do espaço urbano em relação à correspondência, conversibilidade e universalidade dos critérios de qualificação operados pelos agentes.

Sob esse viés serão analisadas fontes que possam indicar os critérios que atribuem qualidades aos elementos da estrutura urbana. O material referente ao planejamento urbano, o material jornalístico e publicitário, o material acadêmico e a realização e análise de entrevistas e depoimentos são indicados para essa etapa.

\subsubsection{Terceiro procedimento de pesquisa}

O terceiro procedimento de pesquisa tem como meta realizar uma identificação dos grupos de agentes estruturadores dominantes do espaço urbano. A identificação empírica dos grupos de agentes dominantes se faz com base na avaliação da capacidade de interferência dos agentes sobre a disposição das unidades da estrutura urbana. $\mathrm{O}$ foco principal se refere ao poder de estruturação específico sobre a estruturação dos imóveis de alto padrão.

Aqui o material acadêmico é destacado como fonte principal de pesquisa, por oferecer detalhes sobre o papel dos agentes na estruturação do espaço urbano que podem ser desdobrados em uma perspectiva histórica, de modo a indicar mudanças no papel dos agentes e indicar a constituição de grupos e classes específicos.

\subsubsection{Quarto procedimento de pesquisa}

O quarto procedimento de pesquisa proposto consiste na identificação empírica dos recursos de dominação de que se valem os agentes estruturadores dominantes do espaço urbano. Os grupos de agentes estruturadores dominantes serão nesse ponto 
associados aos meios que disponibilizam para exercer o controle da disposição das unidades da estrutura urbana e, em particular, dos imóveis de alto padrão.

$\mathrm{O}$ poder regulatório e jurídico, o capital financeiro, a propriedade fundiária e os móveis estruturadores, estes associados a um sistema viário correspondente, devem ser observados em relação aos grupos de agentes que os disponibilizam, utilizando-os como meios de apropriação e de manutenção das áreas e dos imóveis melhor qualificados. Outros recursos relevantes podem ser ainda identificados. Nessa parte do procedimento metodológico, será efetuada a investigação de material de planejamento urbano e, principalmente, fontes acadêmicas.

\subsubsection{Quinto procedimento de pesquisa}

O quinto e último procedimento de pesquisa do método de análise da dominação do espaço urbano se dá através de uma investigação dos imóveis estruturadores, de seu poder de atribuição de valor de localização a outros imóveis, e dos fatores de inserção dos imóveis estruturadores na estrutura urbana.

Os imóveis estruturadores mais relevantes podem ser identificados pelo método cartográfico e descritivo. Nessa etapa deverão ser selecionados imóveis estruturadores relevantes de cada período histórico destacado, e serão observados os fatores responsáveis por sua inserção na estrutura urbana. A partir da análise da inserção dos imóveis estruturadores na estrutura urbana, poderão ser destacados os efeitos das forças centrípetas e centrífugas que interferem na dinâmica de estruturação dos imóveis de alto padrão. Com isso, apresenta-se uma ferramenta eficaz para avaliar não apenas o padrão geral de disposição dos imóveis de alto padrão na estrutura urbana, mas também de interpretar variações e permanências em sua dinâmica de desenvolvimento.

Os fatores de inserção dos imóveis de alto padrão na estrutura urbana devem ser investigados, principalmente, com o uso de fontes acadêmicas e material referente ao planejamento urbano, auxiliadas pela interpretação de entrevistas e depoimentos, bem como pelo recurso a fontes jornalísticas e publicitárias.

Todos os cinco procedimentos devem ser aplicados a cada uma das fases da história da cidade investigada, em um recorte temporal delimitado. As fases históricas estabelecidas são referentes às mudanças nos estilos arquitetônicos dos imóveis de alto padrão. Essa divisão de fases arquitetônicas foi efetuada em Goiânia quando da aplicação do método descritivo e cartográfico, que corresponde ao primeiro procedimento empírico da aplicação do método sociológico de análise da dominação do 
espaço urbano. Em Goiânia, o recorte temporal estabelecido compreendeu toda a história da cidade, cujo planejamento e fundação data da era Vargas.

\section{Referências bibliográficas}

ACHCAR, Edy Lamar W. da Silva. Urbanização Corporativa em Goiânia: empreendimentos Louza. Goiânia: dissertação de mestrado em economia, UCG, 2008.

ALVARES, Geraldo Teixeira. A Luta na Epopéia de Goiânia. Rio de Janeiro: Oficina Gráfica do Jornal do Brasil, 1942.

ANDRADE, Luciana Teixeira de "Estilos de Vida nos Condomínios Residenciais Fechados”. In: FRÚGOLI JR, Heitor; ANDRADE, Luciana Teixeira de; PEIXOTO, Fernanda Arêas (orgs.). As Cidades e Seus Agentes: práticas $e$ representações. Belo Horizonte: Editora PUC Minas, 2006.

APPADURAI, Arjun. "Introdução: mercadorias e a política de valor". In: APPADURAI, Arjun (org.). A Vida Social das Coisas: as mercadorias sob uma perspectiva cultural. Niterói: Editora da UFF, 2008.

BADAN, Rosane Costa. "Mobiliário e Decoração". In: LIMA FILHO, Manuel Ferreira; MACHADO, Laís Aparecida (orgs.). Formas e Tempos da Cidade. Goiânia: Editora da UCG, 2007.

BAUDRILLARD, Jean. O Sistema dos Objetos. São Paulo: Perspectiva, 2008.

BERNARDES, Genilda Darc. Construtores de Goiânia: o cotidiano do mundo do trabalho. São Paulo: dissertação de mestrado em sociologia, PUC/SP, 1989.

Goiânia, Cidade Planejada/Cidade Vivida: discurso e cultura da modernidade. Brasília: tese de doutorado em sociologia, UNB, 1998. 
“Considerações Sobre o Plano de Goiânia”. In: SILVA, Luís

Sérgio Duarte da (org.). Relações Cidade-Campo: fonteiras. Goiânia: CEGRAF, 2000.

BERNARDES, Genilda Darc; SOARES Jr., Ademar Azevedo. “Condomínios Horizontais Fechados: reflexão sobre a configuração do espaço intrametropolitano em Goiânia”. In: Revista Sociedade e Cultura- UFG. Goiânia: v. 10, nº 2, 2007.

BOURDIEU, Pierre. O Poder Simbólico. Rio de Janeiro: Bertrand Brasil, 1998.

"Efeitos do Lugar". In: BOURDIEU, Pierre (coord.). A Miséria do Mundo. Petrópolis: Vozes, 1999.

Meditações Pascalianas. São Paulo: Bertrand Brasil, 2001.

As Regras da Arte: gênese e estrutura do campo literário. São Paulo: Companhia das letras, 2002.

A Produção da Crença: contribuição para uma economia dos bens simbólicos. São Paulo: Zouk, 2004.

Coisas Ditas. São Paulo: Brasiliense, 2004 (b).

A Economia das Trocas Simbólicas. São Paulo: Perspectiva, 2005.

A Distinção: crítica social do julgamento. São Paulo: Edusp, 2007.

BURGESS, Ernest W. "O Crescimento da Cidade: introdução a um projeto de pesquisa”. In: PIERSON, Donald (org.). Estudos de Ecologia Humana. São Paulo: Martins, 1970. 
CALDEIRA, Teresa Pires do Rio. Cidade de Muros: crime, segregação e cidadania em São Paulo. São Paulo: Editora 34, 2000.

CAMPOS, Flávia Rezende; MONSUETO, Sandro Eduardo. Distribuição de Renda na Região Metropolitana de Goiânia: os censos de 1991 e 2000 e perspectivas para o novo Censo. Goiânia: NEPEC-UFG, 2010.

CAMPOS, Roberto Cintra. Não Lugares: condomínios horizontais fechados em Goiânia (1990-2006). Porto Alegre: dissertação de mestrado em arquitetura, 2007.

CHAUL, Nasr N. Fayad. A Construção de Goiânia e a Transferência da Capital. Goiânia: Editora da UFG, 1988.

CHAVES, Elza G. De Invasor a Posseiro: estado, igreja e a luta pela terra urbana. João Pessoa: dissertação de mestrado em sociologia, UFPB, 1985.

CORDEIRO, Narcisa Abreu. Goiânia: Evoluções do Plano Urbanístico. Goiânia: Composição Artes Gráficas e Editora, 1990.

CORDEIRO, Narcisa Abreu; QUEIROZ, Normalice Maria. Goiânia: embasamentos do plano urbanístico original. Goiânia: Arte Gráfica, 1989.

CORREA, Elaine Alves Lobo. "Lugares Centrais e Lugares Periféricos de Goiânia: diversidade e complexidade". In: Revista de Geografia da UEL. Londrina: v. 19, n. 2, 2010.

A Formação da Centralidade do Jardim Goiás: Goiânia-GO.

Catalão: texto apresentado ao X EREPEO - Simpósio Regional de Geografia, 2007.

DAHER, Tania. Goiânia: uma utopia européia no Brasil. Goiânia: Instituto Centro-Brasileiro de Cultura, 2003. 
DINIZ, Anamaria. Goiânia de Attilio Corrêa Lima (1932-1935): ideal estético e realidade política. Brasília: dissertação de mestrado em arquitetura e urbanismo, $\mathrm{UNB}, 2007$.

EUFRÁSIO, Mário A. Estrutura Urbana e Ecologia Humana: a escola sociológica de Chicago (1915-1940). São Paulo: Editora 34, 1999.

(introdução à tradução de) HOYT, Homer. "Distorções Recentes dos Modelos Clássicos de Estrutura Urbana”. In: Plural: revista do Departamento de Pós-Graduação em Sociologia da USP. São Paulo: v 15, pp. 129-147, 2008.

Teorias da Estrutura Urbana: textos reunidos de sociologia urbana nos Estados Unidos. São Paulo: NAP-CERU FFLCH USP, 2009.

FERREIRA, João Sette Whitaker. O Mito da Cidade Global: o papel da ideologia na produção do espaço urbano. Petrópolis: Vozes, 2007.

FERREIRA JR, Licídio de Carvalho Bueno. Reflexos do Processo de Ocupação, Apropriação e Uso do Espaço Intra-Urbano em Goiânia: um caso do Setor Bueno. Brasília: dissertação de mestrado em desenvolvimento sustentável, UNB, 2007.

FREHSE, Fraya. "Do Impacto da Modernidade Sobre a Civilidade das Elites nas Ruas de São Paulo no Século XIX”. In: FRÚGOLI JR, Heitor; ANDRADE, Luciana Teixeira de; PEIXOTO, Fernanda Arêas (orgs.). As Cidades e Seus Agentes: práticas e representações. Belo Horizonte: Editora PUC Minas, 2006.

FREHSE, Fraya; LEITE, Rogério Proença. "Perspectivas Teóricas Contemporâneas da Sociologia Brasileira sobre a Cidade: primeiros resultados". In: $33^{\circ}$ Encontro Anual da ANPOCS. São Paulo/Aracaju: GT 01, 2009.

FONSECA, Luciana Nunes. A (Re)Invenção da Ação Coletiva: participação urbana, conflitualidades e segregação sócio-espacial em Goiânia. Brasília: dissertação de mestrado em sociologia, UNB, 2008. 
GRAEF, Edgar Albuquerque. Goiânia: 50 anos. Goiânia: MEC-SESU, 1985.

GRIFFIN, Donald W; PRESTON, Richard E. "Uma Reformulação do Conceito de "Zona de Transição"”. Tradução de Lucimara Flavio dos Reis e Mário A. Eufrásio (2008). Publicado originalmente em: The Annals of theAssociation of American Geographers. Washington: vol. 56, nº 2, pp. 339-350, 1966.

GONÇALVES, Alexandre Ribeiro. A Construção do Espaço Urbano de Goiânia (1933-1968). Goiânia: dissertação de mestrado em história, UFG, 2002.

GUIMARÃES, Cláudia Gomide. Parques Urbanos: sua influência no planejamento e desenvolvimento das cidades. Goiânia: dissertação de mestrado em desenvolvimento e planejamento territorial, UCG, 2010.

HEINZE, Andrew R. "From Scarcity to Abundance: the immigrant as consumer". In: MILLER, Daniel (org.). Consumption: critical concepts in the social sciences. London: Routledge, vol. 2, pp. 55-71, 2004.

HOYT, Homer. The Structure and Growth of Residential Neighborhoods in American Cities. Washington: United States Government Printing Office, 1939.

JABUR, Pedro de Andrade Calil. Brasília: o avesso de uma utopia. Brasília, dissertação de mestrado em sociologia, UNB, 2003.

LEPETIT, Bernard. "Sobre a Escala na História”. In: Revel, Jacques (org.). Jogos de Escalas: a experiência da microanálise. Rio de Janeiro: Editora da FGV, pp. 77-102, 1998.

LIMA FILHO, Manuel Ferreira. "Trilhas Patrimoniais de Goiânia”. In: LIMA FILHO, Manuel Ferreira; MACHADO, Laís Aparecida. Formas e Tempos da Cidade. Goiânia: Editora da UCG, 2007.

MAGNANI, José Guilherme Cantor. "Introdução: circuitos de jovens”. In: MAGNANI, José Guilherme Cantor; SOUZA, Bruna Mantese de. Jovens na Metrópole: etnografias de lazer, encontro e sociabilidade. São Paulo: Terceiro Nome, 2007. 
MAHLER, Christine Ramos; SILVA, Ciro Augusto de Oliveira e. "Conceitos, Estilos e Formas Arquitetônicas”. In: LIMA FILHO, Manuel Ferreira; MACHADO, Laís Aparecida. Formas e Tempos da Cidade. Goiânia: Editora da UCG, 2007.

MANSO, Celina Fernandes Almeida. Goiânia: uma concepção urbana, moderna e contemporânea - um certo olhar. Goiânia: ed. da autora, 2001.

MANSO, Celina Fernandes Almeida; UNES, Wolney. Goiânia Art-Déco: dossiê de tombamento do patrimônio histórico e artístico nacional. Goiânia: IPHANSEPLAM, 2004.

MARINHO, Clorisnete Borges. "Região Sul de Goiânia: um lugar valorizado na metrópole". In: Revista GEOUSP - Espaço Tempo. São Paulo: n. 19, pp. 113-129, 2006.

MARTINS, Rubia Nara Silvia. "A Dinâmica dos Bairros de Goiânia como Apoio ao Estudo do Crescimento Urbano do Município". In: Anais do XVI Encontro Nacional dos Geógrafos. Porto alegre, 2010.

MEDEIROS, Wilton de Araújo. “As Duas Cidades”. In: Sociedade e Cultura. Goiânia: v.5, n.2, pp. 163-170, 2002.

“Goiânia de Ontem nos Mapas de Memória". In: LIMA FILHO, Manuel Ferreira; MACHADO, Laís Aparecida. Formas e Tempos da Cidade. Goiânia: Editora da UCG, 2007.

Goiânia Metrópole: sonho, vigília e despertar (1933-1973).

Goiânia: tese de doutorado em história, UFG, 2010.

MICELI, Sergio. "Bourdieu e a renovação da sociologia contemporânea da cultura”. In: Tempo Social. São Paulo: v.15, n.1, PP, 63-79, 2003. 
MONTEIRO, Ofélia Sócrates do Nascimento. Como Nasceu Goiânia. São Paulo: Empresa Gráfica da Revista dos Tribunais, 1938.

MORAES, Sérgio. O Empreendedor Imobiliário e o Estado: o processo de expansão de Goiânia em direção sul (1975-1985). Brasília: dissertação de mestrado em planejamento urbano, UNB, 1991.

MOTA, Juliana Costa. Planos Diretores de Goiânia, Década de 60: a inserção dos arquitetos Luís Saia e Jorge Wilhein no campo do planejamento urbano. São Carlos: dissertação de mestrado em arquitetura e urbanismo, USP, 2004.

MOURA, Cristina Patriota de. Ilhas Urbanas: novas visões do paraíso. Rio de Janeiro: tese de doutorado em antropologia social, UFRJ, 2003.

MOURA, Gerusa Gonçalves. Condomínios Horizontais/Loteamentos Fechados e a Vizinhança (In)Desejada: um estudo em Uberlândia/MG. Uberlândia: tese de doutorado em geografia, UFU, 2008.

MOYSÉS, Aristides. Estado e Urbanização: conflitos sociais na região noroeste de Goiânia (década de 80). São Paulo: dissertação de mestrado em ciências sociais. PUC-SP, 1996.

MOYSÉS, Aristides; BORGES, Elcileni de Melo. A Negação do Lugar e a Recriação da Cidade: condomínios horizontais fechados na metrópole goianiense. Goiânia: SEPLAM, 2009.

MOYSÉS, Aristides; BORGES, Elcileni de Melo. Dinâmica Imobiliária e a Nova Paisagem da Região Metropolitana de Goiânia: o impacto da produção de alto nível. Texto Apresentado ao XIII Encontro Nacional da ANPUR. Florianópolis: 2009.

MURPHY, Raymond E.; VANCE, J. E. "Delimiting the CBD”. In: Economic Geographer. Worcester: vol. 30, n. 3, pp. 189-222, 1954. 
“A Comparative Study of Nine Central Business Districts". In:

Economic Geographer. Worcester: vol. 30, n. 4, pp. 301-336, 1954.

NUNES, Heliane Prudente. "Os Imigrantes Árabes em Goiânia”. In: LIMA FILHO, Manuel Ferreira; MACHADO, Laís Aparecida. Formas e Tempos da Cidade. Goiânia: Editora da UCG, 2007.

OLIVEIRA, Eliézer Cardoso de. Imagens e Mudança Cultural em Goiânia. Goiânia: dissertação de mestrado em sociologia, UFG, 1999.

OLIVEIRA, Maria das Mercedes Brandão de. "O Padrão Territorial de Goiânia: um olhar sobre o processo de formação de sua estrutura urbana". In: Arquitextos: revista online de arquitetura e urbanismo. 065.07, 2006. Disponível em http://www.vitruvius.com.br/revistas/browse/arquitextos. Acessado em maio de 2012.

OLIVEIRA E SILVA, Ciro Augusto de. Revitalização e Preservação do Patrimônio Histórico e Urbanístico de Goiânia. Goiânia: dissertação de mestrado em gestão do patrimônio cultural, UCG, 2006.

PRESTON, Richard E. "The Zone in Transition: a study of urban land use patterns". In: Economic Geography. Worcester: vol. 42, n. 3, pp. 236-260, 1966.

"A Detailed Comparison of Land Use in Three Transition Zones" In: Annals of the Association of American Geographers. Washington: vol. 58, n. 3, pp.461-484, 1968.

REVEL, Jacques. "Microanálise e Construção do Social”. In: Revel, Jacques (org.). Jogos de Escalas: a experiência da microanálise. Rio de Janeiro: Editora da FGV, pp. 15-38, 1998.

ROZEMBAUM, Sérgio; MACEDO-SOARES, T. Diana. L. v. A. "Proposta para a Construção de um Índice Local de Preços de Imóveis a partir de Lançamentos Imobiliários de Condomínios Residenciais”. In: RAP. Rio de Janeiro: n.41(6), PP. 10691094, 2007. 
SAHLINS, Marshall D. Cultura e Razão Prática. Rio de Janeiro: Zahar, 2003.

SANTANA, Francis Marques Otto de Camargo; BONETTI, Maria Cristina de Freitas; MACÊDO, Maurides. "Pioneiros: compondo o passado". In: LIMA FILHO, Manuel Ferreira; MACHADO, Laís Aparecida. Formas e Tempos da Cidade. Goiânia: Editora da UCG, 2007.

SILVA, Rosana Fernandes da. Condomínios Horizontais Fechados em Goiânia: o caso do Privê Atlântico. Goiânia: dissertação de mestrado em sociologia, UFG, 2003.

SILVA NETO, Eurípedes Afonso da. Goiânia Casa Moderna. Brasília: dissertação de mestrado em arquitetura e urbanismo, UNB, 2010.

SIMMEL, Georg. "A Metrópole e a Vida Mental”. In: VELHO, Otávio Guilherme (org.). O Fenômeno Urbano. Rio de Janeiro: Zahar, 1967.

"Da Psicologia da Moda: um estudo sociológico". In: SOUZA, Jessé; OËLZE, Berthold (orgs.). Simmel e a Modernidade. Brasília: Editora da UnB, 1998.

SOUZA, Jessé. "Introdução". In: SOUZA, Jessé; OËLZE, Berthold (orgs.). Simmel e a Modernidade. Brasília: Editora da UnB, 1998.

TELLES, Vera da Silva. "Trajetórias Urbanas: fios de uma descrição da cidade". In: TELLES, Vera da Silva; CABANES, Robert (orgs.). Nas Tramas da Cidade: trajetórias urbanas e seus territórios. São Paulo: Humanitas, 2006.

VAZ, Maria Diva de Araújo Coelho. Transformação do centro de Goiânia: renovação ou reestruturação? Goiânia: dissertação de mestrado em geografia, UFG, 2003. 
VEIGA FILHO, Ary Alencastro. Avenida Goiás: dinâmica de ocupação. Brasília: dissertação de mestrado em arquitetura e urbanismo, UNB, 2010.

VILLAÇA, Flávio. Espaço Intra-Urbano no Brasil. São Paulo: Studio Nobel, Fapesp- Lincoln Institute, 2001.

"São Paulo: segregação urbana e desigualdade". In: Estudos Avançados. São Paulo: n. 25 (71), PP. 37-58, 2011.

WILK, Richard R. "Houses as Consumer Goods: social processes and allocation decisions". In: MILLER, Daniel (org.). Consumption: critical concepts in the social sciences. London: Routledge, vol. 2, pp. 133-154, 2004.

WITTGENSTEIN, Ludwig. The Blue and Brown Books: preliminary studies for the 'Philosophical Investigations'. New York: Harper, 1965.

ZUKIN, Sharon. "Gentrification and Cuisine". In: MILLER, Daniel (org.). Consumption: critical concepts in the social sciences. London: Routledge, vol. 3, pp. 418-439, 2004.

\section{Apêndice: atividades de pesquisa}

\section{Pesquisa bibliográfica}

A pesquisa bibliográfica foi de importância fundamental para essa pesquisa, tanto no que diz respeito ao referencial teórico-metodológico, quanto no que diz respeito à pesquisa empírica, que dependeu em grande parte do material obtido em fontes acadêmicas. 


\section{Pesquisa em arquivos}

- Arquivo da SEPLAM (Secretaria Municipal de Planejamento da Cidade de Goiânia).

- Arquivo do IBGE (Instituto Brasileiro de Geografia e Estatística).

- Arquivo da ADEMI-GO (Associação das Empresas do Mercado Imobiliário de Goiás).

- Arquivo do Museu Pedro Ludovico.

- Biblioteca do Departamento de Arquitetura da PUC-GO.

- Biblioteca Central da UFG.

A SEPLAM possui farta documentação, contando com: mapas diversos; um grande acervo de fotografias aéreas e de satélite que cobre toda a história da cidade; as pastas de bairros, que contém documentação diversa, além de fotografias de diferentes épocas e recortes jornalísticos; todos os planos diretores da cidade impressos na íntegra; plantas de bairros e de edifícios; um vasto acervo de fotografias históricas; grande quantidade de relatórios com dados estatísticos de diferentes períodos, levantados pelo IBGE e pela própria instituição; além de uma biblioteca especializada em Goiânia, com obras acadêmicas, jornais e revistas. A ADEMI, por sua vez, possui pesquisas de lançamentos imobiliários que não foram ainda fotografadas na íntegra. Essas pesquisas fornecem dados diversos sobre lançamentos imobiliários e cobrem um período entre o início da década de 90 e os dias atuais. Material relevante também foi encontrado no arquivo do Departamento de Arquitetura da PUC-GO.

\section{Atividades de campo}

- Visitas a pontos de interesse com registro fotográfico e eventuais trajetos de caminhada. Os locais visitados foram orientados através da leitura de fontes de pesquisa ou da análise de fotos aéreas e de satélite, e assim foram listados para a visitação quando da ida em campo. Quando houve oportunidade, consultas informais foram efetuadas com pessoas encontradas durante a visita.

- Entrevistas gravadas. Foram gravadas entrevistas com um corretor imobiliário especializado em residências localizadas em condomínios fechados (Juliano Benetti), com um corretor não especializado (Watson Dias), com um avaliador de imóveis da Caixa Econômica Federal (Roberto Franco) e com dois casais, 
ambos recém-casados e que se mudaram recentemente. $\mathrm{O}$ primeiro dos casais se mudou para um condomínio fechado de alto padrão (Bruno e Juliana), o segundo para um apartamento de padrão médio (Lázaro e Tatiana), situado em um bairro adjacente ao setor de imóveis de alto padrão de Goiânia. Além disso, foi permitida a gravação de conversas informais sobre assuntos ligados ao meu objeto, travadas com um casal residente em um condomínio fechado de alto padrão em companhia de um engenheiro especializado na construção de residências de alto padrão em condomínios fechados; com outro casal residente em um condomínio fechado de alto padrão; com um morador de uma residência de alto padrão construída na década de 80 , situada uma em área atualmente em verticalização; e com um morador da cidade que habitava uma residência de alto padrão na década de 70.

\section{Atividades de gabinete}

- Análise da publicação bienal Sociedade Goiana, do colunista social Arthur Resende, publicada a partir de 1991. A publicação apresenta nomes de centenas de integrantes da "sociedade goiana", com séries de dados que incluem o local de trabalho dessas pessoas e, na maioria dos casos, o local de moradia.

- Pesquisa na internet. A pesquisa na internet se fez principalmente de três modos, orientados pelos procedimentos de pesquisa adotados: a pesquisa de valores de mercado e de tipos imobiliários, a pesquisa de categorias discursivas e a pesquisa de localização e análise de elementos urbanos. No primeiro caso, foram realizadas pesquisas em sites e blogs imobiliários. No segundo caso, foram realizadas pesquisas de material discursivo diverso (textos jornalísticos, anúncios publicitários, textos de blogs e de sites especializados). No terceiro caso, são utilizadas as ferramentas do Google Earth, do Google Maps e do Wikimapia, além de sites específicos de lançamentos imobiliários, os hot-sites, e de sites como o da Veja Goiânia, que lista e classifica restaurantes, bares e outras atividades.

- Análise de documentação coletada e dos dados obtidos em arquivos e em campo 
- Análise específica da coleção de fotografias aéreas obtida no arquivo da SEPLAM

- Análise específica das pesquisas de lançamentos imobiliários obtidas no arquivo da ADEMI

- Cruzamento de dados e confecção de mapas

Analisei grande parte da documentação coletada e dos dados obtidos em arquivos, com o cruzamento dos dados e a confecção de mapas, de acordo com os procedimentos de pesquisa adotados. $\mathrm{O}$ processo se encontra ainda em andamento e deverá seguir o desenvolvimento da pesquisa até sua apresentação final no doutorado. Como documentação coletada, foi acumulado material bastante considerável, que pode ser dividido em: material fotográfico, material jornalístico, material publicitário, dados estatísticos, dados das pesquisas de lançamentos da ADEMI, planos diretores, dados de publicações e guias institucionais e de consumo, dados de localização e preço de imóveis, revistas imobiliárias coletadas, dados das pesquisas imobiliárias do CRECIGO e mapas diversos. 